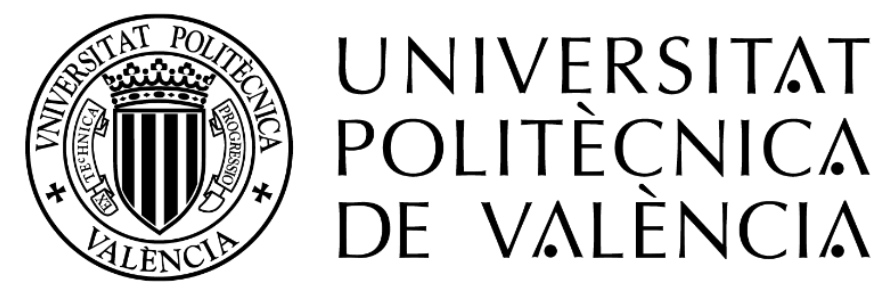

Ph.D. Thesis

Evaluation of false positive results in microbial inhibitor tests for screening antibiotics in goat milk

Tamara Romero Rueda

Supervisors:

Dr. Ma Pilar Molina Pons

Dr. Mª Carmen Beltrán Martínez

Dr. Wim Reybroeck

Valencia, March 2015 



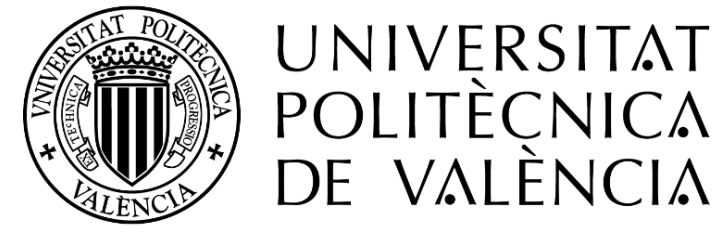

Ph.D. Thesis

\title{
Evaluation of false positive results in microbial inhibitor tests for screening antibiotics in goat milk
}

\section{Evaluación de resultados falsos positivos en los métodos microbiológicos de detección de antibióticos en leche de cabra}

Tamara Romero Rueda

\author{
Supervisors: \\ Dr. Mㄹ Pilar Molina Pons \\ Dr. Mํㅡㄹ Carmen Beltrán Martínez \\ Dr. Wim Reybroeck
}

March 2015

Departamento de Ciencia Animal Instituto de Ciencia y Tecnología Animal

Universitat Politècnica de València

This research forms part of the Project AGL2009-11524 financed by the Ministerio de

Ciencia e Innovación (Madrid, Spain) 



\section{Evaluation of false positive results in microbial inhibitor tests for screening antibiotics in goat milk}

This Thesis has been submitted in fulfilment of the requirements for the degree of Doctor with International Mention at the Universitat Politècnica de València.

Esta tesis ha sido escrita y presentada como uno de los requisitos para optar al grado de Doctor con Mención Internacional por la Universitat Politècnica de València.

By: Tamara Romero Rueda

Valencia, March 2015 

Just don't give up trying to do what you really want to do. Where there is love and inspiration, I don't think you can go wrong.

Ella Jane Fitzgerald 
La cabra siempre tira al monte 


\section{Agradecimientos}

Antes de empezar con los agradecimientos me gustaría pedir disculpas a todos aquellos que pueda olvidarme de mencionar en estas líneas, ya que hay mucha gente que ha podido ayudarme de forma directa o indirecta en que el esfuerzo realizado durante estos cuatro años y medio haya dado su fruto, así que ... a todos ellos decirles, iiii GRACIAS \&) !!!!

Dicho lo cual empezaré los agradecimientos y para no liarme iré uno detrás de otro.

En primer lugar me gustaría dar las gracias a mis tres directores de la tesis. A Pilar Molina, (jefa suprema) por darme la oportunidad de poder realizar la tesis y por el apoyo, confianza y dedicación que has depositado en mí durante todos estos años. A Mํa Carmen Beltrán (mi segunda jefa) por estar siempre a mi lado ayudándome en todo momento, en especial cuando empecé en este mundo de los métodos de detección de antibióticos que iba un poco perdida. Wim Reybroeck (mijn Belgische promotor, the Belgian boss) wil ik hartelijk bedanken in de eerste plaats om mij de kans te geven gedurende 5 maanden ervaring op te doen in zijn labo (ILVO, Melle). Door deze stage heb ik niet alleen nieuwe methodes aangeleerd, maar kreeg ik ook de mogelijkheid deze toe te passen, wat resulteerde tot een volledig hoofdstuk van dit doctoraat. Daarnaast wil ik hem eveneens bedanken voor zijn steun en vertrouwen, en om mij te behandelen als 'eentje meer' van het labo QAAB. Sin vosotros no hubiera podido ser posible. Zonder jullie zou dit niet mogelijk geweest zijn.

Quisiera agradecer a Rafael Althaus su ayuda en los análisis estadísticos de esta tesis. También, darle las gracias por amenizar las horas de la comida junto a Pepo en sus viajes al departamento y por decirme cosas bonitas como "Tarsana" o "Multipropósito".

A Ana Molina y a $\mathrm{M}^{\mathrm{a}}$ Isabel Berruga de la Universidad de Castilla-La Mancha gracias por su participación en este proyecto.

A mi compi Mileta o también conocida como "Miraculosa" que empezamos juntas la carrera y quien nos iba a decir en esa época que acabaríamos haciendo la tesis en el mismo grupo de trabajo y trabajando juntas. Muchas gracias por estar siempre ahí y que se te echa de menos.

Gracias por el apoyo técnico recibido a todos los fabricantes y distribuidores de los métodos microbiológicos de cribado empleados durante la fase experimental de esta tesis.

Ahora tengo que darle las gracias a lon al que considero como mi hermano en muchas ocasiones y no es porque cada dos por tres discutamos sino porque le tengo mucho aprecio. Aunque parezca mentira si no fuera por él hoy en día no me encontraría escribiendo los 
agradecimientos de la tesis. Todo esto se remonta a diciembre del 2009 cuando defendimos las tesinas de Máster en el departamento que se acercó Pilar Molina para decirme si estaba interesada en hacer la tesis doctoral, yo le dije que no que estaba trabajando de ingeniera que la verdad estaba muy bien y que no me interesaba. Pero, lon no sé si por el hecho de tenerme cerca ya que como dice le molo, jajajaja, le llamó a mi padre para decirle que iba a perder una oportunidad y que no sabía lo que hacía. Y claro mi padre como no, me llamó y me dijo que presentara los papeles de la beca que era una oportunidad muy buena para mí que nunca sabes lo que puede pasar... ¿Y que pasó? que me concedieron la beca y hoy estoy aquí y el mundo no se ha acabado a pesar de las predicciones de lon.

Ahora le toca el turno a toda la gente del despacho donde escribí la tesis, Emilio José, Martita, Alicia, Carlicos, y Jorge gracias por vuestra compañía y por todos los momentos que hemos pasado juntos. También dar las gracias a toda la gente que ha pasado por allí: Carlos (Txarly), Julito, el niño de las flores, Renato, Ángel Sánchez Quinche...

No puedo olvidarme de Martín Rodríguez y Cristòfol Peris que me han hecho compañía hasta altas horas de la noche y fines de semana inclusive, que siempre se han preocupado por mí, me han dado ánimos y aclarado cualquier duda durante este tiempo. No puc oblidarme de Martín Rodríguez i Cristòfol Peris que m'han fet companyia fins a altes hores de la nit i caps de setmana inclosos, que sempre s'han preocupat per mi, m'han donat ànims i aclarit qualsevol dubte durant aquest temps.

Agradecer también a toda la gente del departamento de ciencia animal en especial a la planta de producción y a mis compañeros de granjas Josevi y Joselu, a lon ya no le digo nada, por ayudarme a realizar mis experimentos en la granja.

Ik had graag alle mensen van het ILVO bedankt die mijn Belgische stage zo aangenaam hebben gemaakt. Vooral een grote dankjewel aan mijn collegaatjes van het labo QAAB: Katleen, Martine, Eline, Anna, Annelies, Christa, Veroniek de Paepe, Veronique Ottoy, en Sigrid. Door hen voelde ik mij thuis en eentje van hen. ¡Guapas, merci!

Quiero recordar también a los estudiantes/amigos que realizaron sus proyectos de fin de carrera conmigo Sergio Vivó, María Mora, Aroa Conde y Marcos Val. Su trabajo también ha sido importante para que esta tesis haya llegado a buen puerto.

Antes de terminar con la gente de la universidad me gustaría agradecer al Dr. Octopus, conocido como Pablete, las risas que nos echábamos cada vez que nos cruzábamos por las escaleras y me recordaba la Guirra y el oso negro. 
Bueno que decirles a mis 2 mejores amigas Goñi y Plazas (Ana \& Anna) que durante estos 4 años creo que no me han escuchado mucho de que iba mi tesis porque se pensaban que la había hecho con ovejas en vez de con cabras, jajajajajaja pero yo las quiero igual. Muchas gracias por estar siempre a mi lado para todo, tanto en las cosas buenas como en las malas. "Amigas somos, amigas seremos y como cabras siempre estaremos" eso que no se os olvide (3 nosonmultitud). También darles las gracias a Christian y Gabriela por tener la paciencia de aguantar a mis amigas y a mí.

Gracias a todos mis amigos que siempre están ahí cuando los he necesitado Pepa y Agus, los mareados Nacho y Sofía, todos los de ludic (Maribel, Carolina, Javi, Tere, Imna, Jordi, Diego, Sergio...), la gente del baloncesto, a mi super equipo que me ha acogido otra vez este año y a mi gata preferida Pirito.

A mi amiga Nikki o Nikkita como yo le llamo gracias por ser un apoyo incondicional durante mi estancia en Bélgica, por las tardes y los fines de semana que hemos pasado juntas cada una en su laboratorio. Quien me iba a decir a mí que en ILVO habría una chica tan maja que hiciera el doctorado y que tuviera un novio de Mislata e incluso que tuviéramos amigos en común.

Como se suele decir lo bueno siempre se deja para el final. Por lo que le ha llegado el turno de agradecerle a mi familia por un lado a mi padre, Emilia y mi hermano y por otro a mi madre y mi abuela toda la comprensión y apoyo que he recibido, ya que en muchas ocasiones he pasado más tiempo en el departamento que con ellos. Decirles gracias también por enseñarme a trabajar duro y esforzarme siempre al máximo en lo que hago.

Y a ti Carles, mi piñita, gracias por estar a mi lado a lo largo de toda la tesis y en especial por aguantarme los últimos meses, ya que había días que no me aguantaba ni yo, sé que ha sido difícil pero ahora toca disfrutar los dos, así que ¡¡GRACIAS!!

iiiMuchas gracias a todos de verdad!!! 



\section{Summary}

Goat milk is primarily destined for the production of fermented products, in particular cheese. Therefore, the control of antibiotic residues in milk is of great importance, since these could have negative repercussions on technological properties of the milk as well as on the health of consumers.

In milk quality control programs, microbial inhibitor tests are widely applied to detect antibiotics during the screening stage. However, tests are non-specific and may be affected by substances other than antimicrobials which could inhibit the growth of the test microorganism, causing false positive results.

The aim of this thesis was to evaluate the interference, related to the presence of different contaminants in goat milk, on the response of microbial inhibitor tests commonly used in Spain to detect antibiotics (BRT MRL, Delvotest SP-NT MCS and Eclipse 100 tests). The influence of the physicochemical characteristics of goat milk on the false positive outcomes in microbial screening tests was also investigated.

The suitability of microbial inhibitor tests for screening antibiotics in colostrum secretions was studied by analysing antibiotic-free colostrum and milk samples from forty-three MurcianoGranadina goats, collected every 12 hours during the first week post-partum. Microbial inhibitor tests were not suitable for the analysis of goat colostrum because they presented a high percentage of doubtful and positive results (up $37.2 \%$ in the 36 hours after partum).

To evaluate the effect of caprine colostrum on the microbial test response, antimicrobial-free goat milk spiked with different concentrations of colostrum was analysed to calculate the inhibitory concentrations producing $5 \%$ of positive results. The highest interferences were obtained for the addition of colostrum from 12 to 24 hours post-partum and the colostrum concentrations producing $5 \%$ positive results were between 5.1 and $34.6 \%$. The BRT MRL was the test the most affected.

In another study, the interference of detergents and disinfectants used for the cleaning of milking equipment and milk storage tanks of dairy farms was investigated. Antimicrobial-free goat milk was spiked with eight concentrations of different cleaning products ( 5 acid, 5 alkaline, 5 domestic washing-up liquids, and 1 disinfectant) and analysed using microbial screening tests. The presence of acid detergent and disinfectant based on sodium hypochlorite in goat milk did not affect the microbial test response. However, alkaline detergents at concentrations $\geq 1 \mathrm{ml} / \mathrm{l}$ could lead to false positive results in microbial inhibitor tests (up to $16.7 \%$ ) and from $4 \mathrm{ml} / \mathrm{l}$ on $100 \%$ positive results were obtained. Regarding the 
products used for home use, and those used on farms and small size dairies, washing-up liquid containing sodium laureth sulphate and ethanol had the greatest effects on microbial inhibitor tests, even starting from a relatively low concentration $(1 \mathrm{ml} / \mathrm{l})$. On the other hand, the presence of a relatively low concentration of detergents in goat milk $(0.5 \mathrm{ml} / \mathrm{l})$ slightly modified the detection capability of the microbial inhibitor tests for amoxicillin, ampicillin, benzylpenicillin, and cloxacillin, although the detection of these drugs at MRL (safe level) was not compromised.

Antiparasitic agent residues in goat milk could be another possible cause of false positive results in microbial screening tests. An in vitro study to evaluate the effect of seven parasiticides commonly used in dairy goats was carried out. Further two studies, where albendazole and ivermectin were applied to two groups of dairy goats in lactation were performed. It should be noted that the parasiticide ivermectin is banned for the treatment of animals producing milk for human consumption, although its inclusion in this study was considered interesting to understand the potential effect of their residues in milk, in the event the practice was performed illegally.

In the in vitro study, raw antibiotic-free milk from goats was spiked individually with eight different concentrations of albendazole, closantel, diclazuril, febendazole, levamisole, diazinon, and ivermectin. The microbial inhibitor test results showed a great variability according to the test and the drug under study. Of the tests considered, the BRT MRL test was the most sensitive to antiparasitic agents, with the lowest concentrations of antiparasitic agent causing 5,10 , and $50 \%$ of positive results. Generally, closantel and diazinon were the antiparasitic agents that produced higher interferences in all tests, since low concentrations already resulted in positive results, while only higher concentrations of diclazuril and ivermectin showed an inhibitory effect.

To evaluate the effect of albendazole residues on the microbial inhibitor test response, eighteen healthy Murciano-Granadina goats in mid-lactation were treated with a single oral administration of the commercially available albendazole registered for dairy sheep $(7.5 \mathrm{mg} / \mathrm{kg}$ b.w. of active compound) with a withdrawal period of 4 days for milk production in ovine. Albendazole and its metabolite residues in goat milk after under cascade treatment were not detected above MRL from the third day post-administration. However, a high occurrence of non-compliant results was obtained for the BRT MRL test during the first six days after treatment, suggesting that factors related to the albendazole application other than the drug concentration are able to affect the microbial inhibitor test response in some cases. 
Regarding the ivermectin study, twenty-eight Murciano-Granadina goats infested with Sarcoptes scabiei var. caprae were treated with a subcutaneous injection of ivermectin (200 $\mu \mathrm{g} / \mathrm{kg}$ b.w.), with a second dose applied seven days after the first treatment. Drug residues in goat milk were recorded during the first fifteen days of the experiment with concentrations ranging from 8.13 to $24.25 \mathrm{ng} / \mathrm{ml}$. In addition, all the microbial screening tests seem to be affected by the ivermectin treatment, with BRT MRL the most affected (20\%) compared with Delvotest SP-NT MCS and Eclipse 100 (6.6 and 5.7\%, respectively). These positive results cannot be associated with the ivermectin concentration in goat milk, as the concentrations measured were lower than the inhibitory concentrations as reported in a previous in vitro study for these microbial tests. Thus, as suggested by some authors, interferences could be related to changes or alterations caused by the application of the parasiticide agent or by the parasitic disease itself, which could affect the immune response of the animals favouring the presence of inhibitory substances in milk.

The study of the effect of the goat milk composition on the specificity (rate of false positive results) of microbial inhibitor tests for screening antibiotics was also considered. Thus, individual goat milk samples $(n=200)$ were analysed by microbial inhibitor tests using both visual and instrumental classification of the test results. The highest specificity values were obtained for the instrumental interpretation of the test results $(94-99 \%$ vs $90-96 \%)$ due to the occurrence of samples with intermediate colorations (green-yellow, yellow-blue) making the visual classification more difficult and subjective. A relation was found between positive results in BRT MRL and Eclipse 100 tests and an elevated fat content in the goat milk. Positive outcomes in Eclipse 100 were associated with the butyric acid concentration in the milk. Further, the Delvotest SP-NT MCS test response was affected by elevated $\mathrm{pH}$ values, high lactoferrrin and myristoleic acid concentrations in the goat milk. This percentage of positive results could be minimized by a pre-treatment prior to microbial inhibitor test analysis, such as fat removal by centrifugation $\left(3,100 \mathrm{~g}\right.$ for $10 \mathrm{~min}$ at $\left.4{ }^{\circ} \mathrm{C}\right)$ and/or heating (80 ${ }^{\circ} \mathrm{C}$ for $\left.10 \mathrm{~min}\right)$.

Undoubtedly, improvements on the specificity of the microbial inhibitor tests for screening antibiotics in goat milk are desirable to avoid the destruction of milk compliant for human due to the occurrence of false positive results. The related financial losses affect farmers and dairies. However, it should be noted that the presence of contaminants in goat milk could be avoided by applying good farming practices designed to ensure that milk is obtained from healthy animals under proper hygienic conditions so ensuring the food safety of goat milk and related dairy products. 



\section{Resumen}

La leche de cabra se destina fundamentalmente a la fabricación de productos fermentados, en especial diferentes tipos de queso. Por lo tanto, el control de residuos de antibióticos en la leche es de gran importancia, ya que su presencia podría tener repercusiones negativas sobre las propiedades tecnológicas de la leche, así como en la salud de los consumidores.

En los programas de control de la calidad de la leche los métodos microbiológicos son ampliamente utilizados para la detección de antibióticos en la etapa de cribado. Sin embargo, debido a que son métodos inespecíficos, otras sustancias distintas a los antibióticos pueden ser capaces de inhibir el crecimiento del microorganismo del método ocasionando resultados falsos positivos.

El objetivo de esta tesis ha sido evaluar las interferencias relacionadas con la presencia de diferentes sustancias contaminantes de la leche de cabra, sobre la respuesta de los métodos microbiológicos más empleados para la detección antibióticos en España (BRT MRL, Delvotest SP-NT MCS y Eclipse 100). También, se ha estudiado la influencia de las características físico-químicas de la leche de cabra sobre los resultados falsos positivos de estos métodos.

La idoneidad de los métodos microbiológicos para la detección de antibióticos en las secreciones calostrales se estudió mediante el análisis de muestras de calostro y de leche procedentes de cuarenta y tres cabras de raza Murciano-Granadina obtenidas cada 12 horas durante la primera semana post-parto. Los resultados indicaron que los métodos microbiológicos no son adecuados para el análisis del calostro caprino, ya que se encontraron elevados porcentajes de resultados dudosos y positivos (hasta un $37,2 \%$ a las 36 horas después del parto).

Para evaluar el efecto de la mezcla de calostro en la leche de cabra sobre la respuesta de los métodos de cribado, se analizaron muestras de leche de cabra sin antibióticos con diferentes concentraciones de calostro. Las mayores interferencias se obtuvieron con la adición del calostro obtenido a las 12 y 24 horas después del parto, siendo el método BRT LMR el más afectado. También se calcularon las concentraciones inhibitorias de calostro que producen el $5 \%$ de resultados positivos en los métodos microbiológicos, estando comprendidas entre 5,1 y $34,6 \%$.

En otro estudio, se investigó la interferencia que producen en los métodos microbiológicos los detergentes y desinfectantes empleados en las explotaciones ganaderas para la limpieza del material de ordeño y tanques de almacenamiento de la leche. Para ello, se adicionaron 
ocho concentraciones de diferentes productos de limpieza (5 ácidos, 5 alcalinos, 5 lavavajillas de uso doméstico y 1 desinfectante) a leche de cabra sin antibióticos, y se analizaron mediante los métodos microbiológicos de detección de antibióticos. La presencia de detergentes ácidos y de desinfectante, cuya composición se basa en hipoclorito sódico, en la leche de cabra no afectó a la respuesta de los métodos. Por el contrario, los detergentes alcalinos en concentraciones $\geq 1 \mathrm{ml} / \mathrm{l}$ dieron lugar a resultados falsos positivos en las pruebas microbianas (hasta un 16,7\%) y a concentraciones de $4 \mathrm{ml} / \mathrm{l}$ el 100\% de las respuestas obtenidas fueron positivas. En cuanto a los productos de limpieza de uso doméstico, que se suelen emplear en pequeñas granjas y queserías, el lavavajillas que contiene lauril sulfato sódico y etanol, presentó un mayor efecto que el resto de productos ensayados sobre los métodos microbiológicos, incluso a concentraciones relativamente bajas $(1 \mathrm{ml} / \mathrm{l})$. Además, la presencia en la leche de cabra de detergentes a bajas concentraciones $(0,5 \mathrm{ml} / \mathrm{l})$ modificó ligeramente la sensibilidad de los métodos microbiológicos para la amoxicilina, ampicilina, bencilpenicilina y cloxacilina, aunque no compromete la detección de estos antibióticos a los límites de seguridad (LMR).

Los residuos de antiparasitarios en la leche de cabra podrían ser otra de las posibles causas de resultados falsos positivos en las pruebas de detección de inhibidores. Para su estudio se realizó un experimento in vitro para evaluar el efecto de siete antiparasitarios de uso frecuente en ganado caprino lechero, así como, dos experimentos en los cuales diferentes grupos de cabras en lactación se trataron con albendazol e ivermectina. Hay que señalar que, auque la ivermectina está prohibida en el tratamiento de animales productores de leche para consumo humano, aunque se consideró interesante su inclusión en este estudio para analizar el potencial efecto de sus residuos en la leche en caso de una aplicación ilegal.

En el estudio in vitro, se añadieron ocho concentraciones diferentes de albendazol, closantel, diclazurilo, febendazol, levamisol, diazinón e ivermectina a leche cruda de cabra sin antibióticos. Los resultados mostraron una gran variabilidad según el método y antiparasitario empleado. El método BRT MRL fue el más sensible frente a los agentes antiparasitarios, ya que presentó concentraciones inhibidoras más bajas que produjeron un 5,10 y $50 \%$ de resultados positivos en comparación con los otros métodos. En general, los antiparasitarios closantel y diazinón fueron los que produjeron mayores interferencias en todos los métodos de cribado a concentraciones relativamente bajas. Por el contrario, se necesitaron concentraciones más elevadas de levamisol e ivermectina para ocasionar resultados falsos positivos en las pruebas microbianas de control. 
Para evaluar el efecto de los residuos de albendazol sobre la respuesta de los métodos microbiológicos, se emplearon dieciocho cabras Murciano-Granadinas en mitad de lactación tratadas con una única dosis oral de albendazol (7,5 mg/kg de principio activo por peso vivo) comercialmente registrado para ovejas lecheras que presenta un período de eliminación de 4 días. Tanto el albendazol como sus metabolitos no se detectaron por encima del límite máximo de residuos a partir del tercer día del tratamiento. Sin embargo, el método BRT MRL mostró una alta frecuencia de resultados falsos positivos durante los seis días después de la administración, lo que sugiere que otros factores relacionados con la aplicación del antiparasitario diferentes a la concentración de albendazol son capaces en algunos casos de influir sobre la respuesta de los métodos de detección de inhibidores.

En cuanto al estudio de la ivermectina, veintiocho cabras Murciano-Granadinas infestadas por Sarcoptes scabiei var. caprae fueron tratadas con una dosis de ivermectina por vía subcutánea (200 mg/kg de peso vivo), que se repitió a los siete días después de la primera administración. Los residuos de este antiparasitario en leche de cabra se detectaron durante los quince días del experimento a concentraciones comprendidas entre 8,13 y $24,25 \mathrm{ng} / \mathrm{ml}$. Además, todos los métodos de cribado presentaron resultados positivos durante el experimento, siendo el BRT MRL el método que presentó un mayor porcentaje (20\%) en comparación con el Delvotest SP-NT MCS (6,6\%) y el Eclipse 100 (5,7\%). Estos resultados positivos no se pueden asociar exclusivamente con la concentración de ivermectina en la leche de cabra, ya que las concentraciones inhibitorias calculadas en un estudio in vitro previo fueron muy superiores a las cuantificadas en la leche de cabras tratadas con ivermectina. Por lo que, las interferencias encontradas podrían estar relacionados con cambios o alteraciones causados por la aplicación del antiparasitario o por la propia enfermedad, que podrían afectar la respuesta inmune de los animales favoreciendo la presencia de sustancias inhibidoras en la leche.

También, se planteó realizar el estudio del efecto de la composición de la leche de cabra sobre la selectividad (resultados falsos positivos) de los métodos microbiológicos. Para ello, se analizaron 200 muestras de leche de cabra individuales mediante los métodos microbiológicos clasificando los resultados de modo visual e instrumental. La selectividad más elevada se obtuvo con la interpretación instrumental respecto a la visual (94-99\% vs 90$96 \%$ ), ya que las muestras con coloraciones intermedias (verde-amarillo, amarillo-azul) dificultan la clasificación visual de los resultados. La obtención de resultados positivos en los métodos BRT MRL y Eclipse 100 estuvo relacionada con el elevado contenido de la grasa de la leche de cabra. También, el contenidfo en ácido butírico se asoció con las respuestas positivas en el método Eclipse 100. Mientras que, los resultados del Delvotest SP-NT MCS 
se vieron afectados por elevados valores de $\mathrm{pH}$ y altas concentraciones de ácido miristoleico y lactoferrrina. Estos porcentajes de resultados positivos se podrían minimizar llevando a cabo algunos pre-tratamientos de las muestras de leche antes de su análisis como la eliminación de grasa por centrifugación (3100 g a $4 \stackrel{\circ}{C}$ durante 10 minutos) y/o el calentamiento ( $80^{\circ} \mathrm{C}$ durante 10 minutos).

La mejora en la selectividad de los métodos microbiológicos para la detección de antibióticos en la leche de cabra es sin duda totalmente necesaria para evitar pérdidas económicas en las ganaderías, industrias lácteas así como en los laboratorios de control. Sin embargo, se debe señalar que la presencia de contaminantes en la leche de cabra se puede evitar en gran medida mediante la aplicación de buenas prácticas ganaderas destinadas a asegurar que la leche procede de animales sanos, y que ha sido obtenida bajo condiciones adecuadas de higiene, lo que garantiza la seguridad de la leche de cabra y sus productos derivados. 


\section{Resum}

La llet de cabra es destina fonamentalment a la fabricació de productes fermentats, en especial diferents tipus de formatge. Per tant, el control de residus d'antibiòtics en la llet és de gran importància, ja que la seua presència podria tindre repercussions negatives sobre les propietats tecnològiques de la llet, així com en la salut dels consumidors.

En els programes de control de la qualitat de la llet els mètodes microbiològics són àmpliament utilitzats en l'etapa de garbellament per a la detecció d'antibiòtics. No obstant això, pel fet que són mètodes inespecífics, altres substàncies diferents dels antibiòtics poden ser capaços d'inhibir el creixement del microorganisme del mètode $i$, per tant, ocasionar resultats falsos positius.

L'objectiu d'esta tesi ha sigut avaluar les interferències de la presència de diferents substàncies contaminants de la llet de cabra, sobre la resposta dels mètodes microbiològics més empleats per a la detecció antibiòtics a Espanya (BRT MRL, Delvotest SP-NT MCS i Eclipse 100). També, s'ha estudiat la influència de les característiques fisicoquímiques de la llet de cabra sobre els resultats falsos positius d'estos mètodes. La idoneïtat dels mètodes microbiològics per a la detecció d'antibiòtics en els calostres es va estudiar per mitjà de l'anàlisi de mostres de calostre $i$ de llet procedents de quaranta-tres cabres de raça Murciano-Granadina obtingudes cada 12 hores durant la primera setmana post-part. Els resultats van indicar que els mètodes microbiològics no són adequats per a l'anàlisi del calostre caprí, ja que es van trobar elevats percentatges de resultats dubtosos i positius (fins a un $37,2 \%$ a les 36 hores després del part).

Per a avaluar l'efecte de la mescla de calostre en la llet de cabra sobre la resposta dels mètodes de garbellament, es van analitzar mostres de llet de cabra sense antibiòtics amb diferents concentracions de calostre. Les majors interferències es van obtindre amb l'addició del calostre obtingut a les 12 i 24 hores després del part, sent el mètode BRT MRL el més afectat. També es van calcular les concentracions inhibitòries de calostre que produïxen el $5 \%$ de resultats positius en els mètodes microbiològics, estant compreses entre 5,1 i 34,6\%.

En un altre estudi, es va investigar la interferència que produïxen en els mètodes microbiològics els detergents i desinfectants empleats en les explotacions ramaderes per a la neteja del material de munyiment i tancs d'emmagatzemament de la llet. Per això, es van addicionar huit concentracions de diferents productes de neteja (5 àcids, 5 alcalins, 5 detergents d'ús domèstic i 1 desinfectant) a llet de cabra sense antibiòtics, i es van analitzar pels mètodes microbiològics de detecció d'antibiòtics. La presència de detergents àcids i de desinfectant, a base de hipoclorit sòdic, en la llet de cabra no va afectar la resposta dels 
mètodes. Al contrari, els detergents alcalins en concentracions $\geq 1 \mathrm{ml} / \mathrm{l}$ van donar lloc a resultats falsos positius en les proves microbianes (fins a un 16,7\%) i a concentracions de 4 $\mathrm{ml} / /$ el $100 \%$ de les respostes van ser positives. Respecte als productes de neteja d'ús domèstic, que se solen emprar en xicotetes granges i formatgeries, el detergent d'ús domèstic que conté lauril sulfat sòdic i etanol, va presentar un major efecte que la resta de productes assajats sobre els mètodes microbiològics, inclús a concentracions relativament baixes $(1 \mathrm{ml} / \mathrm{l})$. A més, la presència en la llet de cabra de detergents a baixes concentracions $(0,5 \mathrm{ml} / \mathrm{l})$ va modificar lleugerament la sensibilitat dels mètodes microbiològics per a l'amoxicilina, ampicilina, bencilpenicilina i cloxacilina, encara que no compromet la detecció d'estos antibiòtics als límits de seguretat (LMR).

Els residus d'antiparasitaris en la llet de cabra podrien ser una altra de les possibles causes de resultats falsos positius en les proves de detecció d'inhibidors. Per al seu estudi es va realitzar un experiment in vitro per a avaluar l'efecte de set antiparasitaris d'ús freqüent en el ramat caprí lleter, així com dos experiments en els quals diferents grups de cabres en lactació es van tractar amb albendazol i ivermectina. Cal assenyalar que la ivermectina està prohibida en el tractament d'animals productors de llet per a consum humà, encara que es va considerar interessant la seua inclusió en este estudi per a analitzar el potencial efecte dels seus residus en la llet.

En l'estudi in vitro, es van afegir huit concentracions diferents d'albendazol, closantel, diclazurilo, febendazol, levamisol, diazinón i ivermectina a llet crua de cabra sense antibiòtics. Els resultats van mostrar una gran variabilitat segons el mètode $i$ antiparasitari empleat. El mètode BRT MRL va ser el més sensible front els agents antiparasitaris, ja que va presentar concentracions inhibidores més baixes en comparació amb els altres mètodes per a produir un 5, 10 i 50\% de resultats positius. L'antihelmíntic closantel i l'ectoparasitari diazinón van ser els antiparasitaris que a concentracions relativament baixes van produir majors interferències en tots els mètodes de garbellament. Al contrari, es van necessitar concentracions més elevades de levamisol i ivermectina per a ocasionar resultats falsos positius en les proves microbianes.

Per a avaluar l'efecte dels residus d'albendazol sobre la resposta dels mètodes microbiològics, es van emprar díhuit cabres Murciano-Granadines en mitat de lactació tractades amb una única dosi oral d'albendazol (7,5 mg/kg de principi actiu per pes viu) comercialment registrat per a ovelles lleteres que presenta un període d'eliminació de 4 dies. Tant l'albendazol com els seus metabòlits no es van detectar per damunt del límit màxim de residus a partir del tercer dia del tractament. No obstant això, el mètode BRT MRL va 
mostrar una alta freqüència de resultats falsos positius durant els sis dies després de l'administració, que suggerix que altres factors relacionats amb l'aplicació de l'antiparasitari diferents de la concentració d'albendazol residual en la llet són capaços en alguns casos d'influir sobre la resposta dels mètodes de detecció d'inhibidors.

Quant a l'estudi de la ivermectina, vint-i-huit cabres Murciano-Granadines infestades per Sarcoptes scabiei var. caprae van ser tractades amb una dosi d'ivermectina per via subcutània (200 mg/kg de pes viu), que es va repetir als set dies després de la primera administració. Els residus d'este antiparasitari en llet de cabra es van detectar durant els quinze dies de l'experiment amb concentracions compreses entre 8,13 i 24,25 ng/ml. A més, tots els mètodes de garbellament van presentar resultats positius durant l'experiment, sent el BRT MRL el mètode que va presentar un major percentatge $(20 \%)$ en comparació amb el Delvotest SP-NT MCS (6,6\%) i Eclipse 100 (5,7\%). Estos resultats positius no es poden associar exclusivament amb la concentració de ivermectina en la llet de cabra, ja que les concentracions inhibitòries calculades en l'estudi in vitro previ van ser molt superiors a les quantificades en la llet de cabres tractades amb ivermectina. Per tant, les interferències trobades podrien estar relacionats amb canvis o alteracions causats per l'aplicació de l'antiparasitari o per la pròpia malaltia, que podrien afectar la resposta immune dels animals afavorint la presència de substàncies inhibidores en la llet.

També es va plantejar realitzar l'estudi de l'efecte de la composició de la llet de cabra sobre la selectivitat (resultats falsos positius) dels mètodes microbiològics. Per això, es van analitzar 200 mostres de llet de cabra individuals per mitjà dels mètodes microbiològics classificant els resultats de manera visual i instrumental. La selectivitat més elevada es va obtindre amb la interpretació instrumental respecte a la visual (94-99\% vs 90-96\%), ja que les mostres amb coloracions intermèdies (verd-groc, groc-blau) dificulten la classificació visual dels resultats. L'obtenció de resultats positius en els mètodes BRT MRL i Eclipse 100 va ser relacionada amb l'elevat contingut de greix de la llet de cabra. També, la concentració d'àcid butíric es va associar amb les respostes positives en el mètode Eclipse 100. Mentre que, els resultats del Delvotest SP-NT MCS es van veure afectats per elevats valors de $\mathrm{pH} i$ altes concentracions d'àcid miristoleic i lactoferrrina. Estos percentatges de resultats positius es podrien minimitzar duent a terme alguns pre-tractaments abans de la seua anàlisi com l'eliminació de greix per centrifugació ( $3100 \mathrm{~g}$ a $4{ }^{\circ} \mathrm{C}$ durant 10 minuts) i/o el calfament $(80 \stackrel{\circ}{ } \mathrm{C}$ durant 10 minuts) de les mostres de llet.

La millora en la selectivitat dels mètodes microbiològics per a la detecció d'antibiòtics en la llet de cabra és sens dubte totalment necessaria per a evitar pèrdues econòmiques en les 
ramaderies, indústries làcties així com en els laboratoris de control. No obstant això, s'ha d'assenyalar que la presència de contaminants en la llet de cabra es pot evitar en gran manera per mitjà de l'aplicació de bones pràctiques ramaderes destinades a assegurar que la llet procedisca d'animals sans, que ha sigut obtinguda baix condicions adequades d'higiene, el que garantix la seguretat de la llet de cabra i els seus productes derivats. 


\section{Contents}

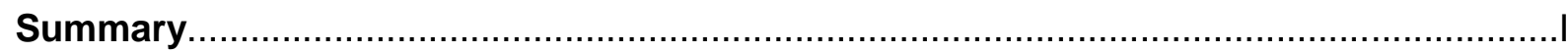

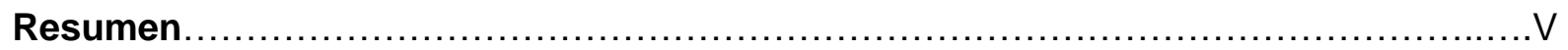

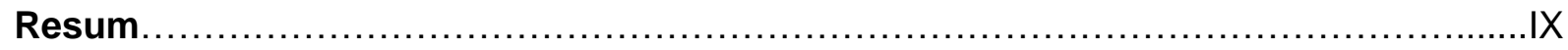

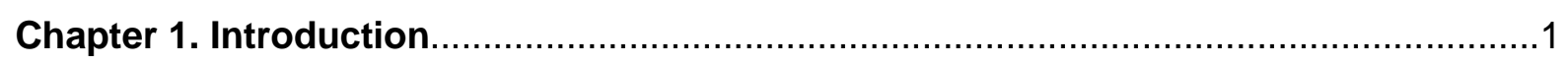

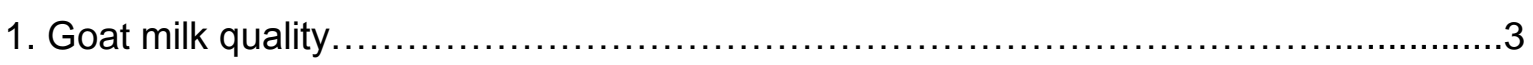

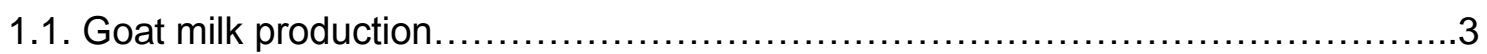

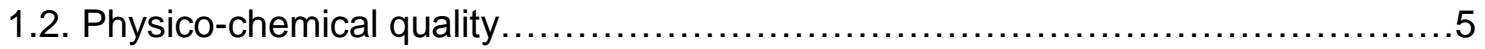

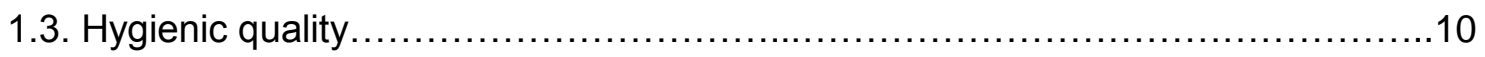

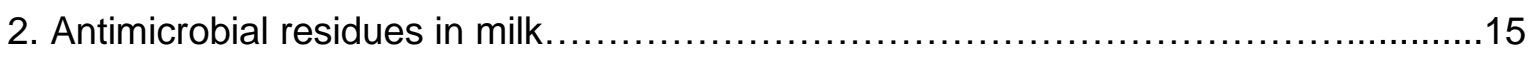

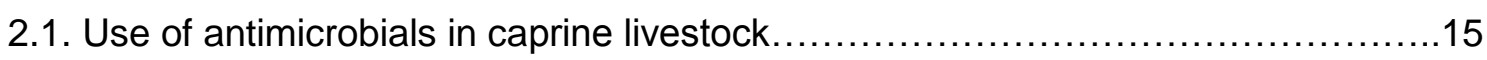

2.2. Consequences of the presence of antibiotic residues in milk.......................19

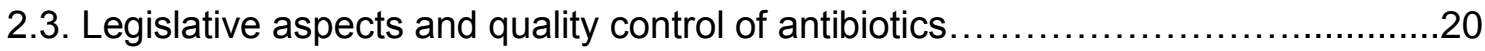

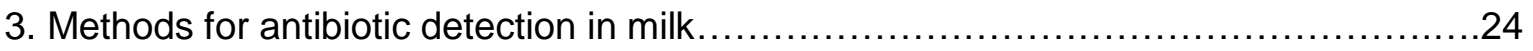

3.1. Detection system for monitoring of antibiotic......................................

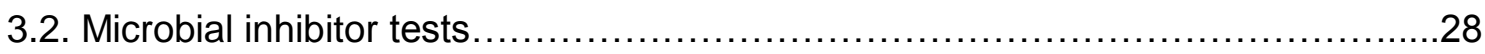

3.3. Interferences on the response of microbial inhibitor tests........................ 31

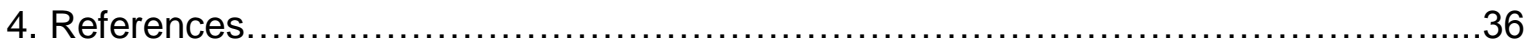

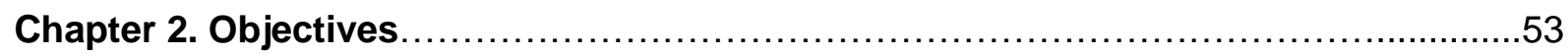

Chapter 3. Presence of colostrum on microbial screening methods for antibiotic

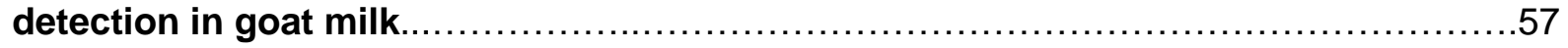

Chapter 4. The occurrence of positive results in microbial inhibitor tests due to the presence of detergents and disinfectants in goat milk ..........................................

4.1. Detection of antibiotics in goat milk: effect of detergents on the response of

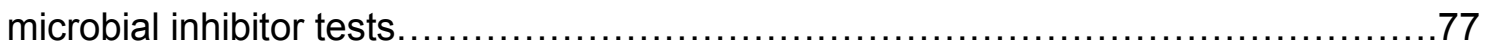

4.2. Interference of cleaning products for home use in goat milk on microbial inhibitor

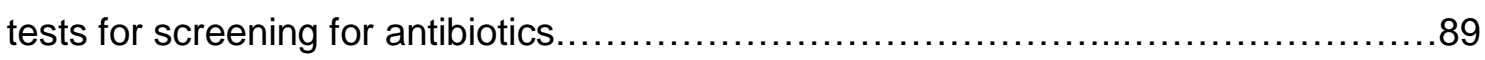

Chapter 5. Effect of antiparasitic drugs in goat milk on the incidence of positive results in microbial inhibitor tests. 
5.1. Antiparasitic drugs in goat milk: in vitro effect on the response of microbial tests for screening antibiotic residues.

5.2. Residues in goat milk after treatment with albendazole. Interferences on the microbial tests for screening for antibiotics

5.3. Interferences on microbial inhibitor tests related to ivermectin treatment in dairy goats

Chapter 6. Evaluation of the impact of goat milk quality on microbial screening tests

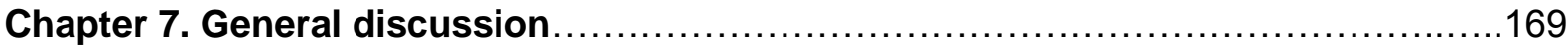

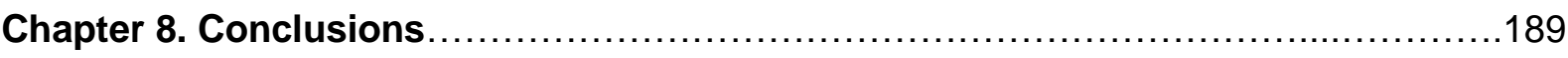

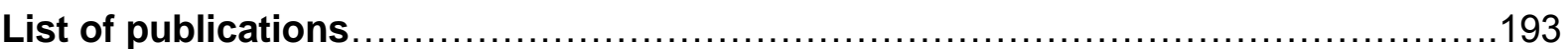




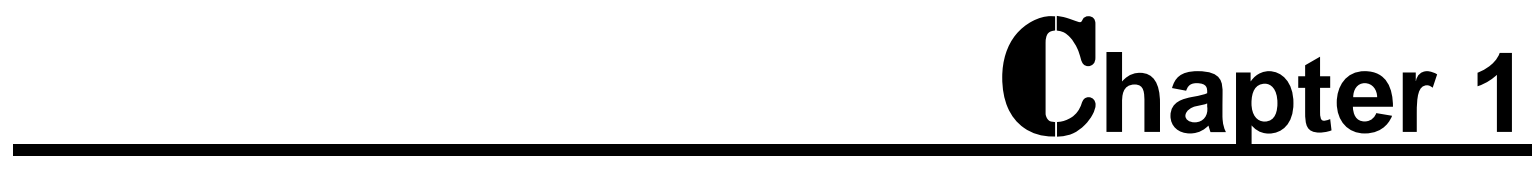

Introduction 



\section{GOAT MILK QUALITY}

\subsection{Goat milk production}

Goat farming worldwide is linked to the history of humans, who have managed and used goat products such as milk, meat and hair to suit human needs. These products are important indicators of the species' ability to adapt to multiple climates and systems, as goats can easily adapt to land that is not suitable for sheep and cattle farming (Boyazoglu et al., 2005; Silanikove et al., 2010).

The world production of goat milk in 2012 was 17.8 million tonnes (FAOSTAT, 2012). This production is distributed in a highly variable manner across the continents (Figure 1) and is focused in developing countries in Asia and Africa (> $80 \%$ ), where it is consumed in liquid form mostly by the farmer and his family. In Europe, however, 15\% (2.5 million tonnes of milk) is produced, and in other areas such as America and Oceania, production is very low.

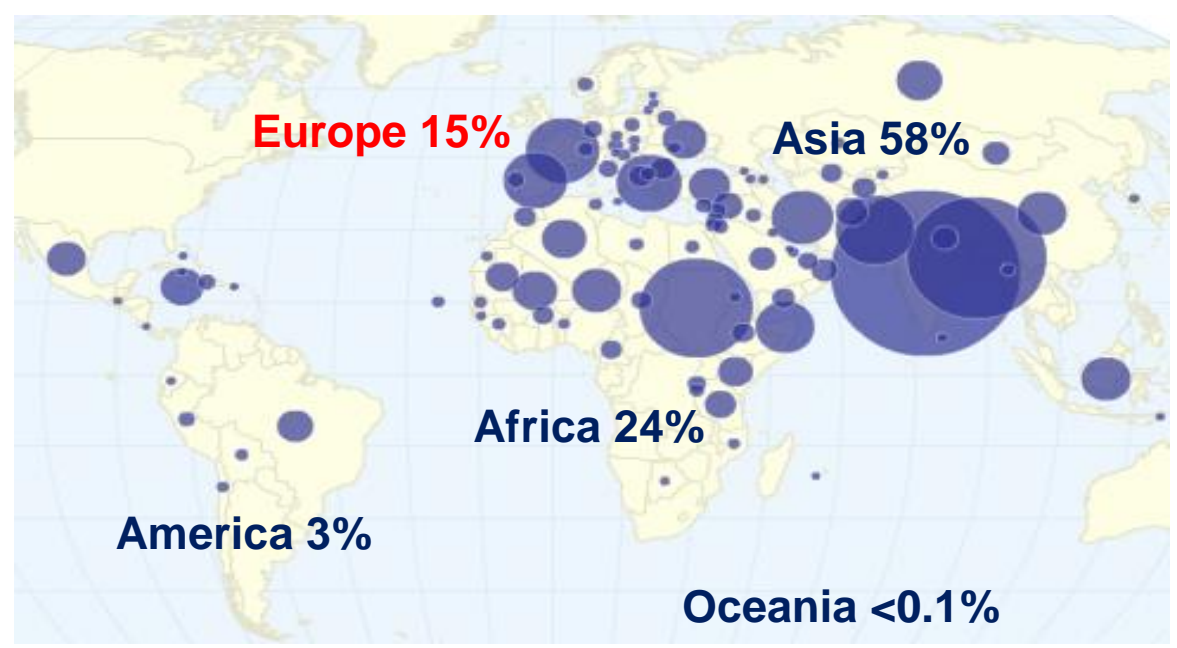

Figure 1. Goat milk production in the world (FAOSTAT, 2012)

Figure 2 shows the ten main producer countries of goat milk in Europe, highlighting France (24\%), Spain (17.5\%) and Greece (16\%). Also, other considerable producer countries are Russia, Ukraine and the Netherlands, with milk productions close to $10 \%(9.8$, 9.0 and $8.6 \%$, respectively). It is important to point out that the milk production of these six countries accounts for $84 \%$ of the total goat milk production in Europe (FAOSTAT, 2012).

In 2012, 466,702 tonnes of goat milk were produced in Spain. As shown in Figure 3, Andalusia is the region with the highest production (44\%) followed by the Canary Islands (19\%), Castile-La Mancha (13\%) and Murcia (8\%) regions (MAGRAMA, 2012). 


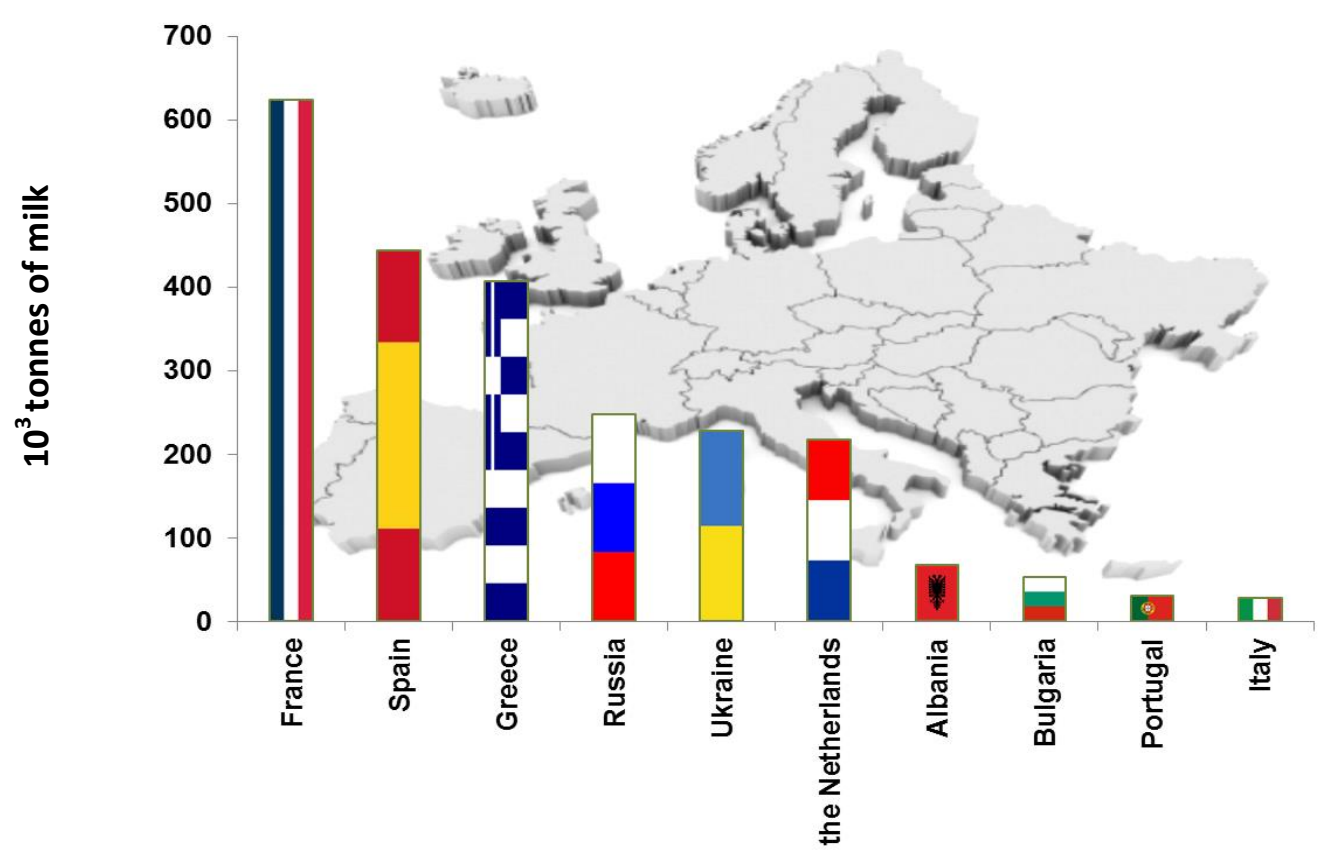

Figure 2. Top ten countries on goat milk production in Europe (FAOSTAT, 2012)

In Spain, the goat population (2.6 million goats) is mainly orientated toward milk production. The main breeds used for milk production are the Murciano-Granadina, Malagueña, Florida, Papaya, and Majorera (Castel et al., 2010). Moreover, there is a great diversity of goat farming systems in Spain coexisting the traditional and intensive farming (Mena et al., 2005). In recent years there has been a process of intensification and specialization with regards to milk production. Despite this intensification process, milk production remains strongly seasonal, with peak production in spring and minimum production at the end of the summer. However, in the case of intensive production systems, this fluctuation is reduced, since many farmers organize their animals in reproductive groups, so that milk production is more evenly distributed throughout the year (Sánchez et al., 2002).

Goat milk production in Spain is traditionally destined for the manufacture of dairy products (about 95\%), especially cheeses, of which five varieties (Ibores, Murcia, Murcia al vino, Palmero, and Majorero) have the protected designation of origin (PDO).

In recent years the quality of goat milk has become more important, since current systems for establishing the price of milk, especially in Europe, take into account aspects related to its composition (fat and protein content), and on occasion, bonuses or penalties are applied, depending on its hygienic quality (bacteriology, somatic cell count, inhibitors) and the presence of added water. In some European countries like France, in the case of goat milk, other parameters are included, such as immunoglobulin $\mathrm{G}$ content and the lipolysis 
index, and in countries such as Norway, a sensory evaluation of milk is also included as a quality parameter (Pirisi et al., 2007).

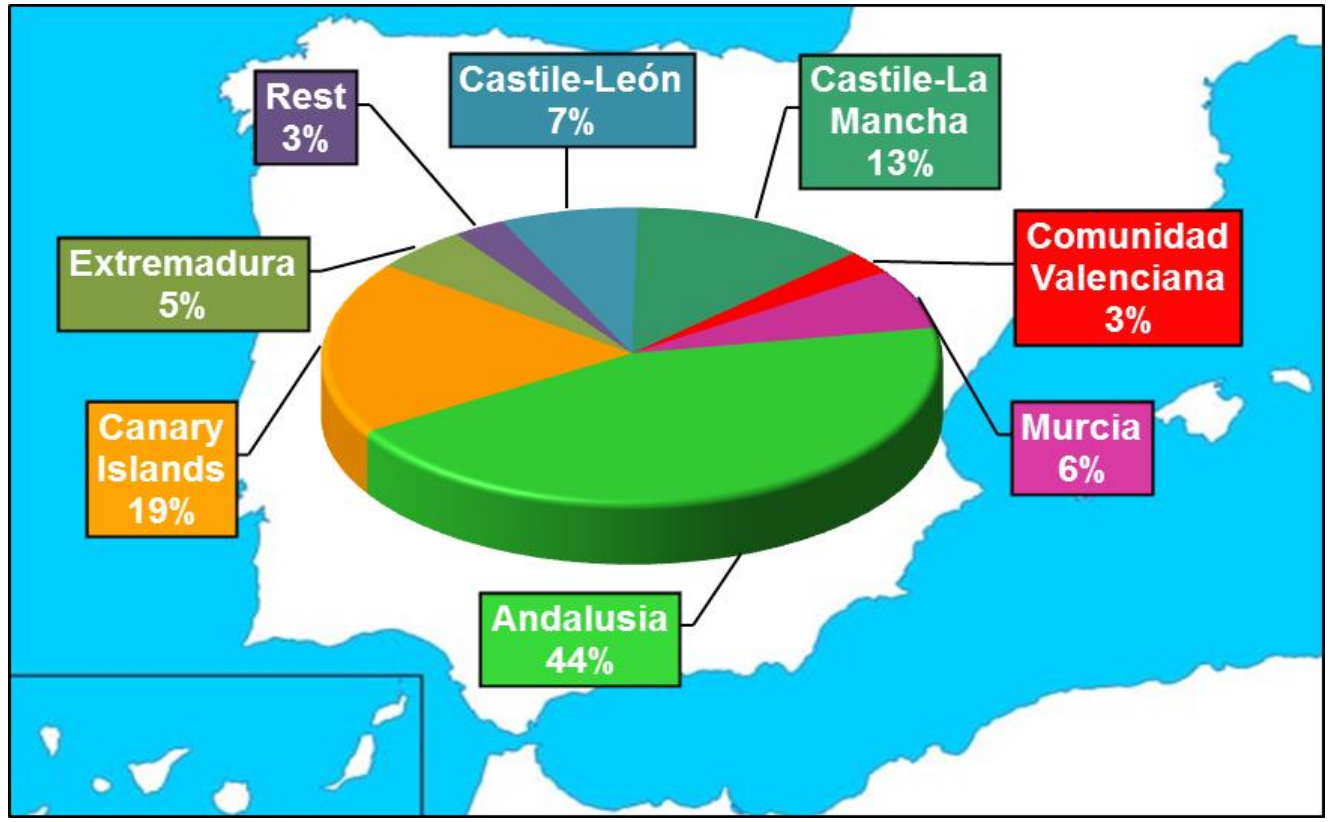

Figure 3. Distribution of milk produced by Autonomous Communities in Spain (MAGRAMA, 2012)

Therefore, the parameters that determine the quality of raw goat milk should be analyzed from two aspects, that is, the biochemical, i.e. physico-chemical characteristics and composition, and the hygienic.

\subsection{Physico-chemical quality}

Goat milk presents a better digestibility, alkalinity, buffering capacity and is from a medical viewpoint therapeutically as well as nutritionally more valuable than cow milk (Park, 1994).

Certain physical parameters are of special interest, as they allow the quality of raw milk to be assessed, such as its freezing point or density, which make it possible to identify fraud due to the addition of water in milk (Antutac et al., 2001), or its $\mathrm{pH}$ value and titrable acidity, which can be used as pointers to the hygienic quality of the milk. In Table 1 some of the most important physico-chemical parameters of goat milk are shown.

The quality of milk can also be assessed based on its chemical composition, which is of fundamental importance for its market value; it also affects its nutritive value, as well as its technological properties regarding processing (Lindmark-Mansson et al., 2003; Haenlein, 2004). 
Table 1. Physico-chemical parameters of goat milk according different authors

\begin{tabular}{|c|c|c|c|c|c|}
\hline $\begin{array}{c}\text { Specific gravity } \\
(\mathrm{g} / \mathrm{l})\end{array}$ & $\begin{array}{l}\text { Conductivity } \\
\left(\mathrm{mS} \mathrm{cm}^{-1}\right)\end{array}$ & $\begin{array}{l}\text { Freezing } \\
\text { point }(-\circ-\mathrm{C})\end{array}$ & $\begin{array}{c}\text { Acidity } \\
\text { (\% lactic acid) }\end{array}$ & $\mathrm{pH}$ & References \\
\hline $1,029-1,039$ & 4.3-13.9 & $0.540-0.573$ & $0.14-0.23$ & $6.50-6.80$ & $\begin{array}{l}\text { Park et al. } \\
\text { (2007) }\end{array}$ \\
\hline- & - & 0.560 & - & 6.86 & $\begin{array}{l}\text { Salvador et al. } \\
\quad(2006)\end{array}$ \\
\hline 1,030 & 5.1 & 0.554 & 0.15 & 6.70 & $\begin{array}{l}\text { Romero et al. } \\
\text { (2013) }\end{array}$ \\
\hline $1,028-1,030$ & - & - & 0.17 & - & $\begin{array}{l}\text { Almeida et al. } \\
\text { (2014) }\end{array}$ \\
\hline $1,029-1,032$ & 10 & $0.540-0.550$ & $0.15-0.17$ & $6.4-6.60$ & $\begin{array}{c}\text { Rawya and } \\
\text { Ahmed (2014) }\end{array}$ \\
\hline $1,028-1,032$ & $4.3-13.9$ & $0.540-0.573$ & $0.14-0.23$ & 6.4-6.86 & Range \\
\hline
\end{tabular}

The components of milk may be affected by different factors, such as the breed, stage of lactation, parity, season, feeding, management, reproduction, and sanitary characteristics (Chilliard et al., 2003; Morgan et al., 2003; Park et al., 2007; Goetsch et al., 2011).

Table 2 shows the average data of milk components for different goat breeds and countries. It is important to note that the milk of local breeds (i.e. Boer, Local breed from Greece, Nguni or Sardina) have a higher concentration of fat and protein and consequently dry matter, and are sometimes similar to sheep milk (Morand-Fher et al. 1991). However, the milk of more specialized dairy breeds (i.e. Alpine, Saanen, Nubian, etc) generally present a gross composition similar to cow milk (Park, 2005) with lower amounts of fat and protein, mainly due to the different production levels between breeds.

From the point of view of cheese making, the components of milk most related to their technological capacities are fat and protein, which are positively correlated to cheese yield (Verdier-Metz et al., 2001).

\section{$\underline{\text { Fat component }}$}

Fat is the most variable component of milk, both quantitatively and qualitatively, in terms of the cost, nutrition, physical and sensory characteristics that it gives to dairy products. Goat milk fat contains $97-99 \%$ free lipids ( 97\% are triglycerides) and $1-3 \%$ of bound lipids ( $47 \%$ neutral lipids and $\sim 33 \%$ polar lipids) (Cerbulis et al., 1982). 
Table 2. Gross composition of goat milk according to breed and countries

\begin{tabular}{|c|c|c|c|c|c|c|c|}
\hline Goat breed & Country & Dry matter & Protein & Lactose & Fat & Ash & References \\
\hline Alpine & Slovenia & 11.06 & 2.95 & 4.02 & 3.36 & - & Žan et al. (2006) \\
\hline Alpine & USA & $9.50-10.90$ & $2.40-2.80$ & - & $2.70-3.10$ & - & Soryal et al. (2005) \\
\hline Alpine & Brazil & 9.17 & 6.45 & 5.02 & 3.60 & 0.61 & Almeida et al. (2014) \\
\hline Boer & Africa & - & $4.97-5.03$ & $4.48-4.97$ & $6.13-6.39$ & & Mmbengwa et al. (2000) \\
\hline Damascus & Turkey & $11.30-12.90$ & $3.20-3.90$ & $2.3-4.9$ & $3.60-4.90$ & $0.68-0.89$ & Bhosale et al. (2009) \\
\hline Damascus & Cyprus & 13.20 & 3.75 & - & 4.33 & 0.83 & Raynal-Ljutovac et al. (2008) \\
\hline Local breed Greece & Greece & 14.80 & 3.77 & 4.76 & 5.63 & 0.73 & Raynal-Ljutovac et al. (2008) \\
\hline Grandina & Spain & 13.57 & 3.48 & 4.11 & 5.23 & 0.75 & Sanz Ceballos et al.(2009) \\
\hline Local beed India & India & $12.33-13.66$ & $3.21-4.09$ & $4.19-4.88$ & $3.54-4.54$ & $0.68-0.86$ & Bhosale et al.(2009) \\
\hline Nguni & Africa & - & $4.54-4.95$ & $4.27-4.51$ & $6.04-7.48$ & - & Mmbengwa et al. (2000) \\
\hline Nubian & USA & $13.2-14.6$ & $3.90-4.50$ & - & $4.40-4.50$ & - & Soryal et al. (2005) \\
\hline Nubian & United Kingdom & - & 3.60 & 4.51 & 4.94 & - & Raynal-Ljutovac et al. (2008) \\
\hline Crossbreed Canarias & Venezuela & 13.64 & 4.82 & - & 3.87 & 0.70 & Salvador et al. (2006) \\
\hline Murciano-Granadina & Spain & 12.82 & 3.21 & 4.37 & 4.87 & $0.75-0.95$ & López et al. (1999) \\
\hline Murciano-Granadina & Spain & 14.67 & 3.72 & 4.66 & 5.61 & - & Beltrán et al. (2014) \\
\hline Bristih Saanen & United Kingdom & 11.60 & 2.61 & 4.30 & 3.48 & 0.80 & Raynal-Ljutovac et al. (2008) \\
\hline Saanen & Slovenia & 12.26 & 3.40 & 4.36 & 3.77 & - & Žan et al. (2006) \\
\hline Saanen & Brazil & 11.61 & 3.55 & 4.85 & 3.15 & 0.68 & Almeida et al. (2014) \\
\hline Sardinian & Italy & - & 3.90 & - & 5.10 & 0.71 & Raynal-Ljutovac et al. (2008) \\
\hline Range & & $9.50-16.50$ & $2.40-6.45$ & $2.30-4.97$ & 2.7-7.48 & $0.61-0.95$ & \\
\hline
\end{tabular}


Lipids are present in milk in the form of globules ranging from 1 to $10 \mu \mathrm{m}$, goat milk fat is characterized by abundant small fat globules of a size less than $5 \mu \mathrm{m}(80 \%)$, while cow milk has a smaller quantity (60\%) of these small fat globules (Park, 2006).

Table 3 shows the fatty acids (FA) composition obtained by different authors. Fatty acid composition is an important determinant of milk nutritional quality, because certain FA have potential negative or positive effects on human health (Sébédio et al., 1999). Generally, goat milk fat contains $53-72 \%$ saturated FA, $26-42 \%$ mono-unsaturated FA and $2-6 \%$ polyunsaturated FA (Kouřimská et al., 2014).

Table 3. Concentration of the main fatty acids ( $\mathrm{g} / 100 \mathrm{~g}$ total fatty acids) in goat milk fat

\begin{tabular}{lcccc}
\hline & \multicolumn{3}{c}{ References } \\
\cline { 2 - 4 } Fatty acids & $\begin{array}{c}\text { Nudda et al. } \\
\mathbf{( 2 0 0 6 )}\end{array}$ & $\begin{array}{c}\text { Strzałkowska et } \\
\text { al. (2009) }\end{array}$ & $\begin{array}{c}\text { Sanz Ceballos } \\
\text { et al. (2009) }\end{array}$ & Range \\
\cline { 2 - 4 } & Sardinia & Polish White & $\begin{array}{c}\text { Murciano- } \\
\text { Granadina }\end{array}$ & \\
\cline { 2 - 4 } C4:0 (butyric) & - & $0.8-1.5$ & 1.3 & $0.8-1.5$ \\
C6:0 (caproic) & 1.6 & $4.2-5.9$ & 3.3 & $1.6-5.9$ \\
C8:0 (caprylic) & 2.0 & $5.0-6.1$ & 3.7 & $2.0-6.1$ \\
C10:0 (capric) & 8.2 & $13.5-15.7$ & 11.1 & $8.2-15.7$ \\
C12:0 (lauric) & 3.9 & $5.6-6.5$ & 4.45 & $3.9-6.5$ \\
C14:0 (myristic) & 10.7 & $11.1-12.3$ & 9.9 & $9.9-12.3$ \\
C14:1 (myristoleic) & 0.2 & $0.2-0.4$ & 0.2 & $0.2-0.4$ \\
C16:0 (palmitic) & 35.9 & $21.2-22.2$ & 25.6 & $21.2-35.9$ \\
C16:1 (palmitoleic) & 0.9 & $0.4-0.8$ & 1.0 & $0.9-1.0$ \\
C18:0 (stearic) & 6.9 & $5.8-9.1$ & 9.9 & $5.8-9.9$ \\
C18:1 (oleic) & 18.5 & $18.7-23.0$ & 23.8 & $18.5-23.8$ \\
C18:2 (linoleic) & 2.4 & $1.0-1.9$ & 2.7 & $1.0-2.7$ \\
C18:3 (a-linolenic) & 0.4 & $0.6-1.3$ & 0.5 & $0.4-1.3$ \\
\hline
\end{tabular}

The fatty acids, caproic, caprilyc, and capric acid (C6:0, C8:0, C10:0), contribute around $15-18 \%$ of the total fatty acid content in goat milk, compared to $5-10 \%$ in cow milk (Haenlein, 1993; Chillard et al., 2006; Raynal-Ljutovac et al., 2008; Sanz Ceballos et al., 2009). The concentrations of these fatty acids are associated with the characteristic "goaty" flavor or odour (Silanikove et al., 2010).

It should be noted that the most abundant FA in goat milk fat is palmitic acid (C16:0) reaching values of between 21.2 and $35.9 \%$ with regards the total FA (Table 3). The second most present fatty acid (18.5-23.8\%) is oleic (C18:1) just as different authors show in Table 3. These two FAs make up more than $50 \%$ of the fatty acid profile of goat milk. 
Milk unsaturated fatty acids may contain one or several trans double bonds. About 5 to $15 \%$ of the total oleic acid (C18:1) has a trans configuration in goat milk, with the transvaccenic acid the major isomer (35-40\%) of this fatty acid (Alonso et al., 1999). Among the poly-unsaturated FA it is important to highlight the conjugated linoleic acid (CLA), which is characterized by high biological activity and potentially beneficial health effects (Parodi, 2002; Zhang et al., 2006).

Dietary factor (forage-to-concentrate ratio, type of forages, etc) is the main environmental parameter regulating milk fat synthesis and fatty acid composition in ruminants (Bernard et al., 2009; Chillard et al., 2013; Nudda et al., 2013).

A parameter related to the fat composition in milk is the lipolysis that corresponds to the enzymatic hydrolysis of fat by lipases. The lipolysis can be produced spontaneously due to factors related to the animal, such as lactation state, feeding, health status, among others (Raynal-Ljutovac et al., 2005) and/or induced by mechanical treatments related to physical changes in the original fat globule membrane, occurring during agitation, foaming, homogenization, and freezing (Deeth, 2006).

Belliver and Gaborit (2000) and Enkaes et al. (2006) indicated a correlation between goat flavour and flavour defects (pungent, metallic, rancid, soap) in milk and cheeses with respect to the level of lipolysis. Because of this in France, the lipolysis level in the quality payment system for goat milk is included and milk samples with higher levels than 1.77 Meq/100 are penalised (Pirisi et al., 2007).

\section{$\underline{\text { Protein component }}$}

The total nitrogenous compounds in milk, two nitrogenous groups can be distinguished, the protein nitrogen (true protein) and the non-protein nitrogen. The nonprotein nitrogen varies in goat milk between 3\% and $7 \%$ of the total nitrogen (Remeuf and Lenoir, 1986; Park et al., 2007; Prosser et al., 2008). It consists of urea, free amino acids, nucleotides and nucleosides, polyamines, creatinine and other compounds containing nitrogen.

The proteins in milk and dairy products are very interesting from a nutritional point of view, since they have a high biological value due to their essential amino acid composition. The proteins are also important from a technological standpoint in the making of cheese and dairy products, and consequently, protein content is one of the main quality criteria used in the payment system of goat milk in many countries (Pirisi et al., 2007). 
The major protein fraction in milk (Table 4) is made up of caseins and whey proteins. Caseins ( $\alpha s_{1}$-casein, $\alpha s_{2}$-casein, $\beta$-casein, $\mathrm{k}$-casein) represent approximately $80 \%$ of the total protein. The whey protein, which constitutes approximately $20 \%$ of total protein, contains mainly albumins, such as $\beta$-lactoglobulin and $\alpha$-lactalbumin. Also, whey protein includes other minor proteins such as immunoglobulins, lactoferrin, ferritin, transferrin, proteose-peptone, glycomacropeptides, lactoperoxidase, lysozyme, prolactin and folatebinding protein and various growth factors (Selvaggi et al., 2014).

Table 4. Major protein fractions of goat milk according different authors

\begin{tabular}{lcccc}
\hline \multicolumn{1}{c}{ Protein fractions } & $\begin{array}{c}\text { Storry et al. } \\
\mathbf{( 1 9 8 3 )}\end{array}$ & $\begin{array}{c}\text { Greppi et al. } \\
\mathbf{( 2 0 0 8 )}\end{array}$ & $\begin{array}{c}\text { Claeys et al. } \\
\mathbf{( 2 0 1 4 )}\end{array}$ & $\begin{array}{c}\text { Selvaggi et al. } \\
\mathbf{( 2 0 1 4 )}\end{array}$ \\
\hline Caseins $(\mathrm{g} / \mathrm{L})$ & $21.4-31.8$ & $26-37$ & $23.3-46.3$ & 24 \\
\hline $\mathrm{\alpha}$-Casein & $3.4-11.2$ & - & - & - \\
$\alpha_{\mathrm{s} 1}$-Casein & - & $11-15$ & $0-13.0$ & 1.4 \\
$\alpha_{\mathrm{s} 2}$-Casein & - & $3-4$ & $2.3-11.6$ & 4.6 \\
$\beta$-Casein & $11.5-21.2$ & $9-11$ & $0-29.6$ & 13.1 \\
K-Casein & $4.2-5.9$ & $2-4$ & $2.8-13.4$ & 4.9 \\
Casein micel (nm) & - & - & 260 & - \\
\hline Whey proteins (g/L) & $3.7-7.0$ & $5.8-6.5$ & $3.7-7.0$ & 7.4 \\
\hline$\beta$-Lactoglobulin & $1.8-2.8$ & $3-4$ & $1.5-5.0$ & 3.9 \\
$\alpha-$ Lactalbumin & $0.1-1.1$ & $0.6-1.5$ & $0.7-2.3$ & 1.8 \\
\hline
\end{tabular}

The immunoglobulins are responsible for the passive immunity in newborns, and so are much higher in colostrum than in milk (Moreno-Indias et al., 2012). The immunoglobulin classes in goat milk are $\operatorname{lgG}(0.1-1.87 \mathrm{mg} / \mathrm{ml}), \operatorname{lgA}(0.03-0.11 \mathrm{mg} / \mathrm{ml})$ and $\operatorname{lgM}(0.01-0.22$ mg/ml) (Park et al., 2007; Romero et al., 2013; Sánchez-Macías et al., 2014).

The lactoferrin concentration in goat milk varies between $20-200 \mu \mathrm{g} / \mathrm{ml}$ (Chen et al., 2003; Park et al., 2007; Dračková et al., 2009). Additionally, its concentration level is usually higher during the colostrum period and at the end of lactation, when it reaches values of 387 $\mu \mathrm{g} / \mathrm{ml}$ (Hiss et al., 2008). The values for lactoperoxidase activity in goat milk are 0.63-3.47 $\mathrm{U} / \mathrm{ml}$ (Zapico et al., 1991), and the lysozyme quantity is $0.25 \mu \mathrm{g} / \mathrm{ml}$ (Chandal et al., 1968). These minor milk proteins show antimicrobial activity, and are precursors of various bioactive peptides (Atanasova and Ivanova, 2010), which are active against a wide range of pathogenic microorganisms (Listeria, Salmonella, Staphylococcus, etc). 


\subsection{Hygienic quality}

The nutritional quality of milk make it a basic foodstuff par excellence, but between being extracted from the udder and reaching the consumer, the milk is subjected to a large number of risks (i.e. growth of microorganisms, absorption of strange odours, presence of antibiotics, detergents, pesticides, etc), which may adversely affect the hygienic quality of the product.

To avoid these risks, the European Union published a comprehensive legislative framework on the hygiene of foodstuffs for human consumption (Regulation (EC) No 852/2004) and more specifically those of animal origin (Regulations (EC) No 853 and 854/2004). Among the parameters to be controlled in milk are the bacterial count, the somatic cell count and the presence of antibiotics.

The bacterial count refers to the total number of aerobic microorganisms which develop at a temperature of $30^{\circ} \mathrm{C}$, and is expressed as a number of colony-forming units $(\mathrm{cfu} / \mathrm{ml})$. The European Directive uses it as an indicative hygiene parameter during milk extraction and conservation in farms, establishing values of 1,500,000 and 500,000 cfu/ml for milk from species other than cow, for the manufacture of products based on heat treatment or non-heat treatment, respectively (Regulation (EC) No 853/2004).

Animal health, environment contamination, milking procedures and equipment sanitation can affect the microbial contamination of raw milk. Also, the length of time and storage temperature allows the bacterial multiplication of milk before it is processed. All these factors influence the total bacterial count and the types of bacteria present in raw milk (Reinemann et al., 2003; Zeng et al., 2007).

Microbiological quality control of milk is a very delicate task, given the great variety conditions to be found in small ruminant sector. The lack of milking machines and refrigeration tanks at farms and the transport of milk in unsuitable vehicles have a notable influence on the bacterial counts which can, reach high levels.

In Spain, Mena et al. (1999) indicated, from a hygienic management viewpoint, that although all farms observe general sanitary norms, most do not follow the general dairy herd recommendations for their milking routine. However, in a study carried out by DelgadoPertiñez et al. (2003) it was observed that most of the semi-extensive caprine farms studied, under the habitual management of each farmer, obtained a milk of acceptable bacteriological quality. These authors suggested that the establishment of appropriate conditions of hygienic 
management on the farms substantially improved the bacterial count and somatic cell count parameters.

On the other hand, the somatic cell count (SCC) is an indicator used to estimate the health of the mammary gland and the prevalence of mastitis processes, particularly in subclinical mastitis. The term somatic cell count refers to a concentration of blood cells such as leukocytes (macrophages, neutrophils, and lymphocytes), and epithelial cells in milk (Paape et al., 2001; Sordillo and Streicher, 2002).

It should be noted that after an intra-mammary infection (IMI), there is a significant increase in SCC in goat milk (Contreras et al., 1999; Raynal-Ljutovac et al., 2007). Bergonier et al. (2003) suggested that the SCC in bulk tank milk could be used to estimate the prevalence of IMI in dairy goats. However, according to studies by different authors, the increase of SCC in goat milk may be influenced by other non-infectious factors, such as the stage of lactation, parity, oestrus, method of milking, structure of udder and teats, management, stress, among others and they should be taken into consideration (Contreras et al., 1999; Zeng et al., 1999; Paape et al., 2001; McDougall and Voermans, 2002; Contreras et al., 2007; Raynal-Ljutovac et al., 2007).

The mastitis process is not only related to the decrease in milk production but also affects many of the components of it. Morgan and Gaspard (1999) observed that milk from infected goats showed a higher content of whey proteins, IgG, $\mathrm{Na}$, and $\mathrm{Cl}$, whilst parameters such as proteins, lactose, and casein were not influenced by mastitis. However, Ying et al. (2002) observed higher concentrations of protein and less lactose in the milk of diseased animals. In line with these authors, Leitner et al. (2004) also obtained a higher content in protein and a lower content in lactose in the milk of infected goats as well as high concentrations of whey protein and albumin.

Regulation (EC) No 853/2004 establishes for raw milk a maximum threshold of $400,000 \mathrm{cell} / \mathrm{ml}$, in the case of sheep and goat milk, it is not fixed, altrought in US the Pasteurized Milk Ordinance limit of in $1,5000,000$ cells $/ \mathrm{ml}$ for pasteurised goat milk.The influence of non-infectious factors, coupled with the particularity of the production systems in small ruminants and the lower socio-economic impact of these species has meant that the limits for this parameter have not yet been set in Europe.

Another parameter of great importance to assess hygienic quality is the possible presence in raw milk of antibiotics. Regulation (EC) No 853/2004 (Annex III, Section IX, Chaper III, 4 and 5) establishes "without prejudice to Directive (EC) No 96/23, food business operators must initiate procedures to ensure that raw milk is not placed on the market if: 
(a) it contains antibiotic residues in a quantity that, in respect of any one of the substances referred to in Annexes I and III to Regulation (EC) No 2377/90 (actually Table 1 in the Annex to Comission Regulation (EU) No 37/2010), exceeds the levels authorized under that Regulation.

(b) the combined total of residues of antibiotic substances exceeds any maximum permitted value".

When raw milk fails to comply with the Regulation (EC) No 853/2004 criteria, the food business operator must inform the competent authority and take measures to correct the situation.

All aspects related to control and detection of antibiotic residues in milk will be treated in more detail in sections 2 and 3 of the Introduction.

On the other hand, in agreement with Regulation (EC) No 852/2004 the general implementation of procedures based on the HACCP principles, together with the application of good hygiene practices are considered instruments to help food business operators attain a higher standard of food safety. Althogh the requirement of establishing procedures based on the HACCP principles should not initially apply to primary production, guides to good practice should encourage the use of appropriate hygiene practices at farm level.

Good Dairy Farming Practices (GDFP) must ensure that the milk and dairy products are safe and suitable for their intended use, and also that the dairy farm enterprise is viable into the future from the economic, social and environmental perspectives. To this end the "Guide to good dairy farming practice" (FAO and IDF, 2011) has been written for dairy farmers from any animal species, covering the key aspects of animal health, milk hygiene, nutrition, welfare, the environment, and socio-economic management (Figure 4). For each of these areas, the guide lists good dairy farming practices (Table 5) and suggests measures that can be implemented to achieve the desired outcome.

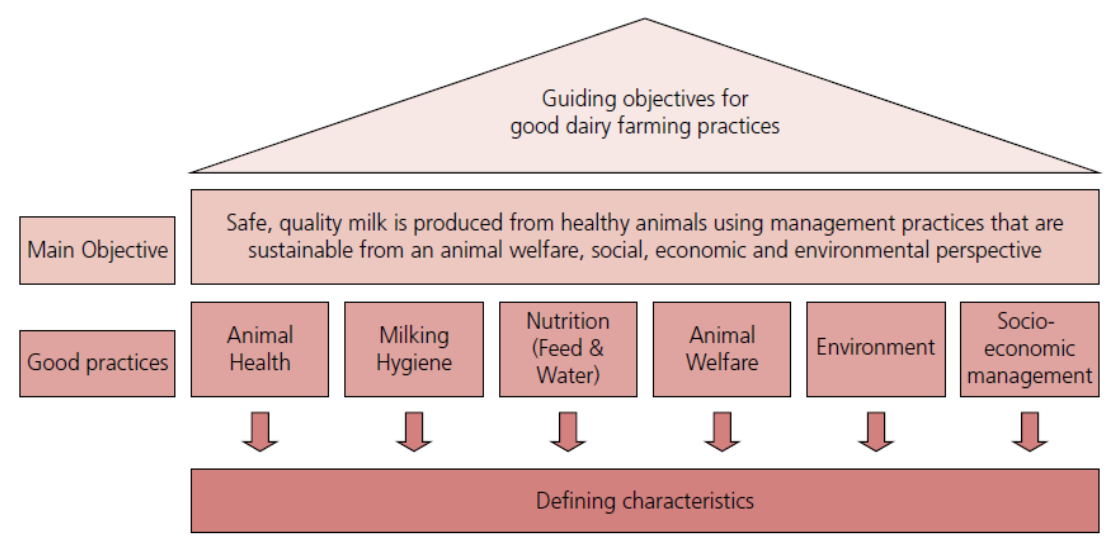

Figure 4. Guide to good dairy farming practice (FAO and IDF, 2011) 
Table 5. Guide lists good dairy farming practices (FAO and IDF, 2011)

\begin{tabular}{|c|c|c|}
\hline Area & Good dairy farming practice & Objectives \\
\hline \multirow{6}{*}{$\begin{array}{l}\text { 1. ANIMAL } \\
\text { HEALTH }\end{array}$} & 1.1 Establish the herd with resistance to disease & Enhance herd disease resistance / reduce stress \\
\hline & & $\begin{array}{l}\text { Maintain farm biosecurity } \\
\text { Keep animals healthy }\end{array}$ \\
\hline & 1.2 Prevent entry of disease onto the farm & $\begin{array}{l}\text { Comply with international/national/regional animal } \\
\text { movement and disease controls }\end{array}$ \\
\hline & & \\
\hline & $\begin{array}{l}\text { 1.3 Have an effective herd health management } \\
\text { programme in place }\end{array}$ & $\begin{array}{l}\text { Prevent spread of disease among animals } \\
\text { Ensure food safety } \\
\text { Ensure traceability }\end{array}$ \\
\hline & $\begin{array}{l}1.4 \text { Use all chemicals and veterinary medicines } \\
\text { as directed }\end{array}$ & Prevent occurrence of chemical residues in milk \\
\hline \multirow{4}{*}{$\begin{array}{l}\text { 2. MILKING } \\
\text { HYGIENE }\end{array}$} & $\begin{array}{l}2.1 \text { Ensure milking routines do not injure the } \\
\text { animals or introduce contaminants into milk }\end{array}$ & $\begin{array}{l}\text { Prepare animals for hygienic milking } \\
\text { Use suitable, well maintained and clean equipment for } \\
\text { milking and milk storage } \\
\text { Avoid contaminants in milk }\end{array}$ \\
\hline & & \\
\hline & $\begin{array}{l}2.2 \text { Ensure milking is carried out under hygienic } \\
\text { conditions }\end{array}$ & Harvest milk under hygienic conditions \\
\hline & 2.3 Ensure milk is handled properly after milking & $\begin{array}{l}\text { Minimise spoilage of milk after harvesting } \\
\text { Refrigerate and store milk under hygienic conditions }\end{array}$ \\
\hline \multirow{6}{*}{$\begin{array}{l}\text { 3. NUTRITION } \\
\text { (FEED \& } \\
\text { WATER) }\end{array}$} & $\begin{array}{l}3.1 \text { Secure feed and water supplies from } \\
\text { sustainable sources }\end{array}$ & $\begin{array}{l}\text { Provide the herd with adequate feed and water } \\
\text { Limit the potential impact of dairy feed production on the } \\
\text { environment }\end{array}$ \\
\hline & $\begin{array}{l}\text { 3.2. Ensure animal feed and water are of suitable } \\
\text { quantity and quality }\end{array}$ & $\begin{array}{l}\text { Keeping animals healthy with good quality feed } \\
\text { Preserve water supplies and animal feed materials from } \\
\text { chemical contamination }\end{array}$ \\
\hline & & \\
\hline & 3.3. Control storage conditions of feed & \\
\hline & & $\begin{array}{l}\text { Keeping animals healthy with good quality feed } \\
\text { Quality of the feeds fed to dairy animals is assured by the }\end{array}$ \\
\hline & $\begin{array}{l}\text { 3.4. Ensure the traceability of feedstuffs brought } \\
\text { on to the farm }\end{array}$ & $\begin{array}{l}\text { Prevent the use of feeds that are unsuitable for dairy } \\
\text { animals }\end{array}$ \\
\hline \multirow{8}{*}{$\begin{array}{l}\text { 4. ANIMAL } \\
\text { WELFARE }\end{array}$} & $\begin{array}{l}4.1 \text { Ensure animals are free from thirst, hunger } \\
\text { and malnutrition }\end{array}$ & Healthy, productive animals \\
\hline & 4.2 Ensure animals are free from discomfort & $\begin{array}{l}\text { Protection of animals against extreme climate conditions } \\
\text { Provide a safe environment } \\
\text { Justified and humane actions } \\
\text { Good sanitary conditions }\end{array}$ \\
\hline & $4.3 \mathrm{E}$ & Prevention of pain, injury and disease \\
\hline & disease & Prompt treatment of pain, injury and disease \\
\hline & & \\
\hline & 4.4 Ensure animals are free from fear & $\begin{array}{l}\text { Animals are less fearful of people, their handling facilities } \\
\text { and their environment. }\end{array}$ \\
\hline & & Safety of animals and people \\
\hline & $\begin{array}{l}\text { 4.5 Ensure animals can engage in relatively } \\
\text { normal patterns of animal behaviour }\end{array}$ & $\begin{array}{l}\text { Freedom of movement } \\
\text { Preserve gregarious behaviour and other behaviours, } \\
\text { such as preferred sleeping position }\end{array}$ \\
\hline \multirow{3}{*}{$\begin{array}{l}5 . \\
\text { ENVIRONMENT }\end{array}$} & $\begin{array}{l}5.1 \text { Implement an environmentally sustainable } \\
\text { farming system }\end{array}$ & $\begin{array}{l}\text { Dairy farming practices meet statutory and community } \\
\text { expectations }\end{array}$ \\
\hline & $\begin{array}{l}5.2 \text { Have an appropriate waste management } \\
\text { system. }\end{array}$ & $\begin{array}{l}\text { Limit the potential impact of dairy farming practices on the } \\
\text { environment } \\
\text { Dairy farming practices comply with relevant regulations }\end{array}$ \\
\hline & $\begin{array}{l}5.3 \text { Ensure dairy farming practices do not have } \\
\text { an adverse impact on the local environment }\end{array}$ & $\begin{array}{l}\text { Minimise the impact of milk production on the local } \\
\text { environment } \\
\text { Present a positive image of dairy farming }\end{array}$ \\
\hline \multirow{3}{*}{$\begin{array}{l}\text { 6. SOCIO- } \\
\text { ECONOMIC } \\
\text { MANAGEMENT }\end{array}$} & $\begin{array}{l}6.1 \text { Implement effective and responsible } \\
\text { management of human resources }\end{array}$ & $\begin{array}{l}\text { Ensure personal workloads are sustainable } \\
\text { Improve labour productivity } \\
\text { Protect dairy staff from exploitation } \\
\text { Limit risks to staff, livestock and infrastructure } \\
\text { Ensure farming enterprise is socially responsible }\end{array}$ \\
\hline & $\begin{array}{l}6.2 \text { Ensure farm tasks are carried out safely and } \\
\text { competently }\end{array}$ & Limit risks to staff, livestock and infrastructure \\
\hline & $\begin{array}{l}6.3 \text { Manage the enterprise to ensure its financial } \\
\text { viability }\end{array}$ & $\begin{array}{l}\text { Improve profitability } \\
\text { Limit risks to financial viability of enterprise }\end{array}$ \\
\hline
\end{tabular}


Without downplaying the other areas of activity in the GDFP, the areas most related to the presence of inhibitors in milk, the subject which this thesis focuses on, are "Animal Health," especially those aspects related to the use of chemicals and veterinary drugs and "milking hygiene," in everything related to the milking routine and the cleaning procedure of the surfaces that come into contact with milk.

The application of good practices in the use of all chemicals and veterinary medicines as directed is totally necessary to prevent the occurrence of drug residues in milk. The use of veterinary medicines contrary to the label recommendations (off-label use), a situation that occurs very frequently in goats, poses additional risks.

Consistency in the day-to-day implementation of milking procedures is an important part of good dairy farming practice for milking. Good practices ensure that milk is obtained and stored under hygienic conditions. The manufacturers' instructions should be followed when using cleaning and disinfectant products (always with authorised agents for this use) on milking equipment and tanks, including rinse processes followed of the application. These chemicals should be used in a way that ensures they do not have an adverse effect on milking equipment or on the milk quality.

Food business operators may use the GDFP on a voluntary basis as an aid to compliance with the food hygiene requirements. Member States are required to assess national guides to ensure that they satisfy the criteria laid down in the EU Regulations. In Spain, to provide guidance for the caprine sector, the Ministry of Agriculture, Fisheries and Food (2007) published the "Hygiene good practice guide" for goat farming, on meat and milk where the requirements and good practice are specified, grouped into the eight areas considered as the most important.

\section{ANTIMICROBIAL RESIDUES IN MILK}

\subsection{Use of antimicrobials in caprine livestock}

Veterinary medicinal products, especially antimicrobials, have gained greater importance in the animal health industry over the past 20 years, mainly due to the growing need to preserve the health and welfare of animals. The International Federation for Animal Health (IFAH-Europe, 2012) reports total sales of animal health products in the European market were 4.66 billion euros in 2012 , of which $41 \%$ corresponds to companion animals and the rest to animals for food production (59\%).

Figure 5 shows the European animal health market, which represents about $31 \%$ of the world market, with pharmaceutical products the most sold (62\%) followed by biologicals 
(26\%). The main substance groups in veterinary medicinal products in Europe (IFAH-Europe, $2012)$ are vaccines $(27.0 \%)$, antimicrobials (16.3\%), parasiticides (30.3\%), topical products $(6.7 \%)$, and other products (19.6\%).

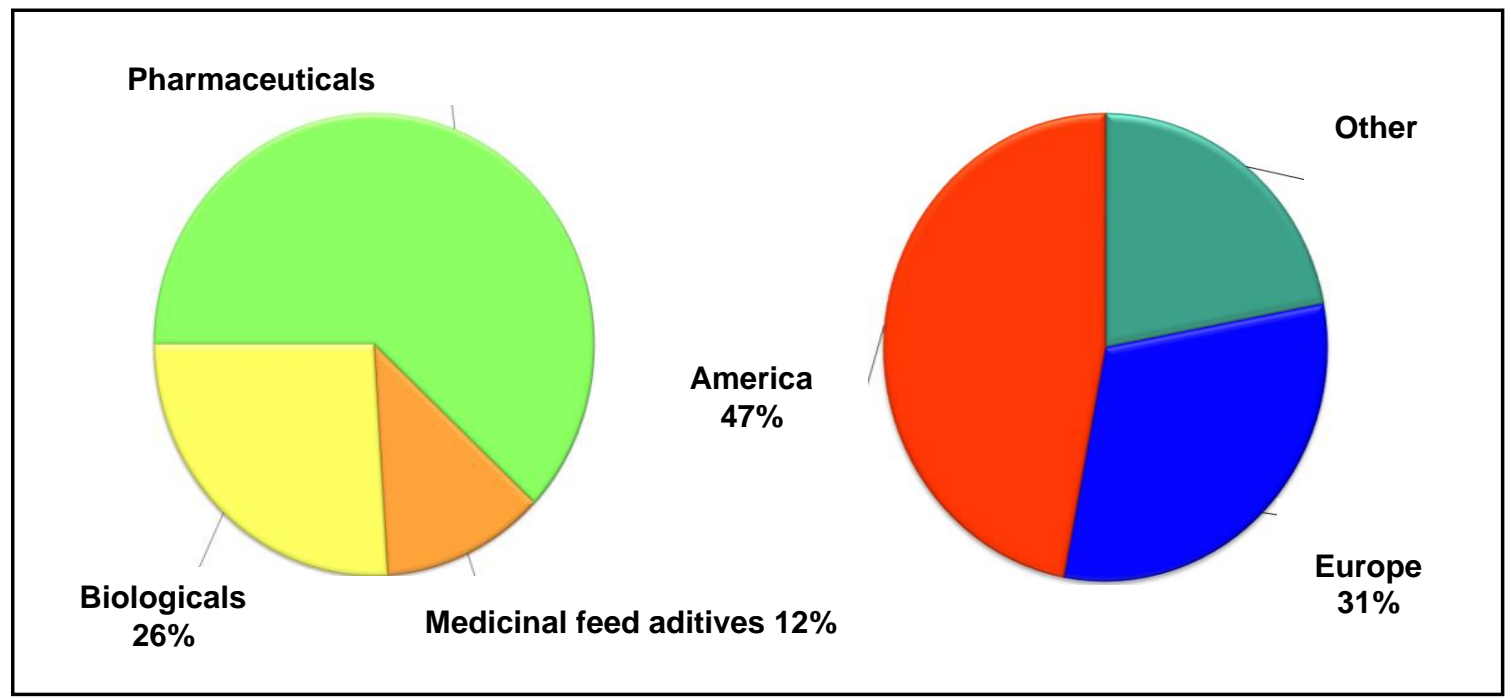

Figure 5. Animal health market in the world by region and product group (IFAH-Europe, 2012)

Concerning food-producing species in Spain, Figure 6 shows that the total sales of veterinary antimicrobial agents fluctuated during 2010 to 2012 (EMA, 2014). It can be seen that the sales of tetracyclines were higher than other antibiotics. A decreased in sales was observed for penicillins and fluoroquinolones, whilst an increase was seen for macrolides and sulfonamides.

On the other hand, is important to note that the caprine sector is one of the areas of primary production that has significantly evolved in recent years. The increase in production has in turn led to a further intensification of farms, causing adverse effects on animal health issues, such as a rising incidence of disease. This is due to the increased risk of the prevalence of diseases in goats (mastitis, tuberculosis, pneumonia, etc), which usually are treated with veterinary products such as antimicrobial drugs (Aungier and Austin, 1987).

Mastitis is the most common disease in dairy goats which causes high financial loss and veterinary costs (Menzies and Ramanoon, 2001; Contreras et al., 2007). The treatments of mastitis can be carried out during lactation to treat clinical mastitis, and in the dry-off period to reduce subclinical infections and prevent new infections for the next lactation (Gonzalo et al., 2004; McDougal and Annis, 2005). 


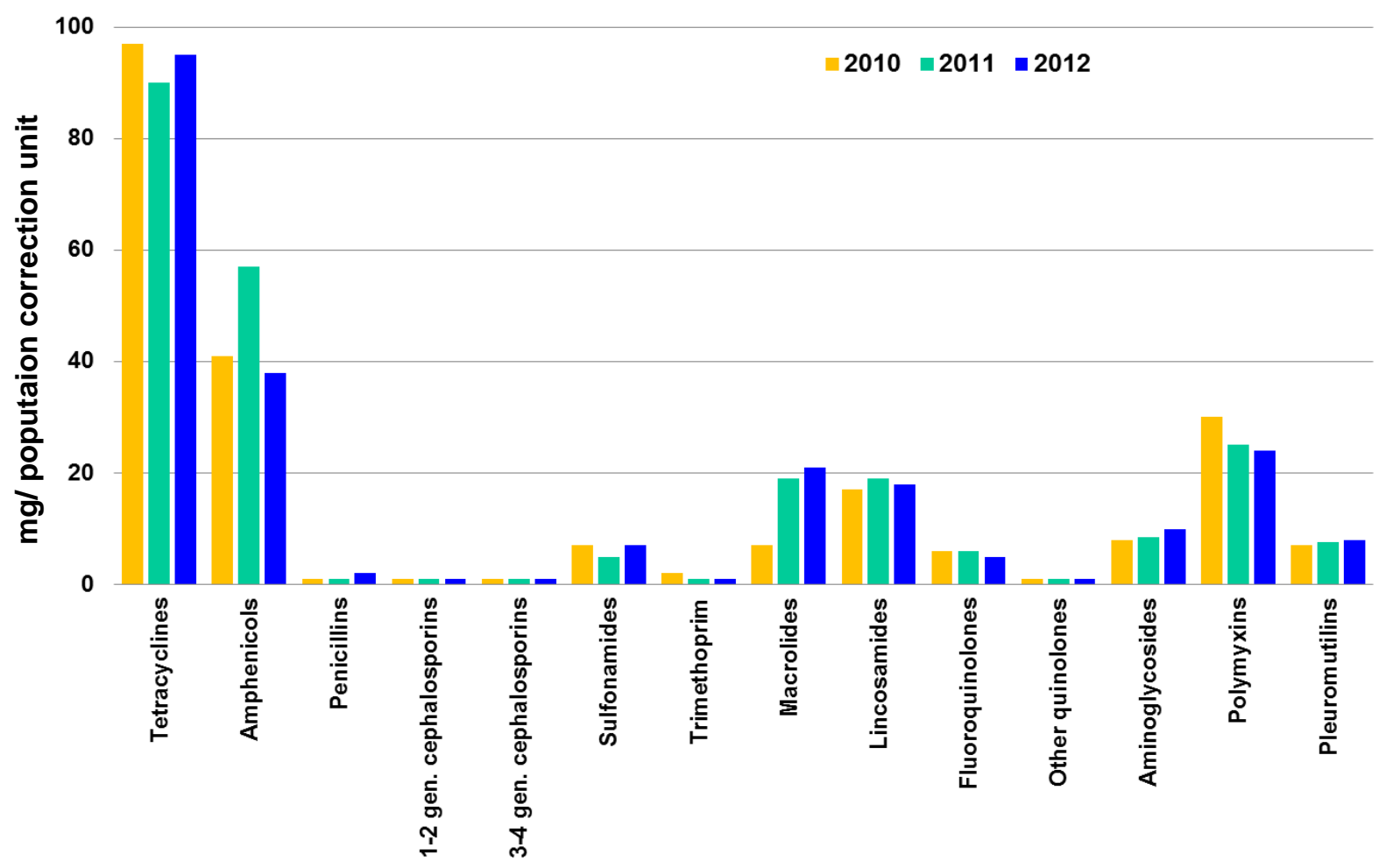

Figure 6. Sales by antimicrobial class for food-producing species in Spain for the period 2010 to 2012 (EMA, 2014)

In a study carried out by Berruga et al. (2008) for the Ministry of Agriculture, Food and the Environment (MAGRAMA) data are available about the drugs and treatments applied by veterinarians in dairy sheep and goats in Spain. According this report, a high percentage of veterinarians (76.9 and $73 \%$ ) usually treat clinical mastitis during the lactation and the dry-off period, respectively. The Figure 7 shows that the beta-lactams and macrolides are the main antimicrobial groups used to treat mastitis in the lactation period as well as in the dry-off therapy.

In addition to mammary infections, there are respiratory, reproductive and digestive diseases, among others, that require antimicrobial therapy in small ruminants. To treat pathologies other than mastitis, tetracyclines are the antimicrobial group of choice by veterinarians in dairy goats $(43.6 \%)$, with the beta-lactams the second most commonly applied antimicrobial group (26.3\%), according to Berruga et al. (2008).

A considerable aspect to be emphasized is the limited availability of antibiotic drugs registered for small ruminants, and some lack sufficient efficacy to treat specific disease conditions. Therefore, under cascade or off-label use is necessary for these species, especially in goats. In this regard, Berruga et al. (2008) indicate that $76.9 \%$ of the veterinarians in dairy goat farms use antibiotics under cascade, where $95 \%$ of the cases the veterinary drugs administered are registered for other species. 


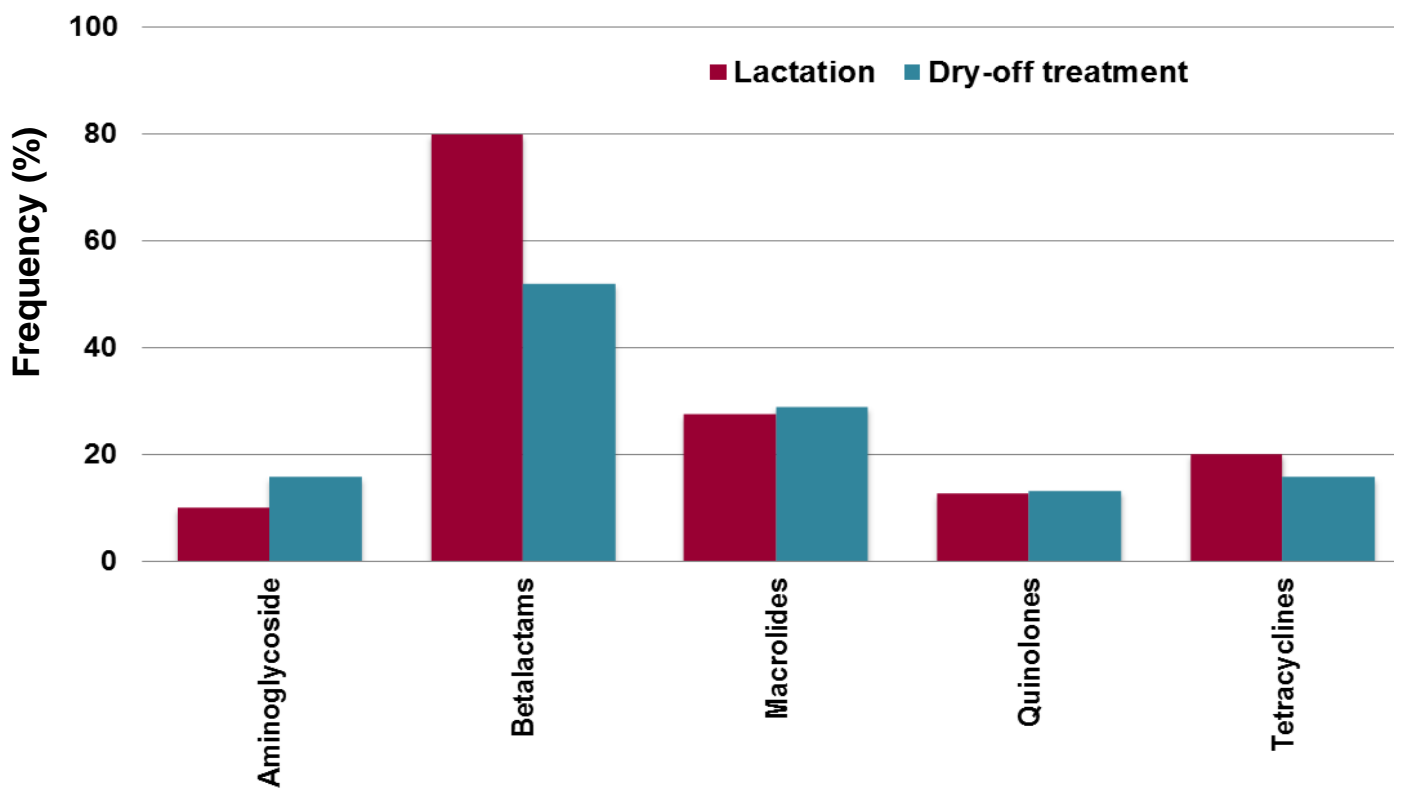

Figure 7. Frequency of use of antimicrobials in mastitis treatments (Berruga et al., 2008)

The under cascade use is regulated by European Directive 2004/28/EC and 2001/82/EC. A veterinary surgeon prescribing for, or administering a medicine to, foodproducing animals under the cascade is required to specify an appropriate withdrawal period to the animal produce. When setting the withdrawal period, a veterinary surgeon must take into account known information about the use of the product on the authorised species when prescribing to another species under the cascade. This legislation indicates that the withdrawal period for milk should be no less than seven days.

Some authors (Pengov et al., 2009; Ferrini et al., 2010) observed more time to ensure the absence of antimicrobials in milk. Debackere (1995) assumes that the withdrawal period is similar for goats and cows, although numerous authors (Bangen et al., 1992; Karzis et al., 2007) observed that the antibiotic residues persist for a longer period in goat milk than in cow milk. The risk of using antimicrobials not registered for caprine may cause residues in milk above the MRL and pose a hazard to the consumers' health since no correct depletion data in goats are available.

Recently, the International Dairy Federation published the "Guide to prudent use of antimicrobial agents in dairy production" (IDF, 2013), which provides a generic framework to support the responsible use of antimicrobial agents on dairy farms. The guidelines recognize that veterinarians (or appropriate authorised technical advisors) should help dairy farmers apply good farming practices by providing advice on the management of animal health, especially preventive measures that can preclude the need to use antimicrobial agents. 
The information on the occurrence of antibiotic residues in goat milk produced in Spain is limited. In the Murcia region, Marco et al. (2001) obtained 12.7\% positive results. However, Gonzalo et al. (2012), in the Castile and León region, showed the occurrence of non-compliant results decreased from $0.3 \%$ in 2005 to less than $0.01 \%$ in 2011 , showing a significant reduction due to the implementation of good farming practices and improvements in the dairy goat sector. Despite this reduction, the occurrence of antibiotic residues in milk is still an important issue, due to its implications for food safety.

\subsection{Consequences of the presence of antibiotic residues in milk}

The presence of antimicrobial residues in milk can produce numerous adverse conditions to human health, causing transient disturbances in the intestinal flora and allergic reactions (Tollefson et al., 2004; Demoly and Romano, 2005; Sanders et al., 2011). Allergies to beta-lactam drugs are very common, with an incidence of between 1 and $11 \%$ that can cause anaphylaxis, haemolytic anaemia and skin reactions (Guzman et al., 2004).

Moreover, the presence of antibiotics in foodstuffs may be responsible for the development of antibiotic resistances contributing to its propagation throughout the food chain (Phillips et al., 2004; Trobos et al., 2009; Oliver et al., 2011) as shown in Figure 8.

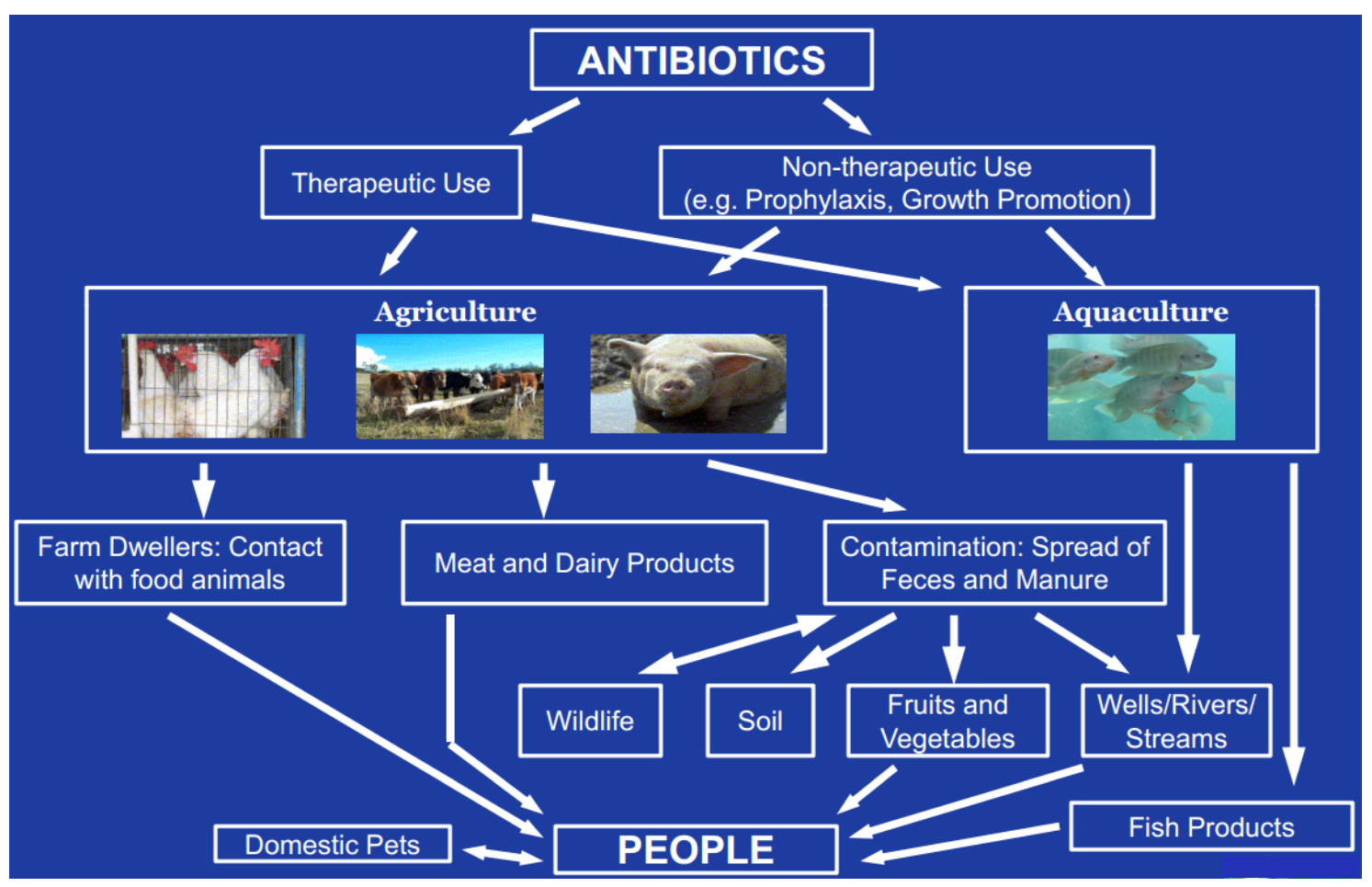

Figure 8. The flow of antibiotic resistance bacteria in animal food production (Wilson and Tam, 2010) 
The presence of antibiotics in milk can also cause technological problems, because the dairy starter cultures required for the elaboration of fermented products such as cheese and yoghurt may be inhibited by antibiotic residues (Packham et al., 2001; Berruga et al., 2007). In addition, goat milk is mainly used for this propose, with productions at farm level or in small dairies, in particular in Mediterranean and South-East European countries.

The technological damage produced by residues depends on the type of antibiotics, their concentration in milk and the type of product manufactured (Mäyrä-Mäkinen, 1995; Grunwald, 2003). It is important to note that most of the time the heat treatment commonly applied to milk in the dairy industry in order to reduce the microbial load and to eliminate pathogens and enzymes, has limited impact on the residues which can reach the consumer even after these treatments (Zorraquino et al., 2008, 2009, 2011; Roca et al., 2010).

Another aspect to consider is the possible financial impact of the presence of antibiotics in milk to the farmer, as it can lead to a ban by the competent authorities, if the raw milk is considered "unfit for human consumption" according to legislation. The possible restriction of the commercialization of the contaminated milk together with its storage and elimination costs, are the responsibility of the farmer and, therefore, the cause of major financial losses.

It should also be considered that significant amounts of antibiotics that are administered to animals are not metabolised and eliminated by milk, urine, and/or faeces (Kemper, 2008), contaminating the topsoil where they can accumulate or seep into the groundwater (Martínez-Carballo et al., 2007) with an effect on the microflora, the microfauna, and the groundwater quality, with serious environmental implications.

\subsection{Legislative aspects and quality control of antibiotics}

In the European Union, the control of the residues of veterinary products in foodstuffs of animal origin, such as milk, is regulated by Council Directive 96/23/EC. This directive lays down the measures requiring European member states to check those substances with an anabolic effect and any unauthorized substances and/or veterinary drugs and contaminants, within a national residue monitoring plan. The levels and frequencies for the sampling of milk and other animal products for the monitoring of these substances are stipulated in Commission Decision 97/747/EC. The principal objective of the legislation is to detect the illegal use of substances in animal production and the misuse of authorized medicinal products and to ensure the implementation of appropriate actions to minimize the presence of residues in food of animal origin. 
After publication of Regulation (EC) No 178/2002, which lays down the general principles and requirements of food law, having established the European Food Safety Authority and after defining procedures in matters of food safety, the EU began the publication of an extensive legislative framework in the field of food hygiene, which constitutes the general, basic and common principles for the production and marketing of all foodstuffs according to hygienic standards, and in particular, in the field of the production of raw milk from sheep and goats.

The responsibility of other operators in the food chain, on the production of safe food, was reaffirmed. Regulations (EC) No 852/2004 on the hygiene of foodstuffs, and (EC) No $853 / 2004$, lay down specific rules on the hygiene of foodstuffs of animal origin, in particular, general and specific standards of hygiene for the production of various food including the raw milk from sheep and goats. To ensure compliance with these hygienic rules, the European Union also published Regulation (EC) No 854/2004, which established specific rules for the organization of official controls on products of animal origin intended for human consumption.

Regarding the pharmacologically active substances used in veterinary treatments and for food safety, the EU has defined a series of legislative documents to ensure a high standard of protection for consumers. Council Regulation (EEC) No 2377/90 was the first such document related to the control of veterinary drugs, although it has now been repealed by Regulation (EC) No 470/2009. The new regulation describes the procedure for the establishment of Maximum Residue Limits (MRL) for pharmacologically active substances in veterinary medicinal products intended for food-producing animals, such as the maximum concentration of a residue of a pharmacologically active substance which may be permitted in food of animal origin.

The MRL is determined for each animal tissue, such as muscle, liver, kidney, fat or products as milk, eggs, honey, among others. To calculate the MRL value, the following items are taken into account: the metabolism and elimination of the active substance (veterinary product) in the target animal species, the type of residues generated and the amount which the general consumer can ingest throughout their lives without entailing risk to health, expressed as the acceptable daily intake (ADI).

Pharmacologically active substances and their classification regarding MRLs in foodstuffs of animal origin are set out in the Annex to Commission Regulation (EU) No 37/2010. Thus, all pharmacologically active substances and their metabolites are now organized in two separate tables: allowed substances and prohibited substances. 
On the other hand, the control of the traceability of foodstuffs and particularly those products of animal origin, was intensified due to the food crises in the 90s (such as mad cow disease) which generated social alarm about food safety, causing loss of confidence by consumers. Therefore, the EU established a set of mechanisms to ensure food safety, such as the development and implementation of the "hygiene rules", which cover all stages and sectors of production, to achieve the principle of food safety "from farm to the table". Regulation (EC) No 178/2002 establishes that the traceability of food and feed at every stage of production, processing and distribution, should be ensured.

In Spain, to comply with the Regulation (EC) No 178/2002 regarding the traceability of raw milk, the Ministry of Agriculture, Fisheries and Food (a.k.a. MAGRAMA) issued Real Decreto 217/2004. This Real Decreto regulates the identification and registration of agencies, establishments and entities involved in the dairy sector, and records the movements of milk, creating the "Letra $Q$ database" module (Leche, TRAzabilidad, Qualidad), a software application that registers all milk movements. Figure 9 shows the flow of milk movements during the production chain, from milking on the farm to delivery at collection centers and, and also shows the points where milk movement should be registered in the "Letra $Q$ database".

In order to guarantee compliance with the quality requirements set out in the Community Regulations on food hygiene (Regulations (EC) No 852 and 853/2004), ensuring that official controls for the presence of residues in animal products intended for human consumption are covered by regulations (EC) No 854/2004 and 882/2004, Real Decreto 1728/2007 establishes the basic control measures to be followed by operators in the dairy sector.

With regards to raw sheep and goat milk, Real Decreto 752/2011 establishes the mandatory minimum controls to be performed by agencies, the conditions required in quality control laboratories and the notifications to the "Letra $Q$ database". It also describes the aspects related to milk sampling in order to standardize the protocol in laboratories, as well as the use of preservatives such as azidiol, specifying the composition and dosage. Additionally, the obligation to transmit the results generated through the implementation of the checks carried out in accordance with the "Letra $Q$ database" established by Real Decreto $1728 / 2007$ was extended to the dairy sheep and goats sector. 
Concerning the established mandatory controls, monitoring the presence of antibiotics in raw milk from sheep and goats has to be carried out in farms before loading milk into the collection tanker, if there is suspicion or certainty of the presence of drug residues in milk. Screening for antibiotic residues in situ prior to the discharge of milk into the storage silos is mandatory in dairy centres. In both cases, Real Decreto 752/2011 requires the use of methods capable of detecting, at least beta-lactam antibiotics. At control laboratories, the screening tests for antibiotics that must be performed have to be able to detect, at minimum, the beta-lactam residues for all received samples (Annex IV, Real Decreto 752/2011). The actions to be taken in accordance with the result of the test for the monitoring for antibiotic residues in farms, dairy industries and laboratories, are outlined in Figure 10.

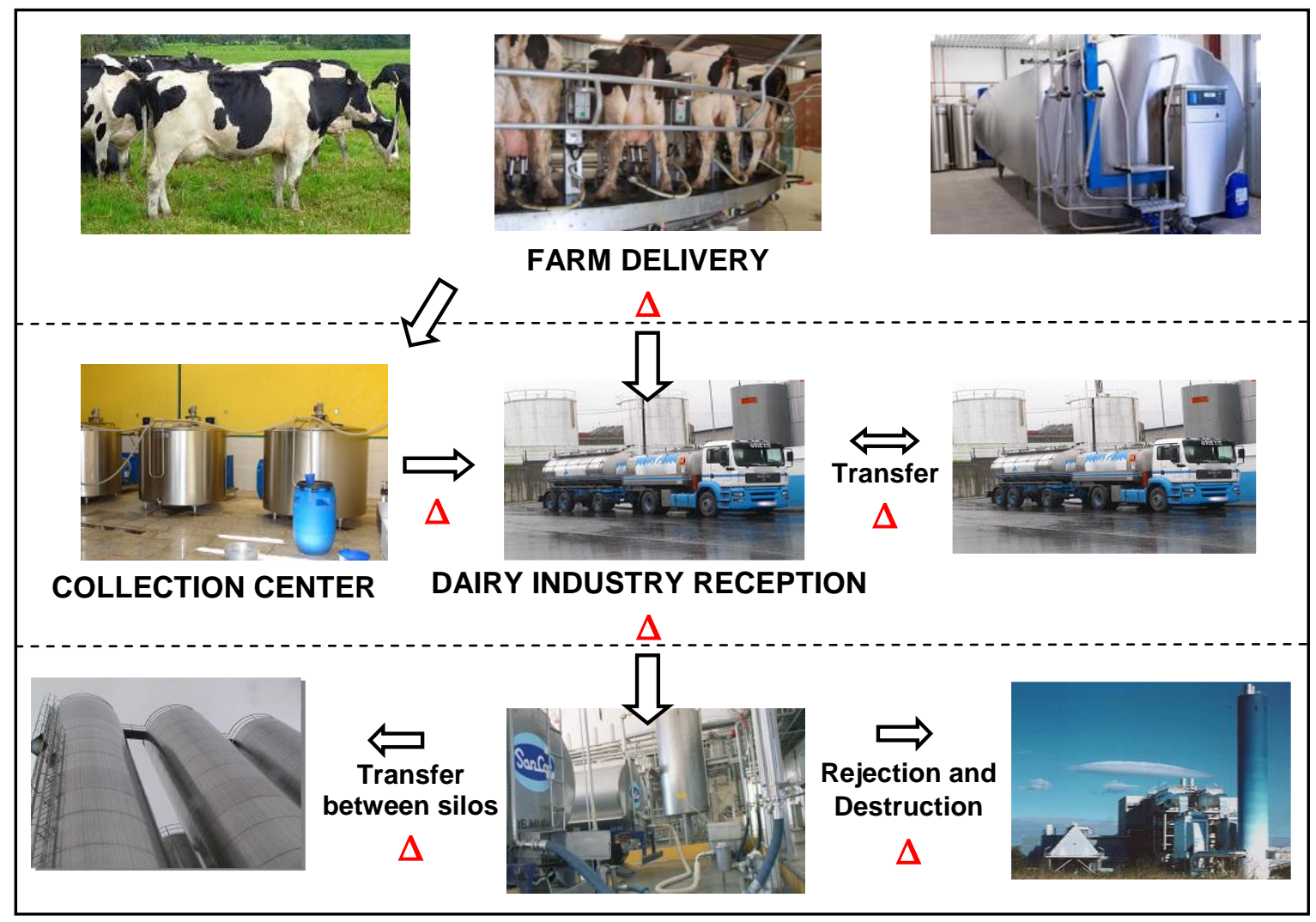

Figure 9. Diagram of the different stages in the system to ensure the traceability of raw milk $\Delta$ Control points where milk movement should be registered in the "Letra $Q$ database" (Real Decreto 217/2004)

The "Letra $Q$ database" will generate alarms to the competent authorities in the Autonomous Communities to communicate breaches in somatic cell count and bacteriology and any positive results in antibiotic tests on a daily basis. In the event of defaults, especially regarding antibiotic control, immobilization of the milk and its subsequent destruction will be carried out. 


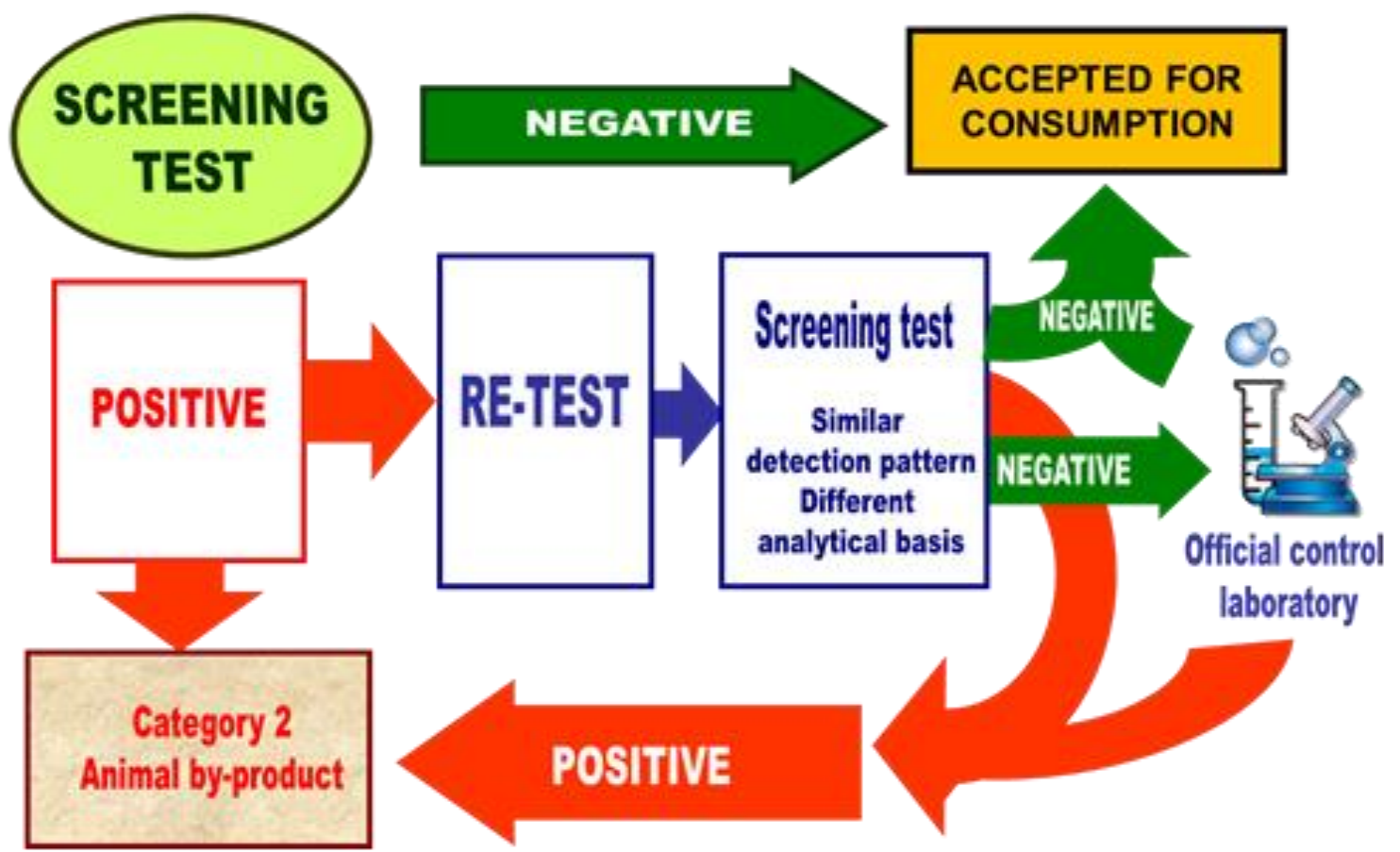

Figure 10. Plan of performance in the monitoring for the detection antibiotic residues in farms, dairy industries, and laboratories

\section{METHODS FOR ANTIBIOTIC DETECTION IN MILK}

\subsection{Detection system for monitoring of antibiotic residues}

The detection of antibiotic residues is a complex subject and to successfully address this task it is necessary to use an efficient analytical strategy that adequately combines the procedures and methods currently available in order to detect the greatest number of substances at the least possible economic cost.

To protect consumers and dairy products, an integrated control system with shared responsibilities for farmers, processors and food inspection is used. Recently the International Dairy Federation (IDF) published the guidance on the application of screening and confirmatory methods in integrated dairy chain management for the detection of antibiotic residues in milk (IDF, 2014).

The control program for antibiotic residues in milk is usually performed in two steps: a primary screening to detect potentially non-compliant samples and a second confirmation phase to identify the molecule present in the sample and to quantitate it (Figure 11).

The Commission Decision (EC) 657/2002 provides rules for the analytical methods (routine methods and reference methods) to be used in the testing of official samples and specifies common criteria for the interpretation of analytical results of the official control laboratories for such samples. The decision also classifies the analytical methods for the 
detection of inhibitory substances in milk as the qualitative methods and quantitative methods used in screening and the confirmatory steps, respectively.

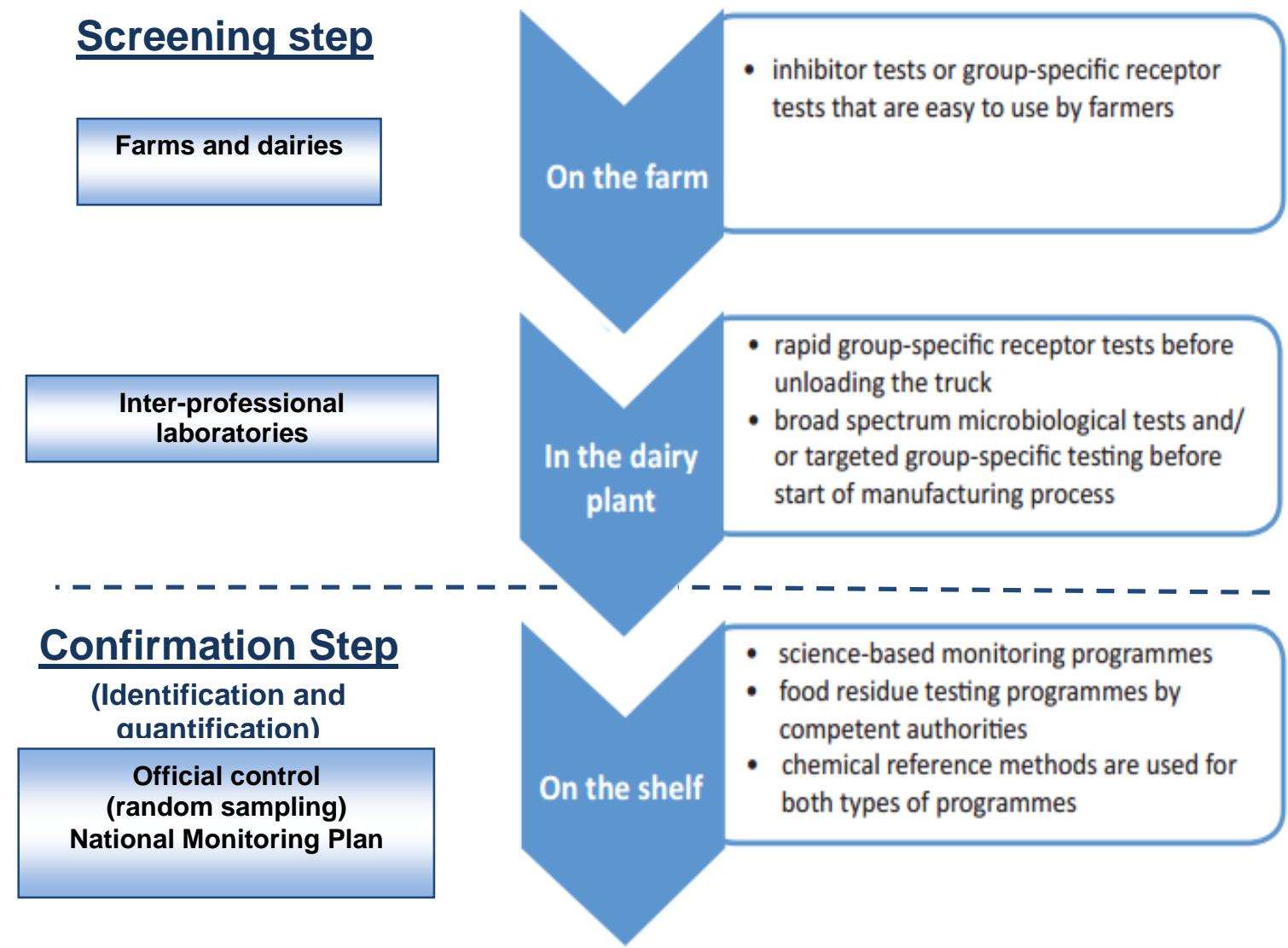

Figure 11. Guidance to detect and control antimicrobial residues in the dairy value chain (IDF, 2013)

Regarding residues, the Community Reference Laboratories have published the "Guidelines for the validation of screening methods for residues of veterinary medicines" (CRLs, 2010). This document supplements Commission Decision (EC) 657/2002 and covers two distinct phases in the validation process: the initial validation of screening methods in the originating laboratory and the shortened or 'abridged' validation of these methods in the receptor laboratory.

Qualitative methods are used for screening for antibiotic residues in milk, microbial inhibitor tests being the most frequently used in control laboratories to detect the presence/absence of any antibiotic residues in milk above the legally established safety limits. Additionally, screening methods include qualitative specific methodologies that allow a preliminary confirmation of residues. There are currently different types of enzymatic, 
immunological and receptor-binding assays commercially available, allowing detection of antibiotic residues in milk in a specific manner. Receptor-binding assays using lateral flow technology are the most usually employed for screening antibiotics in farms and dairies as they are easy to use and rapid response (generally, less than 10 minutes), having versions able to detect individual or simultaneously, different antibiotic families.

As for the confirmation phase, there are physico-chemical methods able to provide full or complementary information enabling the substance to be unequivocally identified and if necessary quantified at the level of interest. Numerous methodologies for the quantitative analysis of antimicrobial residues in milk have been developed. In general, physico-chemical methods for the confirmation of antimicrobials are based on the chromatographic separation of residues, particularly liquid chromatography (LC), followed by spectroscopic quantification, such as UV, fluorescence or mass spectrometry (MS).

Table 6 summarizes the various types of screening and confirmatory methods to detect antibiotics according to their principle, typical techniques involved, specificity, and precision as well as practical details on equipment, cost, time, and operator skills required. 
Table 6. Antibiotic testing methods: principles and results delivered (IDF, 2014)

\begin{tabular}{|c|c|c|c|c|c|c|}
\hline \multirow{3}{*}{$\begin{array}{l}\text { Result } \\
\text { Detection }\end{array}$} & \multicolumn{5}{|c|}{ Screening } & \multirow{3}{*}{$\begin{array}{c}\text { Confirmation } \\
\text { Confirms antibiotic } \\
\text { identity and accurate } \\
\text { concentration } \\
\text { Physico-chemical }\end{array}$} \\
\hline & \multicolumn{2}{|c|}{ Qualitative = positive/negative } & \multicolumn{2}{|c|}{$\begin{array}{c}\text { Semi-quantitative } \\
\text { with an estimated concentration }\end{array}$} & \multirow{2}{*}{$\begin{array}{l}\text { Quantitative with an } \\
\text { accurate concentration } \\
\text { Physico-chemical }\end{array}$} & \\
\hline & Biological & Biochemical & Biological & Biochemical & & \\
\hline Principle & $\begin{array}{l}\text { Detects cellular } \\
\text { metabolic } \\
\text { responses to } \\
\text { analytes }\end{array}$ & $\begin{array}{c}\text { Detects molecular } \\
\text { interactions between } \\
\text { antibiotics and ligands } \\
\text { (antibody or receptor } \\
\text { protein) }\end{array}$ & $\begin{array}{c}\text { Detects cellular } \\
\text { metabolic responses to } \\
\text { analytes }\end{array}$ & $\begin{array}{l}\text { Detects molecular } \\
\text { interactions between } \\
\text { antibiotics and } \\
\text { ligands (antibody or } \\
\text { receptor protein) }\end{array}$ & $\begin{array}{c}\text { Separation of } \\
\text { individual antibiotics } \\
\text { and physical detection }\end{array}$ & $\begin{array}{c}\text { Separation of } \\
\text { individual antibiotics } \\
\text { and physical detection }\end{array}$ \\
\hline Typical techniques & $\begin{array}{c}\text { Bacterial growth } \\
\text { inhibition }\end{array}$ & Immunoassay & $\begin{array}{c}\text { Bacterial growth } \\
\text { inhibition }\end{array}$ & Immunoassay & $\begin{array}{c}\text { Chromatography + } \\
\text { spectrometry }\end{array}$ & $\begin{array}{l}\text { Chromatography }+ \\
\text { mass spectrometry }\end{array}$ \\
\hline Methods & $\begin{array}{l}\text { Incubation with } \\
\text { bacteria in solution } \\
\text { plates or ampoules }\end{array}$ & $\begin{array}{l}\text { Lateral flow, ELISA, } \\
\text { biochip or } \\
\text { radioimmunoassay }\end{array}$ & $\begin{array}{l}\text { Plate test / inhibition } \\
\text { zone }\end{array}$ & Specific ELISA & $\begin{array}{l}\text { LC-UV, LC-FL, LC- } \\
\text { ECD, LC-MS, GC-FID }\end{array}$ & $\begin{array}{l}\text { LC-MS/MS } \\
\text { or LC-HRMS }\end{array}$ \\
\hline Interpretation & $\begin{array}{l}\text { Visual or } \\
\text { colorimetric ( } \mathrm{pH} \text { or } \\
\text { redox indicator) } \\
\text { Readers available }\end{array}$ & $\begin{array}{l}\text { Visual or colorimetric } \\
\text { readers available }\end{array}$ & $\begin{array}{c}\text { Visual } \\
\text { based on size of } \\
\text { inhibition zone } \\
\text { Quantitative estimation } \\
\text { possible only if known } \\
\text { substance }\end{array}$ & $\begin{array}{l}\text { Colorimetric } \\
\text { (labelling) with } \\
\text { calibration curve } \\
\text { Micro plate reader }\end{array}$ & $\begin{array}{l}\text { UV or FL-spectrometry } \\
\text { with calibration curve }\end{array}$ & $\begin{array}{l}\text { Mass spectrometry } \\
\text { with calibration curve }\end{array}$ \\
\hline $\begin{array}{l}\text { Analysis time } \\
\text { Precision }\end{array}$ & $\begin{array}{c}1-3,5 \mathrm{~h} \\
- \\
\end{array}$ & $\begin{array}{c}2-10 \min \text { to } 3 \mathrm{~h} \\
-\end{array}$ & $\begin{array}{c}\text { Several hours } \\
\text { Low }\end{array}$ & $\begin{array}{c}2-4 \mathrm{~h} \\
\text { Medium }\end{array}$ & $\begin{array}{l}1-2 \mathrm{~h} \\
\text { High }\end{array}$ & $\begin{array}{l}1-2 \mathrm{~h} \\
\text { High }\end{array}$ \\
\hline Specificity & $\begin{array}{c}\text { Not specific } \\
\text { broad spectrum, } \\
\text { several antibiotics } \\
\text { and families }\end{array}$ & $\begin{array}{c}\text { Specific } \\
\text { for one or several } \\
\text { antibiotics or families }\end{array}$ & $\begin{array}{c}\text { Not specific } \\
\text { Antibiotic families }\end{array}$ & $\begin{array}{l}\text { Specific } \\
\text { for one single } \\
\text { antibiotic }\end{array}$ & $\begin{array}{c}\text { Identification } \\
\text { determination of } \\
\text { individual antibiotics }\end{array}$ & $\begin{array}{c}\text { Spectrometric } \\
\text { identification and } \\
\text { determination of } \\
\text { individual antibiotics } \\
\end{array}$ \\
\hline $\begin{array}{l}\text { Antibiotics range } \\
\text { analysed } \\
\text { simultaneously }\end{array}$ & Large range & $\begin{array}{l}\text { Single antibiotic or } \\
\text { one or more families }\end{array}$ & Medium to large range & Single antibiotic & Small to medium range & Medium to large range \\
\hline Cost & Cheap & Cheap/medium & Cheap & Medium & Medium/expensive & Expensive \\
\hline Sample preparation & None or simple & None or simple & Medium & Simple to complex & Complex & Complex \\
\hline Equipment/complexity & Simple & Simple or medium & Simple & Medium & Medium & High \\
\hline User skills / training & Low & Low/Medium & Low & Medium & Medium/high & High \\
\hline $\begin{array}{l}\text { Typical application } \\
\text { level }\end{array}$ & From farm to dairy & From farm to dairy & $\begin{array}{c}\text { Collection Center to } \\
\text { dairy }\end{array}$ & Dairy silo & Dairy silo & Finished product \\
\hline
\end{tabular}




\subsection{Microbial inhibitor tests}

The microbial tests were the first methods developed in the 50 s to detect antibiotic residues (Mitchell et al., 1998), and are now one of the most used groups thanks to their simplicity, low cost, and wide range of detection.

Microbial screening or inhibitor tests are based primarily on the evidence of inhibition of growth of a specific organism, using different systems such as indicators of $\mathrm{pH}$, redox, or bioluminescence for the detection of this inhibition. These tests are considered broad spectrum and unspecific but the microorganisms used as test bacteria are of course not equally sensitive to all antibiotics. As a consequence, they detect some substances better than others. The microorganisms used in these methods include Streptococcus thermophilus (Mourot and Loussouron, 1981), Geobacillus stearothermophilus var. calidolactis (Carlsson and Björck, 1987), Bacillus cereus (Suhren et al., 1993), and Bacillus subtilis (Aureli et al., 1996), among others.

Currently, the commercial microbial tests most frequently applied in the screening of antibiotics in milk use Geobacillus steraothermophilus var. calidolactis as a test microorganism with a high sensitivity for many antimicrobial compounds, particularly the beta-lactam antibiotic group (Stead et al., 2008). Different versions of BRT (AiM, Germany), Delvotest (DSM Food Specialties, the Netherlands), and Eclipse (ZEULAB S.L., Spain) are some of the most tests commonly used in Spain.

The tests can be presented in a single ampoule or as 96-well plate in which a standardized number of bacterial spores are embedded in an agar medium containing selected nutrients and an indicator system ( $\mathrm{pH}$ or redox indicator). After the addition of a fixed volume of a milk sample to the ampoule or to the well, the test is incubated in a water bath, block heater, or reader-incubator for 2 or 3 hours. In the absence of an inhibitory substance present in the milk sample, the bacterial spores will grow and multiply, causing the colour of the agar medium to change from purple/blue to yellow. However if the milk sample contains inhibitory substances above the detection limit of the test, no growth will occur and the agar color will remain purple (Figure 12).

On the other hand, is important to note that the screening tests currently available for the detection of antibiotic residues in milk have been developed and optimized for use in cow milk. Validation of these tests for goat milk is very important for the selection of the most appropriate testing strategy to interpret correctly the results and to ensure good monitoring of antibiotics in dairy goat farms. 


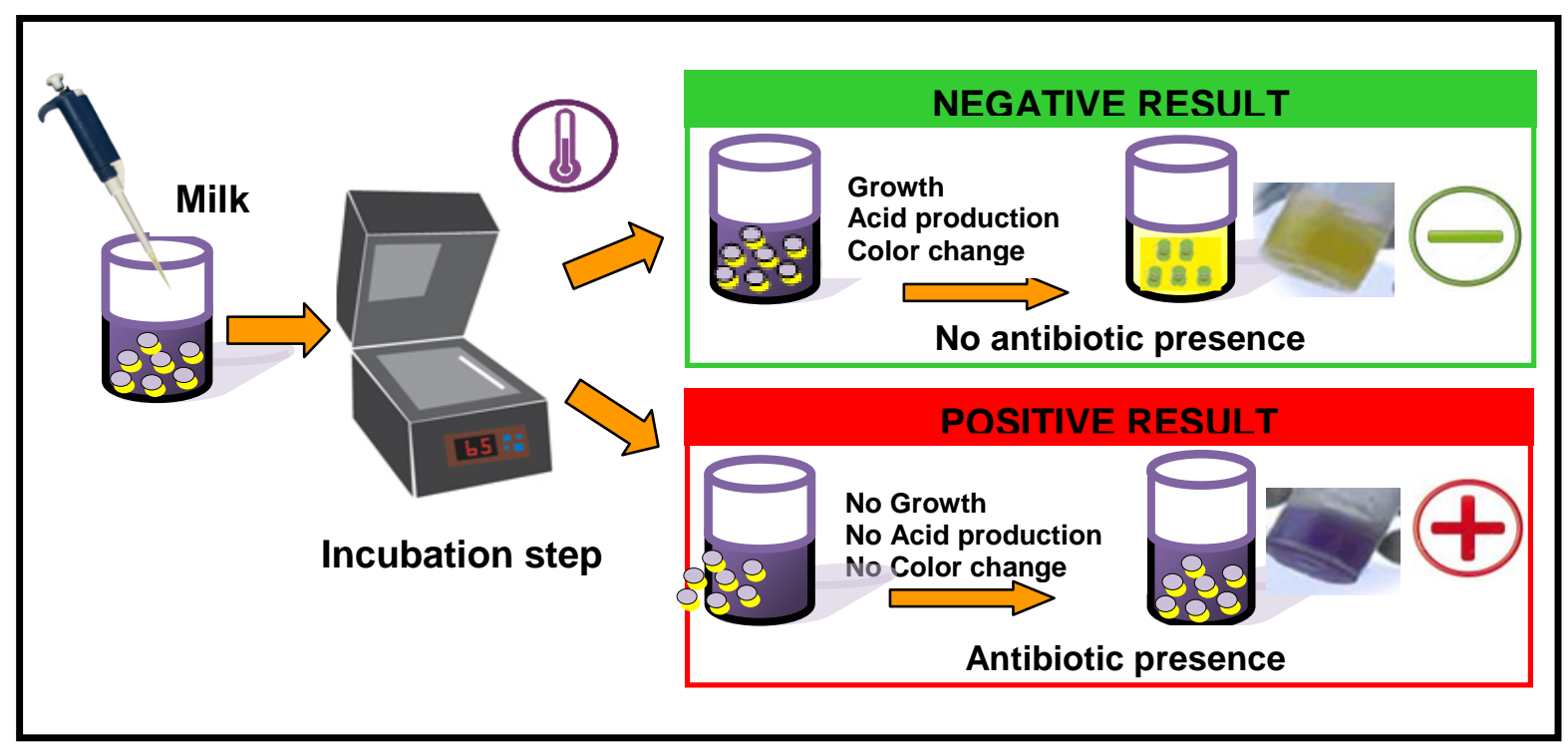

Figure 12. Principle of microbial inhibitor tests

As shown previously, different control purposes require various categories of methods. Commission Decision (EC) 657/2002 establishes the performance characteristics that should be verified for the validation of the analytical methods used for the detection of antibiotic residues in milk. Detection capability, specificity, and ruggedness are the performance characteristics that must be evaluated for qualitative screening methods.

Detection capability $(C C \beta)$ is defined in point 1.12 of the Annex to Commission Decision (EC) $657 / 2002$. CC $\beta$ is the smallest content of the analyte that may be detected, identified and/or quantified in a sample with an error probability of $\beta$. The $\beta$ error is the probability that the tested sample is truly non-compliant even though a compliant measurement has been obtained. For screening tests, the $\beta$ error (i.e. false compliant rate) should be $<5 \%$. Detection capability or detection limit $(D L)$ shows the sensitivity of the methods for different antimicrobial substances.

The detection capability of the microbial tests for a high number of antimicrobials in goat milk has been calculated by various authors (Sierra et al., 2009a,b; Beltrán et al., 2015), showing its high sensitivity to detect antibiotics belonging to the beta-lactam group. However, in spite of the improvements made to these tests over the last decade, they continue to be inefficient for other drugs, such as tetracyclines (except for Delvotest T, Charm Blue Yellow II), quinolones or aminoglycosides, employed for therapeutic and prophylactic treatments in dairy goats.

Specificity means the ability of a method to distinguish between the substance being measured and other substances. This parameter is the probability that the test will be 
negative for samples which do not contain residues of the target analyte. Therefore, specificity is associated with the presence of false positive results and is of great interest to evaluate the analytical capacity of a test. To determine it, a large number of milk samples from animals not treated with veterinary medicinal products should be analysed (ISO/IDF, 2002 and 2003).

Only a few authors have studied the specificity of microbial tests for goat milk in relation to the occurrence of false positive results. The studies showed a variable range from 0\% (no false positives) to 7\% (Zeng et al., 1996; Contreras et al., 1997; Beltrán et al., 2007, 2015) for different tests as Charm BsDA, Delvotest P, BRT MRL, Delvotest MCS, and Eclipse 100.

Ruggedness means the susceptibility of an analytical method to changes in experimental conditions which can be expressed as a list of the sample materials, analytes, storage conditions, environmental and/or sample preparation conditions under which the method can be applied as presented or with specified minor modifications.

Table 7 shows the advantages and limitations of microbial inhibitor tests compared to other screening methods. One of the main disadvantages of the microbial inhibitor tests is that they are unespecific. Due to of their lack of specificity, inhibitor tests may be affected by different substances that could inhibit microbial growth causing interferences leading to false positives results.

Table 7. Microbial inhibition tests: advantages and limitations (IDF, 2013)

\begin{tabular}{|l|}
\hline Advantages \\
\hline + Detection for a wide range of antimicrobials \\
+ Simple facilities for execution on-farm, dairy plant or in a laboratory \\
+ Required expertise is limited \\
+ Suitable for large scale testing in laboratories \\
+ Easy to automate \\
+ Relatively cheap \\
+ Group identification is possible ( $\beta$-lactamase and para-aminobenzoic acid) \\
\hline Limitations \\
\hline - Detectin capability for individual substances is widely different \\
- Not able to identify and quantity individual substance \\
- Subsequent confirmatory testing is needed \\
- Not fast; tests may take at least 2.5 hours \\
- Not specific for antimicrobial agents \\
- Susceptible to interfering substances in raw milk
\end{tabular}


The legislation does not specify an allowed percentage of false positive results for screening tests, but the user naturally has every reason to keep this percentage limited, since the occurrence of false positive outcomes in regulatory quality milk programs can have serious consequences, such as financial problems for farmers and dairy industries, as legal milk would have to be discarded.

\subsection{Interferences on the response of microbial inhibitor tests}

The interference on the response of microbial inhibitor tests can occur by different reasons such as if the test is sensitive to other structurally related compounds naturally present in the matrix or to contaminants. It is important to note that the studies on the causes or factors that provoke interference in the response of these tests focus primarily around cow milk, and there is little information on sheep milk, and almost none on goat milk.

Of the various reasons for interferences in microbial inhibitor test given by different authors (Table 8) are those related to the composition of the milk itself (fat, protein, natural inhibitors, etc), contaminants due to farming practices (detergents and disinfectants, antiparasitics, etc), as well as those caused by milk sampling and test procedure.

With regards the composition of milk, it has been seen that high concentrations of fat and protein milk can adversely affect the antimicrobial residue test performance (Andrew, 2000). The fat content of milk was positively related to an increase in false positive rates for several microbial tests (Reybroeck and Ooghe, 2012). However, these authors also indicated that low protein content may cause false positive results, which could possibly be explained by the fact that minimum protein content is essential for the normal growth of the test organism.

The false positive rate obtained by Althaus et al. (2003) in sheep milk for BRT and Delvotest were $3.75 \%$ and $2.40 \%$, respectively. The percentages of total solids for positive samples were significantly lower than negative samples (16.90 vs $18.42 \%$ for BRT, and 16.05 vs $18.45 \%$ for Delvotest). Recently, Beltrán et al. (2015) showed some higher levels ( $\geq$ $10 \%$ ) in microbial inhibitor tests for individual samples of sheep milk, and did not find any significant effect by the milk components.

In goat milk, Zeng et al. (1996) studied the performance of the Delvotest $P$, they obtained $7 \%$ false positive results compared to Charm BsDA. However, Contreras et al. (1997) did not find any positive results in Charm BsDA, Delvotest P and Delvotest SP showing a specificity of $100 \%$. Also, Beltrán et al. (2015) observed high specificity (> 95\%) 
for different microbial tests (BRT MRL, Delvotest MCS and Eclipse 100) for individual milk samples.

Table 8. Parameters that have an influence in the responses of microbial inhibitor tests

\begin{tabular}{|c|c|c|}
\hline Parameters & Specie & References \\
\hline $\begin{array}{l}\text { - Milk composition } \\
\text { Fat } \\
\text { Protein } \\
\text { Fatty acids }\end{array}$ & $\begin{array}{l}\text { Cow } \\
\text { Sheep } \\
\text { Goat }\end{array}$ & $\begin{array}{l}\text { Mäyrä-Mäkinen(1990); Carlsson and Björk (1992); } \\
\text { Andrew (2000); Reybroeck and Ooghe (2012) } \\
\text { Althaus et al. (2003); Beltrán et al. (2015) } \\
\text { Barbosa (1997); Beltrán et al. (2015) }\end{array}$ \\
\hline $\begin{array}{l}\text { Natural inhibitors } \\
\text { Lactoperoxidase } \\
\text { Lactoferrin } \\
\text { Lysozyme }\end{array}$ & $\begin{array}{l}\text { Cow } \\
\text { Sheep }\end{array}$ & $\begin{array}{l}\text { Carlsson and Björck (1987); Carlsson and Bjorck (1989) } \\
\text { Althaus et al. (2003) }\end{array}$ \\
\hline - Colostrum & Cow & Egan et al. (1984); Andrew (2001) \\
\hline - Mastitis (SCC) & $\begin{array}{l}\text { Cow } \\
\text { Goat }\end{array}$ & $\begin{array}{l}\text { Cullor et al. (1992); Kang and Kondo (2001) } \\
\text { Contreras et al. (1997) }\end{array}$ \\
\hline $\begin{array}{l}\text { - Detergents \& } \\
\text { sanitizers }\end{array}$ & Cow & $\begin{array}{l}\text { Merin et al. (1985); Schiffmann et al. (1992); } \\
\text { Zvirdauskiene and Salomskiene } \\
\text { Salomskiene et al. (2013) }\end{array}$ \\
\hline $\begin{array}{l}\text { - Milk sampling \& } \\
\text { test procedure } \\
\text { Preservative } \\
\text { Storage } \\
\text { Incubation time }\end{array}$ & $\begin{array}{l}\text { Cow } \\
\text { Sheep } \\
\text { Goat }\end{array}$ & $\begin{array}{l}\text { Oliver et al. (1984); Kang and Kondo (2001); Kang and } \\
\text { Kondo (2005); Reybroeck et al. (2014) } \\
\text { Molina et al. (2003); Zaadhof et al. (2004); } \\
\text { Montero et al. (2005) } \\
\text { Molina et al. (1999); Zaadhof et al. (2004) }\end{array}$ \\
\hline
\end{tabular}

The composition of goat milk on some occasions is similar to cow milk (Park, 2005) whilst on others it depends mainly on the breed and its productive level may show high levels of fat and protein, more similar to sheep milk (Beltrán et al., 2014). These differences in the composition of may have an influence in the different levels of false positive results shown previously in microbial tests.

Information regarding the effect of fatty acids on the inhibition of microbial tests is limited. Only Mäyrä-Mäkinen (1990) and Carlsson and Björk (1992) suggested a high concentration of fatty acids in cow milk could interfere with the test response. In a report about the occurrence of antibiotics, for sheep and goat milk, Barbosa (1997) indicated that a high level of butyric and capric acid was responsible for positive results when any antibiotic was present. However, Altahus et al. (2003) did not observe an effect of fatty acid composition in sheep milk for the response of the BRT and Delvotest methods. 
Other milk components that have been studied with regards the presence of positive results in microbial tests are the natural inhibitors (lactoperoxidase, lactoferrin and lysozyme), substances in milk that present antimicrobial activity. Carlsson and Björck (1987) showed that the lactoperoxidase system is not likely to interfere with the screening test, whilst the high concentration of lactoferrin or lysozyme in cow milk do not produce positive results in Delvotest $\mathrm{P}$ and also produce lower concentrations of both substances with a synergistic effect.

Carlsson et al. (1989) also studied lactoferrin and lysozyme in milk during acute mastitis and their inhibitory effect in Delvotest $\mathrm{P}$, and showed that the presence of positive results is related to an increased concentration of both lactoferrin and lysozyme.

Some of these effects caused by the composition of milk, especially the concentration of natural inhibitors, can be considerably minimised by the prior heating of the milk samples, as some authors have shown. In cow milk the thermal treatment at $82-85 \stackrel{\circ}{\circ}$ for 5 minutes reduced the positive results by $75 \%$ (Oliver et al., 1984) and by $85.7 \%$ (Kang and Kondo, 2005).

For goat milk, Molina et al. (1999) after the thermal treatment at $82{ }^{\circ} \mathrm{C}$ for 10 minutes showed a low reduction of doubtful (25\%) and positive (58\%) results for the BRT test. Also, with the same heat treatment carried out in ovine milk samples, Molina et al. (2003) observed a reduction of $100 \%$ of positive results for BRT and Delvotest in sheep milk, although the doubtful results were reduced by $50 \%$ for BRT and by $16.7 \%$ for Delvotetst.

Also, the presence of colostrum in milk can cause false positive results in microbiological assays for antibiotic residues. Egan et al. (1984) analysed bovine colostrum of the first milking by disc assays with different test microorganisms (Geobacillus stearothermophilus var. calidolactis, Bacillus subtilis and Streptocococcus thermophilus), obtaining for Geobacillus stearothermophilus var. calidolactis a specificity of $76.3 \%$. Furthermore, Andrew (2001) analysed bovine colostrum and transition milk using the Delvotest SP obtained a specificity of $88 \%$ and $92 \%$, respectively.

Concerning possible false positive results, due to mastitis and the high somatic cell count (SCC), Cullor et al. (1992) observed a significant effect of SCC on the frequency of positive results for different screening methods (BsDA, Charm Farm, CITE Prove, Delvotest P and Lactek) using individual milk samples from cows. Moreover, Kang and Kondo (2001) obtained a clear positive correlation between the SCC concentration in milk and the incidence of false positives results in the Delvotest SP. 
With regard ovine milk, samples with a high SCC have been related to the occurrence of false positive in BRT and Delvotest (Althaus et al., 2003). Besides, Beltrán et al. (2015) associated the high percentage of positive results (up to 10\%) in microbial screening tests with an increase in SCC, and the BRT MRL response was the least affected.

Contrary to the results obtained with cows and sheep, Contreras et al. (1997) did not observe positive results in goat milk samples with high SCC as well as low SCC in Charm BsDA, Delvotest P, and Delvotest SP showing $100 \%$ of negative results, which led the authors to suggest that they were appropriate for antibiotic screening in this specie. In the same way, Beltrán et al. (2015) did not observed in goat milk a relation between SCC and the false positives in the microbial tests.

The physical properties of mastitic milk change as a consequence of strong inflammation and the $\mathrm{pH}$ of milk increases from 6.6 to more than 7 . This reaction is mainly due to the transfer of bicarbonate ions from blood to milk (Korhonen and Kaartinen, 1995). This $\mathrm{pH}$ increase can cause false positive results in microbiological assays based on acid production as criterion for bacterial growth (Reybroeck, 2010).

Interferences in the results of microbial tests could be caused also by residues in milk as detergents, teat disinfectants, dairy sanitizers, parasiticides, herbicides, pesticides, and fungicides among others substances commonly used in farming practices (IDF, 2013).

Fabre et al. (1995), in France during official controls on 1,018 dairy cow farms, identified the cause of non-compliant results in $87 \%$ of the cases (516 milk samples). Among the different causes of false positives, they cited treatments related to clinical mastitis in lactation $(64 \%)$, dry cow therapy $(24 \%)$, pathologies other than mammary $(11 \%)$, teat hygiene (3\%), medicated feeds or antiparasitic treatments (1\%) and finally by poor cleaning of milking equipment (1\%).

Merin et al. (1985) studied the effect of detergents and disinfectants in cow milk on the response of the Delvotest method (Geobacilus stearothermophilus) and the TTC method (Streptococcus thermophilus), showing that high concentrations of products of the quarternary ammonium group interfere in the results of both methods. However, sodium hydroxide and sodium hypochlorite interfere in concentrations equivalent to recommended dose only in TTC.

The effect of acid and alkaline detergents on the response of the microbial tests has been evaluated in cow milk. Schiffmann et al. (1992) obtained non-compliant results at lower concentrations (0.01\%) in the BRT test. However, some authors, such as Zvirdauskiene and 
Salomskiene (2007) and Salomskiene et al. (2013) found false positive results in different microbial tests at very high concentrations of alkaline detergents, equal or superior to the dose recommended by the manufacturers, and for acid detergents no positive results were obtained for the different concentrations assayed.

On the other hand, Reybroeck, (2010) suggested that the presence of antiparasitic substances in milk could interfere in the results of microbial screening tests, although there are practically no studies and information on this subject.

Another cause that can affect the response of the methods is the storage conditions of milk samples. Borràs et al. (2013) indicated that positive results (milk samples spiked with antibiotics) in microbial inhibitor tests (BRT MRL, Delvotest MCS Accelerator and Eclipse 100 ) do not remain stable during storage time at $4 \stackrel{\circ}{\circ}$. They concluded that it would beneficial to carry out analyses within the first 48 hours after milk sampling.

Moreover, during storage in refrigerated conditions, the development of psychrotrophic flora (Pseudomonas spp) takes place. These bacteria have been related with non compliant results in microbial tests in cow milk, especially Pseudomonas tolaasii, which produces lipodepsipeptides (bactericins) with antimicrobial activity against Geobacillus stearothermophilus var. calidolactis, Staphylococcus aureus, Bacillus cereus, and Bacillus subtilis and interfering in milk tests (Reybroeck et al., 2014).

The use of preservatives in the milk samples can also increase the number of positive results and therefore modify the specificity of the methods. Molina et al. (2003) studied the effect of the use of two preservatives, potassium dichromate and azidiol, on the response of the BRT AiM and Delvotest MCS methods in sheep milk. These authors showed that potassium dichromate inhibited totally the growth of Geobacillus stearothermophilus, while with azidiol a selectivity of $90.2 \%$ was obtained, an amount lower than that obtained in samples without conservatives (96.3\%). Montero et al. (2005), also for sheep milk with azidiol, obtained a high level of doubtful results (8.6\%) compared to the samples without preservatives $(0.6 \%)$ in the Eclipse $100 \mathrm{ov}$.

Some authors recommend lengthening the incubation time of microbial tests to reduce false positive results in milk samples with azidiol. Thus, Molina et al. (1999), for goat milk with azidiol, studied different incubation periods in BRT ( 3 hours 15 minutes, 3 hours 30 minutes, and 4 hours), observing a reduction in the percentage of positive samples (15.9, 29.0 , and $36.2 \%$, respectively) compared to the time indicated by the kit manufacturer ( 3 hours). 
For cow milk, Kang and Kondo (2001) also showed and suggested lengthening the incubation period of Delvotest SP between 15 and 30 minutes to reduce the occurrence of positive results. Zaadhof et al. (2004), in a study on the viability of using microbial screening studies on sheep and goat milk, were able to reduce the percentage of false positives results by $2 \%$ in the BRT-AS Special method, lengthening the incubation period 30 minutes.

As discussed previously, false positive results in microbial screening tests can occur for a different number of reasons. Knowing the causes of the presence of false positives is necessary to try to find methodological solutions that allow their occurrence to be reduced to the minimum.

\section{REFERENCES}

Almeida da Costa, W. K., de Souza, E. L., Beltrão-Filho, E. M., Vieira, G. K. Santi-Gadelha, T., Almeida Gadelha, C, A., Franco, O. L., Ramos do Egypto Queiroga, R. C., Magnani, M. 2014. Comparative protein composition analysis of goat milk produced by the Alpine and Saanen breeds in northeastern Brazil and related antibacterial activities. PLoS ONE 9(3): e93361. doi: 10.1371/journal.pone.0093361

Althaus, R.L., Torres, A., Torres, A., Peris, C., Beltrán, M.C., Fernández, N., Molina, M.P. 2003. Accuracy of BRT and Delvotest microbial inhibition tests as affected by composition of ewe's milk. J. Food Protect. 66: 473-478.

Andrew, S. M. 2000. Effect of fat and protein content of milk from individual cows on the specificity rates of antibiotic residue screening tests. J. Dairy Sci. 83: 2992-2997.

Andrew, S.M. 2001. Effect of composition of colostrum and transition milk from Holstein heifers on specificity rates of antibiotic residue tests. J. Dairy Sci. 84: 100-106.

Antunac, M., Havranek, J., Samarzua, D., 2001. Freezing point of goat milk. Milchwissensch. 56: 14-16.

Atanasova, J., Ivanova, I. 2010. Antibacterial peptides from goat and sheep milk proteins. Biotechnology \& Biotechnological Equipment. 24: 1799-1803.

Aungier, S.P.M., Austin, F.H. A. 1987. Study of efficacy of intramammary antibiotics in the treatment of clinical mastitis. Br. Vet. J. 143: 88-90.

Aureli, P., Ferrini, A., Mannoni, V. 1996. Presumptive identification of sulphonamide and antibiotic residue in milk by microbial inhibitor test J. Food Control. 7: 165-168. 
Bangen, M., Skjerve, E., Grave, K., Soli, N.E. 1992. Prescribing of drugs for food producing animals in Norway. Information about withdrawal times. J. Vet. Pharmacol. Therapeut. 15:180-187.

Barbosa, M. 1997. Occurrence of antibiotics in ewe and goat milk. Application and suitability of various test kits. Annex IV. Report. Analytical Week. Lisboa, Portugal.

Bellivier, A.C., Gaborit, P. 2000. Lipolyse naturelle du lait de chèvre et qualité organoleptique des fromages. Renc. Rech. Rumin. 7: 315.

Beltrán, M.C., Altahus, R.L., Berruga, I., Molina, A., Molina, M.P. 2007. Microbiological methods for detection of inhibitors in goat milk. In: Acts of the 5th International Symposium on the Challenge to Sheep and Goats Milk Sectots, Alghero, Italy. pp 147149.

Beltrán, M.C., Borràs, M., Nagel, O., Althaus, R.L., Molina, M.P. 2014. Validation of receptorbinding assays to detect antibiotics in goat's milk. J. Food Prot. 96: 2737-2745.

Beltrán, M.C., Berruga, M.I., Molina, A., Althaus, R.L., Molina M.P. 2015. Performance of the current microbial tests for screening antibiotic in sheep and goat milk. Int. Dairy J. 41: 1315.

Bernard, B.L., Shingfield, K.J., Rouel, J., Ferlay, A., Chilliard, Y. 2009. Effect of plant oils in the diet on performance and milk fatty acid composition in goats fed diets based on grass hay or maize silage. Br. J. Nutr. 101: 213-224.

Bergonier, D., De Crémoux, R., Rupp, R., Lagriffoul, G., Berthelot, X. 2003. Mastitis of dairy small ruminants. Vet. Res. 34: 689-716.

Berruga, M. I., Molina, M. P., Novés, B., Román, M., Molina, A. 2007. In vitro study about the effect of several penicillins during the fermentation of yogurt made from ewe's milk. Milchwissenschaft. 62: 303-305.

Berruga, M.I., Lozoya, S., Rubio, R., Castro N., Molina, A. 2008. Estudio sobre las posibles causas de la presencia de residuos de antimicrobianos en la leche de ovino y caprino. pp 102. Ministerio de Medio Ambiente, Medio Rural y Marino.

Borràs, M., Roca, M., Althaus, R.L., Molina, M.P. 2013. Effect of storage and preservation of milk samples on the response of microbial inhibitor tests. J. Dairy Res. 80: 475-484.

Bhosale, S., Kahate, P.A., Thakare, V.M., Gubbawar, S.G. 2009. Effect lactation on physicochemical properties of local goat milk (India). Veterinary World. 2: 17-19. 
Boyazoglu, J., Hatziminaoglou, I., Morand-Fehr, P. 2005. The role of the goat in society: Past, present and perspectives for the future. Small Rumin. Res. 60: 13-23.

Carlsson, A., Björk, L. 1987. The effect of some indigenous antibacterial factors in milk on the growth of Bacillus stearothermophilus var.calidolactis. Milchwissenschaft 42: 283285.

Carlsson, Å., Björk, L. 1992. Liquid chromatography verification of tetraciclyne residues in milk and infkuence of milk fat lipolysis on the detection of antibiotic residues by microbial assays and the Charm II test. J. Food. Prot. 55: 374-378.

Carlsson, Å., Björk, L., Persson, K. 1989. Lactoferrin and lysozyme in milk during acute mastitis and their inhibitory effect in Delvotest P. J. Dairy Sci. 72: 3166-3175.

Castel, J.M., Ruiz, F.A., Mena, Y., Sánchez-Rodríguez, M. 2010. Present situation and future perspectives for goat production systems in Spain. Small Rumin. Res. 89: 207-210.

Cerbulis, J., Parks, O.W., Farrell, H.M. 1982. Composition and distribution of lipids of goats milk. J. Dairy Sci. 65: 2301-2307.

Chandal, R.C., Parry, R.M., Shahani, K.M. 1968. Lysozyme, lipase, and ribonuclease in milk of various species. J. Dairy Sci. 51: 606-607.

Chen, P.W., Chen, W. C., Mao, F.C. 2003. Increase of lactoferrin concentration in mastitic goat milk. J. Vet. Med. Sci. 66: 345-350.

Chilliard, Y., Ferlay, A., Rouel, J., Lamberet, G. 2003. A review of nutritional and physiological factors affecting goat milk lipid synthesis and lipolysis. J. Dairy Sci. 86: 1751-1770.

Chilliard, Y., Rouel, J., Leroux, C. 2006. Goat's alpha-s1 casein genotype influences its milk fatty acid composition and delta-9 desaturation ratios. Anim. Feed Sci. Technol. 131: 474-487.

Chilliard, Y., Torala, P.G., Shingfieldc, K.J., Rouela, J., Lerouxa, C., Bernarda, L. 2013. Effects of diet and physiological factors on milk fat synthesis, milk fat composition and lipolysis in the goat: A short review. Small Rum. Res. 122: 31-37.

Claeys, W.L., Verraes, C., Cardoen, S., De Block, J., Huyghebaert, A., Raes, K., Dewettinck, K., Herman, L. 2014. Consumption of raw or heated milk from different species: An evaluation of the nutritional and potential health benefits. Food Control. 42: 188-201. 
Commission Decision 97/747/EC of 27 October 1997 fixing the levels and frequencies of sampling provided for by Council Directive 96/23/EC for the monitoring of certain substances and residues thereof in certain animal products. Off. J. Eur. Comm. 1997 L303: 12-15.

Commission Decision 2002/657/EC of 12 August 2002 implementing Council Directive $96 / 23 / E C$ concerning the performance of analytical methods and the interpretation of results. Off. J. Eur. Comm. 2002 L221: 8-36.

Commission Regulation (EU) No 37/2010 of 22 December 2009 on pharmacologically active substances and their classification regarding maximum residue limits in foodstuffs of animal origin. Off. J. Eur. Union 2009 L15: 1-72.

Contreras, A., Paape, M.J., Di Carlo, A.L., Miller, R.H., Rainard, P. 1997. Evaluation of selected antibiotic residue screening tests for milk from individual goats. J. Dairy Sci. 80: 1113-1118.

Contreras, A., Paape, M.J., Miller, R.H. 1999. Prevalence of subclinical intramammary infection caused by Staphylococcus epidermidis in a commercial dairy goat herd. Small Rum. Res. 31: 203-208.

Contreras, A., Sierra, D., Sánchez, A., Corrales, J.C., Marco, J.C., Paape, M.J., Gonzalo, C. 2007. Mastitis in small ruminants. Small Rumin. Res. 68: 145-153.

Cullor, J.S. 1992. Test for identifying antibiotic residues in milk: how well do they work? Vet. Med. 87: 1235-1241.

Council Regulation (EEC) No 2377/90 laying down a Community procedure for the establishment of maximum residue limits of veterinary medicinal products in foodstuffs of animal origin. Off. J. Eur. Comm. 1990 L224: 1-8.

Council Directive 96/23/EC of 29 April 1996 on measures to monitor certain substances and residues there of in live animals and animal products and repealing Directives 85/358/ECC and 86/469/ECC and Decisions 89/187/ECC and 91/664/ECC.Off. J. Eur. Comm. 1996 L125: 10-32.

CRLs. 2010. Guidelines for the validation of screening methods for residues of veterinary medicines. Community Reference Laboratories for residues. Available at http://ec.europa.eu/food/food/chemicalsafety/residues/lab_analysis_en.htm (Last update: 20-01-2010). 
Debackere, M. 1995. Pharmacokinetics and pharmacodynamics of antimicrobials in relation to their residues in milk. pp 41. In Acts: Symposium on Residues of Antimicrobial Drugs and other Inhibitors in Milk, Kiel, Germany.

Demoly, P., Romano, A. 2005. Update on beta-lactam allergy diagnosis. Curr. Allergy Asthm. R. 5: 9-14.

Deeth, H.C. 2006. Lipoprotein lipase and lipolysis in milk. Int. Dairy J. 16: 555-562.

Delgado-Pertiñez, M., Alcalde, M.J., Guzmán-Guerrero, J.L., Castel, J.M., Mena, Y., Caravaca, F. 2003. Effect of hygiene-sanitary management on goat milk quality in semiextensive systems in Spain. Small Rumin. Res. 47: 51-61.

Directive 2001/82/EC of the European Parliament and of the Council of 6 November 2001 on the Community code relating to veterinary medicinal products. Off. J. Eur. Comm. 2001 L311: 1-66.

Directive 2004/28/EC of the European Parliament and of the Council of 31 March 2004 amending Directive 2001/82/EC on the Community code relating to veterinary medicinalproducts. Off. J. Eur. Union. 2004 L136: 58-84.

Dračková, M., Borkovcová, I., Janštová, B., Naiserová, M., Přidalová, H., Navrátilová, P., Vorlová, L. 2009. Determination of lactoferrin in goat milk by HPLC method. Czech J. Food Sci. 27: 102-104.

Egan, J., Meaney, W.J. 1984. The inhibitory effect of mastitic milk and colostrums on test methods used for antibiotic detection. Ir. J. Food Sci. 8: 115-120.

Eknaes, M., Kolstad, K., Volden, H., Hove, K. 2006. Changes in body reserves and milk quality throughout lactation in dairy goats. Small Rumin. Res. 63: 1-11.

EMA. 2014. European Medicines Agency, European Surveillance of Veterinary Antimicrobial Consumption, 2014. 'Sales of veterinary antimicrobial agents in 26 EU/EEA countries in 2012'. (EMA/333921/2014).

Fabre, J.M., Moretain, J.P., Ascher, F., Brouillet, O., Berthelot, X. 1995. Main causes of inhibitors in milk. A survey in one thousand French dairy farms. In: Residues of Antimicrobial Drugs and other Inhibitors in Milk. IDF S.I. 9505: 27-31. International Dairy Federation, Brussels, Belgium.

FAO and IDF. 2011. Guide to good dairy farming practice. Animal Production and Health Guidelines. No. 8. Rome, Italy. 
FAOSTAT, 2012. Food and Agriculture Organization of the United Nations, Available at: http//faostat.fao.org (Accessed: 21-5-2013).

Ferrini, M.A., Trenta, S., Mannoni, S., Rosati, R., Coni, E. 2010. Depletion of long-acting ampicillin in goat milk following intramuscular administration. J. Agri.I Food Chem. 58: 12199-12203.

Goetsch, A.L., Zeng, S.S., Gipson, T.A. 2011. Factors affecting goat milk production and quality. Small Rumin. Res. 101: 55-63.

Gonzalo, C., Tardaguila, J.A., De la Fuente, L.F., San Primitivo, F. 2004. Effects of selective and complete dry therapy on prevalence of intramammary infection and on milk yield in the subsequent lactation in dairy ewes. J. Dairy Res. 71: 33-38.

Gonzalo, C., De Garnica, M.L., García-Jimeno, M.C., Asensio, J.A. 2012. Bulk milk antibiotic residue occurrence, somatic cell count and total bacterial count in dairy goat flocks. XI International Conference on Goats (IGA). Book of Abstracts. Gran Canaria, Spain.

Greppi, G.F., Roncada, P., Fortin, R. 2008. Protein components of goat's milk. pp 71-94. In: Pulina, G., Cannas, A. (Eds). Dairy goats feeding and nutrition. CAB International. Bologna, Italy.

Grundwald L., Petz M. 2003. Food processing effects on residues: penicillins in milk and yogurt. Anal. Chim. Acta. 483: 73-79.

Guzmán, M.A., Salinas, J., Paola, L., Afani, A. 2004. Allergy to betalactams. Rev. Chil. Infect. 21: 285-298.

Haenlein, G.F.W. 1993. Producing quality goat milk. Int. J. Anim. Sci. 8: 85-85.

Haenlein, G.F.W. 2004. Goat milk in human nutrition. Small Rumin. Res. 51: 155-163.

Hiss, S., Meyer, T., Sauerwein, H. 2008. Lactoferrin concentrations in goat milk throughout lactation. Small Rumin. Res. 80: 87-90.

IDF. 2013. IDF Guide to Prudent Use of Antimicrobial Agents in Dairy Production. International Dairy Federation, Brussels, Belgium.

IDF. 2014. Detecting antibiotic residues in milk-Guidance on the application of screening and confirmatory methods in integrated dairy chain management. Bulletin No 474. International Dairy Federation, Brussels, Belgium. 
IFAH-Europe. 2012. IFAH-Europe Annual Report 2012. Available at: http://www.ifaheurope.org/ifah-media/publications/125-ifah-europe-annual-report2012.html?catid=56

ISO/IDF. 2002. Guidelines for the standardized description of immuno- or receptor assays for the detection of antimicrobial residues. IDF Standard №188:2002. International Dairy Federation, Brussels, Belgium.

ISO/IDF 2003. Milk and milk products- Guidelines for a standardized description of microbial inhibitor tests. IDF Standard №183:2003, Brussels, Belgium: International Dairy Federation.

Kang, J.H., Kondo, F. 2001. Occurrence of false-positive results of inhibitor on milk samples using the Delvotest SP assay. J. Food Prot. 64: 1211-121Kemper N. 2008. Review: Veterinary antibiotics in the aquatic and terrestrial environment. Ecological indicators. 8: $1-13$.

Kang, J.H., Jin, J.H., Kondo, F. 2005. False-positive outcome and drug residue in milk samples over withdrawal times. J. Dairy Sci. 88: 908-913.

Karzis, J., Donkin, E.F., Petzer, I.M. 2007. Intramammary antibiotics in dairy goats: effect of stage of lactation, parity and milk volume on withdrawal periods, and the effect of treatment on milk compositional quality. Onderstepoort J. Vet. Res. 74: 243-249.

Kemper N. 2008. Veterinary antibiotics in the aquatic and terrestrial environment. Ecol. Indic. 8: $1-13$

Korhonen, H., Kaartinen, L. 1995. Changes in the composition of milk induced by mastitis. In: The bovine udder and mastitis. Sandholm M., Honkanen-Buzalski T., Kaartinen L., Pyörälä S. Ed. University of Helsinki, Faculty of Veterinary Medicine, Helsinki, Finland. pp 76-82.

Kouřimská, L., Vondráčková, E., Fantová, M., Nový, P., Nohejlová, L., Michnová, K. 2014. Effect of feeding with algae on fatty acid profile of goat's milk. Scientia Agriculturae Bohemica. 45: 162-169.

Leitner, G., Merlin, U., Silanikova, N. 2004. Changes in milk composition as affected by subclinical mastitis in goats. J. Dairy Sci. 87: 1719-1726.

Lindmark-Mansson, H., Fondén, R., Pettersson, H.E. 2003. Composition of Swedishdairy milk. Int. Dairy J. 13: 409-42. 
López, M.B., Jordan, M.J., Granados, M.V., Fernández, J.C., Castillo, M., Laencina, J. 1999. Viscosity changes during rennet coagulation of Murciano-Granadina goat milk. Int. J. Dairy Technol. 52: 102-106.

MAGRAMA. 2012. Ministerio de Agricultura, Alimentación y Medios Ambiente. Caracterización del sector ovino y caprino en España año 2012. http://www.magrama.gob.es/es/ganaderia/temas/produccion-y-mercadosganaderos/CARACTERIZACI\%C3\%93N_DEL_SECTOR_OVINO_Y_CAPRINO_EN_ES PA\%C3\%91A_2013_tcm7-271704.pdf (Accessed: 03-5-13).

Marco, J.C., Extramiana, A.B, Sánchez, A., García, I., Contreras, A. 2001. Resultados sobre inhibidores en muestras de leche de tanque de productores de ganado caprino. pp. 225229. Actas de V Jornadas Internacionales de la Sociedad Española de Ovinotecnia y Caprinotecnia, Sevilla, España.

Martínez-Carballo, E., González-Barreiro, C., Scharf, S., Gans, O. 2007. Environmental monitoring study of selected veterinary antibiotics in animal manure and soils in Austria. Environmental Pollution. 148: 570-579.

Mäyrä-Mäkinen, A. 1990. T-101 test for antibiotic residues in milk. Scand. Dairy Inf. 2: 38-39. Mäyrä-Mäkinen, A. 1995. Technological significance of residues for the dairy industry. pp.136-143. Proceedings of IDF symposium on residues of antimicrobial drugs and other inhibitors in milk. Kiel, Germany, August 28-31.

McDougall, S., Annis, F. 2005. Efficacy of antibiotic treatment at drying-off in curing existing infections and preventing new infections in dairy goats. pp. 523-528. In: Hogeveen, $\mathrm{H}$. (Ed.). Mastitis in Dairy Production. Wageningen Academic Press Publishers, the Netherlands.

Mena, Y., Delgado- Pertiñez, M., Alcalde, M.J., Castel, J.M., Guzmán, J.L., Caravaca, F., Ramírez, E., Gousse, S. 1999. Study of the goat production system and the quality of milk produced in the Sierra Norte of Seville (Spain). In: Rubino, R., Morand-Fehr, P. (Eds.) Production systems and product quality in sheep and goats. Options Méditerranéennes. 46: 201-205.

Mena Y., Castel J.M., Caravaca F.P., Guzmán J.L., González P. 2005. Situación actual, evolución y diagnóstico de los sistemas semiextensivos de producción caprina en Andalucía Centro-Occidental. Ed. Consejería de Agricultura y Pesca. Junta de Andalucía. Sevilla, Spain. 
Menzies, P.I., Ramanoon, S.Z. 2001. Mastitis of sheep and goats. Vet. Clin. North Am. Food Anim. Pract. 17: 333-358.

Merin, U., Rosenthal, I., Bernstein, S., Popel, G. 1985. The effect of residues of detergents and detergents-sanitizers on the performance of antibiotic test and the organoleptic quality of milk. Le Lait. 65: 163-167.

Mitchell, J.M., Grifiths, M.W., McEwen, S.A., McNab, W.B., Yee, A.J. 1998. Antimicrobial drug residues in milk and meat: causes, concerns, prevalence, regulations, tests, and test performance. J. Food Prot. 61: 742-756.

Mmbengwa, V.M., Schwalbach, L.M., Greyling, J.P.C., Fair, M.D. 2000. Milk production potential of South African Boer and Nguni goats. S. Afr. J. Anim. Sci. 30: 76-77.

Montero, A., Althaus, R. L., Molina, A., Berruga, I., Molina, M.P. 2005. Detection of antimicrobial agents by specific microbiological method (Eclipse 100) for ewe milk. Small Rum. Res. 57: 229-237.

Molina, M.P., Segura, C., Luján, A., Althaus, R.L., Peris, C. 1999. Influencia del calentamiento y del tiempo de incubación sobre la respuesta del método BRT en la leche de cabra. Ile, Revista Mensual de las Industrias Lácteas Españolas. 241: 37-40.

Molina, M.P., Althaus, R.L., Balasch, S., Torres, A., Peris, C., Fernandez, N. 2003. Evaluation of screening test for detection of antimicrobial residues in ewe milk. J. Dairy Sci. 86: 1947-1952.

Morand-Fehr, P., Owen, E., Giger-Reverdin, S. 1991. Feeding behaviour of goats at the trough. pp. 3-24. In: Morand-Fehr, P. (Ed.) Goat Nutrition. Pudoc Wageningen, Wageningen, Holland.

Morgan, F., Gaspard, C.E. 1999. Influence des cellules somatiques sur les qualités technologiques du lait de chèvre et sur les caractéristiques des fromages de chèvre. Renc. Rech. Ruminants 6: 317.

Morgan, F., Massouras, T., Barbosa, M., Roseiro, L., Ravasco, F., Kandarakis, I., Bonnin, V., Fistakoris, M., Anifantakis, E., Jaubert, G., Raynal-Ljutovac, K. 2003. Characteristics of goat milk collected from small and medium enterprise in Greece. Portugal and France. Small Rumin. Res. 47: 39-49.

Moreno-Indias, I., Sánchez-Macías, D., Castro, N., Morales-delaNuez, A., HernándezCastellano L.E, Capote, J., Argüello, A. 2012. Chemical composition and immune status 
of dairy goat colostrum fractions during the first $10 \mathrm{~h}$ after partum. Small Rumin. Res. 103: $220-224$.

Mourot, D., Loussourons, S. 1981. Sensibilité des ferments lactiques aux antibiotiques utilisés en médecine vétérinaire. Rec. Med. Vét. 157: 175-177.

Nudda, A., Battacone, G., Usai, M.G., Fancellu, S., Pulina, G. 2006. Supplementationwith extruded linseed cake affects concentrations of conjugated linoleic acid and vaccenic acid in goat milk. J. Dairy Sci. 89: 277-282.

Nudda, A., Battacone, G., Atzori, A.S., Dimauro, C., Rassu, S.P.G., Nicolussi, P., Bonelli, P., Pulina, G. 2013. Effect of extruded linseed supplementation on blood metabolic profile and milk performance of Saanen goats. Animal. 7: 1464-1471.

Oliver, S.P., Duby, R.T., Prange, R. W., Tritschler, J.P. 1984. Residues in colostrum following antibiotic dry cow therapy. J. Dairy Sci. 67: 3081-3084.

Paape, M.J., Poutrel, B., Contreras, A., Marco, J.C., Capuco, A.V. 2001. Milk somatic cells and lactation in small ruminants. J. Dairy Sci. 84: 237-244.

Packham, W., Broome, M.C., Limsowtin, G.K.Y., Roginski, H. 2001. Limitations of standard antibiotic screening assays when applied to milk for cheesemaking. Aust. J. Dairy Technol. 56: 15-18.

Park, Y.W. 1994. Hypo-allergenic and therapeutic significance of goat milk. Small Rumin. Res. 14: 151-159.

Park, Y.W. 2005. Goat milk: composition, characteristics. pp. 474-477. Encyclopedia of Animal Science. Pond, W.G., Bell, N. (Eds.). Marcel Dekker, Inc.New York.

Park, Y.W. 2006. Goat milk: chemistry and nutrition. pp. 34-58. In: Handbook of Milk of NonBovine Mammals. Park, Y.W., Haenlein, G.F.W. (Eds.). Blackwell Publishers. Ames, lowa and Oxford, England.

Park, Y.W., Juárez, M., Ramos, M., Haenlein, G.F.W. 2007. Physico-chemical characteristics of goat and sheep milk. Small Rumin. Res. 68: 88-113.

Parodi, P.W. 2002. Health benefits of conjugated linoleic acid. Food Ind. J. 5: 222-259.

Pengov, A., Kirbis, A. 2009. Risks of antibiotic residues in milk following intramammary and intramuscular treatments in dairy sheep. Anal. Chim. Acta. 637: 13-17. 
Phillips, I., Casewell, M., Cox, T., De Groot, B., Friis, C., Jones, R. 2004. Does the use of antibiotics in food animals pose a risk to human health? A critical review of published data. J. Antimicrob. Chemother. 53: 28-52.

Pirisi, A., Lauret, A., Dubuef, J.P. 2007. Basic and incentive payments for goat and sheeo milk in relation to quality. Small Rumin. Res. 68: 167-178.

Prosser, C.G., McLaren, R.D., Frost, D., Agnew, M., Lowry, D.J. 2008. Composition of the non-protein nitrogen fraction of goat whole milk powder and goat milk-based infant and follow-on formulae. Int. J. Food Sci. Nutr. 59: 123-133.

Rawya, A.A.S., Ahmed, K.A. 2014. Physicochemical characteristics of Damascus (Shami) Cyprus goats milk in different lactation periods. Int. J. Lib. Arts Social Sci. 2: 67-72.

Raynal-Ljutovac, K., Gaborit, P., Lauret A. 2005. The relationship between quality criteria of goat milk, its technological properties and the quality of the final products. Small Rumin. Res. 60: 167-177.

Raynal-Ljutovac, K., Pirisi, A., De Crémoux, R., Gonzalo, C. 2007. Somatic cells of goat and sheep milk: Analytical, sanitary, productive and technological aspects. Small Rumin. Res. 68: 126-144.

Raynal-Ljutovac, K., Lagriffoul, G., Paccard, P., Guillet, I., Chilliard, Y. 2008. Composition of goat and sheep milk products: An update. Small Rumin. Res. 79: 57-72.

Real Decreto 217/2004, de 6 de febrero de 2004 por el que se regulan la identificación y registro de los agentes, establecimientos y contenedores que intervienen en el sector lácteo, y el registro de los movimientos de la leche cruda de vaca. $\mathrm{BOE}, 19$ de febrero de 2004. 43: 7802-7806.

Real Decreto 1728/2007, de 21 de diciembre, por el que se establece la normativa básica de control que deben cumplir los operadores del sector lácteo y se modifica el Real Decreto $217 / 2004$, de 6 de febrero, por el que se regulan la identificación y registro de los agentes, establecimientos y contenedores que intervienen en el sector lácteo, y el registro de los movimientos de la leche. Boletin Oficial del Estado (B.O.E.), Madrid, España, num. 15, Jueves 17 enero 2008. 15: 3508-3519.

Real Decreto № 752/2011 de 27 de mayo, por el que se establece la normativa básica de control que deben cumplir los agentes del sector de leche cruda de oveja y cabra. Boletín Oficial del Estado, 9 de Junio de 2011. 137: 58609-58630 
Reinemann, D.J., Wolters, G.M.V.H., Billon, P., Lind, O., Rasmussen, M.D. 2003. Review of practices for cleaning and sanitation of milking machines. IDF Bull 381: 32-50. International Dairy Federation, Brussels, Belgium.

Regulation (EEC) No 2377/90 and amending Directive 2001/82/EC of the European Parliament and of the Council and Regulation (EC) No 726/2004 of the European Parliament and of the Council laying down a Community procedure for the establishment of maximum residue limits of veterinary medicinal products in foodstuffs of animal origin. Off. J. Eur. Union 2009 L152: 11-22.

Regulation (EC) No 178/2002 of the European Parliament and of the Council of 28 January 2002 laying down the general principles and requirements of food law, establishing the European Food Safety Authority and laying down procedures in matters of food safety. Off. J. Eur. Comm 2002 L31: 1-24.

Regulation (EC) No 852/2004 of the European Parliament and of the Council of 29 April 2004 on the hygiene of foodstuffs. Off. J. Eur. Union 2004 L139: 1-54.

Regulation (EC) No 853/2004 of the European Parliament and of the Council of 29 April 2004 laying down specific hygiene rules for on the hygiene of foodstuffs. Off. J. Eur. Union 2004 L139: 55-05.

Regulation (EC) No 854/2004 of the European Parliament and of the Council of 29 April 2004 laying down specific rules for the organisation of official controls on products of animal origin intended for human consumption. Off. J. Eur. Union 2004 L139: 206-320.

Regulation (EC) No 882/2004 of the European Parliament and of the Council of 29 April 2004 on official controls performed to ensure the verification of compliance with feed and food law, animal health and animal welfare rules. Off. J. Eur. Union 2004 L139: 1-141.

Regulation (EC) No 470/2009 of the European Parliament and of the Council of 6 May 2009 laying down Community procedures for the establishment of residue limits of pharmacologically active substances in foodstuffs of animal origin, repealing Council Regulation (EEC) No 2337/90 and amending Directive 2001/82/EC of the European Parliament and of the Council and Regulation (EC) No 726/2004 of the European Parliament and of the Council laying down a Community procedure for the establishment of maximum residue limits of veterinary medicinal products in foodstuffs of animal origin. Off. J. Eur. Union 2009 152: 11-22. 
Remeuf, F., Lenoir, J. 1986. Relationship between the physico- chemical characteristics of goat milk and its rennetability. FIL-IDF Bulletin 202:68-72. International Dairy Federation, Brussels, Belgium.

Reybroeck, W. 2010. Screening for residues of antibiotics and chemotherapeutics in milk and honey. Thesis submitted in fulfillment of the requirements for the degree of Doctor (Ph.D.) in Veterinary Sciences, Faculty of Veterinary Medicine, Ghent University: 1-295. ISBN 978-90-5864-244-8.

Reybroeck, W., Ooghe, S. 2012. FASFC acceptance criteria for microbiological inhibitor tests: fulfillment by new tests. pp 197-201. In: Schilt R, editor. Proceedings of the EuroResidue VII Conference on residues of veterinary drugs in food, Egmond aan Zee, The Netherlands, May 14-16.

Reybroeck, W., De Vleeschouwer, M., Marchand, S., Sinnaeve, D., Heylen, K., De Block, J., Madder, A., Martins, J., Heyndrickx, M. 2014. Cyclic lipodepsipeptides produced by Pseudomonas spp. naturally present in raw milk induce inhibitory effects on microbiological inhibitor assays for antibiotic residue screening. PLoS ONE 9 (5): e98266. doi:10.1371/journal.pone.0098266.

Roca, M., Castillo, M., Martí, P., Althaus, R.L., Molina, M.P. 2010. Effect of heating on the stability of quinolones in milk. J. Agric. Food Chem. 58: 5427-5431.

Romero, T., Beltrán, M.C., Rodríguez, M., Martí De Olives, A., Molina, M.P. 2013. Short communication: Goat colostrum quality: Litter size and lactation number effects. J. Dairy Sci. 96: 7526-7531.

Salomskiene, J., Macioniene, I., Zvirdauskiene, R., Jonkuviene, D. 2013. Impact of the residues of detergents and disinfectants used in dairy farms on the results of inhibitor tests for raw mik. Adv. Biosci. Biotechnol. 4: 266-277.

Salvador, A., Martínez, Gonzalo., Alvarado, C., Hahn, M. 2006. Composición de leche de cabras mestizas Canarias en condiciones tropicales. Zootecnia Trop. 24: 307-320.

Sanders, P., Bousquet-Melou, A., Chauvin, C., Toutain, P.L. 2011. Utilisation des antibiotiques en élevage et enjeux de santé publique (Use of antibiotics in animal and public health issues). INRA Prod. Anim. 24: 199-204.

Sánchez, M., López, D., Santos, R., Martín, C. 2002. Situación de la Producción de leche de cabra en Espana (Status milk goat production in Spain). Mundo ganadero. 164: 36-43. 
Sánchez-Macías, D., Moreno-Indias, I., Castro, N., Morales-delaNuez, A., Argüello, A., 2014. From goat colostrum to milk: Physical, chemical, and immune evolution from partum to 90 days postpartum. J. Dairy Sci. 97: 10-16.

Sanz Ceballos, L., Ramos Morales, E., de la Torre Adarve, G., Díaz Castro, J., Pérez Martínez, L., Sanz Sampelayo, M.R. 2009. Composition of goat and cow milk produced under similar conditions and analyzed by identical methodology. J. Food Compost. 22: 322-329.

Schiffmann, A.P., Schütz, M., Wiesner, H. 1992. False negative and positive results in testing for inhibitory substances in milk. Factors influencing the brilliant black reduction test (BRT). Milchwissenschaft. 47: 770-772.

Sébédio, J.L., Gnaedig, S., and Chardigny, J.M. 1999. Recent advances in conjugated linoleic acid research. Curr. Opin. Clin. Nutr. Metabolic. Care. 2: 499-506.

Selvaggi, M., Laudadio, V., Dario, C., Tufarelli, V. 2014. Major proteins in goat milk: an updated overview on genetic variability. Mol Biol Rep. doi 10.1007/s11033-013-2949-9.

Shuren, G., Heeschen W. 1993. Detection of tetracyclines in milk by Bacillus cereus microlitre test with indicator. Milchwissenschaft. 48: 259-263.

Sierra, D., Sánchez, A., Contreras, A., Luengo, C., Corrales, J.C., de la Fe, C., Guirao, I., Morales, C.T., Gonzalo, C. 2009a. Detection limits of four antimicrobial residue screening test for $\beta$-lactams in goat's milk. J. Dairy Sci. 92: 3585-3591.

Sierra, D., Contreras, A., Sánchez, A., Luengo, C., Corrales, J.C., Morales, C.T., De la Fe, C., Guirao, I., Gonzalo, C. 2009b. Short communication: Detection limits of non- $\beta$-lactam antibiotics in goat's milk by microbiological residues screening tests. J. Dairy Sci. 92: 4200-4206.

Silanikove, N., Leitner, G., Merin, U., Prosser, C.G. 2010. Recent advances in exploiting goat's milk: Quality, safety and production aspects. Small Rumin. Res. 89: 110-124.

Sordillo, L.M., Streicher, K.L. 2002. Mammary gland immunity and mastitis susceptibility. J. Mam Gland Biol Neopl. 7: 135-146.

Soryal, K., Beyene, F.A., Zeng, S.S., Bah, B., Tesfai, K. 2005. Effect of goat breed and milk composition on yield, sensory quality, fatty acid concentration of soft cheese during lactation. Small Rumin. Res. 58: 275-281.

Stead, S.L., Ashwin, H., Richmond, S.F., Sharman, M., Langeveld P.C., Barendse, J.P., Stark, J., Keely, B.J. 2008. Evaluation and validation according to international standards 
of the Delvotest SP-NT screening assay for antimicrobial drugs in milk. Int. Dairy J. 18: 311.

Storry, J.E., Grandison, A.S., Millard, D. 1983. Chemical composition and coagulating properties of renneted milks from different breeds and species of ruminants. J. Dairy Res. 50: 215-229.

Strzałkowska, N., Jóźwik, A., Bagnicka, E., Krzyżewski, J., Horbańczuk, K., Pyzel, B., Horbańczuk, J.O. 2009. Chemical composition, physical traits and fatty acid profile of goat milk as related to the stage of lactation. Anim. Sci. Pap. Rep. 27: 311-320.

Tollefson, L., Karp, B.E. 2004. Human health impact from antimicrobial use in food animals. Médecine et Maladies Infectieuses. 34: 514-521.

Trobos, M., Jakobsen, L., Olsen, K.E. 2008. Prevalence of sulphonamide resistance and class 1 integron genes in Escherichia coli isolates obtained from broilers, broiler meat, healthy humans and urinary infections in Denmark. Int. J. Antimicrob. Ag. 32: 367-369.

Trobos, M., Lester, C.H., Olsen, J.E., Frimodt-Moller, N., Hammerum, A.M. 2009. Natural transfer of sulphonamide and ampicillin resistance between Escherichia coli residing in the human intestine. J. Antimicrob. Chemother. 63: 80-86.

Verdier-Metz, I., Coulon, J.B., Pradel, P. 2001. Relationship between milk fat and protein contents and cheese yield. Anim. Res. 50: 365-371.

Wilson, M., Tam, M. 2010. Raising Awareness for prudent use of antibiotics in animals. Position paper of the global alliance for the prudent use of antibiotics (APUA). In: WHO Expert meeting, Development of a policy-oriented guidance booklet for the European countries on antimicrobial resistance in a food safety perspective, Rome, Italy, November 11-12.

Ying, C.W., Wang, H.T., Hsu, J.T. 2002. Relationship of somatic cell cpunt, physical, chemical and enzymatic properties to the bacterial standard plate count in dairy goat milk. Livest. Prod. Sci. 74: 63-77.

Žan, M., Stibil, J.V., Rogel, J.I. 2006. Milk fatty acid composition of goats grazing on alpine pasture. Small Rumin. Res. 64: 45-2.

Zapico, P., Gaya, P., Nunez, M., Medina, M., De-Paz, M. 1991. Influence of breed, animal and days of lactation on lactoperoxidase system components in goat milk. J. Dairy Sci. 74: 783-787. 
Zaadhof, K.J., Schulze, S., Märtelbauer, E. 2004. Applicability of various microbial inhibitor tests as screening tests fort he presence of antimicrobials in goat and ewe milk. Milchwissenschaft. 59: 179-183.

Zeng, S.S., Escobar, E.N., Brown-Crowder, I. 1996. Evaluation of screening tests for detection of antibiotics in goat milk. Small Rumin. Res. 21: 155-160.

Zeng, S.S., Popham, T. Escobar, E.N. 1999. Seasonal variation of somatic cell count and chemical composition in bulk tank goat milk. Dairy Food Environ. Sanit. 19: 685-690.

Zeng, S.S., Chen, S.S., Bah, B., Tesfai, K. 2007. Effect of extended storage on microbiological quality, somatic cell count and composition of raw goat milk on farm. J. Food Prot. 70: 1281-1285.

Zhang, R.H., Mustafa, A.F., Zhao X. 2006. Effects of feeding oilseeds rich in linoleic and linolenic fatty acids to lactating ewes on cheese yield and on fatty acid composition of milk and cheese. Anim. Feed Sci. Tech. 127: 220-233.

Zorraquino, M.A., Roca, M., Fernández, N., Molina, M.P., Althaus, R.L. 2008. Heat inactivation of $\beta$-lactam antibiotic in milk. J. Food Prot. 71: 1193-1198.

Zorraquino, M.A., Althaus, R.L., Roca, M., Molina, M.P. 2009. Effect of heat treatments on aminoglycosides in milk. J. Food Prot. 72: 1338-1341.

Zorraquino, M.A., Althaus, R.L., Roca, M., Molina, M.P. 2011. Heat treatments effects on the antimicrobial activity of macrolide and lincosamide antibiotics in milk. J. Food Prot. 74: 311-315.

Zvirdauskiene, R., Salomskiene, J. 2007. An evaluation of different microbial and rapid test for determining inhibitors in milk. Food Control. 18: 541-547. 

Chapter 2

Objectives 

The presence of drug residues in milk could possibly cause adverse effects on consumers' health, and has negative repercussions for the dairy industry. European legislation (Regulation (EC) No 853/2004) establishes the criteria for the hygiene of foodstuffs of an animal origin, including milk and dairy products of different species, and specifies the mandatory control for the presence of antibiotic residues in milk.

For the screening of milk on antibiotic residues, several commercial methods with a different analytical basis are available. Microbial inhibitor tests are routinely applied in control laboratories, as they are inexpensive, user-friendly, and able to detect a wide variety of antimicrobials with a large sample throughput. A limitation of these tests is that they are nonspecific and they may be affected by substances other than antimicrobials that could inhibit the growth of the test microorganism. Thus, substances derived from colostrum and residues of cleaning and antiparasitic agents might interfere with the test. Additionally, aspects related to the composition of the goat milk, such as concentration of fat, protein, natural inhibitors, somatic cell count and other components may affect the results of microbial inhibitor tests by producing false positive results.

The occurrence of positive results implies non-commercialisation of the milk and may also lead to fines and economic losses for farmers and dairies. It is therefore essential to be absolutely certain that a positive result is due to the presence of antibiotics (possibly noncompliant) when screening steps are carried out.

The general aim was to study the interference of microbial inhibitor tests for screening antibiotics of different contaminant substances in goat milk, as well as studying the effect of certain characteristics of the milk itself on microbial inhibitor test response.

With this aim, the following specific objectives were defined:

1. To analyse the effect of the presence of colostrum

2. To study the effect of presence of detergents and disinfectants

3. To determine the interferences by antiparasitic drugs

4. To evaluate the influence of goat milk quality

These objectives were researched through various experiments that are presented in the "Results" section in the form of four chapters, corresponding to each of the four established objectives. 



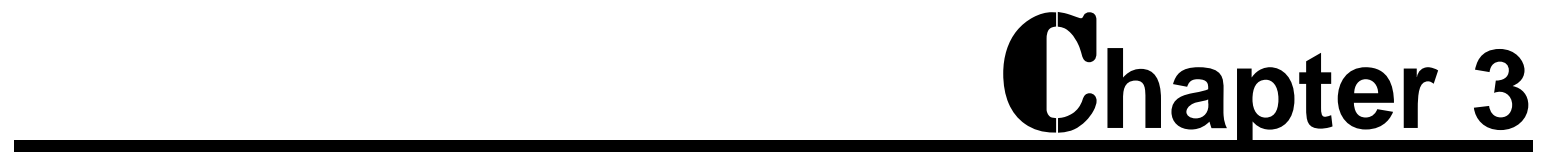

Presence of colostrum on microbial screening methods for antibiotic detection in goat milk 



\title{
Effect of the presence of colostrum on microbial screening methods for antibiotic detection in goat milk
}

\begin{abstract}
The aim of this work was to study the response of microbial tests used for the detection of antibiotics in colostrum and in colostrum-containing goat milk. For this purpose, colostrum and milk samples were collected from 43 Murciano-Granadina goats every 12 hours during the first 7 days of lactation. All samples were analysed by the microbial inhibitor tests BRT MRL, Delvotest SP-NT MCS and Eclipse 100. The results show that the tests were not suitable for the analysis of goat colostrum because they presented a high percentage of doubtful and positive results for samples of the first 24 hours post-partum. Only the Delvotest SP-NT MCS could be used successfully for samples from 36 hours postpartum onwards, as it shows a very high specificity, while this was not obtained for BRT MRL and Eclipse 100 until 96 hours post-partum. According to the logistic regression model, the occurance of non-compliant results for these screening tests is mainly related to the high protein content of colostral secretions. Furthermore, to study the influence of the presence of colostrum on goat milk, antibiotic and colostrum-free farm tank milk was used, to which different concentrations $(n=12)$ of colostrum obtained at different post-partum hours $(12,24$, 36 and 48 hours) were added. Positive results appeared in BRT MRL for milk mixed with relatively low concentrations of colostrum collected at 12 to 24 hours post-partum $(7.5-10 \%$, respectively), while in the Delvotest SP-NT MCS and Eclipse 100 non-compliant results only occurred for milk with high concentrations $(\geq 35 \%)$ of colostrum for both time points. Moreover, high concentrations $\geq 20 \%$ of colostrum from 36 to 48 hours are needed to affect the BRT MRL. Low concentrations of colostrum in milk that may cause non-compliant results can be avoided if good farming practices for the identification and separation of goats at the beginning of lactation are respected.
\end{abstract}

Keywords: colostrum, inhibitors, goat milk, screening methods. 


\section{Introduction}

Colostrum is the first mammary secretion after partum, which provides the nutrients and the passive immunity to newborn that allows facing possible infections (Clare et al., 2003; Keskin et al., 2007; Nowak and Poidron, 2006). Although colostrum contains in comparison to goat milk more protein and fat and a higher number of somatic cells (MorenoIndias et al., 2012; Romero et al., 2013), the major importance of colostrum is the higher presence of immunoglobulins as passive maternal antibodies and the elevated concentration of other biologically active components such as lactoferrin and lysozyme (Levieux et al., 2002; Hiss et al., 2008).

Colostrum is considered a product of animal origin produced in a similar way as raw milk, therefore, could be considered as presenting a risk to human health as well; but this product is not covered by the definition of raw milk. Following legislation (Regulation (EC) No 853/2004 and Regulation (EC) No 1662/2006) and the definition of milk (Anonymous, 1908; Spanish Decree 2484/1967), the raw milk intended for human consumption must not contain colostrum.

Regulation (EC) No 853/2004 lays down specific rules on the hygiene of food of animal origin for food business operators producing raw milk and dairy products and colostrum and colostrum-based products intended for human consumption, therefore these products are subject to official requirements. Regarding the control of antibiotics in products of animal origin including raw milk, maximum residue limits (MRLs) have been established for antimicrobial substances by the European Union (Commission Regulation (EU) No $37 / 2010)$.

Intramammary antibiotics used as dry-off treatment at the end of lactation, to cure mastitis and reduce the number of new infections (Fox et al., 1992; Lohuis et al., 1995) are among the possible causes for the presence of antibiotics in colostrum and milk after partum. Some authors consider dry-goat therapy a useful tool for managing milk quality in dairy goats (McDougall and Anniss, 2005). Also, it should mentioned that in caprine livestock specialised in milk production, the artificial rearing of goat kids and milking goats immediately after delivery frequently occurs (Argüello et al., 2004). Consequently, the presence of antibiotics in colostrum could pose a risk for the health of goat kids and also, increases the probability to be found as residues in raw milk.

The control of antibiotics in milk is of great importance, because their presence can cause serious public health problems, such as allergies, digestive problems among others (Demoly and Romano, 2005; Sanders et al., 2011). The presence of antimicrobials can also 
generate technological problems in the manufacture of fermented dairy products such as cheese and yoghurt (Packham et al., 2001; Berruga et al., 2011).

Currently, several commercial methods to detect antibiotics are available (IDF, 2010). The microbial inhibitor tests widely used in control laboratories are generally based on the inhibition of the growth of the microorganism Geobacillus stearothermophilus var. calidolactis, and their results are qualitatively interpreted by a colour change (yellow: negative and blue/purple: positive). Microbial inhibitor tests are not specific for a particular group or family of antibiotics. Due to of their lack of specificity, inhibitor tests may be affected by different substances that could inhibit microbial growth, such as natural inhibitors of milk, somatic cell count, preservatives, etc., which can cause false-positive results (Carlsson et al., 1989; Andrew, 2001; Molina et al., 2003). Inhibitor tests have been developed for testing cow milk, but are used for the analysis of milk from other species, such as goats. Some authors have studied the response of microbial methods for goat milk in relation to the occurrence of false-positive results (Zeng et al., 1996; Ham et al., 2008; Comunian et al., 2010; Beltrán et al., 2015). Legislation does not mention an allowed percentage of false-noncompliant screening results but of course the user has every reason to keep this percentage limited. According to the Commission Decision 2002/657/EC, the percentage of false compliant results for screening purposes, applied in conformity with Council Directive $96 / 23 / E C$, has to be less than $5 \%$ ( $\beta$ error). In this article we consider a percentage of $5 \%$ false positive results as reasonable and acceptable.

On the other hand, according to European legislation, milk for human consumption may not contain colostrum since its addition adversely affects the hygienic quality of milk and its technological suitability (Feagan, 1979; Ibrahim et al., 1990; Raynal-Ljutovac et al., 2005). The presence of colostrum in bulk milk due to a bad farming practice can cause interference on the results of microbial test (false positives) because of the differences of composition. However, there are no studies to evaluate the influence of goat colostrum on the response of microbial tests.

Therefore, the aim of this study was to evaluate the use of microbial inhibitor tests for the analysis of goat colostrum on antibiotic residues and the interference caused by the presence of colostrum secretions in goat milk on the response of microbial inhibitors tests. 


\section{Material and methods}

\subsection{Colostrum and milk samples}

Forty-three Murciano-Granadina dairy goats from the experimental flock of the Animal Science and Technology Institute of Universitat Politècnica de València (Valencia, Spain) were used. Animals had good health status and did not receive veterinary treatment before or during the experimental period.

After birth, goat kids were feed by artificial rearing, and the goats were milked every 12 hours ( 8 am and 8 pm) during the first week of lactation using a milking parlour (high line; CASSE $2 \times 12 \times 6$; Alfa Laval ${ }^{\circledR}$, Lund, Sweden). The colostrum and milk samples (300 $\mathrm{ml}$ each) were stored at $4{ }^{\circ} \mathrm{C}$ until their subsequent analysis.

To study the influence of different concentrations of colostrum in goat milk on the microbial inhibitor tests, colostrum was added in different concentrations to antibiotic and colostrum-free tank goat milk. The colostrum samples employed were of four time points namely 12, 24, 36 and 48 hours post-partum. For each time point a colostrum mixture out of eight individual colostrums was prepared; the individual colostrums were previously stored frozen $\left(50 \mathrm{ml}\right.$ at $-40{ }^{\circ} \mathrm{C}$ for maximum 8 weeks). Twelve concentrations of each type of colostrum into antimicrobial and colostrum-free goat milk $(0,1,2.5,5,7.5,10,12.5,15,20$, 25,35 , and $50 \%$ ) were used.

The procedure to determine the physico-chemical parameters, gross composition, somatic cell count (SCC) and content of immunoglobulin $\mathrm{G}$ of experimental samples $(\mathrm{n}=$ $602)$ and mixtures of milk with of colostrum $(n=64)$ have previously been described by Romero et al. (2013).

\subsection{Microbial inhibitor tests}

The microbial methods used were: BRT MRL (AiM Analytik in MilchProduktions-und Vertriebs-GmbH, Munich, Germany), Delvotest SP-NT MCS (DSM Food Specialties, Delft, the Netherlands), and Eclipse 100 (ZEULAB S.L., Zaragoza, Spain). The standard format is a microplate with 96 wells containing the test organism Geobacillus stearothermophilus var. calidolactis and a pH-indicator (bromocresol purple) for Delvotest SP-NT MCS and Eclipse 100 , or a redox-indicator (brilliant black) for BRT MRL. The samples were analysed following the instructions provided by the kit manufacturers. On each microtiter plate a negative and a positive control of benzylpenicillin (PENNA, Sigma-Aldrich Química SA, Madrid, Spain) at a concentration of $4 \mu \mathrm{g} / \mathrm{kg}$ in goat milk were introduced. Microbial tests were incubated at $64 \pm$ $1 \stackrel{\circ}{ } \mathrm{C}$ in a waterbath for about 2.5 to 3 hours, until the colour change of the test medium in the 
cup with the negative control occurred. The Eclipse 100 method required a preliminary prediffusion step at room temperature before incubation.

The interpretation of the test results was carried out visually by three trained technicians assessing the colour change of the test medium; classifying milk samples as "positive" when the colour remained purple/blue, "negative" when the colour changed to yellow, and "doubtful" with colours in between yellow and blue/purple.

Samples of colostrum and milk collected during the first week of lactation were tested in triplicate using the microbial inhibitors tests, while for the milk samples spiked with colostrum 12 replicates of each concentration were assayed.

\subsection{Statistical Analysis}

To evaluate the effect of hours post-partum and physico-chemical parameters, composition, IgG content and SCC on the positive results in the methods for inhibitor detection, a stepwise option of the logistic regression model was used:

$$
L_{i j}=\operatorname{Logit}\left[P_{i j}\right]=\beta_{0}+\beta_{1}[H P P]+\Sigma \beta_{i} \cdot[C]_{i}+\varepsilon_{i j}
$$

Where: Logit $\left[P_{i j}\right]=$ probability for the response, positive; $\beta_{0}=$ the intercept, $\beta_{1}, \beta_{i}=$ estimate parameters for the model; $[H P P]=$ effect of hours post-partum; $[C]_{i}=$ effect of milk components; $(\mathrm{i}=11 ; \mathrm{pH}=\mathrm{pH}$ values; $\mathrm{D}=$ density; $\mathrm{CN}=$ conductivity; $\mathrm{FP}=$ freezing point; $\mathrm{TS}=$ total solids; $F=$ fat; $P=$ protein; $L=$ lactose; $\lg G=$ immunoglobulin $G ; L S C C=\log _{10} S C C$ ); $\varepsilon_{i j}=$ residual error.

To determine the effect of the presence of colostrum on the response of microbial methods for the detection of antibiotics in milk (colostrum interference level) logistic regression analysis was also applied to the model:

$$
L_{i j k}=\operatorname{logit}\left[P_{i j k}\right]=\beta_{0}+\beta_{1}\left[C_{i}\right]+\beta_{2}\left[T C_{j j}\right]+\varepsilon_{i j k}
$$

Where: $\left[P_{\mathrm{ijk}}\right]=$ probability for the response, positive; $\beta_{0}=$ the intercept; $\beta_{1}, \beta_{2}=$ estimate parameters for the model; $\left[C_{i}\right]=$ effect of colostrum concentration $(i=0,1,2.5,5,7.5,10$, $12.5,15,20,25,35$, or $50 \%$ ); [ $\left.\mathrm{TC}_{\mathrm{j}}\right]=$ effect type of colostrum, expressed in dummy variables (colostrum of 12 hours: $Z_{1}=0, Z_{2}=0$, and $Z_{3}=0$; colostrum of 24 hours: $Z_{1}=1, Z_{2}=0$, and $Z_{3}=$ 0 ; colostrum of 36 hours: $Z_{1}=0, Z_{2}=1$, and $Z_{3}=0$, and colostrum of 48 hours: $Z_{1}=0, Z_{2}=0$, and $\left.Z_{3}=1\right) ; \varepsilon_{i \mathrm{ik}}=$ residual error.

Using the logistic model, the inhibitory concentration of colostrum responsible for producing $5 \%\left(\mathrm{IC}_{5}\right)$ positive results ("non-compliant") on the responses of the detection 
methods of inhibitors was determined. Statistical analyses were carried out employing the stepwise option of the logistic regression model of the SAS software (version 9.2, 2008; SAS Institute, Inc., Cary, NC).

\section{Results and discussion}

Table 1 shows the mean of physico-chemical and hygienic parameters of goat colostrum (up to 36 hours post-partum), transition milk (48-96 hours post-partum) and colostrum-free milk (108-168 hours post-partum), these three categories were suggested by Romero et al. (2013) for Murciano-Granadina breed.

Table 1. Physico-chemical and hygienic parameters of goat colostrum, transition milk and colostrum-free milk. $(n=602)$

\begin{tabular}{|c|c|c|c|c|c|c|}
\hline \multirow{2}{*}{ Parameter } & \multicolumn{2}{|c|}{$\begin{array}{c}\text { Colostrum } \\
(0-36 \mathrm{~h})\end{array}$} & \multicolumn{2}{|c|}{$\begin{array}{l}\text { Transition mik } \\
\quad(48-96 h)\end{array}$} & \multicolumn{2}{|c|}{$\begin{array}{c}\text { Milk } \\
(108-168 \text { h) }\end{array}$} \\
\hline & Average & $S^{1}$ & Average & $S^{1}$ & Average & $S^{1}$ \\
\hline $\mathrm{pH}$ & 6.52 & 0.09 & 6.59 & 0.02 & 6.67 & 0.03 \\
\hline Conductivity $(\mathrm{mS} / \mathrm{cm})$ & 4.85 & 0.16 & 5.04 & 0.12 & 5.03 & 0.06 \\
\hline Density $(\mathrm{g} / \mathrm{L})$ & 1,041 & 0.006 & 1,033 & 0.001 & 1,030 & 0.001 \\
\hline Freezing Point $\left(-\mathrm{m}^{\circ} \mathrm{C}\right)$ & 553 & 31 & 554 & 6 & 552 & 3 \\
\hline Dry Matter (\%) & 22.54 & 4.84 & 17.75 & 0.45 & 17.10 & 0.42 \\
\hline Fat $(\%)$ & 8.31 & 1.14 & 7.08 & 0.17 & 6.97 & 0.35 \\
\hline Protein (\%) & 8.37 & 3.66 & 5.05 & 0.32 & 4.42 & 0.19 \\
\hline $\lg G^{2}(\mathrm{mg} / \mathrm{ml})$ & 11.63 & 12.53 & 1.42 & 0.49 & 0.72 & 0.04 \\
\hline Lactose (\%) & 3.75 & 0.65 & 4.59 & 0.09 & 4.78 & 0.03 \\
\hline $\operatorname{LSCC}^{3}$ & 6.00 & 0.06 & 5.68 & 0.11 & 5.58 & 0.04 \\
\hline
\end{tabular}

${ }^{1}$ SD: Standard deviation; ${ }^{2} \operatorname{lgG}$ : Immunoglobulin G; ${ }^{3}$ LSCC: Log $_{10}$ Somatic Cell Count

For most compounds studied colostrum showed the highest mean values, which a decrease as the lactation period advanced, except for the parameters $\mathrm{pH}$, conductivity and lactose. 
Table 2 shows the results and the specificity for the microbial inhibitor tests obtained during the first week of lactation. All microbial tests presented a high number of noncompliants results (positive and doubtful) up to 24 hours post-partum. From that moment onwards, the Delvotest SP-NT MCS and Eclipse 100 presented a significant increase in specifity, with the Delvotest SP-NT MCS reaching specificity above 95\% at 36 hours postpartum, while the BRT MRL and Eclipse 100 did only reach the rate of non-compliant results below $5 \%$ from 96 hours post-partum.

Moreover, it should be noted that in the colostrum analysis until 48 hours post-partum, atypical colourations of the doubtful results (BRT MRL: brown and grey; Delvotest SP-NT MCS and Eclipse 100: green and blue) with microbial tests are often observed; besides, a dull film on top of the wells, likely due to the high concentration of colostrum components (fat, protein, etc), was also observed, which may imply a poor diffusion of the samples in the agar and a difficult interpretation of the results.

The results obtained in this study show that none of the microbial tests studied was suitable for the analysis of antibiotic residues in colostrum (secretions 0-36 hours postpartum; Romero et al., 2013) at all time points, as they presented high rates of noncompliant (positive) results. Only the Delvotest SP-NT MCS could be used for the analysis of transition milk (secretions between 48-96 hours post-partum; Romero et al., 2013) at all time points.

Egan et al. (1984) analysed bovine colostrum of the first milking by disc assays with different test microorganisms (Bacillus stearothermophilus var. calidolactis, Bacillus subtilis and Streptocococcus thermophilus), obtaining for Geobacillus stearothermophilus var. calidolactis a specificity of $76.3 \%$, being much higher than observed in this study (14.027.9\%). Furthermore, Andrew (2001) analysed bovine colostrum and transition milk using the Delvotest SP, and also obtained for colostrum a high specificity of $88 \%$. However, for transition milk it was $92 \%$, slightly lower than the results observed in this study. 
Table 2. Specificity of microbial tests during the first week of lactation

\begin{tabular}{|c|c|c|c|c|c|c|c|c|c|c|c|c|}
\hline \multirow{2}{*}{ HPP $^{1}$} & \multicolumn{4}{|c|}{ BRT MRL } & \multicolumn{4}{|c|}{ Delvotest SP-NT MCS } & \multicolumn{4}{|c|}{ Eclipse 100} \\
\hline & $\mathbf{N}^{2}$ & $D^{3}$ & $\mathbf{P}^{4}$ & $\mathrm{~S} \%^{5}$ & $\mathbf{N}^{2}$ & $D^{3}$ & $\mathbf{P}^{4}$ & $\mathrm{~S} \%^{5}$ & $\mathbf{N}^{2}$ & $D^{3}$ & $\mathbf{P}^{4}$ & $\mathrm{~S} \%^{5}$ \\
\hline $0-12$ & 10 & 20 & 13 & 23.3 & 12 & 21 & 10 & 27.9 & 6 & 22 & 15 & 14.0 \\
\hline 24 & 23 & 15 & 5 & 53.5 & 30 & 8 & 5 & 69.8 & 14 & 17 & 12 & 14.0 \\
\hline 36 & 27 & 5 & 11 & 62.8 & 42 & 1 & 0 & 97.7 & 31 & 8 & 4 & 72.1 \\
\hline 48 & 36 & 3 & 4 & 83.7 & 42 & 1 & 0 & 97.7 & 37 & 4 & 2 & 86.0 \\
\hline 60 & 40 & 1 & 2 & 93.0 & 43 & 0 & 0 & 100 & 39 & 3 & 1 & 90.7 \\
\hline 72 & 40 & 0 & 3 & 93.0 & 43 & 0 & 0 & 100 & 40 & 3 & 0 & 93.0 \\
\hline 84 & 39 & 4 & 0 & 90.7 & 43 & 0 & 0 & 100 & 38 & 2 & 3 & 88.4 \\
\hline 96 & 42 & 1 & 0 & 97.7 & 43 & 0 & 0 & 100 & 41 & 1 & 1 & 95.3 \\
\hline 108 & 42 & 1 & 0 & 97.7 & 43 & 0 & 0 & 100 & 41 & 2 & 0 & 95.3 \\
\hline 120 & 42 & 1 & 0 & 97.7 & 43 & 0 & 0 & 100 & 41 & 2 & 0 & 95.3 \\
\hline 132 & 42 & 1 & 0 & 97.7 & 43 & 0 & 0 & 100 & 42 & 1 & 0 & 97.7 \\
\hline 144 & 42 & 1 & 0 & 97.7 & 43 & 0 & 0 & 100 & 43 & 0 & 0 & 100 \\
\hline 156 & 43 & 0 & 0 & 100 & 43 & 0 & 0 & 100 & 43 & 0 & 0 & 100 \\
\hline 168 & 43 & 0 & 0 & 100 & 43 & 0 & 0 & 100 & 43 & 0 & 0 & 100 \\
\hline
\end{tabular}

${ }^{1}$ HPP: Hours post-partum; ${ }^{2} \mathrm{~N}$ : Negative results; ${ }^{3} \mathrm{D}$ : Doubtful results; ${ }^{4} \mathrm{P}$ : Positive results; ${ }^{5} \mathrm{~S} \%$ : Specificity (negatives/total x 100 ) 
As microbial inhibitor tests are economical and easy to use, they are frequently employed for the analysis of antibiotics, although they are not suitable for the analysis of colostral secretions. Should these tests nevertheless be used to analyse colostrum, some kind of methodological adaptation would be necessary such as the use of buffers to facilitate the diffusion of this type of matrix in the agar or to neutralize the possible natural inhibitors present.

Statistical analysis of the results by logistic regression analysis showed a significant effect of some parameters on the response of microbial tests. Table 3 shows that a higher protein concentration increases the probability to obtain a positive result in all microbial tests. It should be taken into account that goat colostrum is characterised by a high protein content compared to goat milk (Argüello et al., 2006; Romero et al., 2013).

Table 3. Logistic model to predict the non-compliant results on microbial tests in goat mammary secretions during the first week of lactation

Microbial Test $\quad L=$ Logit $[P]=\beta_{0}+\beta_{1}[H P P]+\Sigma \beta_{i} \cdot[C]_{i} \quad \% C$

BRT MRL

$$
L=-2.9281-0.0239[H P P]+0.2981[P]
$$

Delvotest SP-NT MCS

$$
L=-45.4839+5.5019[P]-0.9453[\mathrm{pH}]
$$

Eclipse 100

$$
L=-3.9218-0.0271[H P P]+0.5440[P]
$$

Logit $[P]=$ probability for the response, positive or negative; $\beta_{0}, \beta_{1}$ and $\beta_{i}=$ estimate parameters for the model; $[\mathrm{HPP}]=$ hours post-partum, $[\mathrm{C}]_{i}=$ componets of milk estudied; \%C: percentage of concordance

Also, colostrum is containing high concentrations of proteins such as immunoglobulins, lactoferrin, lysozymes, etc (Hiss et al., 2008; Sánchez-Macías et al., 2014). Some authors have suggested that these components have an inhibitory effect on the growth of Geobacillus stearothermophilus var. calidolactis, the microorganism frequently used in microbial inhibitor tests (Carlsson et al., 1989; Pan et al., 2007).

The effect of hours post-partum was significant on the response of the BRT MRL and Eclipse100, i.e. positive or "non-compliant" results gradually decreased as lactation progressed. However, post-partum hours were not significant in the Delvotest SP-NT MCS, since at 36 hours the test did not show positive results, showing a high specificity. 
In the case of the Delvotest SP-NT MCS, also the $\mathrm{pH}$ had a significant effect on the response, showing a higher frequency of positive results at lower $\mathrm{pH}$ values. The high acidity is characteristic for colostrum, just as its protein content, especially during the first hours post-partum (Romero et al., 2013), when the largest number of doubtful and positive results appears in this method.

Although all microbial inhibitor tests employ the same test organism (Geobacillus stearothermophilus var. calidolactis), the indicator systems used are different (brilliant black by the BRT MRL and bromocresol purple by the Delvotest SP-NT MCS and Eclipse 100). Furthermore, the Eclipse 100, contrary to the other two methods, uses a prediffusion of the samples for one hour at room temperature followed by a washing step with distilled water before incubation. The tests also show differences in detection capabilities. These analytical variations could explain the different results found with each test.

From a practical viewpoint, it is interesting to know if the presence of colostrum in milk due to a bad farming practice concerning animal identification and separation of colostral secretions, could cause non-compliant results in routine quality control of inhibitors. For this purpose the effect of different concentrations of colostrum in goat milk on the responses of microbial inhibitor tests was studied. The raw milk used provided physico-chemical and hygienic parameters $(\mathrm{pH}$ value: $6.80 \pm 0.80$; fat: $5.50 \pm 1.09 \%$, protein: $3.30 \pm 0.86 \%$, dry matter: $14.40 \pm 1.29 \%$, lgG: $0.010 \pm 0.008 \mathrm{mg} / \mathrm{ml}$ and SCC: $685 \pm 385 \times 10^{3} \mathrm{cell} \cdot \mathrm{ml}^{-1}$ ) similar to those reported by other authors for goat milk (Salama et al., 2003; Park et al., 2007).

Table 4 shows that the presence of colostrum obtained at 12 and 24 hours in goat milk affected the response of all microbial tests. Positive results for the BRT MRL were caused by relatively low concentrations (7.5-10\%) of colostrum, while for the Delvotest SP-NT MCS and Eclipse 100 only high concentrations of colostrum ( $\geq 35 \%$ ) caused non-compliant results. Moreover, the addition of colostrum of 36 to 48 hours only affected the BRT MRL at concentrations $\geq 20 \%$, indicating a higher sensitivity to the presence of colostral secretions in milk than other tests studied herein.

The prediction equations of positive results depending on the concentration and age of colostrum are presented in Table 5. The concentration of colostrum affects the response of all microbial tests studied, presenting more positive results at a high concentration. On the other hand, the addition of colostrum of differents hours post-partum only affected the response of the BRT MRL and Eclipse 100, displaying a greater inhibitory effect in colostrum obtained shortly after partum. From these equations the inhibitory concentrations of colostrum responsible for producing $5 \%$ positive results $\left(\mathrm{IC}_{5}\right)$ were calculated for each of the 
methods studied. In BRT MRL, it can be observed that as time passes from partum higher concentrations of colostrum are needed to influence the response of the tests; it was the test that showed a lower $\mathrm{IC}_{5}$ for all types of colostrum.

Table 4. Frequency of positive results of microbial methods according to the concentration and type of colostrum added to goat milk

\begin{tabular}{|c|c|c|c|c|c|c|c|c|c|c|}
\hline \multirow{2}{*}{ Microbial Test } & \multirow{2}{*}{$\mathrm{TC}^{1}$} & \multicolumn{9}{|c|}{ Colostrum Concentration (\%) } \\
\hline & & $0-5$ & 7.5 & 10 & 12.5 & 15 & 20 & 25 & 35 & 50 \\
\hline \multirow{4}{*}{ BRT MRL } & $0-12$ & 0 & 12.5 & 25 & 43.7 & 75 & 100 & 100 & 100 & 100 \\
\hline & 24 & 0 & 0 & 18.7 & 31.2 & 62.5 & 100 & 100 & 100 & 100 \\
\hline & 36 & 0 & 0 & 0 & 0 & 0 & 12.5 & 25 & 50 & 100 \\
\hline & 48 & 0 & 0 & 0 & 0 & 0 & 12.2 & 18.7 & 31.2 & 50 \\
\hline \multirow{3}{*}{$\begin{array}{c}\text { Delvotest } \\
\text { SP-NT MCS }\end{array}$} & $0-12$ & 0 & 0 & 0 & 0 & 0 & 0 & 0 & 50 & 100 \\
\hline & & & & & & & & & & \\
\hline & 24 & 0 & 0 & 0 & 0 & 0 & 0 & 0 & 50 & 100 \\
\hline \multirow{2}{*}{ Eclipse 100} & 0-12 & 0 & 0 & 0 & 0 & 0 & 0 & 0 & 100 & 100 \\
\hline & 24 & 0 & 0 & 0 & 0 & 0 & 0 & 0 & 6.2 & 100 \\
\hline
\end{tabular}

${ }^{1} \mathrm{TC}$ : Type of colostrum obtained at different hours post-partum

The inhibitor concentration of colostrum in goat milk which produced false positive results on microbial tests was lower for BRT MRL (5.1-19.5\%) than for Delvotest SP-NT MCS (32.6\%) and Eclipse 100 (25.1-34.2\%). In caprine livestock the milk containing colostrum may occur more frequently if reproduction management is performed in groups, since a large number of animals would be in the same stage of lactation. If the groups are not correctly identified and separated, a considerable mixture of colostrum with goat milk may occur and could cause false non-compliant results in microbial screening tests, which would suppose an economic problem for farmers and dairy industry. 
Table 5. Effect of the different concentrations and type of colostrum added to goat bulk milk on the response of microbial tests

\begin{tabular}{|c|c|c|c|c|c|c|}
\hline \multirow{2}{*}{$\begin{array}{l}\text { Microbial } \\
\text { Test }\end{array}$} & \multirow{2}{*}{$L=$ Logit $[P]=\beta_{0}+\beta_{1}[C]+\beta_{2}[T C]$} & \multirow{2}{*}{$\% \mathrm{C}$} & \multicolumn{4}{|c|}{$\mathrm{IC}_{5} \%$} \\
\hline & & & $12 \mathrm{~h}$ & $24 \mathrm{~h}$ & $36 \mathrm{~h}$ & $48 \mathrm{~h}$ \\
\hline BRT MRL & $\begin{array}{c}\mathrm{L}=-3.9281+0.189[\mathrm{C}]-0.8938\left[\mathrm{Z}_{1}\right]- \\
1.9442\left[\mathrm{Z}_{2}\right]-2.6891\left[\mathrm{Z}_{3}\right]\end{array}$ & 94 & 5.2 & 9.9 & 15.5 & 19.5 \\
\hline $\begin{array}{l}\text { Delvotest } \\
\text { SP-NT MCS }\end{array}$ & $L=-42.4525+1.2129[C]$ & 98.4 & 32.6 & 32.6 & - & - \\
\hline Eclipse 100 & $L=-9.1468+0.2488[C]-2.2314\left[Z_{1}\right]$ & 93.8 & 25.1 & 34.2 & - & - \\
\hline
\end{tabular}

Logit $[P]=$ probability for the response, positive or negative; $\beta_{0}=$ the intercept; $\beta_{1}, \beta_{2}=$ estimate parameters for the model; $\left[C_{i}\right]=$ effect of colostrum concentration $(i=0,1,2.5,5,7.5,10,12.5,15,20$, 25, 35 and 50\%); $\left[\mathrm{TC}_{\mathrm{j}}\right]=$ effect type colostrum, expressed in Dummy variables (colostrum 12 hours post-partum: $Z_{1}=0, Z_{2}=0$, and $Z_{3}=0$; colostrum 24 hours post-partum: $Z_{1}=1, Z_{2}=0$, and $Z_{3}=0$; colostrum 36 hours post-partum: $Z_{1}=0, Z_{2}=1$, and $Z_{3}=0$, and colostrum 48 hours post-partum: $Z_{1}=0$, $Z_{2}=0$, and $\left.Z_{3}=1\right) ; \% C=$ percentage of concordance; $I C_{5} \%=$ inhibitory concentration of colostrum

\section{Conclusions}

Microbial tests for the detection of inhibitors in milk are not suitable for monitoring the presence of antibiotic residues in goat colostrum as a high percentage of "false positives" in testing of secretions until 24 hours post-partum is obtained. Moreover, the occurrence of positive or "non-compliant" results is mainly related to the effect of post-partum hours and the high protein content of colostrum. The presence of goat colostrum to raw milk affects more the response of the BRT MRL than Delvotest SP-NT MCS and Eclipse 100, especially with colostrum obtained shortly after partum (12 and 24 hours). Therefore, to avoid the interference caused by the presence of colostrum in milk, it is recommended to adhere to good farming practices concerning animal identification and separation of colostral secretions, especially during the first 48 hours after delivery. In this way colostrum is prevented to get mixed with the milk which can cause "non-compliant" results in microbial tests for the detection of inhibitors.

\section{Acknowledgements}

This work is part of the AGL-2009-11524 funded by the Ministry of Science and Innovation (Madrid, Spain) and the Generalitat Valenciana (ACOMOP/2012/164, Valencia, Spain). The authors are grateful to AiM Analytik in MilchProduktions-und Vertriebs-GmbH 
(Munich, Germany), DSM Food Specialties (Delft, the Netherlands) and ZEULAB S.L. (Zaragoza, Spain) for their support.

\section{References}

Andrew, S.M. 2001. Effect of composition of colostrum and transition milk from Holstein heifers on specificity rates of antibiotic residue tests. J. Dairy Sci. 84: 100-106.

Anonymous. 1908. Rapport technique de clôture de Eugène Roux in Société Universelle de la Croix-Blanche de Genève, Compte rendu des travaux du 1er Congrès International pour la Répression des Fraudes alimentaires et pharmaceutiques, Genève 8-12 septembre 1908, Genève, imp. I. Soullier.

Argüello, A., Castro N., Capote J. 2004. Growth of milk replacer kids fed under three different managements. J. Appl. Anim. Res. 25: 37-40.

Argüello, A., Castro, N., Álvarez, S., Capote C. 2006. Effects of the number of lactations and litter size on chemical composition and physical characteristics of goat colostrum. Small Rumin. Res. 64: 53-59.

Beltrán, M.C., Berruga, M.I., Molina, A., Althaus, R.L., Molina M.P. 2015. Performance of the current microbial tests for screening antibiotic in sheep and goat milk. Int. Dairy J. 41: 1315.

Berruga, M.I., Beltrán, M.C., Novés, B., Molina, A., Molina, M.P. 2011. Effect of penicillins on the acidification of yogurt made from ewe's milk during the storage. pp. 145-149. A. Mendez-Vilas. (Eds.). Science and Technology Against Microbial Pathogens. Research, Development and Evaluation, World Scientific Publishing, Hackensack, N.J.

Carlsson, A., Björck, L., Persson, K. 1989. Lactoferrin and lysozyme in milk during acute mastitis and their inhibitory effect in Delvotest P. J. Dairy Sci. 72: 3166-3175.

Clare, D.A., Catignani, G.L., Swaisgood, H.E. 2003. Biodefense properties of milk: the role of antimicrobial proteins and peptides. Curr. Pharm. Design. 9: 1239-1255.

Commission Decision 2002/657/EC of 12 August 2002 implementing Council Directive $96 / 23 / E C$ concerning the performance of analitycal methods and the interpretation of results. Off. J. Eur. Union 2002 L221: 8-36.

Commission Regulation (EC) No 1662/2006 of 6 November 2006 amending Regulation (EC) № 853/2004 of the European Parliament and of the Council laying down specific hygiene rules for food of animal origin. Off. J. Eur. Union 2006 L320: 1-10. 
Commission Regulation (EU) No 37/2010 of 22 December 2009 on pharmacologically active substances and their classification regarding maximum residue limits in foodstuffs of animal origin. Off. J. Eur. Union 2009 L15: 1-72.

Comunian, R., Paba, A., Dupre, I., Daga, E.S., Scintu, M.F. 2010. Evaluation of a microbiological indicator test for antibiotic detection in ewe and goat milk. J. Dairy Sci. 93: 5644-5650.

Council Directive 96/23/EC of 29 April 1996 on measures to monitor certain substances and residues there of in live animals and animal products and repealing Directives 85/358/ECC and 86/469/ECC and Decisions 89/187/ECC and 91/664/ECC.Off. J. Eur. Union 1996 L125: 10-32.

Decree 2484/1967 of 21 September 1967, approving the text of the Spanish Food Code. (Art.3.15.01) pp. 142180. Boletín Oficial del Estado (BOE) No 250 of 19 October 1967.

Demoly, P., Romano, A. 2005. Update on beta-lactam allergy diagnosis. Curr. Allergy Asthm. R. 5: 9-14.

Egan, J., Meaney, W.J. 1984. The inhibitory effect of mastitic milk and colostrums on test methods used for antibiotic detection. Ir. J. Food Sci. 8: 115-120.

Feagan, J.T. 1979. Factors affecting protein composition of milk and their significance to dairy processing. Aus. J. Dairy Technol. 60: 167-177.

Fox, L.K., Hancock, D.D., Horner, S.D. 1992. Selective intramamary antibiotic therapy during the nonlactating period in goats. Small Rumin. Res. 9: 313-318.

Ham, J.S., Jeong, S.G., Shin, J.H., Han, G.S., Chae, H.S., Yoo, Y.M., Ahn, J.N., Hur, T.Y., Ko, S.H., Park, K.W., Choi, S.H., Lee, W.K. 2008. Comparison of antimicrobial residue detection in goat milk by Delvo, Eclipse 100, and Parallux Tests. Korean J. Food Sci. An. 28: 59-62.

Hiss, S., Meyer, T., Sauerwein, H. 2008. Lactoferrin concentrations in goat milk throughout lactation. Small Rumin. Res. 80: 87-90.

Ibrahim, E.M., Mohran, M.A., El-Hoda Hanafy, N. 1990. Physicochemical characteristics of colostrum and the influence of its addition in some technological propierties of normal milk. Assiut J. Agri. Sci. 21: 221-239.

IDF. 2010. Current situation \& compilation of commercially available screening methods for the detection of inhibitors /antibiotics residues in milk, FIL-IDF Standard No 442. International Dairy Federation, Brussels, Belgium. 
Keskin, M., Güler, Z., Gül, S., Biçer, O. 2007. Changes in gross chemical composition of ewe and goat colostrum during ten days postpartum. J. Appl. Res. 32: 25-28.

Levieux, D., Morgan, F., Geneix, N., Masle, I., Bouvier, F. 2002. Caprine immunoglobulin G, $\beta$-lactoglobulin, $\alpha$-lactalbumin and serum albumin in colostrum and milk during the early post partum period. J. Dairy Res. 69: 391-399.

Lohuis, J.A.C.M., Poutrel, B., de Cremoux, R., Parez, V., Aguer, D. 1995. Milk residues of penicillin, nafcillin and dihydrostreptomycin in dairy goats postpartum treated with nafpenzal N8[R] at drying-off. pp. 102-103. In: Session 5: treatment of mastitis. Proceedings of the 3rd International Mastitis Seminar. (Ed.). A. Saran and S. Soback, May 28-1 June, Tel Aviv, Israel.

McDougall, S., Annis, F. 2005. Efficacy of antibiotic treatment at drying-off in curing existing infections and preventing new infections in dairy goats. pp. 523-528. In: Hogeveen, $\mathrm{H}$. (Ed.). Mastitis in Dairy Production. Wageningen Academic Press Publishers, the Netherlands.

Molina, M.P., Althaus, R.L., Balasch, S., Torres, A., Peris, C., Fernandez, N. 2003. Evaluation of screening test for detection of antimicrobial residues in ewe milk. J. Dairy Sci. 86: 1947-1952.

Moreno-Indias, I., Sánchez-Macías, D., Castro, N., Morales-delaNuez, A., HernándezCastellano L.E, Capote, J., Argüello, A. 2012. Chemical composition and immune status of dairy goat colostrum fractions during the first $10 \mathrm{~h}$ after partum. Small Rumin. Res. 103: $220-224$.

Nowak, R., Poidron, P. 2006. From birth to colostrum: early steps leading to lamb survival. Reprod. Nutr. Dev. 46: 431-446.

Packham, W., Broome, M.C., Limsowtin, G.K.Y., Roginski, H. 2001. Limitations of standard antibiotic screening assays when applied to milk for cheesemaking. Aust. J. Dairy Technol. 56: 15-18.

Pan, Y., Rowney, M., Guo, P., Hobman, P. 2007. Biological propierties of lactoferrin: an overview. Aus. J. Dairy Assoc. 39: 97-101.

Park, Y.W., Juárez, M., Ramos, M., Haenlein, G.F.W. 2007. Physico-chemical characteristics of goat and sheep milk. Small Rumin. Res. 68: 88-113. 
Raynal-Ljutovac, K., Gaborit, P., Lauret A. 2005. The relationship between quality criteria of goat milk, its technological properties and the quality of the final products. Small Rumin. Res. 60: 167-177.

Regulation (EC) No 853/2004 of the European Parliament and of the Council of 29 April 2004 laying down specific hygiene rules for on the hygiene of foodstuffs. Off. J. Eur. Union 2004 L139: 55-205.

Romero, T., Beltrán, M.C., Rodríguez, M., Martí De Olives, A., Molina, M.P. 2013. Short communication: Goat colostrum quality: Litter size and lactation number effects. J. Dairy Sci. 96: 7526-7531.

Salama, A.A.K., Such, X., Caja, G., Rovai, M., Casals, E., Albanell, M.P., Martí, A. 2003. Effects of once versus twice daily milking thought lactation on milk yiled and milk composition in dairy goats. J. Dairy Sci. 86: 1673-1680.

Sánchez-Macías, D., Moreno-Indias, I., Castro, N., Morales-delaNuez, A., Argüello, A. 2014. From goat colostrum to milk: Physical, chemical, and immune evolution from partum to 90 days postpartum. J. Dairy Sci. 97: 10-16.

Sanders, P., Bousquet-Melou, A., Chauvin, C., Toutain, P.L. 2011. Utilisation des antibiotiques en élevage et en jeux de santé publique (Use of antibiotics in animal and public health issues). INRA Prod. Anim. 24: 199-204.

Zeng, S.S., Escobar, E.N., Brown-Crowder, I. 1996. Evaluation of screening tests for detection of antibiotics in goat milk. Small Rumin. Res. 21: 155-160. 


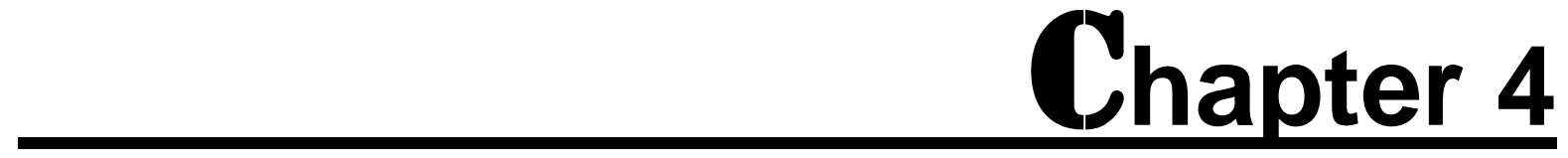

The occurrence of positive results in microbial inhibitor tests due to the presence of detergents and disinfectants in goat milk 



\title{
Detection of antibiotics in goat milk: effect of detergents on the response of microbial inhibitor tests
}

\begin{abstract}
The aim of the study was to evaluate the interference of acid and alkaline detergents employed in the cleaning of milking equipment of caprine dairy farms on the performance of microbial tests used in antibiotic control (BRT MRL, Delvotest SP-NT MCS, and Eclipse 100). Eight concentrations of commercial detergents, five acid $(0-0.25 \%)$ and five alkaline $(0-1 \%)$ were added to antimicrobial-free goat milk to evaluate the detergent effect on the response of microbial inhibitor tests. To evaluate the effect of detergents on the detection capability of microbial tests two detergents at $0.5 \mathrm{ml} / \mathrm{l}$ (one acid and one basic) and eight concentrations of four beta-lactam antibiotics (ampicillin, amoxicillin, cloxacillin, and benzylpenicillin) were used. Milk without detergents was used as control. The spiked samples were analysed twelve times by three microbial tests. The results showed that the presence of acid detergents did not affect the response of microbial tests for any of the concentrations tested. However, at concentrations equal to or greater than $2 \mathrm{ml} / \mathrm{l}$ alkaline detergents positive results were found in microbial tests (16.7-100\%). The detection limits of the screening tests for penicillins were not modified substantially by the presence of detergents. In general, the presence of acid and alkaline detergents in goat milk did not produce a great interference in the microbial tests, only high concentrations of detergents could cause non-compliant results, but these concentrations are difficult to find in practice in milk if proper cleaning procedures are applied in caprine dairy farms.
\end{abstract}

Keywords: Detergents, inhibitors, screening methods, goat milk. 


\section{Introduction}

Veterinary drug residues in milk are a growing concern among consumers, because of the risk they might pose for health, i.e. generating allergies, toxic reactions antibiotic resistence (Alanis, 2005; Demoly and Romano, 2005; Sanders et al., 2011), and technological implications in the manufacture of dairy products (Packham et al., 2001; Adetunji, 2011). Therefore, Maximum Residue Limits (MRLs) of drugs in different foodstuffs of animal origin, including milk, have been defined by Regulation (EC) No 470/2009 and established by Commission Regulation (EU) No 37/2010).

Currently, there are numerous screening tests commercially available to detect antimicrobial residues in milk (IDF, 2010). In control laboratories, microbial inhibitor tests are widely used thanks to their simplicity, low cost and wide range of detection. Microbial inhibitor tests are based on the inhibition of spore outgrowth of the test microorganism, the most commonly applied being Geobacillus stearothermophilus var. calidolactis; a thermophilic bacterium highly sensitive to beta-lactam antibiotics. Screening microbial tests are nonspecific methods and may be affected by different substances capable of inhibiting test microorganism growth, causing positive results in antibiotic-free milk samples, such as natural inhibitors (Andrew, 2001), and preservatives (Molina et al., 2003), among others. Detergents and disinfectants used in the cleaning of milking parlours and milk tanks are a possible source of residues in milk and have occasionally been associated with the positive results obtained in microbial tests (Fabre et al., 1995).

The hygienic production of milk implies the use of cleaning products to prevent the proliferation of microorganisms on surfaces that come into direct contact with milk, such as milking machines and milk storage tanks (Pontefract, 1991). Following good cleaning practices, the residues of detergents in milk should be minimal (<2 ppm; Reybroeck, 1997), although owing to errors in the washing temperature, dosage, and inadequate post-rinse the concentration of these cleaning products can be higher, which may alter the organoleptic characteristics of milk (Dunsmore et al., 1985; Merin et al., 1985) and interfere in the activity of startercultures used by the dairy industry (Guirguis and Hickey, 1987; Petrova and Dimitrov, 1993).

Moreover, only few studies using cow milk have evaluated the effect of detergents on the presence of positive results in microbial inhibitor tests, showing controversial results. Some authors (Zvirdauskiene and Salomskiene, 2007; Salomskiene et al., 2013) only found false positive results at very high concentrations of alkaline detergents, equal or superior to the dose recommended by the manufacturers. However, Schiffmann et al. (1992) obtained 
non-compliant results at lower concentrations (0.01\%), whereas Merin et al. (1985) for these concentrations did not obtain any positive results, although they employed a limited number of cleaning products and microbial methods. Furthermore, these studies focus on positive outcomes; there is no information about the effect of detergents on the detection capability of microbial methods.

Therefore, the goal of this study was to analyse the effect of detergents used in the cleaning of milking equipment on the performance of microbial tests for screening antibiotics in goat milk.

\section{Material and methods}

\subsection{Microbial inhibitor tests}

The microbial inhibitor tests were: Brilliant Black Reduction Test MRL (BRT MRL) (AiM, Analytik in MilchProduktions- und Vertriebs-GmbH, Munich, Germany), Delvotest SP-NT MCS (DSM Food Specialties, Delft, the Netherlands) and Eclipse 100 (ZEULAB-, Zaragoza, Spain). The tests were used according to each manufacturer's instructions. A negative control (antimicrobial-free milk) and a positive control (antimicrobial-free milk spiked with 4 $\mu \mathrm{g} / \mathrm{kg}$ of benzylpenicillin) were included in each test. Visual interpretation of the test results was carried out independently by three trained technicians and the results were evaluated as 'negative' (yellow) or 'positive' (blue or purple).

\subsection{Goat milk samples}

Antimicrobial-free milk samples to be used as 'negative milk' were obtained according to the requirements established by the IDF (ISO13969/IDF183:2003). Therefore, mixed milk of 10 Murciano-Granadina goats in mid-lactation (more than $90 \mathrm{~d}$ and below $150 \mathrm{~d}$ postpartum) from the experimental flock of Universitat Politècnica de València (Valencia, Spain) was used. Animals had a good health status and did not receive any veterinary drugs before or during the experimental period. Moreover, goats were fed diets formulated and produced in the experimental feed processing plant of Universitat Politècnica de València using first-class raw materials without added antibiotics. All milk samples were analysed to check the physicochemical and hygienic quality parameters using MilkoScan 6000 (Foss, Hillerød, Denmark) to determine gross composition (fat, protein and total solids); somatic cell count (SCC) was obtained employing Fossomatic 5000 (Foss); bacterial count (BC) was determined using Bactoscan FC (Foss) and the $\mathrm{pH}$ value was measured by a conventional pHmeter (Crison, Barcelona, Spain). 


\subsection{Spiked milk samples: detergents and antibiotics}

The detergents used for the study of their presence on the microbial test response were commercial detergents of the acid and alkaline type, which were added to the antibiotic-free goat milk at concentrations of: $0,0.25,0.5,0.75,1,1.5,2,2.5 \mathrm{ml} / \mathrm{l}$ for acid and 0, 0.5, 1, 2, 4, $6,8,10 \mathrm{ml} / \mathrm{l}$ for alkaline (Table 1). Concentrations tested for acid detergents were lower than those selected for the alkaline detergents, as higher concentrations produce milk coagulation. Each concentration was tested twelve times by microbial methods (BRT MRL, Delvotest SP-NT MCS, and Eclipse 100).

Table 1. Brand name, composition and recommended dose of acid and alkaline detergents

\begin{tabular}{|c|c|c|c|}
\hline Detergent & Brand Name & Composition (\%) & $\begin{array}{c}\text { Recommended } \\
\text { dose (\%) }\end{array}$ \\
\hline \multirow{5}{*}{ Acid } & $\mathrm{Cid}^{1}$ & phosphoric acid/sulphuric acid (15-30/5-15\%) & $0.5-1$ \\
\hline & 105 Nifos $^{3}$ & phosphoric acid/sulphuric acid (25/5 \%) & $0.5-1$ \\
\hline & Grupacid $^{4}$ & phosphoric acid/sulphuric acid (25/5\%) & $0.5-2$ \\
\hline & Manocid $^{5}$ & ortophosphoric acid/nitric acid (25/10 \%) & $0.5-1$ \\
\hline & Circoaction $\mathrm{SF}^{2}$ & phosphoric acid/sulphuric acid (20-30/5-10\%) & $0.5-1$ \\
\hline \multirow{5}{*}{ Alkaline } & Basix $^{1}$ & sodium hydroxide/sodium hypochlorite (5-15/5-15\%) & $0.5-1$ \\
\hline & Circoaction $\mathrm{AF}^{2}$ & sodium hydroxide/sodium hypochlorite (<20/<10\%) & $0.5-1$ \\
\hline & Clor $\mathrm{FW}^{3}$ & sodium hydroxide/sodium hypochlorite (5/5\%) & $0.5-1$ \\
\hline & Grupaclor ${ }^{4}$ & sodium hydroxide/sodium hypochlorite (5/10 \%) & $0.5-1$ \\
\hline & Manobactyl $^{5}$ & sodium hydroxide/sodium hypochlorite (5-10/5-10 \%) & $0.5-1$ \\
\hline
\end{tabular}

${ }^{1}$ DeLaval International A.B., (Tumba, Sweden)

${ }^{2}$ GEA Farm Technologies Ibérica, S.L., (Barcelona, Spain)

${ }^{3}$ OXA Chemical Specialties, CYGYC S.A., (Barcelona, Spain)

${ }^{4}$ Grupanor-Cercampo S.A., (Madrid, Spain)

${ }^{5}$ Manovac S.L., (Valencia, Spain)

To evaluate the effect of detergents on the detection capability of microbial screening methods for penicillins, the detection limits (DLs) for ampicillin, amoxicillin, cloxacillin and benzylpenicillin were calculated according to ISO13969/ IDF183:2003 specifications. To do so, two detergents were chosen, an acid one (Circoaction SF, Westfalia Surge Ibérica SL, Spain) and a basic one (Circoaction AF, Westfalia Surge, Ibérica SL, Spain), which were 
then added to antibiotic-free goat milk at the maximum detergent concentration, not showing interferences in the response of the microbial tests, nor significantly altering the $\mathrm{pH}$ of milk $(0.5 \mathrm{ml} / \mathrm{l})$. Furthermore, goat milk samples without detergents were used as control.

The goat milk samples, with or without detergents, were spiked with eight different antibiotic concentrations (Table 2), prepared following the recommendations of the IDF (2003). The antibiotics selected for this study were supplied by Sigma-Aldrich (Madrid, Spain): amoxicillin (31586), ampicillin (A-9518), cloxacillin (C-9393), and benzylpenicillin (PENNA). All the antibiotic standard solutions were prepared daily, and twelve repetitions of milk were analysed within four hours after spiking.

Table 2. Antibiotic concentrations used for the detection limit (DL) calculation on microbial inhibitor tests on goat milk

\begin{tabular}{|c|c|c|c|c|c|c|c|c|c|}
\hline \multirow[t]{2}{*}{ Antibiotic } & \multirow{2}{*}{$\begin{array}{c}\text { Test } \\
\text { BRT MRL }\end{array}$} & \multicolumn{7}{|c|}{ Concentrations $(\mu \mathrm{g} / \mathrm{l})$} & \multirow[b]{2}{*}{2.8} \\
\hline & & 0 & 1.0 & 1.3 & 1.6 & 1.9 & 2.2 & 2.5 & \\
\hline \multirow[t]{3}{*}{ Ampicillin } & $\begin{array}{c}\text { Delvotest SP-NT } \\
\text { MCS }\end{array}$ & 0 & 1.3 & 1.6 & 1.9 & 2.2 & 2.5 & 2.8 & 3.1 \\
\hline & Eclipse 100 & 0 & 3.0 & 3.4 & 3.8 & 4.2 & 4.6 & 5.0 & 5.4 \\
\hline & BRT MRL & 0 & 0.7 & 1 & 1.3 & 1.6 & 1.9 & 2.2 & 2.5 \\
\hline \multirow[t]{3}{*}{ Amoxicillin } & $\begin{array}{c}\text { Delvotest SP-NT } \\
\text { MCS }\end{array}$ & 0 & 0.7 & 1 & 1.3 & 1.6 & 1.9 & 2.2 & 2.5 \\
\hline & Eclipse 100 & 0 & 1.3 & 1.6 & 1.9 & 2.2 & 2.5 & 2.8 & 3.1 \\
\hline & BRT MRL & 0 & 5.0 & 7.0 & 9.0 & 11.0 & 13.0 & 15.0 & 17.0 \\
\hline \multirow[t]{3}{*}{ Cloxacillin } & $\begin{array}{c}\text { Delvotest SP-NT } \\
\text { MCS }\end{array}$ & 0 & 5.0 & 7.0 & 9.0 & 11.0 & 13.0 & 15.0 & 17.0 \\
\hline & Eclipse 100 & 0 & 13.0 & 16.0 & 19.0 & 22.0 & 25.0 & 28.0 & 31.0 \\
\hline & BRT MRL & 0 & 0.2 & 0.4 & 0.6 & 0.8 & 1.0 & 1.2 & 1.4 \\
\hline \multirow[t]{2}{*}{ Benzylpenicillin } & $\begin{array}{c}\text { Delvotest SP-NT } \\
\text { MCS }\end{array}$ & 0 & 0.4 & 0.6 & 0.8 & 1.0 & 1.2 & 1.4 & 1.6 \\
\hline & Eclipse 100 & 0 & 1.0 & 1.2 & 1.4 & 1.6 & 1.8 & 2.0 & 2.2 \\
\hline
\end{tabular}




\subsection{Statistical analysis}

To evaluate the effects of the acid $\left(D_{A C}\right)$ or alkaline $\left(D_{A K}\right)$ detergent on the response of the microbial inhibitor tests, the logistic regression model was used:

$$
L_{i j}=\operatorname{Logit}\left[P{ }_{i j}\right]=\beta_{0}+\beta_{1}[a t b]_{i}+\beta_{2} D_{A C}+\beta_{3} D_{A K}+\varepsilon_{i j}
$$

Where: $L_{i j}=$ Logit model; $\left[P_{i j}\right]=$ probability for the response category (positive or negative); $\beta_{0}=$ intercept; $\beta_{1}, \beta_{2}, \beta_{3}=$ parameters estimated for the model; [atb] $]_{i}$ effect of antibiotic concentration $(n=8) ; D_{A C}=$ effect of acid detergent; $D_{A K}=$ effect of alkaline detergent, on the dummy variable (without detergent: $D_{A C}=0, D_{A K}=0$; acid detergent: $D_{A C}=1, D_{A K}=0$; alkaline detergent: $\left.D_{A C}=0, D_{A K}=1\right), \varepsilon_{i j}=$ residual error of model.

The detection limits (DLs) were calculated as the antibiotic concentration resulting in 95\% of positive results (ISO13969/IDF183:2003).

Statistical analysis was performed using Statgraphics Centurion XVI 5.1 (Statpoint Technologies, Inc, Warrenton, VA).

\section{Results and discussion}

\subsection{Effect of detergents in goat milk on the rate of false-positive results of microbial screening tests}

The goat milk samples presented an adequate physico-chemical quality (fat: $4.36 \pm$ $0.12 \%$, protein: $3.61 \pm 0.07 \%$, dry matter: $14.24 \pm 0.28 \%$, and $\mathrm{pH}$ value: $6.66 \pm 0.02$ ) and hygienic-sanitary parameters (SCC: $889 \pm 79 \times 10^{3} \mathrm{cell}^{-\mathrm{ml}^{-1}}$, and BC: $331 \pm 51 \times 10^{3} \mathrm{cell} \cdot \mathrm{ml}^{-1}$ ) to be used as antimicrobial-free milk.

The presence of the acid detergent in goat milk did not affect the response of the microbial inhibitor tests employed, the results were always negative. Moreover, the acid detergent addition decreased the $\mathrm{pH}$ of milk samples, reaching $\mathrm{pH}$ between 5.72 and 5.98 for the highest concentration $(2.5 \mathrm{ml} / \mathrm{l})$ of the five detergents, being lower compared with the average of $\mathrm{pH}$ cited for goat milk (6.5-6.8; Park et al., 2007) and the $\mathrm{pH}$ of the milk before addition of the detergent. These very low $\mathrm{pH}$ values can simulate the effect of acid production, which is produced as a consequence of the metabolism of the microorganism, favouring the change in colour of the indicator present in the medium test.

The alkaline detergent addition in goat milk produced positive results at concentration $\geq$ $2 \mathrm{ml} / \mathrm{l}$ (Table 3). Besides, at these concentrations, the $\mathrm{pH}$ of the milk samples was high, reaching $\mathrm{pH}$ of $9.82-10.80$ for the highest concentrations tested, which could also inhibit the 
growth of the microorganism and thus, prevent the colour change of the test indicator system.

Table 3. Effect of the alkaline detergent concentration in goat milk on microbial screening tests testing residue-free milk

\begin{tabular}{|c|c|c|c|c|c|c|c|c|c|}
\hline \multirow{3}{*}{$\begin{array}{l}\text { Alkaline } \\
\text { detergent }\end{array}$} & \multirow{3}{*}{ Test } & \multicolumn{8}{|c|}{ Positive results (\%) } \\
\hline & & \multicolumn{8}{|c|}{ Concentration $\mathrm{ml} / \mathrm{I}$} \\
\hline & & 0 & 0.5 & 1 & 2 & 4 & 6 & 8 & 10 \\
\hline \multirow{4}{*}{ Basix } & $p H$ & 6.75 & 6.87 & 6.95 & 7.19 & 7.90 & 8.95 & 9.67 & 10.11 \\
\hline & BRT MRL & 0 & 0 & 0 & 0 & 100 & 100 & 100 & 100 \\
\hline & Delvotest SP-NT MCS & 0 & 0 & 0 & 0 & 100 & 100 & 100 & 100 \\
\hline & Eclipse 100 & 0 & 0 & 0 & 0 & 100 & 100 & 100 & 100 \\
\hline \multirow{4}{*}{$\begin{array}{c}\text { Circoaction } \\
\text { AF }\end{array}$} & $\mathrm{pH}$ & 6.67 & 6.79 & 6.85 & 7.14 & 7.69 & 8.31 & 9.38 & 9.82 \\
\hline & BRT MRL & 0 & 0 & 0 & 0 & 100 & 100 & 100 & 100 \\
\hline & Delvotest SP-NT MCS & 0 & 0 & 8.3 & 16.7 & 25 & 100 & 100 & 100 \\
\hline & Eclipse 100 & 0 & 0 & 0 & 0 & 100 & 100 & 100 & 100 \\
\hline \multirow{4}{*}{ Clor FW } & $p H$ & 6.74 & 6.82 & 6.96 & 7.23 & 8.09 & 9.12 & 9.77 & 10.24 \\
\hline & BRT MRL & 0 & 0 & 8.3 & 100 & 100 & 100 & 100 & 100 \\
\hline & Delvotest SP-NT MCS & 0 & 0 & 0 & 0 & 100 & 100 & 100 & 100 \\
\hline & Eclipse 100 & 0 & 0 & 0 & 0 & 100 & 100 & 100 & 100 \\
\hline \multirow{4}{*}{ Grupaclor } & $p H$ & 6.76 & 6.87 & 7.03 & 7.41 & 8.94 & 9.86 & 10.41 & 10.80 \\
\hline & BRT MRL & 0 & 0 & 0 & 0 & 100 & 100 & 100 & 100 \\
\hline & Delvotest SP-NT MCS & 0 & 0 & 8.3 & 100 & 100 & 100 & 100 & 100 \\
\hline & Eclipse 100 & 0 & 0 & 16.7 & 100 & 100 & 100 & 100 & 100 \\
\hline \multirow{4}{*}{ Manobactyl } & $p H$ & 6.76 & 6.87 & 7.00 & 7.41 & 8.38 & 9.53 & 10.13 & 10.37 \\
\hline & BRT MRL & 0 & 0 & 0 & 0 & 100 & 100 & 100 & 100 \\
\hline & Delvotest SP-NT MCS & 0 & 0 & 0 & 0 & 100 & 100 & 100 & 100 \\
\hline & Eclipse 100 & 0 & 0 & 8.3 & 16.7 & 100 & 100 & 100 & 100 \\
\hline
\end{tabular}

These results agree with the results obtained by Zvirdauskiene and Salomskiene (2007) and Salomskiene et al. (2013) who studied the effects of various commercial detergents on the microbial test response in cow milk, and found false positive results at alkaline detergent concentrations equivalent to the dose recommended by the manufactures and above. Although, it should be noted that these high concentrations are very unlikely to be found in practice, even with poor cleaning routines. Also, these authors did not find 
interferences due to the presence of acid detergents in milk. At lower alkaline detergent concentrations ( $\leq 1,000 \mathrm{mg} / \mathrm{l}$ ), Merin et al. (1985) and Salomskiene et al. (2013) did not find any positive results for the Delvotest microbial test; similar results to those obtained for most alkaline detergents tested in goat milk (Table 3). However, Schiffmann et al. (1992) observed doubtful and positive results at very low concentrations $(0.01 \mathrm{mg} / \mathrm{ml})$ using one acid detergent (Calgonit S) and a basic one (Calgonit D) in different versions of the Brilliant Black Reduction Test (BRT).

In conclusion, the presence of alkaline detergents in goat milk at concentrations $\geq 1$ $\mathrm{ml} / \mathrm{l}$, could lead to false positive results in microbial inhibitor tests. From $4 \mathrm{ml} / \mathrm{l}$ on (except for Circoaction AF) all test results were 100\% positive. However, these amounts are not reached if the rinsing of the milking equipment is carried out in an effective manner after cleaning (Reybroeck, 1997).

\subsection{Effect of detergents in goat milk on the penicillin detection capability of microbial screening tests}

Table 4 shows the equations resulting from statistical analysis used to predict the positive results for the penicillins and the detection limits $(D L)$ of the microbial inhibitor tests. The goodness-of-fit test shows that the experimental values are similar to those estimated by the logistic model, suggesting a suitable adjustment of this model. The DLs calculated for microbial tests in detergent-free milk were lower than those indicated by Sierra et al. (2009) in goat milk, which in most cases were closer to MRLs than those calculated in the present study. These differences could be related to modifications carried out by manufacturers to improve the sensitivity of these screening tests.

The presence of acid detergents in goat milk did not affect or slightly increased the sensitivity of the Delvotest SP-NT MCS and Eclipse 100, showing lower concentrations for the DLs than those calculated for detergent-free milk (Table 4). However, in the case of BRT $M R L$, the acid detergent decreased the sensitivity to detect most penicillins in goat milk (Table 4). 
Table 4. Prediction equation responses and detection limits of the microbial screening methods in the presence of penicillins, acid detergent, basic and without detergent

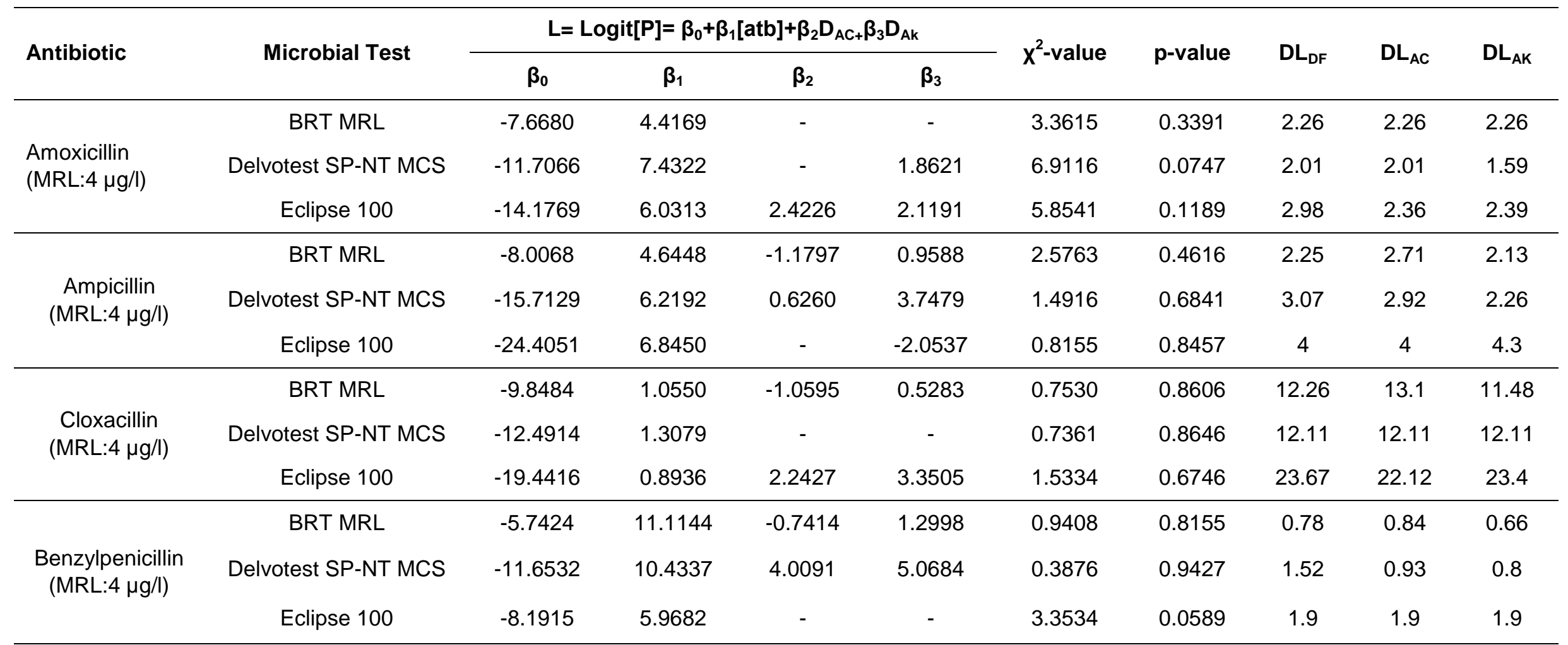

$\mathrm{L}=\ln$ (Probability (+)/1- Probability (+)); [atb]: antibiotic concentration; $\mathrm{D}_{\mathrm{AC}}=$ effect of acid detergent; $\mathrm{D}_{\mathrm{AK}}=$ effect of alkaline detergent, on the dummy variable (without detergent: $D_{A C}=0, D_{A K}=0$; acid detergent: $D_{A C}=1, D_{A K}=0$; alkaline detergent: $D_{A C}=0, D_{A K}=1$ ); $D L_{D F}$ : detergent-free detection limit, $D L_{A C}$ : acid detergent detection limit, $\mathrm{DL}_{\mathrm{AK}}$ : alkaline detergent detection limit; $\mathrm{MRL}$ : Maximum Residue Limit 
The DLs calculated for penicillins in milk containing alkaline detergent were below or equal to those obtained in detergent-free milk (Table 4), except for ampicillin in the Eclipse 100 , which was slightly higher (4.3 vs $4.0 \mu \mathrm{g} / \mathrm{l})$. In spite of the statistical significant effect of the presence of detergents in goat milk on the detection capability of the microbial tests, the DLs calculated were generally below MRLs established for each antimicrobial substance (Regulation (EC) No 37/2010). Therefore, the presence of acid or basic detergent at concentrations equivalents to $0.05 \mathrm{ml} / \mathrm{l}$ does apparently not have any influence on the detection of raw milk containing penicillins above the MRL by microbial inhibitor tests as applied in goat milk quality control programmes.

However, it is not known if a higher concentration of detergents in milk could have a serious effect on the detection capability of the methods employed to detect antibiotics in milk. No reference concerning the effect of detergents on the sensitivity of inhibitor tests for the penicillins or other antimicrobial agents was found; therefore the comparison of the results with those of other authors is not possible.

\section{Conclusions}

The response of microbial screening tests in goat milk can be affected by the presence of alkaline detergents at high concentrations equal or greater than $2 \mathrm{ml} / \mathrm{l}$. However, acid detergents did not produce any interference. Small amounts of acid and alkaline detergents in goat milk $(\leq 0.05 \%)$ do not influence the sensitivity of the BRT MRL, Delvotest SP-NT MCS and Eclipse 100 methods to detect penicillins. To avoid alterations in the milk quality and interferences in microbial screening tests employed in control programmes, the implementation of proper cleaning procedures to minimise the presence of detergent residues in milk is crucial.

\section{Acknowledgements}

This work forms part of the Project AGL 2009-11524 financed by the Ministry of Science and Innovation (Madrid, Spain) and the Generalitat Valenciana ACOMOP/2012/164 (Valencia, Spain). The authors are grateful to AiM Analytik in MilchProduktions-und Vertriebs-GmbH (Munich, Germany), DSM Food Specialties (Delft, the Netherlands), ZEULAB S.L. Zaragoza, Spain) for their technological support.

\section{References}

Adetunji, V.O. 2011. Effects of processing on antibiotics residues (streptomycin, penicillin-G and tetracycline) in soft cheese and yoghurt processing lines. Pak. J. Nutr.10: 792-795. 
Andrew, S.M. 2001. Effect of composition of colostrum and transition milk from Holstein heifers on specificity rates of antibiotic residue tests. J. Dairy Sci. 84: 100-106.

Alanis, A.J. 2005. Resistance to antibiotics: are we in the Post-Antibiotic Era? Arch. Med. Res. 36: 697-705.

Commission Regulation (EU) No 470/2009 of the european parliament and of the council of 6 May 2009 laying down Community procedures for the establishment of residue limits of pharmacologically active substances in foodstuffs of animal origin, repealing Council Regulation (EEC) No 2377/90 and amending Directive 2001/82/EC of the European Parliament and of the Council and Regulation (EC) No 726/2004 of the European Parliament. Off. J. Eur.Comm 2009 L152: 11-22.

Commission Regulation (EU) No 37/2010 of 22 December 2009 on pharmacologically active substances and their classification regard Council of 29 April 2004 on the hygiene of foodstuffs. Off. J. Eur.Comm 2009 L15: 1-72.

Demoly, P., Romano, A. 2005 Update on beta-lactam allergy diagnosis. Curr. Allergy Asthm. R. 5: 9-14.

Dunsmore, D.G., Makin, D., Arkin R 1985 Effect of residues of five disinfectants in milk on acid production by strains of lactic starters used for Cheddar cheese making and on organoleptic properties of the cheese. J. Dairy Res. 52: 287-297.

Fabre, J.M., Moretain, J.P., Ascher, F., Brouillet, O., Berthelot, X. 1995. Main causes of inhibitors in milk. A survey in one thousand French dairy farms. In: Residues of Antimicrobial Drugs and other Inhibitors in Milk. IDF S.I. 9505: 27-31. International Dairy Federation, Brussels, Belgium.

Guirguis, N., Hickey, M.W. 1987. Factors affecting the performance of thermophilic starters. I. Sensitivity to dairy sanitizers. II. Sensitivity to the lactoperoxidase system. Aust. J. Dairy Technol. 42:11-26.

International Dairy Federation 2010 Current situation and compilation of commercially available screening methods for the detection of inhibitors/antibiotics residues in milk. FIL- IDF Standard No. 442, International Dairy Federation, Brussels, Belgium.

ISO/IDF. 2003. Milk and milk products- Guidelines for a standardized description of microbial inhibitor tests. IDF Standard No 183:2003. International Dairy Federation, Brussels, Belgium. 
Merin, U., Rosenthal, I., Bernstein, S., Popel, G. 1985. The effect of residues of detergents and detergents-sanitizers on the performance of antibiotic test and the organoleptic quality of milk. Le Lait. 65: 163-167.

Molina, M.P., Althaus, R.L., Balasch, S., Torres, A., Peris, C. Fernandez, N. 2003. Evaluation of screening test for detection of antimicrobial residues in ewe milk. J. Dairy Sci. 86: 1947-1952.

Packham, W., Broome, M.C., Limsowtin, G.K.Y., Roginski. H. 2001. Limitations of standard antibiotic screening assays when applied to milk for cheesemaking. Aust. J. Dairy Technol. 5: 15-18.

Park, Y.W., Juárez, M., Ramos, M. Haenlein, G.F.W. 2007. Physico-chemical characteristics of goat and sheep milk. Small Rumin. Res. 68: 88-113.

Petrova, N., Dimitrov, N. 1993. Effect of alkaline combined agents on the activity of the bacteria starter (Lactococcus lactis and Lactobacillus casei L116-40) used for manufacturing white brined cheese from ewe's milk. Food Res. Int. 26: 327-332.

Pontefract, R.D. 1991. Bacterial adherence: its consequences in food processing. Can. I. Food Sc. Tech. J. 24: 113-117.

Reybroeck, W. 1997. Detergents and disinfectants. In Residues and Contaminants in Milk and Milk Products, Vol. 9701, pp. 109-119. International Dairy Federation Brussels, Belgium.

Salomskiene, J., Macioniene, I., Zvirdauskiene, R., Jonkuviene, D. 2013. Impact of the residues of detergents and disinfectants used in dairy farms on the results of inhibitor tests for raw mik. Adv. Biosci. Biotechnol. 4: 266-277.

Sanders, P., Bousquet-Melou, A., Chauvin, C., Toutain, P.L. 2011. Utilisation des antibiotiques en élevage et enjeux de santé publique. Inra Prod. Anim. 24: 199-204.

Schiffmann, A.P., Schütz, M., Wiesner, H. 1992. False negative and positive results in testing for inhibitory substances in milk. Factors influencing the brilliant black reduction test (BRT). Milchwissenschaft. 47: 770-772.

Sierra, D., Sánchez, A., Contreras, A., Luengo, C., Corrales, J.C., de la Fe, C., Guirao, I., Morales, C.T., Gonzalo, C. 2009. Detection limits of four antimicrobial residue screening test for $\beta$-lactams in goat's milk. J. Dairy Sci. 92: 3585-3591.

Zvirdauskiene, R., Salomskiene, J. 2007. An evaluation of different microbial and rapid test for determining inhibitors in milk. Food Control. 18: 541-547. 


\title{
Interference of cleaning products for home use in goat milk on microbial inhibitor tests for screening for antibiotics
}

\begin{abstract}
Cleaning and disinfection of dairy equipment is an essential task to ensure the hygienic quality of milk. Occasionally, some farmers use non-specific products as well as washing-up liquid and disinfectants for home use, especially when milk tanks are cleaned manually.

Residues of detergents and disinfectants in milk may interfere in microbial inhibitor tests used for screening for antibiotics in milk. Therefore, the aim of this study was to evaluate the effect of cleaning products for home use in goat milk on the response of microbial inhibitor tests (BRT MRL, Delvotest SP-NT MCS, and Eclipse 100). Eight concentrations of five washing-up liquids and one disinfectant $(0-1 \%)$ were added to antimicrobial-free goat milk to evaluate their interference in microbial inhibitor test results. Also, the detection limits for penicillins of microbial inhibitor tests was studied in milk with and without cleaning products, calculating the dose-response curve with eight concentrations of amoxicillin, ampicillin, benzylpenicillin and cloxacillin, respectively. The results showed that the presence of washing-up liquid at concentrations $\geq 1 \mathrm{ml} / \mathrm{l}$ in milk resulted in positive results in microbial inhibitor tests. In particular, the product containing sodium laureth sulphate and ethanol produced the largest number of false positive results. The presence of disinfectant based on sodium hypochlorite did not affect the response of microbial tests for any concentration tested. The detection limits of the screening tests for penicillins were not modified substantially by cleaning product based in sodium laureth sulphate and ethanol. Residues of cleaning agents in milk can be avoided when approved detergents and disinfectants are used and the proper cleaning procedures are followed.
\end{abstract}

Keywords: Washing-up liquid, disinfectants, microbial tests, goat milk. 


\section{Introduction}

European Regulation (EC) No 853/2004 stipulates the specific hygiene rules for raw milk from different species. Thus, food business operators are legally obliged to initiate procedures to ensure that raw milk is not supplied to the market if it contains antibiotic residues above maximum residue limits established by Commission Regulation (EU) No $37 / 2010$.

In milk control laboratories the screening of antibiotic residues is mainly carried out using microbial inhibitor tests, which are inexpensive, easy to use on a large scale and do not require specialised equipment. However, they are non-specific for antimicrobial agents and may be susceptible to interfering substances in raw milk such as colostrum (Romero et al. 2014a), naturally occurring inhibitors (Carlsson et al., 1989), fatty acids (Mäyrä-Mäkinen, 1990) or cleaning and disinfection agents (Romero et al., 2014b) among others, causing noncompliant results (false positive) for antibiotic-free milk samples.

Studies on the occurrence of false positive results in goat milk are very limited and offer results highly variable ranging from $0 \%$ (no false positives) to $7 \%$ (Zeng et al., 1996; Contreras et al., 1997; Beltrán et al., 2007, 2015) generating serious economic consequences for farmers and the dairy industry.

In Europe, goat milk production (2,536,773 tonnes; FAOSTAT, 2012) is mainly located around the Mediterranean, and plays an important economic, environmental and sociological role, especially in unfavourable landscapes found in many countries such as France, Italy, Spain, and Greece (Dubeuf and Le Jaouen, 2005). In most of these countries, although intensification of the sector has taken place in recent years, the traditional system is still widespread being extensive or semi-intensive, characterised by small-sized farms, traditional technology, the use of local breeds, scarce economic and human resources and farmers with relatively little training (Dubeuf et al., 2010).

Goat milk production has traditionally been destined for the manufacturing of artisan cheeses at farm-level or in small-scale dairies, often from raw milk, and therefore, good hygienic milk quality is paramount.

One of the basic principles for the hygienic production of raw milk is the cleaning and disinfection of milking machine equipment and milk storage tanks in farms. After use, all surfaces in contact with milk must be cleaned and, when necessary disinfected properly to prevent the proliferation of microorganisms that can cause milk contamination (Pontefact, 1991). 
Errors related to the dosage of the cleaning products and inadequate post-rinsing may lead to residues of detergents and disinfectants in milk, likely to interfere in the activity of starter cultures (Vallado and Sandine, 1994), alter the organoleptic characteristics of milk (Merin et al., 1985), pose toxicity in consumers (Reybroeck, 1997) and cause non-compliant results in microbial screening tests (Fabre et al., 1995).

In small-sized goat farms and dairies, automated cleaning processes are hardly found (Reinemann et al., 2003) and many cleaning processes are carried out manually. Moreover, in some cases at farm level or in small units, non-recommended products such as washingup liquids and disinfectants for home use are employed, especially when cleaning milk storage tanks.

Therefore, the aim of this study was to analyse the effect of such cleaning products on the microbial inhibitor test response in goat milk.

\section{Material and methods}

\subsection{Goat milk samples}

Antimicrobial-free milk samples obtained from mixed milk of 20 Murciano-Granadina goats in mid-lactation (Universitat Politècnica de València, Spain) were used according to ISO/IDF (2003) criteria. Animals had a good health status and did not receive any veterinary drugs during the entire lactation period. The milk samples were analysed using MilkoScan 6000 (Foss, Hillerød, Denmark) to determine composition (fat, protein and total solids); somatic cell count (SCC) was obtained by Fossomatic 5000 (Foss); bacterial count (BC) was carried out with Bactoscan FC (Foss) and the $\mathrm{pH}$ value was measured by a conventional pH meter (Crison, Barcelona, Spain) to check the physiochemical quality of the milk samples.

\subsection{Microbial inhibitor tests}

The microbial inhibitor tests employed in this study were: BRT MRL (Analytik in Milch Produktions-und Vertriebs-GmbH, Munich, Germany), Delvotest SP-NT MCS (DSM Food Specialties, Delft, the Netherlands) and Eclipse 100 (ZEULAB S.L., Zaragoza, Spain). All tests were used according to the manufacturer's instructions. Negative (antimicrobial-free milk) and positive (antimicrobial-free milk spiked with $4 \mu \mathrm{g} / \mathrm{kg}$ of benzylpenicillin) controls were included in each test. The results were interpreted by three trained technicians visually as 'negative' (yellow) and 'positive' (blue or purple). 


\subsection{Spiked milk samples with cleaning products}

Five domestic washing-up liquid and one disinfectant were used: anionic tensioactive 515\%-amphoteric tensioactive < 5\%) (Carrefour; produced and bottled by McBride S.A., Barcelona, Spain for Carrefour supermarkets), sodium laureth sulphate 5-10\%benzenesulfonic acid 5-10\% (Coral; Reckitt Benckiser, S.L., Barcelona, Spain), sodium laureth sulphate 20-30\%-ethanol 1-5\% (Fairy; Procter \& Gamble S.A., Madrid, Spain), ethoxylated fatty alcohol 5-10\% (Mistol; Henkel Ibérica S.A., Barcelona, Spain), sodium hydroxide < 1\% (Tenaz; Industrias Vijusa S.L., Valencia, Spain) and sodium hypochlorite < 5\% (Alin bleach; Elaboraciones Químicas del Sur S.A., Malaga, Spain).

To evaluate the effect of the cleaning products and disinfectant on the false positive results of the microbial tests employed, antibiotic-free goat milk samples were spiked with concentrations of: $0,0.5,1,2,4,6,8,10 \mathrm{ml} / \mathrm{l}$ and tested twelve times each.

To assess the effect of home use cleaning products on the detection capability of microbial screening tests for penicillins, the detection limits (DLs) for ampicillin, amoxicillin, cloxacillin and benzylpenicillin were calculated following ISO/IDF (2003) recommendations. A washing up liquid containing sodium laureth sulphate and ethanol (Fairy) was added to antibiotic-free goat milk at a concentration of $0.5 \mathrm{ml} / \mathrm{l}$. Goat milk samples without detergents were used as control.

The antibiotics selected were supplied by Sigma-Aldrich (Madrid, Spain): amoxicillin (31586), ampicillin (A-9518), cloxacillin (C-9393), and benzylpenicillin (PENNA). All the antibiotic standard solutions were prepared daily, and milk samples (with or without detergents) were spiked with antibiotics at different concentrations $(n=8)$. Twelve replicates of spiked milk samples were analysed within four hours after spiking.

\subsection{Statistical analysis}

To evaluate the effect of the presence of the cleaning products on the microbial test response a logistic regression model was applied:

$$
L_{i j k}=\operatorname{Logit}\left[P_{i j}\right]=\beta_{0}+\beta_{1}[A C]_{i}+\beta_{2}[C P]_{j}+\varepsilon_{i j k}
$$

Where: $L_{i j k}=$ Logit model; $\left[P_{i j}\right]=$ probability for the positive response; $\beta_{0}=$ intercept; $\beta_{1}$, $\beta_{2}=$ parameters estimated for the model; $[A C]_{i}=$ effect of antibiotic concentration $(n=8)$ and $[C P]_{j}=$ effect of cleaning product on the dummy variable (milk without cleaning product: $\mathrm{CP}=$ 0 and with cleaning product $\mathrm{CP}=1$ ) and $\varepsilon_{\mathrm{ijk}}=$ residual error of model. 
The detection limits (DLs) for penicillins were calculated from the regression equations obtained, as the antibiotic concentration giving 95\% of positive results (ISO/IDF, 2003). Statistical analysis was performed using Statgraphics Centurion XVI 5.1 (Statpoint Technologies, Inc, Warrenton, VA).

\section{Results and discussion}

The results obtained for washing-up liquids and disinfectant in goat milk vary according to the type of product and the microbial inhibitor test employed (Table 1). It was observed that the Eclipse 100 test was less sensible to the presence of washing-up liquids than the BRT MRL and Delvotest SP-NT MCS tests.

Regarding home use cleaning products, the washing-up liquid containing sodium laureth sulphate and ethanol (Fairy) had a greater effect on all microbial tests considered, even at a relatively low concentration $(1 \mathrm{ml} / \mathrm{l})$. The positive results obtained can be explained by its composition including ethanol, considered an antimicrobial substance (Oh and Marshall, 1993) which may inhibit the growth of the test microorganism (Geobacillus stearothermophilus var. calidolactis). Moreover, it was the only detergent that significantly changed the $\mathrm{pH}$ of the milk samples reaching values of 6.96 at the highest concentration tested $(10 \mathrm{ml} / \mathrm{l})$. These $\mathrm{pH}$ values are higher than the average $\mathrm{pH}$ cited for MurcianoGranadina breed (6.72 \pm 0.1 ; López et al., 1999). As there is no information about the effect of washing-up liquids on the responses of microbial inhibitor screening tests, it is impossible to compare our results with those of other authors.

With respect to disinfectants, any tested concentration of sodium hypochlorite (Alin bleach) altered the microbial test response. All the results were classified as negative. Neither did Merin et al. (1985) indicate positive results in the Delvotest using milk from cows spiked with sodium hypochlorite at a high concentration (25 mg/l).

When cleaning and disinfection procedures recommended by manufactures are followed, and milk equipment is rinsed in an effective manner, detergent and disinfectant residues in milk are usually below $2 \mathrm{mg} / \mathrm{kg}$ (Reybroeck, 1997). Washing-up liquids and disinfectants for home use are not indicated for dairy equipment, and do not present a recommended dose for use or time for proper rinsing; therefore, they might pose a risk for residues in milk. 
Table 1. Effect of home use cleaning products in goat milk on the results of microbial inhibitor tests

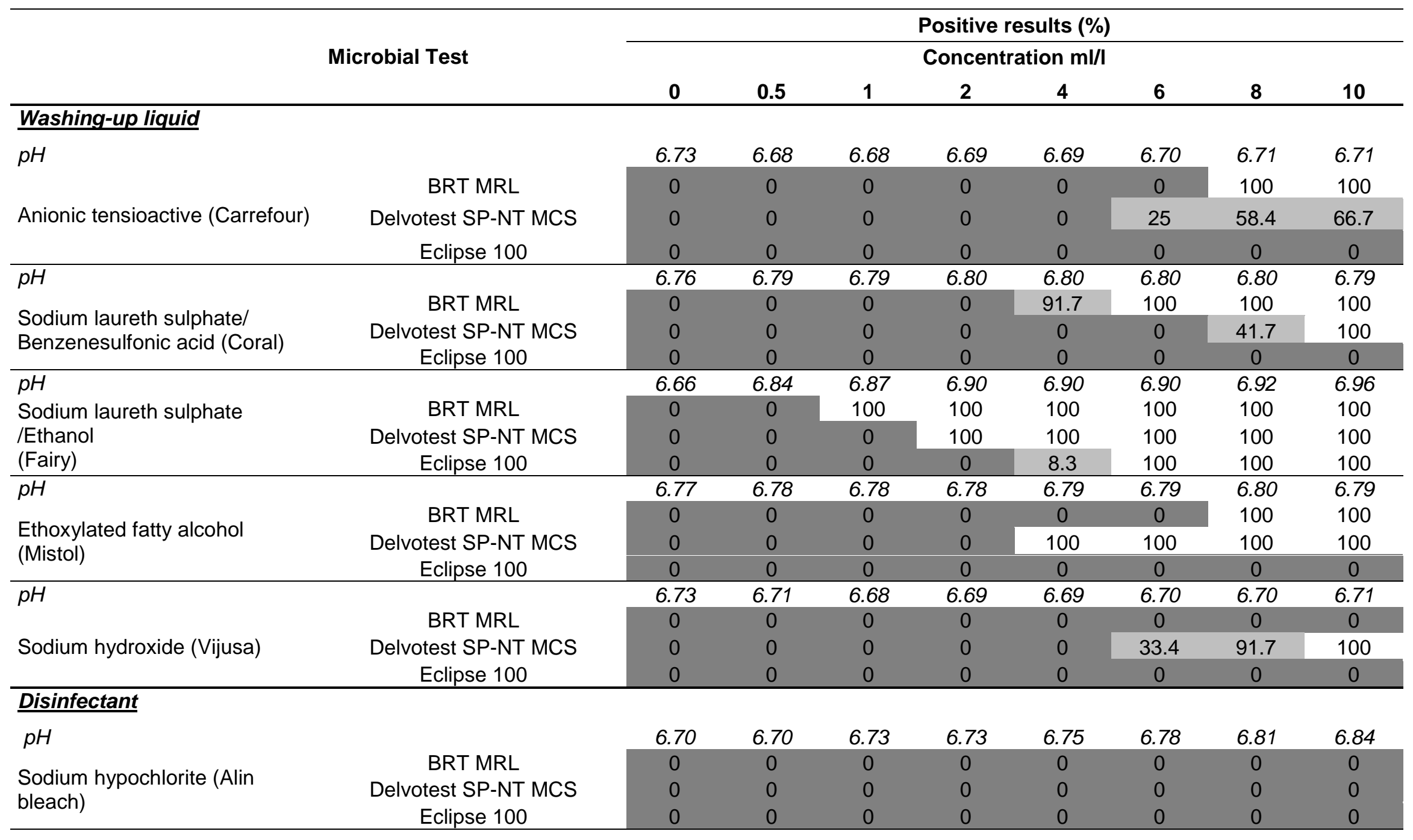


The prediction equations of positive results for the microbial screening test used for the penicillins (amoxicillin, ampicillin, benzylpenicillin and cloxacillin, respectively) in goat milk with and without washing-up liquid (sodium laureth sulphate and ethanol; Fairy) are shown in Table 2. The goodness-of-fit test shows that the experimental values are similar to those estimated by the logistic model, suggesting a suitable adjustment of this model.

Table 2. Prediction equations of the microbial screening methods in the presence of penicillins and washing-up liquid (sodium laureth sulphate and ethanol; Fairy)

\begin{tabular}{|c|c|c|c|c|c|c|}
\hline \multirow{2}{*}{ Antibiotic } & \multirow{2}{*}{ Microbial Test } & \multicolumn{3}{|c|}{$L=\beta_{0}+\beta_{1}[A C]+\beta_{2}[C P]$} & \multirow{2}{*}{$x^{2}$-value } & \multirow{2}{*}{$p$-value } \\
\hline & & $\beta_{0}$ & $\beta_{1}$ & $\beta_{2}$ & & \\
\hline \multirow{3}{*}{$\begin{array}{l}\text { Amoxicillin } \\
\text { (MRL:4 } \mu \mathrm{g} / \mathrm{l} \text { ) }\end{array}$} & BRT MRL & -10.8844 & 6.1299 & 0.1540 & 1.7826 & 0.6187 \\
\hline & Delvotest SP-NT MCS & -13.1484 & 8.3467 & 1.4677 & 2.9851 & 0.3939 \\
\hline & Eclipse 100 & -13.8602 & 5.8964 & 3.5673 & 6.9142 & 0.0747 \\
\hline \multirow{3}{*}{$\begin{array}{l}\text { Ampicillin } \\
\text { (MRL:4 } \mu \mathrm{g} / \mathrm{l} \text { ) }\end{array}$} & BRT MRL & -6.7899 & 3.9486 & -1.1200 & 4.3851 & 0.2228 \\
\hline & Delvotest SP-NT MCS & -18.8816 & 7.4768 & 2.8050 & 0.9154 & 0.8217 \\
\hline & Eclipse 100 & -32.5715 & 9.1409 & 1.4944 & 0.7244 & 0.8674 \\
\hline \multirow{3}{*}{$\begin{array}{l}\text { Benzylpenicillin } \\
\text { (MRL:4 } \mu \mathrm{g} / \mathrm{l}) \text { ) }\end{array}$} & BRT MRL & -4.4721 & 8.6634 & -2.4603 & 0.8070 & 0.8478 \\
\hline & Delvotest SP-NT MCS & -9.2267 & 8.2569 & 2.6328 & 3.5038 & 0.3203 \\
\hline & Eclipse 100 & -5.9579 & 5.6122 & -0.3899 & 2.2425 & 0.5236 \\
\hline \multirow{3}{*}{$\begin{array}{l}\text { Cloxacillin } \\
\text { (MRL:4 } \mu \mathrm{g} / \mathrm{l}\end{array}$} & BRT MRL & -6.1169 & 0.6577 & 0.2261 & 0.9343 & 0.8171 \\
\hline & Delvotest SP-NT MCS & -14.1612 & 1.4161 & 0.4824 & 1.1639 & 0.7617 \\
\hline & Eclipse 100 & -16.1524 & 0.7426 & 1.8607 & 0.3650 & 0.9474 \\
\hline
\end{tabular}

$\mathrm{L}=\ln ($ Probability $(+) / 1$ - Probability $(+))$; $[\mathrm{AC}]$ : antibiotic concentration and $[\mathrm{CP}]=$ effect of cleaning product on dummy variable (milk without cleaning product: $\mathrm{CP}=0$ and with cleaning product $\mathrm{CP}=1$

The detection limits (DLs) for penicillins (Table 3) calculated from the logistic regression equations were below the maximum residue limits (MRLs) established by legislation for these substances (Commission Regulation (EU) No 37/2010) and also lower than the DLs calculated by Sierra et al. (2009) in goat milk highlighting the greater sensitivity of the current versions of these screening tests as a result of the improvements made by manufacturers in recent years. 
Table 3. Effect of the presence of washing-up liquid (sodium laureth sulphate and ethanol; Fairy) at concentration of $0.05 \mathrm{ml} / \mathrm{l}$ in goat milk on the detection capability of microbial inhibitor tests for penicillins

\begin{tabular}{|c|c|c|c|c|c|c|c|c|}
\hline \multirow{2}{*}{$\begin{array}{l}\text { Microbial } \\
\text { Tests }\end{array}$} & \multicolumn{2}{|c|}{ 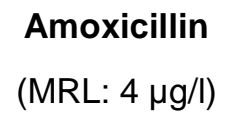 } & \multicolumn{2}{|c|}{$\begin{array}{l}\text { Ampicillin } \\
\text { (MRL: } 4 \mu \mathrm{g} / \mathrm{l})\end{array}$} & \multicolumn{2}{|c|}{$\begin{array}{c}\text { Benzylpenicillin } \\
\text { (MRL: } 4 \mu \mathrm{g} / \mathrm{l})\end{array}$} & \multicolumn{2}{|c|}{$\begin{array}{c}\text { Cloxacillin } \\
\text { (MRL: } 30 \mu \mathrm{g} / \mathrm{l})\end{array}$} \\
\hline & DL & $\mathrm{DL}_{\mathrm{D}}$ & DL & $\mathrm{DL}_{\mathrm{D}}$ & DL & $D_{L_{D}}$ & $\mathrm{DL}$ & $D_{L_{D}}$ \\
\hline BRT MRL & 2.26 & 2.23 & 2.47 & 2.75 & 0.86 & 1.14 & 13.78 & 13.43 \\
\hline $\begin{array}{l}\text { Delvotest } \\
\text { SP-NT MCS }\end{array}$ & 1.93 & 1.75 & 2.92 & 2.54 & 1.47 & 1.16 & 12.08 & 11.74 \\
\hline Eclipse 100 & 2.85 & 2.24 & 3.89 & 3.72 & 1.59 & 1.66 & 25.72 & 23.21 \\
\hline
\end{tabular}

MRL: Maximum Residue Limit; DL: Detection Limit of detergent-free milk $(\mu \mathrm{g} / \mathrm{l}) ; \mathrm{DL}_{\mathrm{D}}$ : Detection Limit milk with detergent $(\mu \mathrm{g} / \mathrm{l})$

Although the presence of washing-up liquid at a concentration of $0.5 \mathrm{ml} / \mathrm{l}$ in goat milk had a significant effect on the microbial test sensitivity for all the penicillins analysed, the detection of drug residues at safe levels was not compromised because the DLs were below their respective MRLs in all cases. In general, similar results were obtained by Romero et al. (2014b) using approved cleaning products (acid and alkaline detergents) at concentration of $0.5 \mathrm{ml} / \mathrm{l}$ in goat milk.

\section{Conclusion}

Microbial screening test response can be affected by the presence of washing-up liquids for home use in goat milk at concentrations $\geq 1 \mathrm{ml} / \mathrm{l}$, especially if antimicrobial substances such as ethanol are included in their composition. However, the presence of up $10 \mathrm{ml} / \mathrm{l}$ of disinfectants based on sodium hypochlorite $(<5 \%)$ does not seem to affect the test responses.

The presence of cleaning product for home use based on sodium laureth sulphate and ethanol at concentrations of $0.5 \mathrm{ml} / \mathrm{l}$ modify the microbial test sensitivity but does not compromise the detection of penicillin residues in goat milk at safe levels. Residues of cleaning products in milk can be avoided when home-use detergents and disinfectants are used for the cleaning and disinfection for milking equipment and milk storage tanks by following proper cleaning procedures. 


\section{Acknowledgements}

This work forms part of the Project AGL 2009-11524 financed by the Ministry of Science and Innovation (Madrid, Spain). The authors are grateful to Analytik in MilchProduktions-und Vertriebs-GmbH (Munich, Germany), DSM Food Specialties (Delft, the Netherlands), ZEULAB S.L. Zaragoza, Spain) for their technological support.

\section{References}

Beltrán, M.C., Altahus, R.L., Berruga, I., Molina, A., Molina, M.P. 2007. Microbiological methods for detection of inhibitors in goat milk. pp 147-149. In: Acts of the $5^{\text {th }}$ International Symposium on the Challenge to Sheep and Goats Milk Sectots, Alghero, Italy.

Beltrán, M.C., Berruga, M.I., Molina, A., Althaus, R.L., Molina M.P. 2015. Performance of the current microbial tests for screening antibiotic in sheep and goat Milk. Int. Dairy J. 41: 1315.

Carlsson, A., Björck I., Persson, K. 1989. Lactoferrin and lysozyme in milk during acute mastitis and their inhibitory effect in Delvotest P. J. Dairy Sci. 72: 3166-3175.

Commission Regulation (EU) No 37/2010 of 22 December 2009. On pharmacologically active substances and their classification regard Council of 29 April 2004 on the hygiene of foodstuffs. Off. J. Eur.Comm 2009 L15: 1-72.

Contreras, A., Paape, M.J., Di Carlo, A.L., Miller, R.H., Rainard, P. 1997. Evaluation of selected antibiotic residue screening tests for milk from individual goats. J. Dairy Sci. 80: 1113-1118.

Dubeuf, J.P., Le Jaouen, J.C. 2005. The sheep and goat dairy sectors in the European Union: present situation and stakes for the future. IDF S.I. 501: 1-6. International Dairy Federation, Brussels, Belgium.

Dubeuf, J.P., Ruiz-Morales, F.A., Castel-Genis J.M. 2010. Initiatives and projects to promote the Mediterranean local cheeses and their relations to the development of livestock systems and activities. Small Rumin. Res. 93: 67-75.

Fabre, J.M., Moretain, J.P., Ascher, F., Brouillet, O., Berthelot, X. 1995. Main causes of inhibitors in milk. A survey in one thousand French dairy farms. In: Residues of Antimicrobial Drugs and other Inhibitors in Milk. IDF S.I. 9505: 27-31. International Dairy Federation, Brussels, Belgium. 
FAOSTAT, 2012. Food and Agriculture Organization of the United Nations, Available at: http//faostat.fao.org (online, 21.8.2012).

ISO/IDF. 2003. Milk and milk products- Guidelines for a standardized description of microbial inhibitor tests. IDF Standard No 183: 2003. International Dairy Federation, Brussels, Belgium.

López, M.B., Jordan, M.J., Granados, M.V., Fernández, J.C., Castillo, M., Laencina, J. 1999. Viscosity changes during rennet coagulation of Murciano-Granadina goat milk. Int, J. Dairy Technol. 52: 102-106.

Mäyrä-Mäkinen A. 1990. T-101 test for antibiotic residues in milk. Scand. Dairy Inf. 2: 38-39.

Merin, U., Rosenthal, I., Bernstein, S., Popel, G. 1985. The effect of residues of detergents and detergents-sanitizers on the performance of antibiotic test and the organoleptic quality of milk. Le Lait. 65: 163-167.

Oh, D.H., Marshall, D.L. 1993 Antimicrobial activity of ethanol, glycerol monolaurate of lactic acid against Listeria monocytogenes. Int. J. Food Microbiol. 20: 239-246.

Pontefract, R.D. 1991. Bacterial adherence: its consequences in food processing. Can. I. Food Sci. Tech. J. 24: 113-117.

Reinemann, D.J., Wolters, G.M.V.H., Billon, P., Lind, O., Rasmussen, M.D. 2003. Review of practices for cleaning and sanitation of milking machines. IDF Bull 381: 32-50. International Dairy Federation, Brussels, Belgium.

Regulation (EC) No 853/2004 of the European Parliament and of the Council of 29 April 2004 laying down specific hygiene rules for on the hygiene of foodstuffs. Off. J. Eur. Union L139: 55-205.

Reybroeck, W. 1997. Detergents and disinfectants. In: Residues and Contaminants in Milk and Milk Products. IDF S.I. 9701: 109-119. International Dairy Federation, Brussels, Belgium.

Romero, T., Beltrán, M.C., Althaus, R.L., Molina, M.P. 2014a. Effect of the presence of colostrum on microbial screening methods for antibiotic detection in goats' milk. Small Rumin Res. 121: 376-381.

Romero, T., Beltrán, M.C., Althaus, R.L., Molina, M.P. 2014b. Detection of antibiotics in goat's milk: effect of detergents on the response of microbial inhibitor tests. J. Dairy Res. 81: $372-377$. 
Sierra, D., Sánchez, A., Contreras, A., Luengo, C., Corrales, J.C., de la Fe, C., Guirao, I., Morales, C.T., Gonzalo, C. 2009. Detection limits of four antimicrobial residue screening test for $\beta$-lactams in goat's milk. J. Dairy Sci. 92: 3585-3591.

Vallado, M., Sandine, W.E. 1994. Quaternary amonium compund in milk: detection by reverse-phase high performace liquid chromatography and their effect on starter growth. J. Dairy Sci. 77: 1509-1514.

Zeng, S.S., Escobar, E.N., Brown-Crowder, I. 1996. Evaluation of screening tests for detection of antibiotics in goat milk. Small Rumin. Res. 21: 155-160. 



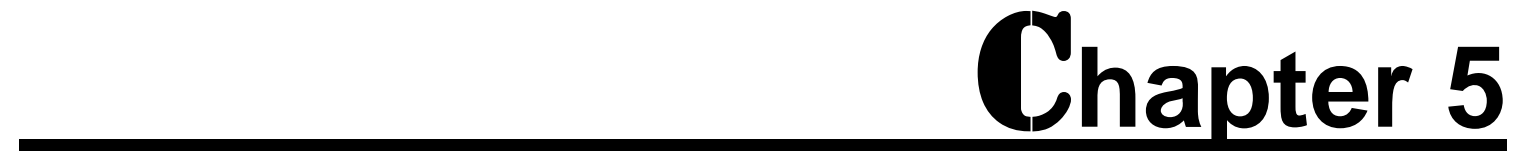

Effect of antiparasitic drugs in goat milk on the incidence of positive results in microbial inhibitor tests 



\title{
Antiparasitic drugs in goat milk: in vitro effect on the response of microbial tests for screening antibiotic residues
}

\begin{abstract}
Microbial inhibitor tests are widely used to screen the presence of antibiotic residues in milk; however they are non-specific and may be affected by different substances capable of inhibiting the growth of the test microorganism. Thus, the objective of this study was to determine the effect of the presence of antiparasitic drugs in goat milk on the microbial screening test response. Raw antibiotic-free milk from Murciano-Granadina goats was spiked with eight different concentrations of seven antiparasitic substances belonging to different groups of parasiticides (albendazole, closantel, diclazuril, febendazole, levamisole, diazinon and ivermectin). Twelve replicates of each concentration were analysed by three microbial inhibitor tests: BRT MRL, Delvotest SP-NT MCS and Eclipse 100. The results were interpreted visually as either negative or positive. Using a logistic regression model, the concentration of the antiparasitic substances producing 5, 10 and 50\% of positive results in the microbial screening tests was determined. The Eclipse 100 test was only influenced by a range of higher concentrations of antiparasitic agents in the milk. Conversely, the BRT MRL test response was the most affected, presenting interferences by lower drug concentrations. Closantel, an anthelmintic, was the endoparasiticide that produced interference in all the microbial tests from low concentrations on (but still in the ppm-range), while higher concentrations of levamisole were required to produce non-compliant results. Diazinon, an ectoparasitic, was also able to produce interference at relatively low concentrations and ivermectin, an endectocide, should be present in relatively high concentrations to cause interference. Results obtained in this study indicate that microbial inhibitor tests for screening antibiotics can be affected by antiparasitic drugs in goat milk by high concentrations. However, carrying out in vivo studies using infested animals treated with different antiparasitic substances would be desirable to evaluate the effect of antiparasitic agents in milk on the response of microbial inhibitor tests.
\end{abstract}

Key words: goat milk, antiparasitic agents, inhibitors, microbial tests. 


\section{Introduction}

In recent years, the intensification of milk production in small ruminants has been associated with enhanced vulnerability to parasitic infections (Plant and Cristopher, 2011). In addition, increasing ambient temperatures together with decreased humidity caused by climate change, have favoured the development of parasites, incrementing the virulence and transmission periods of their diseases (Morgan and Wall, 2009).

Parasites usually cause negative effects in dairy livestock, such as diarrhoea, anaemia, stunted body development and/or a significant reduction of milk production (Hoste and Chartier, 1998; Fthenakis et al., 2000; Walton and Currie, 2007). The most important endoparasitoses affecting dairy goats include parasitic gastroenteritis caused by gastrointestinal nematodes and coccidiosis caused by protozoan parasites. Other internal parasites are Cryptosporidium, adult tapeworms and several metacestodes and insect larvae. Regarding ectoparasites, these can permanently be found on goats (i.e. mites and lice) or only when animals come to the feeder (i.e. ticks and flies).

The use of antiparasitic agents in the treatment and prevention of parasitic diseases in dairy goats is necessary to ensure the profitability of farms. Antiparasitic drugs are classified according to the type of parasite they are applied against, i.e. endoparasiticides, ectoparasiticides and endectocides. The endoparasiticide group includes anthelmintics such as albendazole, closantel and levamisole; and antiprotozoal agents such as diclazuril, nitramide and dimetridazole. On the other hand, ectoparasiticides are classified into different groups according to their chemical structure. Organochlorines, organophosphates, macrolide lactones and amidines have to be particularly mentioned and within these families, cypermethrin, amitraz, diazinon, and lindane are the most active components. Finally, endectocides combine the activity against internal and external parasites, offering greater convenience and a broader spectrum in parasite control, such as lactone macrolides (ivermectin, doramectin, abamectin, etc).

The strategy for controlling parasites in farms must be based on the prevalence of parasites, their epidemiology and farm management (Molento and Almeida, 2004). Just as with other veterinary drugs, antiparasitic substances must be applied following good farming practices (using correct doses of authorized products, and respecting the withdrawal period, among others) to avoid drug residues in products of animal origin such as milk and, therefore, to ensure the consumers' safety (FAO/IDF, 2011). In this sense, it is important to remark that there are only a limited number of antiparasitic products licensed to treat goats during the lactation period. Such products have pharmacologically active substances 
wherefore a Maximum Residue Limit (MRL) in milk (Commission Regulation (EU) No 37/2010) was fixed like albendazol $(M R L=100 \mu \mathrm{g} / \mathrm{kg})$, febendazole $(\mathrm{MRL}=10 \mu \mathrm{g} / \mathrm{kg})$, and diazinon (MRL $=20 \mu \mathrm{g} / \mathrm{kg}$ ) or no MRL needs to be fixed (i.e. diclazuril). However, antiparasitic agents as closantel, levamisole and ivermectin are banned for animals producing milk for human consumption.

On the other hand, the lack of approved parasiticides for use in lactating dairy goats presents a considerable challenge and the use of veterinary products under "cascade" prescription is resulting in mandatory extended milk withholding periods, which may cause difficulties for herds being milked. Thus, the risk of the presence of antiparasitic drug residues in goat milk increases with off-label treatments which may have important health implications (Commision Regulation (EC) No 124/2009; Commision Regulation (EU) No 610/2012).

Monitoring for the presence of veterinary drugs in foodstuffs of animal origin is mandatory in the EU. Following European legislation the screening of antibiotic residues in raw milk should be performed routinely at different stages of the milk production chain (Regulation (EC) No 853/2004 and No 854/2004). For this purpose, microbial inhibitor tests are widely used in control laboratories, as they are economical, easy to use and have a high sample throughput. However, they are non-specific for antibiotics and may be affected by different substances capable of inhibiting the growth of the test microorganism (Geobacillus stearothermophilus var. calidolactis), leading to false positive results when antibiotic-free milk samples are analysed.

The occurrence of false positive outcomes in regulatory milk quality programmes can generate serious consequences for farmers and dairies. Thus, uncontaminated milk could be declared unfit for human consumption and withdrawn although it might not contain antibiotics above the legally established limits. Some authors indicate that the occurrence of false positive results increases with high somatic cell count levels (Kang and Kondo, 2001; Reybroeck and Ooghe, 2012), the presence of natural inhibitors in milk (Halbert et al., 1996; Carlsson et al., 1989), colostrum (Egan and Meaney, 1984; Romero et al., 2014) or elevated concentrations of detergents and disinfectants (Schiffman et al., 1992; Romero et al., 2014) among others factors. In addition, Fabre et al. (1995) observed that the presence of antiparasitic drug residues was the cause of positive results (1\%) on microbial inhibitor tests in milk. Also, Reybroeck (2010) suggested the possible interference of antiparasitic substances on screening tests. 
Therefore, the aim of this work was to evaluate the effect of the presence of antiparasitic substances in goat milk on the microbial test response.

\section{Material and methods}

\subsection{Milk samples and antiparasitic substances}

Raw antimicrobial-free milk from Murciano-Granadina goats in mid-lactation was collected from the Universitat Politècnica de València's (UPV, Valencia, Spain) experimental flock. The animals had not received any antibiotic or antiparasitic treatment during the lactation period to avoid the possible appearance of residues in milk.

Goat milk samples were spiked with seven antiparasitic substances: albendazole (A4673), closantel (34093), diazinon (45428), diclazuril (34057), febendazol (35032), ivermectine (18898) and levamisole (31742), which were supplied by Sigma-Aldrich Química, S.A. (Madrid, Spain).

For use, antiparasitic drugs were dissolved in dimethyl sulphoxide (DMSO), with the exception of the diazinon and diclazuril solutions which were made with ethanol (EtOH). For each antiparasitic substance, eight different concentrations, selected from a pre-experimental work, were analysed in twelve replicates. Drug solutions were prepared on a daily basis and spiked milk samples analysed within four hours of spiking.

\subsection{Milk analysis}

Bulk milk samples from goats were analysed to evaluate their gross composition (fat, protein and total solids) using MilkoScan 6000 (Foss, Hillerød, Denmark), the somatic cell count (SCC) was obtained using Fossomatic 5000 (Foss), and the pH value was measured by a conventional pH meter (Crison, Barcelona, Spain).

Spiked milk samples were analysed simultaneously by three microbial inhibitor tests: BRT MRL (AiM, Analytik in MilchProduktions-und Vertriebs-GmbH, Munich, Germany), Delvotest SP-NT MCS (DSM Food Specialties, Delft, the Netherlands) and Eclipse 100 (ZEULAB S.L., Zaragoza, Spain). Commercial tests were used according to the manufacturer's instructions. A negative control (antimicrobial-free goat milk) and a positive control (antimicrobial-free goat milk spiked with $4 \mu \mathrm{g} / \mathrm{kg}$ of benzylpenicillin) were also included in each microplate test to check their suitability.

Visual interpretation of the test results was carried out independently by three trained technicians assessing the colour change in the test medium; classifying milk samples as 
"positive" when the colour remained purple/blue and "negative" when the colour changed to yellow.

\subsection{Statistical analysis}

A logistic regression model was applied to investigate the effect of the presence of antiparasitic substances in goat milk on the occurrence of false positive outcomes in microbial screening tests. Statgraphics Centurion XVI software (StatPoint Technologies, Inc., Warrenton, VA, USA) was used for statistical analyses.

Variables were analysed using the following logistic model:

$$
L_{i j}=\operatorname{Logit}\left[P_{i}\right]=+\beta_{0}+\beta_{1} C_{i}+\varepsilon_{i j}
$$

Where: $\left[P_{i}\right]=$ probability for a positive response; $\beta_{0}=$ intercept; $\beta_{1}=$ estimate parameter for the model; $\left[C_{i}\right]=$ effect of antiparasitic concentration $(\mathrm{i}=8) ; \varepsilon_{\mathrm{ij}}=$ residual error.

Using the logistic regression equation, the inhibitory concentration of the antiparasitic substance producing 5,10 and $50 \%$ of positive results $\left(\mathrm{IC}_{5}, \mathrm{IC}_{10}, \mathrm{IC}_{50}\right.$, ) in microbial screening tests was calculated.

\section{Results and discussion}

Goat milk samples used in this study as negative milk (antimicrobial-free) showed similar characteristics to those reported by Salama et al. (2007) and Beltrán et al. (2013) for milk from Murciano-Granadina goats. The mean values obtained for the milk quality parameters tested for were: $\mathrm{pH}: 6.71 \pm 0.01$; fat: $5.11 \pm 0.86 \%$, protein: $3.68 \pm 0.38 \%$, dry matter: $14.21 \pm 0.42 \%$, and SCC: $678 \pm 95 \times 10^{3} \mathrm{cell}^{-\mathrm{ml}^{-1}}$.

Table 1 summarizes the frequencies of positive results (false positive rate) of microbial tests when goat milk samples spiked with different parasiticides were analysed.

As shown in Table 1, all the microbial tests were affected by the presence of antiparasitic drugs in milk although the responses were very variable, showing a higher or lesser percentage of false positive results according to the test and drug. 
Table 1. Effect of the concentration of antiparasitic drugs in goat milk on the frequency of positive results in microbial inhibitor tests

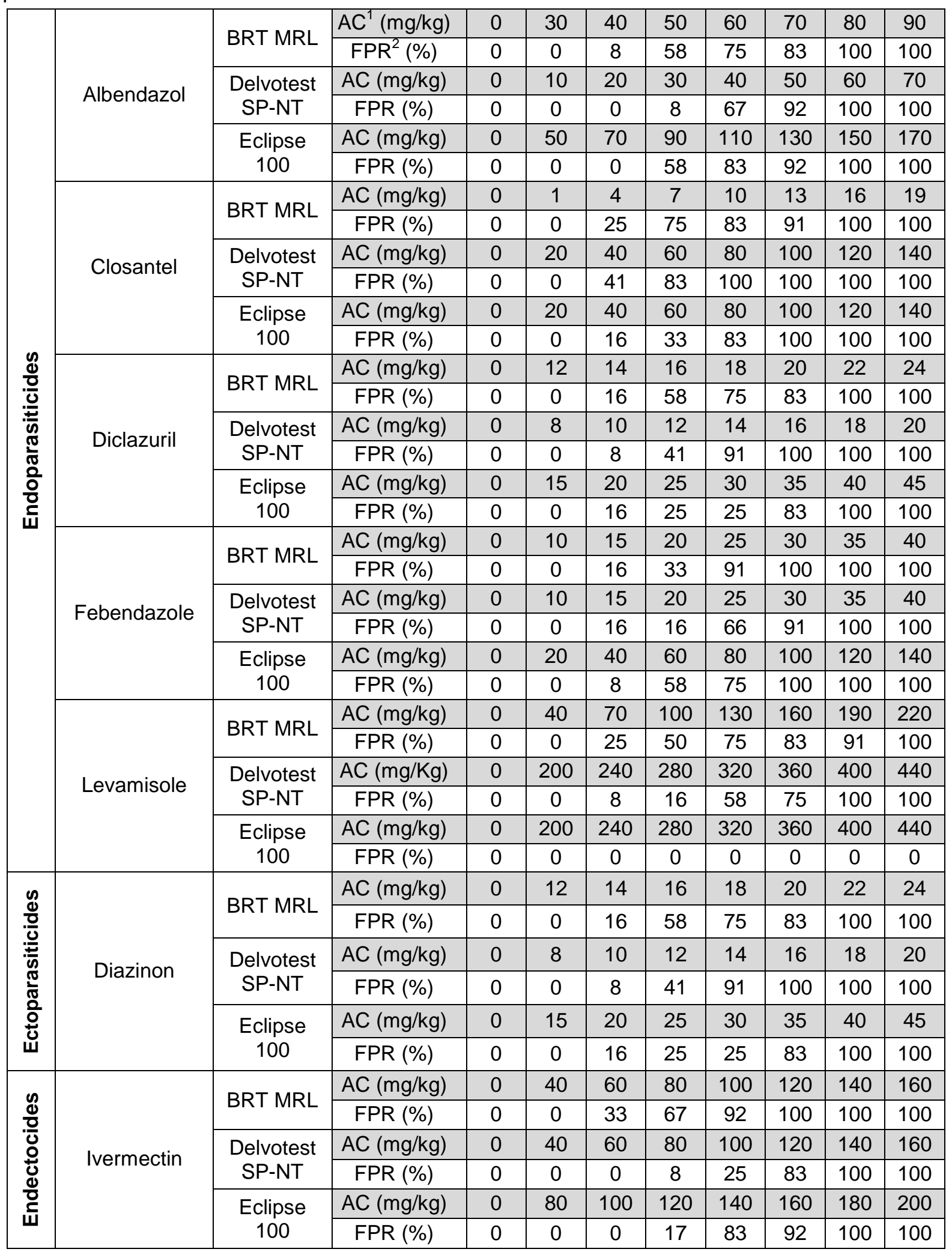

${ }^{1} \mathrm{AC}$ : Antiparasitic drug concentration in milk (mg/kg); ${ }^{2} \mathrm{FPR}$ : Frequency of positive results (\%) 
In general, logistic regression analyses showed that an increase in the antiparasitic drug concentration in milk was associated with an elevation of the predicted likelihood of positive outcomes in all cases, except for the endoparasiticide drug levamisole, which did not interfere in the response of the Eclipse 100 test. The logistic regression equations obtained from the statistical analyses are listed in Table 2.

Table 2. Logistic regression equations to evaluate the effect of the presence of antiparasitic drugs in goat milk

\begin{tabular}{|c|c|c|c|c|c|}
\hline \multirow{2}{*}{$\begin{array}{l}\text { Antiparasitic } \\
\text { substance }\end{array}$} & \multirow{2}{*}{$\begin{array}{c}\text { Microbial } \\
\text { test }\end{array}$} & \multicolumn{2}{|c|}{$\operatorname{Logit}[P]=\beta_{0}+\beta_{1}[$ Antiparasitic $]$} & \multicolumn{2}{|c|}{$\begin{array}{l}\text { Goodness-of- } \\
\text { fittest }\end{array}$} \\
\hline & & $\boldsymbol{\beta}_{0}$ & $\beta_{1}$ & $\mathrm{X}^{2}$ & p-value \\
\hline \multicolumn{6}{|c|}{ Endectoparasiticides } \\
\hline \multirow{3}{*}{ Albendazol } & BRT MRL & -7.701 & 0.000147 & 1.801 & 0.614 \\
\hline & Delvotest SP-NT MCS & -10.158 & 0.000265 & 0.595 & 0.897 \\
\hline & Eclipse 100 & -9.352 & 0.000100 & 1.688 & 0.639 \\
\hline \multirow{3}{*}{ Closantel } & BRT MRL & -3.4214 & 0.000543 & 3.237 & 0.356 \\
\hline & Delvotest SP-NT MCS & -4.8837 & 0.000113 & 0.245 & 0.970 \\
\hline & Eclipse 100 & -5.1513 & 0.000083 & 1.727 & 0.631 \\
\hline \multirow{3}{*}{ Diclazuril } & BRT MRL & -6.995 & 0.000081 & 1.173 & 0.759 \\
\hline & Delvotest SP-NT MCS & -7.755 & 0.000086 & 1.727 & 0.631 \\
\hline & Eclipse 100 & -14.700 & 0.000100 & 1.456 & 0.692 \\
\hline \multirow{3}{*}{ Febendazole } & BRT MRL & -7.626 & 0.000332 & 0.262 & 0.966 \\
\hline & Delvotest SP-NT MCS & -17.934 & 0.000395 & 2.013 & 0.569 \\
\hline & Eclipse 100 & -6.385 & 0.000100 & 0.518 & 0.914 \\
\hline \multirow{3}{*}{ Levamisole } & BRT MRL & -4.097 & 0.000038 & 2.619 & 0.454 \\
\hline & Delvotest SP-NT MCS & -14.384 & 0.000137 & 1.445 & 0.694 \\
\hline & Eclipse 100 & - & - & - & - \\
\hline \multicolumn{6}{|c|}{ Ectoparasiticides } \\
\hline \multirow{3}{*}{ Diazinon } & BRT MRL & -15.5740 & 0.000984 & 1.094 & 0.778 \\
\hline & Delvotest SP-NT MCS & -18.378 & 0.001297 & 0.161 & 0.983 \\
\hline & Eclipse 100 & -6.932 & 0.000201 & 4.466 & 0.215 \\
\hline \multicolumn{6}{|l|}{ Endectocides } \\
\hline \multirow{3}{*}{ Ivermectin } & BRT MRL & -6.983 & 0.000098 & 0.893 & 0.826 \\
\hline & Delvotest SP-NT MCS & -14.384 & 0.000137 & 1.445 & 0.694 \\
\hline & Eclipse 100 & -16.906 & 0.000128 & 0.314 & 0.957 \\
\hline
\end{tabular}

Logit[P]: Ln (Probability (+)/1-Probability (+)); [Antiparasitic]: Antiparasitic drug concentration in goat milk 
To compare the effect of the different parasiticides in goat milk on the performance of microbial screening tests, the inhibitory concentrations of parasiticides producing 5,10 and $50 \%$ of positive results $\left(\mathrm{IC}_{5}, \mathrm{IC}_{10}\right.$ and $\left.\mathrm{IC}_{50}\right)$ were calculated from the logistic regression equations (Table 3).

As shown in Table 3, for the Eclipse 100 test the highest concentrations of parasiticides were needed before an inhibitory effect was noted. On the contrary, the BRT MRL test was faster affected, presenting interferences due to lower concentrations of antiparasitic agents in the milk. The higher sensitivity of the BRT MRL test compared to the other microbial tests could be related to the different system used to express the inhibition of the Geobacillus stearothermophilus var. calidolacıs metabolism. Eclipse 100 and Delvotest SP-NT MCS use bromocresol purple as a pH indicator while the BRT MRL test uses black brilliant as a redox indicator. In this sense, it should be noted that antiparasitic drugs are considered by some authors as redox-active (Pal and Bandyopadhyay, 2012; Perbandt et al., 2014) due to their ability to inhibit vital redox reactions or promote oxidative stress in parasites.

Table 3. Inhibitory concentrations $(\mathrm{mg} / \mathrm{kg}$ ) of antiparasitic substances in goat milk producing 5,10 and $50 \%$ false-positive results $\left(\mathrm{IC}_{5}, \mathrm{IC}_{10}, \mathrm{IC}_{50}\right)$ on microbial inhibitor tests

\begin{tabular}{|c|c|c|c|c|c|c|c|c|c|}
\hline \multirow{2}{*}{ Antiparasitic drug } & \multicolumn{3}{|c|}{ BRT MRL } & \multicolumn{3}{|c|}{ Delvotest SP-NT MCS } & \multicolumn{3}{|c|}{ Eclipse 100} \\
\hline & $\mathrm{IC}_{5}$ & $\mathrm{IC}_{10}$ & $I_{50}$ & $\mathrm{IC}_{5}$ & $\mathrm{IC}_{10}$ & $\mathrm{IC}_{50}$ & $\mathrm{IC}_{5}$ & $\mathrm{IC}_{10}$ & $\mathrm{IC}_{50}$ \\
\hline \multicolumn{10}{|l|}{ Endoparasiticides } \\
\hline Albendazole & 32 & 37 & 52 & 27 & 30 & 38 & 64 & 71 & 93 \\
\hline Closantel & 1 & 2 & 6 & 17 & 24 & 43 & 26 & 35 & 62 \\
\hline Diclazuril & 50 & 59 & 87 & 53 & 62 & 88 & 117 & 124 & 147 \\
\hline Febendazole & 14 & 16 & 23 & 38 & 51 & 45 & 34 & 42 & 63 \\
\hline Levamisole & 30 & 50 & 107 & 240 & 260 & 317 & - & - & - \\
\hline \multicolumn{10}{|l|}{ Ectoparasiticides } \\
\hline Diazinon & 13 & 14 & 16 & 12 & 12 & 14 & 20 & 24 & 34 \\
\hline \multicolumn{10}{|l|}{ Endectocides } \\
\hline Ivermectin & 41 & 49 & 71 & 83 & 89 & 105 & 109 & 115 & 132 \\
\hline
\end{tabular}


Regarding the parasicitide substances investigated, closantel, is the endoparasiticide that produced higher interference (positive results) in all microbial tests, especially in the BRT MRL test. On the contrary, higher concentrations of levamisole were required to produce positive results in microbial screening tests. No false positive results were obtained for this substance in the Eclipse 100 test.

The ectoparasiticide diazinon was causing interference at relatively lower concentrations while the endectocide ivermectin showed an inhibitory action only from higher concentrations, especially for the Eclipse 100.

The depletion of some parasiticides such as albendazol, febendazol or ivermectin has been evaluated by some authors using HPLC techniques in milk from goats. In general, the residual amounts of antiparasitic drugs resulting from the application of veterinary treatment are much lower than the inhibitory concentrations calculated in this study (Waldhalm et al., 1989; Scott el al., 1990; Cinquina et al., 1997), except for the antiparasitic, closantel, that, according to Lezzi et al. (2014), could be found in goat milk at a concentration much closer to the inhibitory concentrations estimated here for the BRT MRL test $(0.8 \pm 0.3 \mu \mathrm{g} / \mathrm{ml})$.

However, the depletion of some antiparasitic substances in goat milk is unknown, especially when veterinary drugs are applied as off-label treatments for which no registration documents with depletion data in goats are available. Another aspect that could also affect the performance of microbiological tests is the metabolism of these substances in the animal organism, producing different metabolites that could present a greater ability to interfere with the growth of the test microorganism than the pattern drugs used in this study. In addition, the characteristics of the milk from dairy goats infested with parasites could be affected as a consequence of the immune response of the animals and this should also be considered. Therefore, carrying out in vivo studies using infested animals treated with different antiparasitic substances would be desirable to be able to determine the effect of these substances on the microbial screening test response as well as to determine the residual levels of these drugs in milk resulting from authorized and unauthorized treatments that can be carried out in dairy farms.

\section{Conclusions}

Microbial inhibitor tests for screening antibiotics can be affected by concentrations of antiparasitic drugs in goat milk higher than those indicated in the parasiticide depletion studies, suggesting that antiparasitic treatments are not related to false positive outcomes in microbial screening tests. 
In practice, antiparasitic substances are often applied in off-label treatments due to the limited availability of authorized products for dairy goats in lactation, increasing the risk of incidence of residues of these substances or their metabolites in milk. Taking in account this aspect, together with the possibility of interference of the microbial inhibitor test by potential alterations of the milk properties from infested animals, the performance of in vivo studies would be convenient.

\section{Acknowledgements}

This work is part of the AGL-2009-11524 funded by the Ministry of Science and Innovation (Madrid, Spain) and the Generalitat Valenciana (ACOMOP/2012/164, Valencia, Spain). The authors are grateful to AiM Analytik in MilchProduktions-und Vertriebs-GmbH (Munich, Germany), DSM Food Specialties (Delft, the Netherlands) and ZEULAB S.L. (Zaragoza, Spain) for their support.

\section{References}

Beltrán, M.C., Romero, T., Althaus, R.L., Molina, M.P. 2013. Evaluation of the Charm maximum residue limit $\beta$-lactam and tetracycline test for the detection of antibiotics in ewe and goat milk. J.Dairy Sci. 96: 2737-2745.

Carlsson, A., Björck L., Persson, K. 1989. Lactoferrin and lysozyme in milk during acute mastitis and their inhibitory effect in Delvotest P. J. Dairy Sci. 72: 3166-3175.

Cinquina, A., Longo, F., Raponi, A., Bocsa, A., Cozani, R. 1997. Pharmacokinetic albendazole metabolites in goat milk and milk products. Ital. J. Food Sci. 9: 231-237.

Commission Regulation (EC) No 124/2009 of 10 February 2009 setting maximum levels for the presence of coccidiostats or histomonostats in food resulting from the unavoidable carry-over of these substances in non-target feed. Off. J.Eur. Comm 2010 L40: 7-11.

Commission Regulation (EU) No 37/2010 of 22 December 2009 on pharmacologically active substances and their classification regarding maximum residue limits in foodstuffs of animal origin. Off. J.Eur. Union 2010 L15: 1-72.

Commission Regulation (EU) No 610/2012 of 9 July 2012 amending Regulation (EC) No 124/2009 of 10 February 2009 setting maximum levels for the presence of coccidiostats or histomonostats in food resulting from the unavoidable carry-over of these substances in non-target feed. Off. J.Eur. Comm 2012 L78: 1-3.

Egan, J., Meaney, W.J. 1984. The inhibitory effect of mastitic milk and colostrum on test methods used for antibiotic detection. Ir. J. Food Sci. 39: 774-775. 
Fabre, J.M., Moretain, J.P., Ascher, F., Brouillet, O., Berthelot, X. 1995. Main causes of inhibitors in milk. A survey in one thousand French dairy farms. In: Residues of Antimicrobial Drugs and other Inhibitors in Milk. IDF S.I. 9505: 27-31. International Dairy Federation, Brussels, Belgium.

FAO/IDF, 2011. Guide to good dairy farming practice. Animal Production and Health Guidelines. № 8, FAO, Rome, Italy.

Fthenakis, G. C., Papadopulos, E., Himonas, C., Leontide, L., Kritas, S., Papatsas, J. 2000. Efficacy of moxidectin against sarcoptic mange and effects on milk yield of ewes and growth of lambs. Vet. Parasitol. 87: 207-216.

Halbert, R.W., Erskine, R.J. Bartlett, P.C., Johnson, G.L. 1996. Incidence of false-positive results for assays used to detect antibiotics in milk. J. Food Prot. 45: 571-573.

Hoste, H., Chartier, C. 1998. Response to challenge infection with Haemonchus contortus and Trichostrongylus colubriformis in dairy goats. Consequences on milk production. Vet. Parasitol. 74: 43-54.

Lezzi, S., Lifschitz, A., Sallovitz, J., Nejamkin, P., Lloberas, M., Manazza, J. 2014. Closantel plasma and milk disposition in dairy goats: assessment of drug residues in cheese and ricotta. J. Vet. Pharmacol. Therap. http://onlinelibrary.wiley.com/doi/10.1111/jvp.12135/pdf

Kang, J.T.H., Kondo, F. 2001. Occurrence of false-positive results of inhibitor on milk samples using the Delvotest SP assay. J. Food Prot. 64: 1211-1215.

Molento, M.B., Almeida, L. 2004. Prácticas de controle parasitário adotadas por criadores de ovinos e caprinos. pp 241. In: Congresso brasileiro de parasitologia veterinaria XII, Ouro Preto, Brazil.

Morgan, E., Wall, R. 2009. Climate change and parasitic disease: farmer mitigation?. Trends Parasitol. 25: 308-131.

Pal, C., Bandyopadhyay, U. 2012. Redox-active antiparasitic drugs. Antioxid. Redox Signal. 17: 555-582.

Perbandt, M., Ndjonka, D., Liebau, E. 2014. Protective mechanisms of hemintics against reactive oxygen species are highly promising drug targets. Curr. Med. Chem. 21: 17941808.

Plant, J.W., Cristopher, J.L. 2011. Treatment and control of ectoparasites in sheep. Food Animal Prac. 27: 203-212. 
Regulation (EC) No 853/2004 of the European Parliament and of the Council of 29 April 2004 laying down specific hygiene rules for on the hygiene of foodstuffs. Off. J. Eur. Comm 2004 L139: 55-205.

Regulation (EC) No 854/2004 of the European Parliament and of the Council of 29 April 2004 laying down specific hygiene rules for the organisation of official controls on products of animal origin intended for human consumption. Off. J. Eur. Comm 2004 L139: 206-320.

Reybroeck, W. 2010. Screening for residues of antibiotics and chemotherapeutics in milk and honey. PhD Thesis. pp 295. Faculty of Veterinary Medicine, Ghent University, Belgium.

Reybroeck, W., Ooghe, S. 2012. FASFC acceptance criteria for microbiological inhibitor tests: fulfillment by new tests. pp 197-201. In: Schilt R, editor. Proceedings of the EuroResidue VII Conference on residues of veterinary drugs in food, Egmond aan Zee, The Netherlands, May 14-16.

Romero, T., Beltrán, M.C., Althaus, R.L., Molina, M.P. 2014. Detection of antibiotics in goats' milk: Effect of detergents on the response of microbial inhibitor tests. J. Dairy Res. 81: 372-377.

Romero, T., Beltrán, M.C., Pérez-Baena, I., Rodríguez, M., Molina, M.P. 2014. Effect of the presence of colostrum on microbial screening methods for antibiotic detection in goats' milk. Small Rumin. Res. 121: 376-381.

Salama, A.A.K., Such, X., Caja, G., Rovai, M., Casals, R., Albanell, E., Marín, M.P., Martí, A. 2003. Effects of once versus twice daily milking throughout lactation on milk yield and milk composition in dairy goats. J. Dairy Sci. 86: 1673-1680.

Schiffmann, A.P., Schütz, M., Wiesner, H.U. 1992. False negative and positive results in testing for inhibitory substances in milk. II. Factors influencing the brilliant black reduction test (BRT). Milchwissenschaft. 47: 770-772.

Scott, E.W., Kinabo, L.D., McKellar, Q.A. 1990. Pharmacokinetics of ivermectina after oral or percutaneous administration to adult milking goats. J. Vet. Pharmacol. Ther. 13: 432-435.

Waldhalm, S.J., Criss, E.A., Neff-Davis, C.A., Huber, W.G. 1989. Febendazole clearance from goat milk. Small Rumin. Res. 2: 79-84.

Walton, S.F., Currie, B.J. 2007. Problems in diagnosing scabies, a global disease in human and animal population. Clin. Microbiol. Rev. 20: 268-279. 


\title{
Albendazole residues in goat milk. Interferences on microbial inhibitor tests
}

\begin{abstract}
Albendazole is currently used in strategic control schemes for gastrointestinal nematodes in domestic livestock. However, there are hardly any drugs licensed to treat these parasites in dairy goats and, therefore, albendazole is usually applied under 'cascade' upon veterinary prescription. The aim of this work was to evaluate the presence of this anthelmintic and its metabolites in milk after oral treatment in dairy goats, as well as to investigate the potential effect of the residues on the response of microbial inhibitor tests used for screening for antibiotic residues in raw milk. Eighteen healthy Murciano-Granadina goats in mid-lactation were treated with a single oral administration of commercially available albendazole registered for dairy sheep $\left(\operatorname{Ovidax}^{\circledR}\right.$ ), corresponding to a dose of $7.5 \mathrm{mg} / \mathrm{kg} \mathrm{b.w.} \mathrm{of} \mathrm{active}$ compound. Over a seven day period after antiparasitic treatment, the goats were milked once a day and the milk samples were collected individually. The quantification of albendazole and their metabolites was performed by HPLC and milk samples were also analysed by microbial inhibitor tests (BRT MRL, Delvotest SP-NT MCS and Eclipse 100). Due to its rapid oxidation, the albendazole parent drug was not detected in any experimental sample. The maximum concentration of its metabolites ( $\mathrm{ABZSO}, \mathrm{ABZSO} \mathrm{O}_{2}$ and $\mathrm{NH}_{2}-\mathrm{ABZSO}_{2}$ ) was observed on the first day post-treatment and from the third day, the sum of all metabolites was lower than the MRL established for albendazole $(100 \mu \mathrm{g} / \mathrm{kg}$ for the sum of albendazole sulphoxide, albendazole sulphone, and albendazole 2-amino sulphone, expressed as albendazole) by European legislation (Regulation 37/2010). Therefore, this veterinary product could be applied under cascade in dairy goats following the manufacturer's recommendations for sheep without risk for the consumer's safety. Regarding the effect of antiparasitic treatment on the microbial test response, only one positive result in the first day post-treatment was found for the Delvotest SP-NT MCS and Eclipse 100 tests. However, a high occurrence of positive results were obtained for the BRT MRL test during the six days after albendazole administration, even when albendazole metabolites were not detected in milk, suggesting that other factors related to the albendazole application other than drug concentration are able to affect the microbial test response in some cases.
\end{abstract}

Key words: goat milk, albendazole, false positive results, microbial tests 


\section{Introduction}

Gastrointestinal nematodes remain one of the main constraints on ruminant production, since they can cause a reduction in skeletal growth, live-weight gain and milk yield (Waller, 1997; Houtert and Sykes, 2010). In particular, goats can be more heavily infested than sheep, and both the acquisition and expression of immune responses against gastrointestinal nematodes are less efficient in goats than in sheep (Hoste et al., 2010). Furthermore, the control of gastrointestinal nematode infestations in goats is still largely based on the use of anthelminthic products at regular intervals and is currently made more complicated by the presence of resistant nematodes to one or more types of veterinary drugs (Zanzani et al., 2014).

The main group of anthelmintics used for the prevention and control of gastrointestinal nematodes in domestic animals is the group of benzimidazoles, derived from the simple benzimidazole nucleus and which includes the thiabendazole analogues and the benzimidazoles carbamate (Botsoglou and Fletouris, 2001). Thus, some authors indicate that farmers essentially use benzimidazoles (> 80\%) in the control treatments for goat herds (Hoste et al., 2000; Zanzani et al., 2014), at a rate of nearly three treatments per year, except in organic farms (Hoste et al., 2000). Among benzimidazole drugs, the most widely used in farms are albendazole, febendazole, oxfebendazole and thiabendazole (Su et al., 2003).

Albendazole is effective for the prevention and control of gastrointestinal nematodes, including migrating larval stages and lungworms (Campbell, 1990). Moreover, it is readily absorbed by the gut, and following this absorption, albendazole is metabolised (Danaher et al., 2007) by rapid pass oxidation of its sulphide group to form albendazole sulphoxide (ABZSO), with further oxidation to form albendazole sulphone $\left(\mathrm{ABZSO}_{2}\right)$ and deacetylation of the carbamate group to form albendazole 2-aminosulphone $\left(\mathrm{NH}_{2}-\mathrm{ABZSO}_{2}\right)$. Due their embryotoxicity and teratogenicity in a variety of animal species (Teruel et al., 2003; Moreti et al., 2005), their residue levels require carefully monitoring in animal products. Maximum residue limit (MRL) for albendazole and its metabolites has been established in $100 \mu \mathrm{g} / \mathrm{kg}$ for milk of all ruminants for the sum of albendazole sulphoxide, albendazole sulphone, and albendazole 2-amino sulphone, expressed as albendazole, by the European legislation (Commission Regulation (EU) No 37/2010).

It is important to note that the control of parasitic infestation in goats has limitations since only a reduced number of antiparasitic drugs are authorized for their use in dairy goats and, therefore, anthelmintics licensed for sheep are generally used under 'cascade' in the 
treatment of goats. However, it has been shown that the physiology of goats and their metabolism of drugs differ somewhat from those of sheep. As a result, the applicable drug dose rates or withdrawal periods established by manufactures in sheep cannot necessarily be translated directly to goats. Consequently, the application of these veterinary products under 'cascade' in lactating goats could suppose a risk for consumer's safety due to the possible presence of antiparasitic drug residues in the milk supply.

To guarantee public health related with the presence of veterinary drug residues in milk, numerous controls to screen antimicrobial substances are carried out at the different phases of the goat milk chain production (Regulation (EC) No 853/2004). Several commercial tests for screening antimicrobials in milk are available. Microbial inhibitor tests are widely used in control laboratories, as they are easy to perform, their cost is low and they have a broad spectrum detection capability. However, veterinary drugs other than antimicrobial substances might cause interferences in these screening tests. In this sense, Fabre et al. (1995), in a study carried out on dairy cow farms, found that $1 \%$ positive results in microbial inhibitor tests were associated with antiparasitic treatments. Thus, the presence of the antiparasitic drugs could cause non-compliant results (false positive results) in antibiotic-free milk samples, and generate serious consequences for farmers and the dairy industry.

The aim of this study was to evaluate the presence of residues of albendazole and its metabolites in goat milk, as well as to estimate their effect on the microbial screening tests response.

\section{Material and methods}

\subsection{Animals, albendazole treatment and milk sampling}

Animal procedures and management protocols were approved by the Ethics Committee of Universitat Politècnica de València (UPV, Valencia, Spain). The study was carried out using eighteen healthy lactating Murciano-Granadina goats in mid-lactation from the experimental farm of the Institute of Animal Science and Technology of UPV. The animals were in good health and had not received any veterinary treatment before the experimental period began.

Three days before applying the treatment with Ovidax ${ }^{\circledR}$ (albendazole or ABZ), a preexperiment was performed to verify that the milk samples obtained daily from each animal had negative results in all the microbial inhibitor tests. 
Due to the limited number of available commercial antiparasitic drugs for goats, the animals were treated under 'cascade' with a single oral dose of a commercial ovine formulation of $2.5 \%$ of albendazole frequently used in goats in Spain (Ovidax ${ }^{\circledR}$, Fatro Ibérica S.L., Barcelona, Spain). The anthelmintic dose $(18 \mathrm{ml})$ was calculated according to the body weight $(55-60 \mathrm{~kg})$ and the manufacturer's indications for ovine species $(2-3 \mathrm{ml} / 10 \mathrm{~kg}$ of body weight, corresponding to a dose of $7.5 \mathrm{mg} / \mathrm{kg}$ b.w. of active compound). Administration was carried out with an automatic syringe (NJ Phillips $20 \mathrm{ml}$, Somersby, Australia), stirring the product and depositing it directly on the tongue of the animal. The withdrawal period of Ovidax ${ }^{\circledR}$ specified by the manufacturer is 4 days for sheep milk.

After treatment with albendazole, the animals were milked once a day (08:00 hours) in a milking parlour (high line; CASSE $2 \times 12 \times 6$, Alfa Laval, Lund, Sweden) and the sampling was carried out along a seven-day period. From each milking, the milk samples were collected from each goat individually and the analyses by microbial inhibitor tests were carried out in triplicate during the four-hour period after milk collection. Three aliquots of milk were frozen $\left(-80^{\circ} \mathrm{C}\right)$ until HPLC quantification for albendazole and its metabolites.

\subsection{Analytical methods}

\section{Albendazole and metabolite quantification}

Extraction procedures, standards, and chromatographic conditions to quantify albendazole (ABZ) and its metabolites (albendazole sulphoxide, ABZSO; albendazole sulphone, $\mathrm{ABZSO}_{2}$, and 2-aminosulphone, $\mathrm{NH}_{2}-\mathrm{ABZSO}_{2}$ ) were carried out to the protocol established by Moreno et al. (2005) with some minor modifications detailed below. The standards of $\mathrm{ABZ}$ (A4673), $\mathrm{ABZSO}$ (35395), $\mathrm{ABZSO}_{2}$ (35394), $\mathrm{NH}_{2}-\mathrm{ABZSO}_{2}$ (32181) were provided by Sigma-Aldrich (Sigma-Aldrich Química, S.A., Madrid, Spain) and the stock and working solutions were prepared in methanol (HPLC-grade, J.T.Baker, Deventer, the Netherlands).

Sep-Pak vac 1cc C18 cartridges (Waters Corporation, Milford, MA) previously conditioned with $1 \mathrm{ml}$ of methanol, followed by $1 \mathrm{ml}$ of water were used. Fifty microliters of each milk sample were analysed using a Waters HPLC system (Waters Corporation) consisting of two pumps (Mod. 515, Waters), an autosampler (Mod. 717 plus, Waters), an ultraviolet visible detector (Mod. 2489 Waters). A reversed-phase SunFire C18 column (Waters, $4.6 \times 150 \mathrm{~mm}, 5 \mu \mathrm{m}$ ) was used for separation at a constant temperature of $35^{\circ} \mathrm{C}$ with a flow rate of $1 \mathrm{ml} / \mathrm{min}$ using acetonitrile and ammonium acetate buffer $(0.025 \mathrm{M}, \mathrm{pH} 5)$ as the mobile phase. The detection of drugs/metabolites was carried out at a wavelength of $290 \mathrm{~nm}$. 
The identification and quantification of the $\mathrm{ABZ}, \mathrm{ABZSO}, \mathrm{ABZSO}$, and $\mathrm{NH}_{2}-\mathrm{ABZSO}_{2}$ in milk samples was performed via an external standard method. The CC $\beta$ or detection limit and CC $\alpha$ or quantification limit were calculated according to Prieto et al. (2003). The CC $\beta$ values obtained for the different compounds analysed were $7.9,5.1,11.0$, and $1.0 \mu \mathrm{g} / \mathrm{kg}$, respectively, while the CCa values were 19.6, 7.7, 26.0, and $2.4 \mu \mathrm{g} / \mathrm{kg}$, respectively. Drug recovery was estimated by comparison of the peak area from spiked milk samples at different concentrations with the peak area resulting from direct injections of $A B Z$ and metabolite standards in methanol. Recovery of $A B Z /$ metabolites in milk ranged between 80 and $98 \%$.

\section{Microbial inhibitor tests}

The milk samples were analysed by Brilliant Black Reduction Test MRL (BRT MRL. AiM, Analytik in MilchProduktions-und Vertriebs-GmbH, Munich, Germany), Delvotest SP-NT MCS (DSM Food Specialties, Delft, the Netherlands) and Eclipse 100 (ZEULAB S.L., Zaragoza, Spain). Negative (antimicrobial-free goat milk) and positive (antimicrobial-free goat milk spiked with $4 \mu \mathrm{g} / \mathrm{kg}$ of benzylpenicillin) controls were included on each plate. The tests were used according to each manufacturer instructions and the indicator colour changes were assayed by visual interpretation, classifying milk samples as "positive" when the colour remained purple/blue and "negative" when the colour was changed to yellow.

\subsection{Statistical analysis}

The non-parametric Kruskal-Wallis test (K-W) was used to analyse statistical differences $(p<0.05)$ between the ABZ concentration and its metabolites with respect to days post-treatment. The Bonferroni test was performed to establish the differences between the days post-treatment, and the levels of significance $(p<0.05)$ were determined. Statgraphics Centurion XVI software (16.1.03) (StatPoint Technologies, Inc., Warrenton, VA, USA) was used for statistical analyses.

\section{Results and Discussion}

All milk samples obtained during the first week after oral albendazole administration were analysed using the HPLC technique to determine the concentration of parent drug and its metabolites in goat milk. Table 1 shows the concentration range corresponding to the elimination of albendazole and its metabolites during the first seven days post-treatment.

The results indicate that the parent compound, albendazole, was not detected in any sample of the experiment, confirming its rapid oxidation. This fact has also been noted by other authors in sheep (De Liguoro et al., 1996), goat (Cinquina et al., 1997) and cow milk 
(Moreno et al., 2005). The maximum concentration of $\mathrm{ABZSO}, \mathrm{ABZSO}_{2}$ and $\mathrm{NH}_{2}-\mathrm{ABZSO}_{2}$ obtained in this study was observed on the first day post-treatment, and then decreased until the fourth day. From the third day, the sum of all metabolites was lower than the MRL established for albendazole $(100 \mu \mathrm{g} / \mathrm{kg}$ for the sum of albendazole sulphoxide, albendazole sulphone, and albendazole 2-amino sulphone, expressed as albendazole; Commission Regulation (EU) No 37/2010). Thus, the withdrawal period of 4 days established for sheep could be applied to dairy goats, ensuring the milk safety.

Table 1. Albendazole and albendazole metabolite residues in goat milk during the first seven days post-treatment

\section{Residues of albendazole metabolites $(\mu \mathrm{g} / \mathrm{kg})$}

Compound

Days post-treatment

\begin{tabular}{cccccccc}
\cline { 2 - 4 } & $\mathbf{1}$ & $\mathbf{2}$ & $\mathbf{3}$ & $\mathbf{4}$ & $\mathbf{5}$ & $\mathbf{6}$ & $\mathbf{7}$ \\
\hline $\mathrm{ABZSO}^{2}$ & $\mathrm{ND}$ & $\mathrm{ND}$ & $\mathrm{ND}$ & $\mathrm{ND}$ & $\mathrm{ND}$ & $\mathrm{ND}$ & $\mathrm{ND}$ \\
$\mathrm{ABZSO}_{2}{ }^{3}$ & $37-248$ & $20-130$ & $\mathrm{ND}-42$ & $\mathrm{ND}-30$ & $\mathrm{ND}$ & $\mathrm{ND}$ & $\mathrm{ND}$ \\
$\mathrm{NH}_{2}-\mathrm{ABZSO}_{2}{ }^{4}$ & $82-251$ & $15-24$ & $14-31$ & $\mathrm{ND}-20$ & $\mathrm{ND}$ & $\mathrm{ND}$ & $\mathrm{ND}$ \\
$\Sigma$ Metabolites $^{5}$ & $224-1,164$ & $51-201$ & $22-82$ & $\mathrm{ND}-58$ & $\mathrm{ND}$ & $\mathrm{ND}$ & $\mathrm{ND}$ \\
\hline
\end{tabular}

$A B Z^{1}$ : albendazole; $A B Z S O^{2}$ : albendazole sulphoxide; $\mathrm{ABZSO}_{2}{ }^{3}$ albendazole sulphone; $\mathrm{NH}_{2}-\mathrm{ABZSO}_{2}{ }^{4}$ : 2-aminosulphone; $\Sigma$ Metabolites $^{5}$ : sum of all metabolites; ND: non detectable

The non-parametric Kruskal-Wallis test applied to the first 4 days of this study showed significant differences for the effect of time post-treatment on the concentrations in the milk of ABZSO (KW: 47.77, p <0.001), $\mathrm{ABZSO}_{2}\left(\mathrm{KW}: 41.70, \mathrm{p}<0.001\right.$ ), and $\mathrm{NH}_{2}-\mathrm{ABZSO}_{2}$ (KW: $55.15, p<0.001$ ) and the sum of its metabolites (KW 34.28, p <0.001). In Figure 1, which shows the box and whisker plots of concentration of albendazole metabolites at different days post-treatment, it can be observed that the mean concentrations of each of the metabolites were higher for the first day post-treatment than the other days. Significant differences $(p<0.05)$ were found from the analysis of Bonferroni inequality test. 

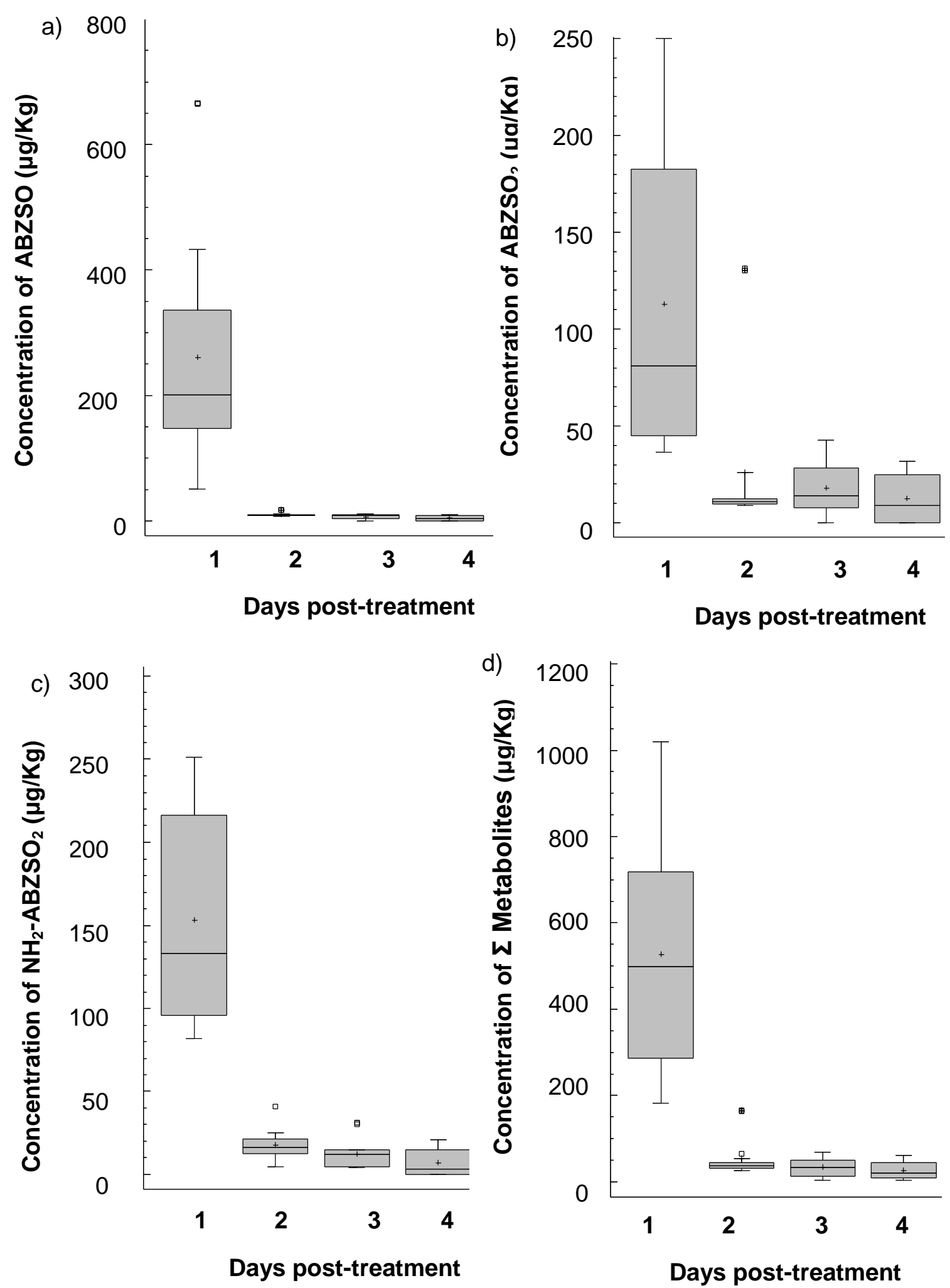

Figure 1. Box and whisker plots illustrating the concentration of the albendazole metabolites in goat milk at different days post-treatment. The plots show the 25th and 75th percentiles (box), median (-), mean (+), 10th and 90th percentiles (whisker bars) and outliers $(\square)$ 
Cinquina et al. (1997), in milk from Saanen goats treated with a single oral administration of albendazole at a dose of $3.75 \mathrm{mg} / \mathrm{kg} \mathrm{b.w.} \mathrm{of} \mathrm{active} \mathrm{compound,} \mathrm{observed}$ residues of $1,100 \mu \mathrm{g} / \mathrm{kg}$ for $\mathrm{ABZSO}, 480 \mu \mathrm{g} / \mathrm{kg}$ for $\mathrm{ABZSO}_{2}$ and $29 \mu \mathrm{g} / \mathrm{kg}$ for $\mathrm{NH}_{2}-\mathrm{ABZSO}_{2}$ at 24 hours. After 48 hours of treatment, the concentrations of $\mathrm{ABZSO}$ and $\mathrm{ABZSO}_{2}$ decreased (25 and $43 \mu \mathrm{g} / \mathrm{kg}$; respectively) while the $\mathrm{NH}_{2}-\mathrm{ABZSO}_{2}$ increased to $54 \mu \mathrm{g} / \mathrm{kg}$. From the third day, no marker residues of albendazole could be detected. The albendazole metabolite concentrations reported by these authors were higher than those observed in the milk from Murciano-Granadina goats. Moreover these authors observed a shorter elimination period than the one found in the current study (2 days vs 4 days, respectively). The differences found could be related to the albendazole dose employed, which was 2 times lower than the one administered in this study (3.75 mg/kg vs $7.5 \mathrm{mg} / \mathrm{kg}$ b.w, respectively).

In sheep milk after an oral dose of $12.5 \mathrm{mg} / \mathrm{kg}$ b.w., De Liguoro et al. (1996) reported that the concentration of $\mathrm{ABZSO}$ and $\mathrm{ABZSO}_{2}$ at 12 hours post-treatment was 3,896 and 902 $\mu \mathrm{g} / \mathrm{kg}$, respectively, decreasing to 62 and $106 \mu \mathrm{g} / \mathrm{kg}$, respectively (48 hours). The only metabolite found at 36 hours post-administration was $\mathrm{NH}_{2}-\mathrm{ABZSO}_{2}(89 \mu \mathrm{g} / \mathrm{kg})$, and from the third day on, no marker residues of albendazole in milk were detected. These concentrations were higher for both metabolites on the first and the second day post-treatment compared with those obtained in the current study. The albendazole dose applied to sheep was higher than the dose administered to goats in this study $(12.5 \mathrm{mg} / \mathrm{kg} v s 7.5 \mathrm{mg} / \mathrm{kg} \mathrm{b.w}$, respectively), which could explain the highest amounts of residues found in sheep milk. Moreover, sheep milk has a higher fat content than goat milk (Park et al., 2007) and, therefore, as albendazole is a lipophilic anthelmintic drug (Kumar et al., 2007), milk from treated sheep could contain greater albendazole residue amounts.

Regarding the effect of antiparasitic drug residues after albendazole treatment on the microbial tests for screening antibiotics in goat milk, only one positive result was obtained for Delvotest SP-NT MCS and Eclipse 100 tests on the first day after treatment. Conversely, when milk samples were analysed by the BRT MRL test, 18 positive results were obtained during the six days post-treatment (Figure 2). The different response of the BRT MRL test with respect to the other two microbial inhibitor tests could be related to differences with regards the indicator systems used (BRT MRL test uses brilliant black as a redox indicator $v s$ bromocresol purple is used as pH indicator in the Delvotest SP-NT MCS and Eclipse 100 tests), culture medium (BRT MRL: Mueller Hinton; Delvotest SP-NT MCS and Eclipse 100: Plate Count Agar (PCA)) and other test characteristics ( $\mathrm{pH}$, spores concentration, etc.), giving different sensitivities for these substances. 


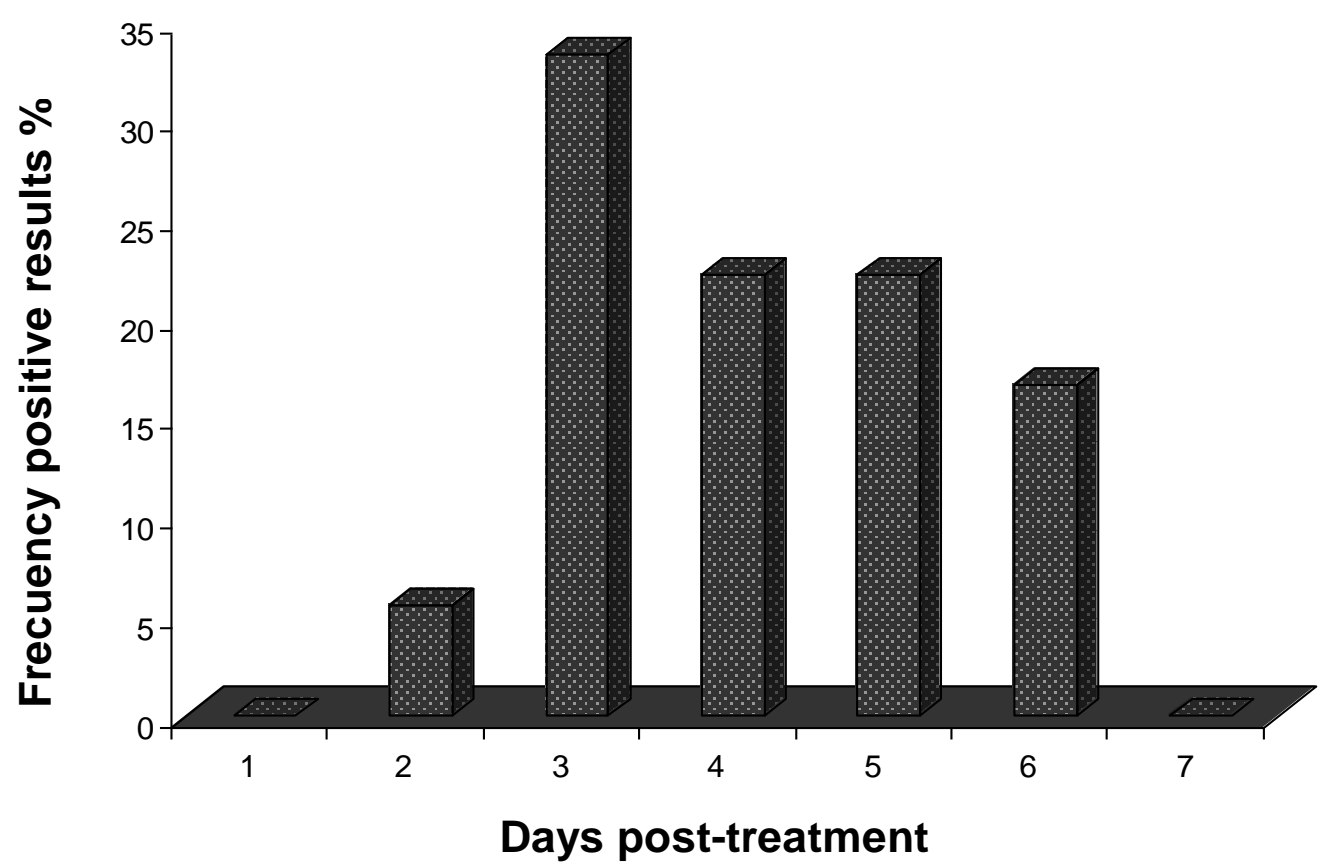

Figure 2. Frequency of positive results in the BRT MRL test in goat milk samples during the first week after treatment of the goats with albendazole

As shown in Figure 2, the highest frequency of positive outcomes (33.0\%) was reached on the third day post-treatment when the albendazole metabolites showed lower concentrations in milk. However, 5 and 6 days after the administration of albendazole, a high number of positive results were observed (22.2 and 17.0\%, respectively), although no marker residues of albendazole were detected. Therefore, the presence of antiparasitic drug residues in milk did not seem to be the cause of the non-compliant results in the BRT MRL test.

The high occurrence of the non-compliant results in the BRT MRL test after the treatment with albendazole could be related to alterations of the immune system of the animals although there is not much information on this aspect. For instance, levamisole, a drug of the benzimidazole (anthelmintic) family, being active against various parasites (cestodes, trematodes and nematodes), acts unspecifically, restoring the cellular and humoral immune response in animals (Sajid et al., 2006). In bovines, levamisole stimulates the differentiation of $\mathrm{T}$ lymphocytes and their response to antigens; it also increases the activity of macrophages and neutrophils (Tizard, 2009). In addition, interferences on the microbial test response might be also related to the stress produced in goats by the treatment. In dairy livestock, stress has been associated to changes in some physiological and biochemical indicators (Trevisi and Bertoni, 2009) that could be related to the presence 
of inhibitory substances in milk (Yagi et al., 2004) able to affect the performance of the microbial inhibitor tests.

\section{Conclusions}

Residues in goat milk after the treatment of the animals with albendazole were below $M R L$ from the third day post-administration and, therefore, the dose and withdrawal period established for the use of Ovidax ${ }^{\circledR}$ in sheep could be applied to dairy goats treated under cascade without risk to the consumers' safety regarding the consumption of the milk.

However, a high percentage of positive results were obtained for the BRT MRL test during the first week after treatments, even when albendazole metabolites were no longer detected in goat milk. Therefore, although milk safety is not compromised when antiparasitic treatment with albendazole is properly performed, the detection of antibiotic residues in milk by microbial screening test could be affected during several days after treatment, which could lead to the milk being banned, resulting in serious economic losses for the farmers and dairies.

\section{Acknowledgements}

This work is part of the AGL-2009-11524 funded by the Ministry of Science and Innovation (Madrid, Spain) and the Generalitat Valenciana (ACOMOP/2012/164, Valencia, Spain). The authors are grateful to AiM Analytik in MilchProduktions-und Vertriebs-GmbH (Munich, Germany), DSM Food Specialties (Delft, the Netherlands) and ZEULAB S.L. (Zaragoza, Spain) for their support.

\section{References}

Botsoglou, N.A., Fletouris, D.J. 2001. Anthelmintic drugs. pp 117-154. In: Drug residues in foods, pharmacology, food safety, and analysis. Marcel Dekker Inc., New York.

Campbell, W. 1990. Benzimidazole: veterinary uses. Parasitol. Today. 6: 130-133.

Cinquina, A., Longo, F., Raponi, A., Bocsa, A., Cozani, R. 1997. Pharmacokinetic albendazole metabolites in goat milk and milk products. Ital. J. Food Sci. 9: 231-237.

Commission Regulation (EU) No 37/2010 of 22 December 2009 on pharmacologically active substances and their classification regarding maximum residue limits in foodstuffs of animal origin. Off. J. Eur. Union 2009 L15: 1-72.

Danaher, M., De Ruyck, H., Crooks, S.R.H., Dowling, G., O'Keeffe, M. 2007. Review of methodology for the determination of benzimidazole residues in biological matrices. J. Chromatogr. B. 845: 1-37. 
De Liguoro, M., Longo, F., Brambilla, G., Cinquina, A., Bocca, A., Lucisano, A. 1996. Distribution of the anthelmintic drug albendazole and its major metabolites in bovine milk and milk products after a single oral dose. J. Dairy Res. 63: 533-42.

Fabre, J.M., Moretain, J.P., Ascher, F., Brouillet, O., Berthelot, X. 1995. Main causes of inhibitors in milk. A survey in one thousand French dairy farms. In: Residues of Antimicrobial Drugs and other Inhibitors in Milk. IDF S.I. 9505: 27-31. International Dairy Federation, Brussels, Belgium.

Houtert, M.F., Sykes, A.R. 2010. Implications of nutrition for the ability of ruminants to withstand gastrointestinal nematode infections. Int. J. Parasitol. 26: 1151-1167.

Hoste, H., Chartier, C., Etter, E., Goudeau, C., Soubirac, F, Le Frileux, Y. 2000. A questionnaire survey on the practices adopted to control gastrointestinal nematode parasitism in dairy goat farms in France. Vet. Res. Commun. 24: 459-469.

Hoste, H., Sotiraki, S., Landau, S.Y., Jackson, F., Beveridge, I. 2010. Goat-Nematode interactions: think differently. Trends Parasitol. 26: 376-381.

Kumar, M.P., Rao, Y.M., Apte, S. 2007. Improved bioavailability of albendazole following oral administartion of nanosuspension in rats. Curr. Nanosci. 3: 191-194.

Moreno, L., Imperiale, F., Mottier, L., Alvarez, L., Lanusse, C. 2005. Comparison of milk residue profiles after oral and subcutaneous administration of benzimidazole anthelmintics to dairy cows. Anal. Chim. Acta. 536: 91-99.

Moreti, D.L.C., Lopes, R.A., Vinha, D., Sala, M.A., Semprini, M., Friedrichi, C. 2005. Effects of albendazole on rat fetuses liver: morphologic and morphometric studies. International J. Morphol. 23: 111-120.

Park, Y.W., Juárez, M., Ramos, M., Haenlein, G.F.W. 2007. Physico-chemical characteristics of goat and sheep milk. Small Rumin. Res. 68: 88-113.

Prieto, J.G., Merino, G., Pulido, M.M., Estevez, E., Molina, A.J., Vila, L., Alvarez, A.J. 2003. Improved LC method to determine ivermectin in plasma. J Pharmaceut. Biomed. 31: 639645.

Regulation (EC) No 853/2004 of the European Parliament and of the Council of 29 April 2004 laying down specific hygiene rules for on the hygiene of foodstuffs. Off. J. Eur. Union 2004 L139: 55-05.

Sajid, M.S., Muhammad, G., Iqbal, M.U. 2006. Immunomodulatory effect of various antiparasitics: a review. Parasitology. 132: 301-313. 
Su, S.C., Chang, C.L., Chang, P.C., Chou, S.S. 2003. Simultaneous determination of albendazole, thiabendazole, mebendazole and their metabolites in livestock by high performance liquid chromathography. J. Food Drug Anal. 11: 307-319.

Teruel, M., Felipe, A., Solana, H., Sallovitz, J., Lanusse, C. 2003. Placental and fetal toxicity of albendazole sulphoxide in Wistar rats. Vet. Hum. Toxicol. 3: 131-136.

Tizard, I.R. 2009. Drugs and other agents that affect the immune system. pp. 487-488. In: Veterinary immunology: an introduction. (Ed.). St Louis, Mo. Saunders Elsevier.

Trevisi, E., Bertoni, G. 2009. Some physiological and biochemical methods for acute and chronic stress evaluation in dairy cows. Ital. J. Anim. Sci. 8: 265-286.

Waller, P.J. 1997. Sustainable helminth control of ruminants in developing countries. Vet. Parasitol. 71: 195-207.

Yagi, Y., Shiono, H., Chikayama, Y., Ohnuma, A., Nakamura, I., Yayou, K.I. 2004. Transport stress increase somatic cell in milk, and enhances the migration capacity of peripheral blood neutrophils of dairy cows. J. Vet. Med. Sci. 66: 381-387.

Zanzani, S.A., Gazzonis, A.L., Di Cerbo, A., Varady, M., Manredi, M.T. 2014. Gastrointestinal nematodes of dairy goats, anthelmintic resistance and practices of parasite control in Northern Italy. BMC Vet. Res. 10: 114. 


\title{
Interferences on microbial inhibitor tests related to ivermectin treatment in dairy goats
}

\begin{abstract}
The aim of this study was to evaluate the response of microbial inhibitor tests on goat milk containing ivermectin residues. Ivermectin is not authorized for use in lactating animals producing milk for human consumption but in practice ivermectin is sometimes applied by goat farmers despite the veterinary drug has no registration for such a use. Twenty-eight Murciano-Granadina goats infested with Sarcoptes scabiei var. caprae were treated with a subcutaneous injection of ivermectin (200 $\mu \mathrm{g} / \mathrm{kg}$ b.w.). Seven days later a second dose of ivermectin was applied to prevent re-infestation since at the first treatment the cycle of the of the parasite was not yet completed. Up to fifteen days after treatment, individual milk samples were collected from treated animals on a daily basis. Ivermectin residues were quantified by HPLC, and the milk samples were also analysed by microbial inhibitor tests: BRT MRL, Delvotest SP-NT MCS and Eclipse 100. Drug residues in milk were detected along the fifteen days of the experiment at concentrations ranging from 8.13 to $24.25 \mathrm{ng} / \mathrm{ml}$, reaching the maximum value on the third day after the second drug administration. In addition, milk samples containing ivermectin tested positive for BRT MRL (20\%), Delvotest SP-NT MCS (6.6\%) and Eclipse 100 (5.7\%). However the response could not be fully associated with the ivermectin concentration in milk. Possibly the application of parasiticides or the parasitic disease itself affect the immune response of the animals favouring the presence of inhibitory substances in milk. Therefore, it can be concluded that the unauthorized application of ivermectin in lactating dairy goats results not only in persistent drug residues in the milk but also in an increase of antimicrobial substances in the milk so that in part of the cases positive results for microbial inhibitor tests could be obtained.
\end{abstract}

Key words: goat milk, ivermectin, microbial inhibitor tests. 


\section{Introduction}

Sarcoptic mange produced by Sarcoptes scabiei is a serious parasitic disease, more acute than the other forms of mange in that it may affect the entire body surface in a short time through contact among infected animals (Airlan, 1989). The clinical signs of this parasitic infestation are the appearance of small pruritic nodules especially on the head, hyperkeratosis and alopecia (Walton et al., 2004; Menzano et al., 2007). Besides, these symptoms are accompanied by excoriation and weight loss and can cause a significant reduction in milk production (Hoste and Cartier, 1998; Fthenakis et al., 2000; Walton and Currie, 2007).

The Sarcoptes scabiei var. caprae is one of the most common ectoparasites in caprine livestock and the disease often results in severe economic constraints on goat production across the world. Therefore, the antiparasitic treatment of goats infested with sarcoptic mange is necessary to avoid the spread of the disease and maintain the good health state of the animals.

In recent years the use of endectocides has become widespread in farming to combat parasitic diseases, since they are effective against both internal and external parasites. Among these drugs, ivermectin, belonging to the macrocyclic lactones group, standout displaying a high efficacy against a wide spectrum of nematode species and many arthropod parasites, causing neuromuscular blockades and eventually the death of the parasite (McKellar and Benchaoui, 1996).

Ivermectin is mainly excreted in faeces, but due to its fat affinity it is also depleted through milk, presenting a very long elimination period in cattle (Alvinerie et al., 1997) and sheep (Cerkvenik et al., 2004; Fernanda et al., 2004). Formulations based on ivermectin for the oral or parenteral application in livestock are now available. The Maximum Residue Limit (MRL) of ivermectin has been established in Europe (Commission Regulation (EU) No 37/2010) for all mammalian food producing species in fat, liver and kidney (100, 100 and 30 $\mu \mathrm{g} / \mathrm{kg}$, respectively). However, the use of ivermectin formulations has not been authorised in animals from which milk is produced for human consumption.

Moreover, it should be noted that many antiparasitic drugs are not registered for the use in dairy sheep and goats, especially in the latter. Only a small number of drugs is registered for their use and some lack sufficient efficacy to treat specific disease conditions. For the use in small ruminants veterinarians often have to resort to the use of drugs under 'cascade', in which the therapy relies on the extrapolation of knowledge of products available 
for similar parasitic infestations in other animal species (Directive (EC) 2004/28 amending Directive (EC) 2001/82).

There are indications that ivermectin is still illegally used to control the sarcoptic mange in intensive farms of dairy goats which are a fairly common problem during lactation. Therefore it is necessary to determine ivermectin residues in milk.

On the other hand, monitoring the presence of antibiotic residues above the MRLS (Commission Regulation (EU) No 37/2010) or residues of unauthorised products is mandatory in the EU (Regulation (EC) No 853/2004). Microbial inhibitor tests are widely used for screening antibiotics in raw milk. However they are non-specific and antiparasitic drugs have also been cited as a possible cause of (false) positive outcomes in microbial screening tests (Fabre et al., 1995).

Therefore, the aim of this study was to evaluate the response of microbial inhibitor tests in milk from goats treated with ivermectin.

\section{2. Material and methods}

\subsection{Animals, antiparasitic treatment and milk sampling}

The study was carried out using twenty-eight Murciano-Granadina goats of a body weight between $55-65 \mathrm{~kg}$ from the experimental farm of the Institute of Animal Science and Technology of Universitat Politècnica de València (UPV, Valencia, Spain). Animal procedures and management protocols were approved by the Ethics Committee of UPV.

Animals infested with sarcoptic mange (Sarcoptes scabiei var. caprae) identified by microscopic examination of skin scrapings taken from the infested zones (mainly head, vagina and tail) in the fifth month of lactation were employed in this study. The goats had received no antibiotic or antiparasitic drug prior to the experiment and their health was closely monitored throughout the trial.

The goats were treated with a sterile solution of Ivomec ${ }^{\circledR} \quad$ (Merial Laboratorios S.A., Madrid, Spain; $1.0 \%$ ivermectin) by subcutaneous injection with an automatic syringe (HSW Ferro-Matic $^{\circledR}$, Henke-Sass Wolf $\mathrm{GmbH}$, Tuttlingen, Germany) in the shoulder area. The manufacturer's recommendations for ovine species were followed. The dose of the product administered was $0.2 \mathrm{ml} / 10 \mathrm{~kg}$ b.w. (200 $\mu \mathrm{g}$ of ivermectin per $\mathrm{kg}$ b.w.), applying the same dose to all animals (1.2 ml/goat). To prevent re-infestation, a second dose of ivermectin was administered ( $200 \mu \mathrm{g}$ of ivermectine per kg b.w.) seven days after the first treatment. 
The animals were milked in a milking parlour (high line; CASSE $2 \times 12 \times 6$, Alfa Laval, Lund, Sweden) and sampling took place each morning (08:00 a.m.) for 15 days starting the day after after the first administration. From each individual milk sample, three aliquots were frozen $\left(-80^{\circ} \mathrm{C}\right)$ for ivermectin quantification by HPLC. Moreover, all milk samples were analysed, in triplicate, by microbial screening tests within 4 hours after sampling.

\subsection{Ivermectin quantification}

Extraction procedures and derivatisation to quantify ivermectin (IVM) were carried out following the technique described by Imperiale et al. (2004). However, chromatographic conditions were slightly modified as described below.

Sep-Pak C18 (Waters Cromatografia, S.A., Barcelona, Spain) previously conditioned with $1 \mathrm{ml}$ of methanol, followed by $1 \mathrm{ml}$ of water was used. Experimental milk extraction (100 $\mu \mathrm{l}$ ) with IVM was analysed using a Waters HPLC system (Milford, MA, USA), which included two pumps (Mod. 515, Waters), an autosampler (Mod. 717 plus, Waters), and a fluorescence detector (Mod. 474, Waters) set at an excitation wavelength of $365 \mathrm{~nm}$ and an emission wavelength of $475 \mathrm{~nm}$. The separation in isocratic form was achieved using a Nova-Pack C18 column (Waters, $4 \mu \mathrm{m}, 3.9 \times 150 \mathrm{~mm}$ ) coupled with a guard column NovaPack C18 (3.9 $\times 2 \mathrm{~mm})$ at $35^{\circ} \mathrm{C}$. The mobile phase consisted of a methanol/water mix (97:3, $\mathrm{v} / \mathrm{v}$ ) using a flow rate of $1.8 \mathrm{ml} / \mathrm{min}$. IVM was identified by comparison with retention time of a reference standard and IVM concentration was calculated using an internal standard (abamectin, ABM). The standards of IVM (18898) and abamectin (31732) were provided by Sigma-Aldrich (Sigma-Aldrich Química, S.A., Madrid, Spain).

The $C C \beta$ (detection limit) and CC $\alpha$ (quantification limit) were calculated according to Prieto et al. (2003). The CC $\beta$ and CC $\alpha$ values obtained for IVM were $0.13 \mathrm{ng} / \mathrm{ml}$ and 0.43 $\mathrm{ng} / \mathrm{ml}$, respectively. Average ivermectin recovery was $92.7 \%$.

\subsection{Microbial inhibitor tests}

Goat milk samples were analysed by microbial inhibitor tests: Brilliant Black Reduction Test MRL (BRT MRL, Analytik in MilchProduktions-und Vertriebs-GmbH, Munich, Germany), Delvotest SP-NT MCS (DSM Food Specialties, Delft, Netherlands) and Eclipse 100 (ZEULAB S.L., Zaragoza, Spain). The tests were used according to each manufacturer's instructions. A negative control (antimicrobial-free goat milk) and a positive control (antimicrobial-free goat milk spiked with $4 \mu \mathrm{g} / \mathrm{kg}$ of benzylpenicillin) were included in each test plate. Visual interpretation of the test results was carried out independently by three trained technicians assessing the colour change in the test medium; classifying milk samples 
as "positive" when the colour remained purple/blue and "negative" when the colour changed to yellow.

\subsection{Statistical analysis}

Statgraphics Centurion XVI software (16.1.03) (StatPoint Technologies, Inc., Warrenton, VA, USA) was used for statistical analyses.

The non-parametric Kruskal-Wallis test (K-W) was applied to analyse statistical differences ( $p<0.05$ ) of IVM concentrations with respect to days post-treatment. Subsequently, the Bonferroni test was performed to establish the differences along the days post-treatment.

\section{Results and discussion}

Figure 1 shows the results of quantitative analyses by HPLC for ivermectin in goat milk samples along the experimental period. Ivermectin residues were found in milk at 24 hours post-treatment $($ median value $=11.3 \mathrm{ng} / \mathrm{ml}$ ), increasing significantly $(p<0.05)$ during the second $(20.1 \mathrm{ng} / \mathrm{ml})$, third $(21.0 \mathrm{ng} / \mathrm{ml})$, and fourth day $(19.9 \mathrm{ng} / \mathrm{ml})$ and then gradually decreasing until the seventh day $(13.6 \mathrm{ng} / \mathrm{ml})$. The second application of ivermectin increased $(p<0.05)$ the concentration of residues in goat milk significantly on the eighth $(21.3$ $\mathrm{ng} / \mathrm{ml})$, ninth $(22.3 \mathrm{ng} / \mathrm{ml})$ and tenth day $(24.3 \mathrm{ng} / \mathrm{ml})$, with respect to the residual levels detected before the second drug administration.

As shown in Figure 1, a great variability in the ivermectin concentration throughout the experimental period was observed, especially on the days after drug application, showing individual differences in the excretion levels of this substance in milk after antiparasitic treatment.

Studies on the pharmacokinetics and mammary excretion of ivermectin in goats are limited. Scott et al. (1990) evaluated the residues of ivermectin in plasma and milk from goats using two different routes of administration: oral (200 $\mu \mathrm{g} / \mathrm{kg} \mathrm{b.w.)}$ and percutaneous (500 $\mu \mathrm{g} / \mathrm{kg}$ b.w.). Alvineire et al. (1993) employed a single subcutaneous administration of ivermectin $(200 \mu \mathrm{g} / \mathrm{kg}$ b.w.) in their study. These authors also found the highest concentrations of ivermectin in goat milk between 24 and 72 hours post-treatment, which gradually decrease on the days after. However, the maximum levels of the antiparasitic agent reported were below than those observed in this study. 


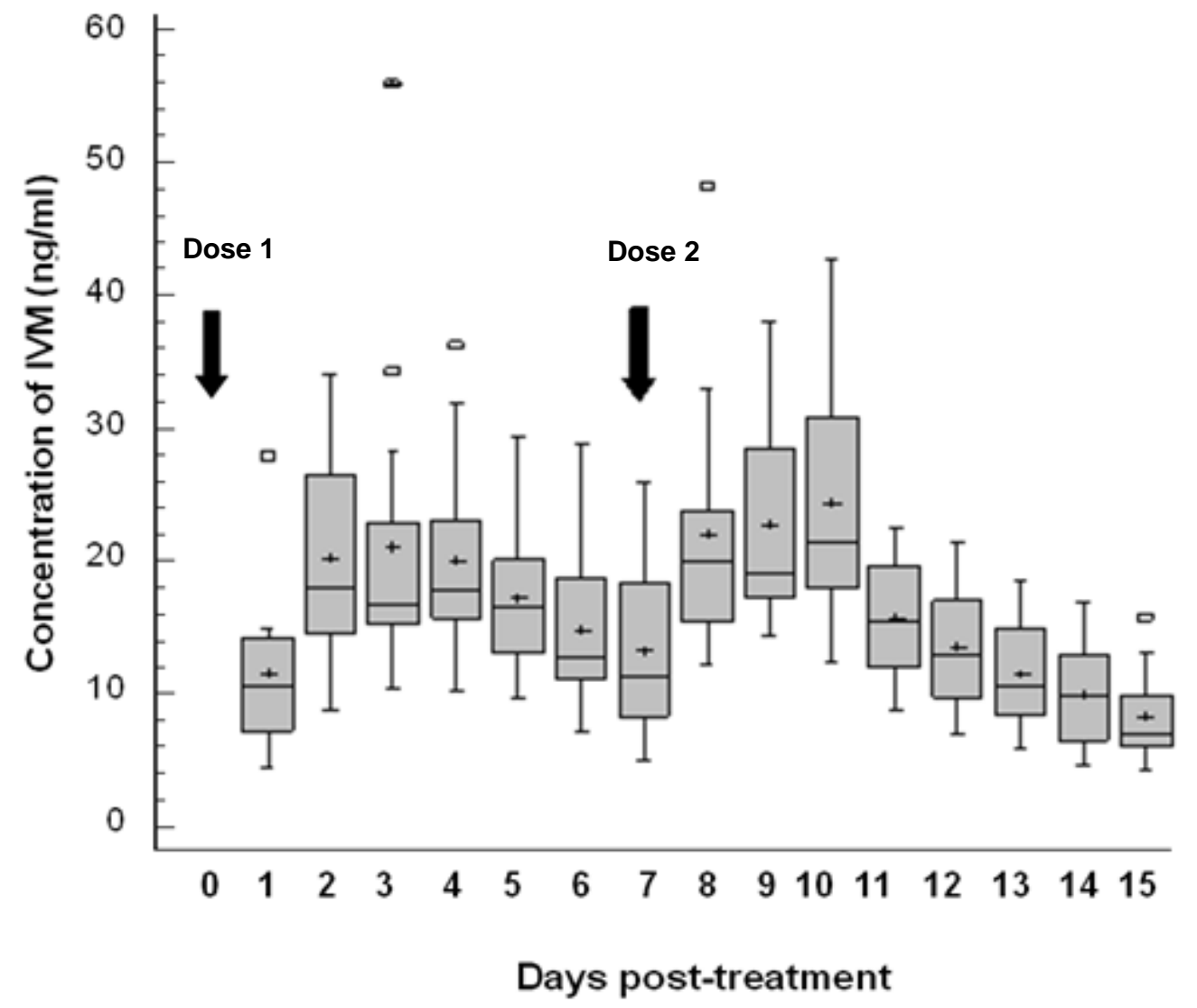

Figure 1. Box and whisker plots illustrating the concentration of ivermectin (IVM) in goat milk on the post-treatment days. The plots show the 25th and 75th percentiles (box), median $(-)$, mean $(+), 10$ th and 90th percentiles (whisker bars) and outliers ( $\square$ )

In dairy goats treated with a subcutaneous injection of ivermectin (300 $\mu \mathrm{g} / \mathrm{kg} \mathrm{b.w.),} \mathrm{Li} \mathrm{et}$ al. (1993) obtained the highest concentration of ivermectin residues in milk between the first three days after treatment $(24 \mathrm{ng} / \mathrm{ml})$ similar to that calculated in this study $(20.9 \mathrm{ng} / \mathrm{ml})$. No residues were found by these authors after 8 days post-treatment.

The differences observed with regard to the ivermectin concentration in milk between authors may be due to the different administration routes, i.e. the subcutaneous route confers a higher bioavailability in sheep, cow and goats compared to oral or topical administration as suggested by several authors (Campbell, 1985; Alvineire and Galtier 1997; Lespine et al., 2005). Moreover, it may also be due to different production levels as well as the milk composition from different goat breeds (Haelein, 2007). A higher fat content in milk may be related to a higher ivermectin concentration, due to the lipophilic nature of ivermectin (McKellar and Benchaoui, 1996). 
Regarding the effect of ivermectin residues on the response of microbial test for screening antibiotics in milk, Table 1 shows the positive results found along the experimental period considered.

Table 1. Positive results in microbial inhibitor tests in milk from goats $(n=28)$ treated with ivermectin

\begin{tabular}{|c|c|c|c|}
\hline \multirow{2}{*}{$\begin{array}{c}\text { Days } \\
\text { post-treatment }\end{array}$} & \multicolumn{3}{|c|}{ Positive results (\%) } \\
\hline & BRT MRL & Delvotest SP- NT MCS & Eclipse 100 \\
\hline 1 & 46.4 & 14.3 & 17.8 \\
\hline 2 & 32.1 & 7.4 & 7.4 \\
\hline 3 & 25.0 & 3.6 & 10.7 \\
\hline 4 & 21.4 & 7.4 & 3.6 \\
\hline 5 & 28.6 & 10.7 & 10.7 \\
\hline 6 & 7.4 & 10.7 & 7.4 \\
\hline 7 & 3.6 & 10.7 & 3.6 \\
\hline 8 & 35.7 & 10.7 & 3.6 \\
\hline 9 & 32.1 & 7.4 & 7.4 \\
\hline 10 & 17.8 & 10.7 & 7.4 \\
\hline 11 & 10.7 & 7.4 & 3.6 \\
\hline 12 & 14.3 & 0.0 & 3.6 \\
\hline 13 & 14.3 & 0.0 & 0.0 \\
\hline 14 & 10.7 & 0.0 & 0.0 \\
\hline 15 & 0.0 & 0.0 & 0.0 \\
\hline Average & 20.0 & 6.6 & 5.7 \\
\hline
\end{tabular}

As shown in Table 1, the Delvotest SP-NT MCS and Eclipse 100 tests presented a similar percentage of positive results throughout the experimental period $(6.6 \%$ and $5.7 \%$, respectively), while the BRT MRL test presented a larger number of positives outcomes $(20 \%)$. In all cases, the highest percentage of positive results was obtained on the first day 
post-treatment $(\mathrm{BRT} M R L=46.4 \%$; Delvotest SP-NT MCS $=14.3 \%$; and Eclipse $100=$ $17.8 \%)$. However, the BRT MRL test, as opposed to the other two microbial tests, showed a high percentage of positive outcomes along the five days post-treatment, which increased considerably after the second ivermectin application. It is noteworthy that the BRT MRL test contains Mueller-Hinton as culture medium and black brilliant as a redox indicator, while the Delvotest SP-NT MCS and Eclipse 100 test use plate count agar and bromocresol purple as $\mathrm{pH}$ indicator. These differences could be related to the increased occurrence of positive results in the BRT MRL test.

It is important to remark that the microbial screening tests used in this study present a good selectivity for goat milk. Thus, Beltrán et al. (2015) calculated a selectivity $\geq 97 \%$ in these tests, so that a small percentage of positive outcomes $(\leq 3 \%)$ could be attributed to false positive results associated with the goat milk characteristics and the presence of natural inhibitors. However, the percentage of positive outcomes obtained in the present study is much higher than that reported by these authors, which suggests that a high percentage of non-compliant results could be related to ivermectin treatments.

In this sense, Ujjwal and Dey (2010) evaluated the organ function and the oxidant/antioxidant status in goats with sarcoptic mange, and a higher concentration of biochemical indicators of oxidative stress in blood from mite-infected animals than in healthy animals was observed. This alteration at the biochemical level in blood due to sarcoptic mange could also influence milk composition, releasing substances with oxidative capacity which could affect the black brilliant indicator used in the BRT MRL test causing positive results. In addition, it should be noted that, in general, antiparasitic drugs show a redoxactive mechanism able to inhibit vital redox reactions or promote oxidative stress in parasites (Schirmer et al., 1987; Okayama, 2005). The BRT MRL test response could largely be affected by this property of antiparasitic agents as the redox indicator used in the test to evidence the microorganism-test growth.

Regarding the concentration of ivermectin residues in goat milk as a result of antiparasitic treatment, it was much lower than the concentration causing interferences in microbial screening tests reported in the previous in vitro study. This reserach indicate the inhibitory concentrations of ivermectin in goat milk resulting in $5 \%$ of positive results $\left(\mathrm{IC}_{5}\right)$ in microbial screening tests, i.e. $41 \mathrm{mg} / \mathrm{l}$ for the BRT MRL test; $83 \mathrm{mg} / \mathrm{l}$ for the Delvotest SP-NT MCS and $109 \mathrm{mg} / \mathrm{l}$ for the Eclipse 100 test, values far higher than those found in this work (Figure 1). In fact, the highest occurrence of positive results was obtained at 24 hours posttreatment (Table 1), when goat milk had a relatively low concentration of ivermectin residues 
$(11.3 \mathrm{ng} / \mathrm{ml})$, similar to that seen in the last days of the experimental period, in which only very few positive results were found. Therefore, the positive outcomes in microbial screening tests do not seem to be caused by the ivermectin concentration in goat milk, and would be produced by other factors related to the antiparasitic treatment and/or the response of the animals.

Among the possible factors which could interfere in the microbial test response, are the alterations and modifications generated by sarcoptic mange in the animal organism. Several studies have indicated that this parasitic disease, does not only present visible dermatological symptoms, but is also associated with physiological changes such as the increased pro-inflammatory cytokine levels in the blood from various skin cells (Arlian et al., 2003; Mullins et al., 2009), high total protein levels, y-globulin and IgG in the serum plasma of chamois (Lastras et al., 2000); and high levels of acute phase proteins (ceruloplasmin, a1acid glycoprotein, haptoglobin, and serum amyloid A) in the blood of mange-infested Alpine ibex (Rahman et al., 2010).

On the other hand, some antiparasitic drugs, as in the case of ivermectin, have been evaluated as immunomodulatory and show a favourable potential use as positive modulators (Stankiewwicz et al., 1995). In healthy rabbits, Sajid et al. (2007) studied the cellular immune and subsequent humoral response to treatment with various doses of ivermectin $(200,400$ and $600 \mu \mathrm{g} / \mathrm{kg}$ b.w.). The results of these experiments showed a significant effect on the kinetics of antibodies to a specific antigen. The potential changes in the immunological system of the animals as a result of the antiparasitic drug activity or the immune response of the animal to combat the parasitic disease, could result in the presence of inhibitory substances in milk capable of interfering with the test microorganism metabolism, resulting in non-compliant results in microbial screening tests. Therefore, it would be interesting to carry out investigations concerning the presence of inhibitory substances in goat milk related to defence mechanisms against parasitic diseases as well as antiparasitic treatments, on the response of microbial inhibitor tests.

\section{Conclusions}

Antiparasitic treatment with double subcutaneous injection of ivermectin in lactating dairy goats infested by sarcoptic mange produces residues in milk of up to fifteen days after agent application and possibly thereafter.

In addition, the antiparasitic treatment is leading to a high percentage of positive results for the microbial inhibitor test (ranging 5.7-20\%) that cannot be traced back to ivermectin residues. Thus, interferences could be related to changes or alterations caused by the 
application of the parasiticide ivermectin or by the parasitic disease itself that could affect the immune response of animals favouring the presence of inhibitory substances in milk.

It can be concluded that the illegal application of ivermectin in lactating dairy goats produces persistent drug residues in milk and could also eventually cause positive microbial inhibitor test results, however not related to the residues itself but to interference by certain inhibitory substances in the milk.

\section{Acknowledgements}

This work is part of the AGL-2009-11524 funded by the Ministry of Science and Innovation (Madrid, Spain) and the Generalitat Valenciana (ACOMOP/2012/164, Valencia, Spain). The authors are grateful to AiM Analytik in MilchProduktions-und Vertriebs-GmbH (Munich, Germany), DSM Food Specialties (Delft, the Netherlands) and ZEULAB S.L. (Zaragoza, Spain) for their support.

\section{References}

Airlan, L.G. 1989. Biology, host relations, and epidemiology of Sarcoptes scabiei. Annu. Rev. Entomol. 34: 139-161.

Airlan, L.G., Morgan, M.S., Neal, J.S. 2003. Modulation of cytokine expresión in human keratinocytes and fibroblasts by extracts of scabies mites. Am. J. Trop. Med. Hyg. 69: 652-656.

Alvinerie, M., Sutra, J. F., Galtier, P. 1993. Ivermectin in goat plasma and milk after subcutaneous injection. Ann. Rech. Vet. 24: 417-421.

Alvinerie, M., Galtier, P. 1997. Comparative pharmacokinetic properties of moxidectin and ivermectin in different animal species. J. Vet. Pharmacol. Ther. 20: 74.

Beltrán, M.C., Berruga, M.I., Molina, A., Althaus, R.L., Molina M.P. 2015. Performance of the current microbial tests for screening antibiotic in sheep and goat milk. Int. Dairy J. 41: 1315.

Campbell, W. 1985. Ivermectin: an update. Parasitol. Today. 1: 10-17.

Cerkvenik, V., Bogdan, B., Rogeli, I., Doganoc, D., Skubic, V., Beek, W. 2004. Fate of ivermectin residues in milk and derived products. J. Dairy Res. 71: 39-45.

Commission Regulation (EU) No 37/2010 of 22 December 2009 on pharmacologically active substances and their classification regarding maximum residue limits in foodstuffs of animal origin. Off. J. Eur. Union 2009 L15: 1-72. 
Directive (EC) 2001/82 of the European Parliament and of the Council of 6 November 2001 on the Community code relating to veterinary medicinal products. Off. J. Eur. Union 2001 L311: 1-66.

Directive (EC) 2004/28 of the European Parliament and of the Council of 31 March 2004 amending Directive $2001 / 82 / E C$ on the Community code relating to veterinary medicinal products. Off. J. Eur. Union 2004 L136: 58-84.

Fabre, J.M., Moretain, J.P., Ascher, F., Brouillet, O., Berthelot, X. 1995. Main causes of inhibitors in milk. A survey in one thousand French dairy farms. In: Residues of Antimicrobial Drugs and other Inhibitors in Milk. IDF S.I. 9505: 27-31. International Dairy Federation, Brussels, Belgium.

Fernanda, A., Imperiale, F., Margarita, R., Lanusse, E. 2004. Milk excretion of ivermectin and moxidectin in dairy sheep cheese elaboration. Food Chem. 52: 6205-6211.

Fthenakis, G. C., Papadopulos, E., Himonas, C., Leontide, L., Kritas, S., Papatsas, J. 2000. Efficacy of moxidectin against sarcoptic mange and effects on milk yield of ewes and growth of lambs. Vet. Parasitol. 87: 207-216.

Haenlein, G.F.W. 2007. About the evolution of goat and sheep milk production. Small Rumin. Res. 68: 3-6.

Hoste, H., Chartier, C. 1998. Response to challenge infection with Haemonchus contortus and Trichostrongylus colubriformis in dairy goats. Consequences on milk production. Vet. Parasitol. 74: 43-54.

Imperiale, F., Lifschitz, A., Sallovitz, J., Virkel, G., Lanusse, C. 2004. Comparative depletion of ivermectin and moxidectin milk residues in dairy sheep after oral and subcutaneous administration. J. Dairy Res. 71: 427-433.

Lastras, M.E., Pastor, J., Marco, I., Ruiz, M., Viñas, L., Lavin, S. 2000. Effects of sarcoptic mange on serum proteins and immunoglobulin $G$ levels in chamois (Rupicabra pyrenaica) and Spanish ibex (Capra pyrenaica). Vet. Parasitol. 88: 131-319.

Lespine, A., Alvineire, M., Sutra, J.F., Pors, I., Chartier, C. 2005. Influence of the route of administration on efficacy and tissue distrinution of ivermectin in goat. Vet. Parasitol. 128: 251-260.

Li, M.T., Guo, W.L., Zhong, F., Yao, D.L. 1993. Study on ivermectin residues in goat milk. Acta Vet. Zoot. Sinica. 24: 52-56. 
Menzano, A., Rambozzi, L., Rossi, L. 2007. A severe episode of wildlife-derived scabies in domestic goats in Italy. Small Rumin. Res. 70: 154-158.

McKellar, Q.A., Benchaoui, H.A. 1996. Avermectins and milbemycins. J. Vet. Pharmacol. Ther. 19: 331-351.

Mullins, J.S., Arlian, L.G., Morgan M.S. 2009. Extracts of Sarcoptes scabiei De Geer down modulate secretion of IL-8 by skin keratinocytes and fibroblasts and of GM-CSF by fibroblasts in presence of proinflamatory cytokines. J. Med. Entomol. 46: 845-851.

Okayama, Y. 2005. Oxidative stress in allergic and inflamatory skin diseases. Curr. Drug Targets Inflamm. Allergy. 4: 517-519.

Prieto, J.G., Merino, G., Pulido, M.M., Estevez, E., Molina, A.J., Vila, L., Alvarez, A.J. 2003. Improved LC method to determine ivermectin in plasma. J Pharmaceut. Biomed. 31: 639645.

Rahman, M., Lecchi, C., Fraquelli, C., Sartorelli, P., Ceciliani, F. 2010. Acute phase protein response in Alpine ibex with sarcoptic mange. Vet. Parasitol. 168: 293-298.

Regulation (EC) No 853/2004 of the European Parliament and of the Council of 29 April 2004 laying down specific hygiene rules for on the hygiene of foodstuffs. Off. J. Eur. Union 2009 L139: 55-205.

Sajid, M.S., lqbal, Z., Muhammad, G., Sandhu, M.A., Khan, M.N. 2007. Effect of ivermectin on the cellular and humoral immune responses of rabbits. Life Sci. 80: 1966-1970.

Schirmer, R.H., Schollhammer, T., Eisenbrand, G., Krauth-Siegel, R.L. 1987. Oxidative stress as a defense mechanism against parasitic infections. Free Radical Res. Com. 3: 312.

Scott, E.W., Kinabo, L.D., McKellar, Q.A. 1990. Pharmacokinetics of ivermectin after oral or percutaneous administration to adult milking goats. J. Vet. Pharmacol. Ther. 13: 432-435.

Stankiewicz, M., Cabaj, W., Jonas, W.E., Moore, L.G., Millar, K., Chie, W. 1995. Influence of ivermectina on cellular and humoral immune responses of lambs. Vet. Immunol. Immunopathol. 44: 347-358.

Ujjwal, K.D., Dey, S. 2010. Evaluation of organ function and oxidant/antioxidant status in goats with sarcoptic mange. Trop. Anim. Health Prod. 42: 1663-1668.

Walton, S.F., Currie, B.J. 2007. Problems in diagnosing scabies, a global disease in human and animal population. Clin. Microbiol. Rev. 20: 268-279. 
Walton, S. F., Holt, D.C., Currie, B.J., Kemp, D.J. 2004. Scabies: new future for a neglected disease. Avd. Parasitol. 57: 309-376. 



\section{Chapter 6}

Impact of goat milk quality and composition on the response of microbial inhibitor tests 



\title{
Influence of goat milk quality on the response of microbial inhibitor tests
}

\begin{abstract}
Microbiological inhibitor tests can cause false positive results when testing goat milk on the presence of antimicrobial residues. The aim of this study was to compare the response of the microbiological screening tests and to evaluate the impact of the composition and the quality of goat milk on the rate of false positive results. Finally was attempted to limit this rate by the application of a special pre-treatment of milk samples.

Two hundred and ten individual milk samples of White Saanen goats were used in the study. To compare the results of the tests, the milk samples were tested within 14-20 hours after collection by means of three microbial inhibitor tests: BRT MRL, Delvotest SP-NT MCS and Eclipse 100. Each microbial test was performed in duplo, and the interpretation of the results was carried out visually and instrumentally. To evaluate the impact of the composition and quality of goat milk on the response of microbial tests, one hundred and ten antibiotic-free milk samples were used. The physico-chemical composition (fat, protein, lactose, urea), hygienic-sanitary parameters (somatic cell count, bacterial count, etc), fatty acids, lipolysis, fat oxidation, natural inhibitors (lysozyme, lactoferrin, lactoperoxidase), and other milk parameters ( $\mathrm{pH}$, freezing point) were analysed.
\end{abstract}

Samples initially tested as positive were retested and tested after a milk pre-treatment (heat treatment, fat removal, fat removal followed by heat treatment) in an attempt to lower the false positive rate.

The results showed that most of microbial tests are suitable to test goat milk giving a rate of false positive results < 5\%, except for Delvotest SP-NT MCS ( $6 \%$ of false positive rate). The visual reading decreased the specificity for all methods, being statistically different $(p<0.05)$ for BRT MRL and Eclipse 100. A logistic regression model was applied to investigate the effect of the components in goat milk on the microbial test response evaluated by instrumental and visual reading. The increment of false positive results for visual interpretation showed variability of results for each microbial test, and in general was associated with the increase of fat content, $\mathrm{pH}$ values, lactoferrin, butyric and myristoleic acid. However for instrumental reading the logistic regression analysis showed that BRT MRL and Eclipse 100 were unaffected by the parameters studied, while in Delvotest SP-NT MCS the false outcomes were related with some milk properties as the $\mathrm{pH}$ values, lactoferrin and myristoleic acid. 
Chapter 6

The best sample pre-treatment was fat removal followed by heat treatment, as $100 \%$ negative results were obtained for Eclipse 100 and the percentage of false positive results dropped by $55 \%$ for Delvotest SP-NT MCS.

Keywords: goat milk, microbial tests, natural inhibitors, false positive results. 


\section{Introduction}

Currently, antibiotic residues in milk are still of great concern to different sectors such as milk producers, the dairy industry, regulatory agencies and consumers. Due to the intensification of milk production by small ruminants in recent years, the use of antibiotics as veterinary drugs in dairy goats has become an usual practice in veterinary medicine to treat mastitis and others diseases (Buswell et al., 1989; Silanikove et al., 2010). Veterinary drug residues in milk might pose a risk to health, may generate allergies or toxic reactions (Alanis, 2005; Demoly and Romano, 2005; Sanders et al., 2011) and may cause technological implications for the manufacturing of dairy products, especially of cheese and yogurt (Packham et al., 2001; Adetunji, 2011; Berruga et al., 2011).

Generally, dairy goat husbandry in Europe is most common around the Mediterranean basin. Greece, Spain, France and Italy are the largest producers of the goat milk. Normally, this milk is intended for cheese making and yogurt production, most of the time on an artisanal level.

An important problem is that many antibiotics used in dairy goats are only registered for dairy cattle and the withdrawal period for goats cannot be extrapolated accurately, since the depletion data were generated for a different animal species (Karzis et al., 2007; Ferrini et al., 2010).

The European Union established Maximum Residue Limits (MRLs) for veterinary medicinal products in Commission Regulation (EU) No 37/2010, as foreseen in Commission Regulation (EU) No 470/2009. The control of inhibitor substances has been legislated by Regulation No 853/2004 and amendments, within the specific rules of hygiene of foodstuffs of animal origin, including the raw milk of small ruminants. For this reason the presence of antibiotics in milk is routinely screened at farms, dairies and laboratories.

Microbial inhibitor tests are widely used to detect antibiotics, because such tests are quick, easy to use, and relatively cheap and can detect a wide spectrum of compounds. Microbial screening methods are based primarily on the evidence of inhibition of the growth of a specific organism. Different systems as indicators of $\mathrm{pH}$, redox, or bioluminescence are used for the detection of this inhibition. These methods primarily take advantage of the ability of bacteria to produce acid, reduce dyes or produce inhibition halos in a culture medium, so that the result can be interpreted visually or instrumentally. The microorganism most used in these tests is Geobacillus stearothermophilus var. calidolactis. During the incubation period milk diffuse through the culture medium and if it contains sufficient quantity of antimicrobial substances the growth of the microorganism will be reduced or inhibited. 
Following Commission Decision 2002/657/EC as a general requirement for specificity it is stated that a method should be able to distinguish between the analyte (antibiotic) and the other substances under the experimental conditions. A positive test result is considered to be a false positive result when no antibiotics are present in the milk. Legislation does not mention an allowed percentage of false positive screening results but the percentage should remain reasonable limited. The Commission Decision 2002/657/EC, established a maximum percentage of false compliant results for screening methods, applied in conformity with Council Directive 96/23/EC. This percentage has to be less than $5 \%$ ( $\beta$-error). In parallel, a percentage of maximum $5 \%$ false positive results in microbial screening tests could be considered adequate or reasonable.

Several factors could contribute to false positive results on microbial inhibitors tests, since these tests are non-specific and may be affected by any substance or compound capable of inhibiting the growth of the test-organism. Natural inhibitors like lactoferrin and lysozyme (Carlsson and Björck, 1987; Carlsson et al., 1989; Pan et al., 2007), an elevated somatic cell count (Carlsson and Björck, 1989; Andrew, 2001), also feed complemented with minerals, oligo-elements and vitamins (Romnée et al., 1999), high concentrations of fatty acids (Mäyrä-Mäkinen, 1990; Carsson and Björck, 1992) and the lipodepsipeptides produced by certain Pseudomonas species (Reybroeck et al., 2014) among others factors have been related with false positive outcome results.

Most of the studies concerning the evaluation of microbiological methods have been carried out in cow (Halbert et al., 1996; Andrew et al., 1997; Kang et al., 2005) and ewe milk (Althaus et al., 2003; Molina et al., 2003), so limited information is available regarding false positive results for goat milk

Is important to remark that goat milk is characterized by a higher fat and protein content than cow milk (Park et al., 2007) as well as by an elevated content of natural inhibitors such as immunoglobulins, lactoferrin or lysozyme (Crosson et al., 2010) and a higher somatic cell count (SCC) even in absence of intra-mammary infections (Paape et al., 2007). These different characteristics in goat milk composition could be the causes of the interference in the response of microbial inhibitor tests.

On the other hand, false positive results can have serious consequences, as producers and the dairy industry are encountered with economic losses. Good milk will be discarded and a financial penalty will be given as a legal consequence for a positive test result in regulatory testing. Validation of the tests for goat milk is very important for the selection of 
the most appropriate testing strategy for a correct interpretation of the test results and to ensure good monitoring for antibiotics in dairy goat milk.

Thus, the aim of the study was to compare the response of microbial screening tests by an evaluation the impact of the composition and quality of goat milk.

\section{Material and methods}

This experimental study was carried out in the Technology and Food Science unit (Melle, Belgium) of the Institute for Agricultural and Fisheries Research (ILVO-T\&V).

\subsection{Milk samples}

Two hundred individual milk samples of White Saanen goats were collected from three Flemish goat farms with different feed management conditions, two of them use ecological feed (Johan Van Waes, Zaffelare, Belgium and 't Eikenhof, Lokeren, Belgium) and the third farm uses conventional ration ('t Leenhof, Zele, Belgium).

The milk sampling of different individual goats was performed in the evening milking, around 5 and 6 p.m. Each sample $(600 \mathrm{ml})$ was kept refrigerated at $\leq 4{ }^{\circ} \mathrm{C}$ until transport to the laboratory the next morning. On arrival, the samples were homogenized and divided in several aliquots $(50 \mathrm{ml})$ to perform the screening tests for antibiotics and to analyse the milk quality. Three aliquots of milk were kept frozen at $-30^{\circ} \mathrm{C}$ to determine the lactoferrin content, and the lysozyme and lactoperoxidase activity. The storage time was maximum 2 months.

\subsection{Microbial inhibitor tests}

Milk samples were tested 14-20 hours after milking by means of three different microbial inhibitor tests: Delvotest SP-NT MCS (DSM Food Specialties, Delft, the Netherlands), Brilliant Black Reduction Test MRL (BRT MRL) (Analytik in Milch Produktionsund Vertriebs GmbH, Munich, Germany), and Eclipse 100 (ZEULAB S.L., Zaragoza, Spain). All tests are based on the inhibition of the growth of the test microorganism Geobacillus stearothermophilus var. calidolactis, the colour indicator in Delvotest SP-NT MCS and Eclipse 100 is bromocresol purple, and for the BRT MRL it is brilliant black. All kits have a 96-well microtiter plate format.

In every run of each inhibitor test, blank reference milk (mixture of 6 negative goat milk samples) and antibiotic standards were included, these last doped in blank goat milk at different concentrations depending on the detection limit of each method. Oxytetracycline (O5875), benzylpenicillin (PENNA), sulfadiazine (S8626), and sulfadoxine (S7821), all from 
Sigma-Aldrich (Bornem, Belgium) were used as control standards. For all milk samples each microbial inhibitor test was performed in duplo.

All microbial inhibitor tests were incubated in a covered waterbath (Type $19+$ MP thermostat from Julabo Labortechnic $\mathrm{GmbH}$ (Seelbach, Germany)) at $64.0 \pm 0.2{ }^{\circ} \mathrm{C}$, except Eclipse 100 plates were incubated in a FX incubator (ZEULAB S.L.) at $65^{\circ} \mathrm{C}$. The incubation time is set by the manufacturer or indicated for the specific batches. However, some microbiological tests as BRT MRL or Delvotest SP-NT MCS required a longer incubation time (10 to 20 minutes) to obtain negative results for reference blank milk controls on each plate.

The interpretation of the results was carried out visually and instrumentally. The instrumental interpretation for Delvotest SP-NT MCS was done by means of a flatbed scanner (HP Scanjet 7400C, Hewlett-Packard Company, Palo Alto, CA) connected to DelvoScan software, version 3.05 (DSM Food Specialties); the cut-off was set at a Z-value = -3.00. BRT MRL and Eclipse 100 results were interpreted photometrically using a spectrophotometer (Multiskan EX, Thermo Scientific, Walthan, MA) with $450 \mathrm{~nm}$ (filter 1) and $620 \mathrm{~nm}$ (filter 2) for BRT MRL; the cut-off was fixed at a threshold value $=40 \%$, as recommended by the commercial company. The threshold value (\%) was calculated for each plate by measuring the absorbance of eight negative and positive controls (NC and PC, respectively), using the following conversion formula: (average sample absorbance - average NC)/(average PC - average NC) x $100=\%$ threshold value. Eclipse 100 was read using 590 $\mathrm{nm}$ (filter 1) and $650 \mathrm{~nm}$ (filter 2), the cut-off were set by the average absorbance for eight blank goat milk samples increased by 0.3 or 0.2 , respectively. By visual interpretation of the agar in the tests the samples were evaluated as "negative" (yellow colour), "positive" (bluepurple colour), and doubtful (intermediate colours between yellow/blue-purple).

To check that all milk samples used in the study was free of antibiotic residues, the milk samples with a positive result for any microbiological inhibitor test were tested after addition of $\beta$-Lactamase ES (Sekisui Enzymes West Malling, UK), 4-aminobenzoic acid (PABA) (Sigma-Aldrich, Bornem, Belgium) or $\mathrm{CaCl}_{2}$ (Merck KGaA, Darmstadt, Germany) and by means of different group-specific receptor-binding assays (Twinsensor BT, 3SENSOR, and 4SENSOR from Unisensor (Liège, Belgium); Charm MRL BLTET2 from Charm Sciences Inc. (Lawrence, MA) and Beta-star from Neogen Corporation (Lansing, MI). After the analyses by rapid tests, the positive samples were confirmed with a chromatography method (LC-MS/MS) at ILVO as described by Daeseleire et al. (2000). 


\subsection{Milk quality analysis}

To evaluate the impact of the composition and quality of goat milk on the response of microbial inhibitor tests, one hundred and ten antibiotic-free individually milk samples were used.

2.3.1. Determination of milk composition, somatic cell count, bacterial count, $\mathrm{pH}$ and freezing point

The fat, protein, lactose, freezing point and urea content of the milk samples were determined by a Milkoscan FT 6000 (Foss, Hillerød, Denmark), the somatic cell count (SCC) by a Fossomatic 5000 (Foss) and the bacterial count (BC) by a Bactoscan (Foss) at vzw Melkcontrolecentrum-Vlaanderen (Lier, Belgium). A SevenMulti $\mathrm{pH}$ meter was used from Mettler-Toledo Inc. (Columbus, $\mathrm{OH}$ ) for $\mathrm{pH}$-measurements.

\subsubsection{Determination of fatty acids, lipolysis and fat oxidation}

The profile of fatty acid and lipolysis determination was performed at Comité du Lait (Battice, Belgium) using Fourier Transform Mid Infa-Red technology (FTMIR) on a Milkoscan FT 6000 (Foss) (IDF 447:2010, IDF 2010). The fatty acids content was expressed as $\mathrm{g} / 100 \mathrm{~g}$ fat.

The fat oxidation (peroxide value) was determined at ILVO following AOAC Official Method 965.93. The peroxide value was determined by measuring the amount of iodine liberated from a potassium iodide solution at room temperature. The liberated iodine is expressed in meq $\mathrm{O}_{2} \mathrm{~kg}^{-1}$ fat. All the reagents were supplied by Sigma-Aldrich and Merck KGaA.

\subsubsection{Determination of lactoferrin, lysozyme and lactoperoxidase activity}

Lactoferrin analyses were done using the Goat Lactoferrin (LTF) Elisa Kit test (BlueGene Biotech, Shanghai, China), a competitive enzyme immunoassay, utilizing a monoclonal anti-lactoferrin antibody and lactoferrin-HRP conjugate to quantify the lactoferrin concentration $(\mu \mathrm{g} / \mathrm{ml})$. To determine the optical density a Multiskan EX spectrophotometer) was used at $450 \mathrm{~nm}$.

Lysozyme activity was determined using a EnzChek® lysozyme assay kit (E-22013, Molecular Probes Inc., Eugene, OR). This assay measures the lysozyme activity on Micrococcus lysodeikticus cell walls, which are labeled to such a degree that the fluorescence is quenched. The fluorescence intensity was measured using a spectrofluorometer (FLUOstar optima, BGM LABTECH GmbH, Germany) at excitation 
wavelength of $485 \mathrm{~nm}$ and emission wavelength of $510 \mathrm{~nm}$. Lysozyme activity was expressed as units per millilitre $(\mathrm{U} / \mathrm{ml})$.

Lactoperoxidase activity was estimated according to IDF 208:2011 (IDF, 2011) photometric method. The ABTS [2.2'-azino-bis (3-ethylbenzothiazoline-6-sulfonic acid)] is catalytically converted to its radical cation (ATBS+) at a pH of 6.0 and at $25{ }^{\circ} \mathrm{C}$. The amount of ABTS+ liberated per unit of time is proportional to the lactoperoxidase activity and measured photometrically at $420 \mathrm{~nm}$ (Multiskan EX spectrophotometer). The lactoperoxidase activity is expressed in units per litre (U/I). The reagents were supplied by Sigma-Aldrich.

All milk samples were analysed in duplicate following the manufacturer's indications or instructions, for each method and technique described above.

\subsubsection{Milk pre-treatment to reduce false positive results}

Samples testing positive in the initial residue screening $(n=200)$, were retested after the application of different milk pre-treatments to try to reduce the number of false positive results for goat milk and hence establishing the best strategy for analysis for each microbial inhibitor method. Following sample treatments were tested: heat treatment (the milk samples were put in a waterbath (Type 19 + MP thermostat, Julabo Labor-technic GmbH, Seelbach, Germany) at $80{ }^{\circ} \mathrm{C}$ for $10 \mathrm{~min}$ ); fat removal (the milk was centrifuged at 3,100 $\mathrm{g}$ for $10 \mathrm{~min}$ at $4{ }^{\circ} \mathrm{C}$ (Sigma 4K15 centrifuge, DJB Labcare Ltd, Buckinghamshire, England), followed by removal of the fat with cotton tipped applicators); and the last treatment was fat removal followed by heat-treatment. Also the same milk without any treatment was analysed to see the influence of these treatments on the test values.

\subsection{Statistical Analysis}

The differences between the reading system used for the interpretation of the microbial inhibitor tests results (visual and instrumental) were tested with McNemar's tests. The kappa statistic was used to assess the agreement if visual and instrumental reading identified the same milk sample as positive or negative in each microbial inhibitor test. A kappa value $<0.4$ indicates a poor level of agreement, 0.4 to 0.75 indicates a good agreement, and $>0.75$ indicates a high level of agreement (Fleiss, 1981). In this statistical analysis questionable results were recorded as positive results.

To evaluate the effect of each individual parameter, namely the composition, the presence of natural inhibitors and the profile of fatty acids of the goat milk on the positive results (instrumental and visual reading) in the inhibitor tests, a stepwise option of the logistic regression model was used for each group of components: 


\section{Effect of composition:}

$$
L_{i j}=\operatorname{logit}\left[P_{i}\right]=\beta_{0}+\beta_{1}[F]+\beta_{2}[P]+\beta_{3}[L]+\beta_{4}[\operatorname{logSCC}]+\beta_{5}[\log B C]+\beta_{6}[U]+\beta_{7}[F P]+\beta_{8}[p H]+\varepsilon_{i j}
$$

Where: Logit $\left[P_{i}\right]=$ probability for the positive response; $\beta_{0}=$ the intercept; $\beta_{i}=$ estimate parameters for the model; $(i=8 ;[F]=$ fat; $[P]=$ protein; $[L]=$ lactose; $[$ LogSCC $]=\log 10$ somatic cell count; $[\log B C]=\log 10$ bacterial count; $[U]=$ urea; $[F P]=$ freezing point; $\mathrm{pH}=\mathrm{pH}$ values; $\varepsilon_{\mathrm{ij}}=$ residual error.

\section{Effect of natural inhibitors:}

$$
L_{i j}=\operatorname{logit}\left[P_{i}\right]=\beta_{0}+\beta_{1}[\text { loglacto }]+\beta_{2}[\text { lyso }]+\beta_{3}[\text { lperox }]+\varepsilon_{i j}
$$

Where: Logit $\left[P_{i}\right]=$ probability for the positive response; $\beta_{0}=$ the intercept; $\beta_{i}=$ estimate parameters for the model; $(\mathrm{i}=3$; [loglacto]=log10 lactoferrin; [lyso]= lysozyme; [lperox]= lactoperoxidase; $\varepsilon_{\mathrm{ij}}=$ residual error.

\section{Effect of profile of fatty acids:}

$$
L_{i j}=\operatorname{logit}\left[P_{i}\right]=\beta_{0}+\beta_{1}[C 4: 0]+\beta_{2}[C 6: 0] \ldots \ldots \ldots .+\beta_{16}[C 18: 3]+\beta_{17}[\text { lipo }]+\beta_{18}[\text { tfa }]+\beta_{19}[\text { fatox }]+\varepsilon_{i j}
$$

Where: Logit $\left[P_{i}\right]=$ probability for the positive response; $\beta_{0}=$ the intercept; $\beta_{i}=$ estimate parameters for the model; $(\mathrm{i}=19 ;[\mathrm{C} 4: 0]=$ butyric; $[\mathrm{C} 6: 0]=$ caproic; $\ldots . .[\mathrm{C} 18: 3]=$ linolenic; [lipo]= lipolysis; $\left[\right.$ tfa $=$ total fatty acids; [fatox] = fat oxidation; $\varepsilon_{\mathrm{ij}}=$ residual error .

On the other hand, to assess the effect of the milk pre-treatment on the tests response, the Fisher's exact test was applied. Statistical analyses carried out in the present study were performed using SAS, version 9.2, 2008 (SAS Institute Inc., Cary, NC).

\section{Results and discussion}

\subsection{Test Specificity}

Table 1 shows the specificity by the visual and instrumental reading of different microbial inhibitor tests in goat milk. According to the instrumental interpretation, the specificity for BRT MRL and Eclipse 100 was higher than 95\%, obtaining a false positive rate of $4.5 \%$ and $1 \%$, respectively. In all tests the specificity calculated by visual reading was statistically $(p<0.05)$ lower compared to photometrical interpretation $(\leq 91 \%)$, except for Delvotest SP-NT MCS for which the specificity did not have statistical differences $(p>0.05)$ between both readings (94\%). 
Table 1. Specificity of different microbial inhibitor tests for the detection of antibiotics in goat milk $(n=200)$

\begin{tabular}{|c|c|c|c|c|c|c|}
\hline \multirow{2}{*}{ Microbial Tests } & \multicolumn{3}{|c|}{ Visual } & \multicolumn{2}{|c|}{ Instrumental } & \multirow{2}{*}{$\begin{array}{c}\text { p-Value } \\
\text { MNT }^{4}\end{array}$} \\
\hline & $\mathbf{P}^{1}$ & $\mathbf{Q}^{2}$ & Specificity (\%) & $\mathbf{P}^{1}$ & Specificity (\%) $)^{3}$ & \\
\hline BRT MRL & 16 & 2 & 91.0 & 5 & 97.5 & $0.0002 * * *$ \\
\hline Eclipse 100 & 16 & 5 & 89.5 & 2 & 99.0 & $<0.0001^{* * *}$ \\
\hline Delvotest SP-NT MCS & 11 & 1 & 94.0 & 12 & 94.0 & $\mathrm{p}>0.05 n s$ \\
\hline
\end{tabular}

${ }^{1} \mathrm{PR}$ : positive results; ${ }^{2} \mathrm{QR}=$ questionable results; ${ }^{3}$ Specificity (\%): negatives/total $\times 100 ;{ }^{4} \mathrm{MNT}$ : McNemar test; ${ }^{* * *}: p<0.001 ; n s: p>0.05$

These differences indicated more positive results and hence faster a penalization for a visual reading of the test results for goat milk (BRT MRL and Eclipse 100). It is important to mention that for goat milk intermediate colors (green-yellow, yellow-blue) were obtained which most of the time were classified visually as positive or doubtful, and close to the cut-off established for cow milk by kit manufactures for each microbial inhibitor test. Stead et al. (2008) in cow milk observed that the visual and scanner reading for Delvotest SP-NT in ampoules and multi-plate format gave comparable results. However, these authors also indicated that the visual assessment of samples resulting with intermediate colours (purple in a yellow background) is more difficult and such colours are often interpreted as a suspect positive result.

The number of false positive results is influenced by the incubation time or by nature of the negative controls included on each plate. After a longer incubation time less positive or doubtful results are observed and vice versa.

Despite the fact that the specificity with instrumental reading is more convenient, the visual interpretation of results in microbial inhibitor tests are prevalent used in farms (ampoule versions), dairies and laboratories which may not have the equipment and software to perform the instrumental reading.

The false positive rate indicated by Beltrán et al. (2015) who tested individual goat milk from Murciano-Granadina breed with microbial inhibitor tests was similar $(0.6-4.3 \%)$ compared also to the values found in this study for instrumental reading (1-6\%) and lower for visual interpretation (6.5-10.5\%). It is important to mention that our results are obtained for milk samples from individual animals, which present a higher variability on composition and 
quality parameters, while in control quality programmes in general bulk milk samples are analysed, which present a lower percentage of positivet results (Comunian et al., 2010).

In general, the evaluations of milk quality parameters that affect the false positive outcomes for the antibiotic screening test may provide information that can be used to improve the test performance of tests for screening milk on antimicrobials.

\subsection{Interferences of milk quality characteristics on microbial inhibitor test response}

\subsubsection{Gross composition and hygienic parameters}

Table 2 summarizes the composition and the hygienic quality of goat milk, used to assess the false positive results rate of microbial inhibitor tests. Milk samples presented a wide range of variation in milk components. The means of milk quality parameters studied are similar to those reported by Sung et al. (1999) and Park et al. (2007) for goat milk.

Table 2. Physico-chemical and hygienic-sanitary composition of individual goat milk samples $(n=110)$

\begin{tabular}{lcccc}
\hline Parameters & Mean & SD $^{1}$ & Minimum & Maximum \\
\hline Freezing Point $\left(-\mathrm{m}^{\circ} \mathrm{C}\right)$ & 0.556 & 0.010 & 0.535 & 0.582 \\
$\mathrm{pH}$ & 6.69 & 0.07 & 6.52 & 6.94 \\
Fat (\%) & 3.82 & 0.72 & 2.40 & 5.89 \\
Protein (\%) & 3.21 & 0.27 & 2.60 & 3.99 \\
Lactose (\%) & 4.49 & 2.26 & 3.73 & 5.08 \\
Urea mg/l & 40 & 9 & 30 & 70 \\
LogSCC $^{2}$ & 5.77 & 0.55 & 4.39 & 7.07 \\
LogBC $^{3}$ & 3.95 & 0.45 & 3.60 & 5.35 \\
\hline
\end{tabular}

${ }^{1}$ SD: Standard deviation; ${ }^{2}$ LogSCC: $\log _{10}$ Somatic Cell Count; ${ }^{3}$ LogBC: $\log _{10}$ Bacterial Count

The logistic regression analysis for composition and hygienic parameters showed that the predicted likelihood of a positive outcome for visual interpretation (Table 3) on BRT MRL and Eclipse 100 was associated with an increase in fat content, while for Delvotest SP-NT MCS with an increase in $\mathrm{pH}$ value (Table 3). However, for instrumental reading, the test response of BRT MRL and Eclipse 100 was unaffected by the goat milk properties analysed. 
In the case of Delvotest SP-NT MCS the increment of $\mathrm{pH}$ value was also related with the occurrence of non-compliant results by instrumental as well as for visual reading, because milk samples classified as positive were the same for both interpretations.

Along the milk composition, high concentrations of fat can adversely affect the test result of microbial inhibitor tests in cow milk, and the degree of influence is depending on of the analytical test method used (Andrew, 2000). More recently, Reybroeck and Ooghe (2012) also observed a positive relation with fat content on the false positive results in different microbial inhibitor tests (Charm Blue Yellow II, Delvotest Accelator, Delvotest T, Eclipse 50 and Eclipse 3G).

Table 3. Logistic model to predict positive results for visual interpretation of microbial inhibitor tests related with composition and quality parameters in goat milk

\begin{tabular}{|c|c|c|c|}
\hline \multirow{2}{*}{$\begin{array}{l}\text { Microbial Inhibitor } \\
\text { Tests }\end{array}$} & \multirow{2}{*}{$L=$ Logit $[P]=\beta_{0}+\beta_{1} \ldots}$. & \multicolumn{2}{|c|}{ Goodness-of-fit test } \\
\hline & & $x^{2}$ & p-value \\
\hline BRT MRL & $L=-5.9098+1.0205^{*}$ fat & 3.426 & 0.753 \\
\hline Eclipse 100 & $\mathrm{~L}=-5.8297+1.0919{ }^{*}$ fat & 3.980 & 0.678 \\
\hline Delvotest SP-NT MCS & $L=-68.4859+9.8836{ }^{*} \mathrm{pH}$ & 8.193 & 0.316 \\
\hline
\end{tabular}

The fact that high $\mathrm{pH}$ values of milk may affect the incidence of false positive results is related to the fact that in most tests acid production (indicator system) is used as criterion for bacterial growth in the microbial inhibitor tests (Reybroeck, 2010). An abnormal high pH could delay the agar color change from purple to yellow and affect the microbial inhibitor test response.

An effect of (chronic) mastitis on milk composition is the increase of the $\mathrm{pH}$ (Coulon et al., 2002, Hassan, 2013), as a consequence of reduced secretory activities of the mammary cells and an increased permeability of the mammary epithelium. This can lead to the transfer of components from blood to milk, including citrates, bicarbonates, and $\mathrm{Na}$ - and $\mathrm{Cl}$ - ions (Korhonen and Kaartinen, 1995). Higher levels of citrate and bicarbonate found during udder inflammation may be responsible for elevated pH levels (Harmon, 1994). So, milk from animals with mastitis which present a high $\mathrm{pH}$ value could contribute on the occurrence of false positive results in microbial inhibitor tests (Table 3). 


\subsubsection{Natural inhibitors}

Respect to natural inhibitors (lactoferrin, lysozyme and lactoperoxidase activity) the information in goat milk is limited, although the results presented in Table 4 are in concordance with the few studies for lactoferrin (Chen et al., 2003; Drackova et al., 2009) and lactoperoxidase activity (Zapico et al., 1991). However, the lysozyme quantity $(0.25 \mathrm{mg} / \mathrm{l})$ indicated by Chandal et al. (1968) in goat milk is difficult to relate with the value of the lysozyme activity obtained herein $(227 \mathrm{U} / \mathrm{ml})$, since the method used and the expression in units are different.

Table 4. Natural inhibitors of individual goat milk samples $(n=110)$

\begin{tabular}{lcccc}
\hline Natural inhibitors & Mean & SD $^{1}$ & Minimum & Maximum \\
\hline Lactoferrin $(\mu \mathrm{g} / \mathrm{ml})$ & 123 & 2 & 26 & 813 \\
Lysozyme $(\mathrm{U} / \mathrm{ml})$ & 227 & 94 & 61 & 477 \\
Lactoperoxidase $(\mathrm{U} / \mathrm{l})$ & 1.5 & 0.6 & 0.1 & 2.9 \\
\hline
\end{tabular}

${ }^{1} \mathrm{SD}:$ Standard deviation

Lactoferrin as a natural inhibitor present in goat milk had a significant effect in the prediction of positive outcomes only for Delvotest SP-NT MCS for both readings. A positive relation was observed, i.e. as the concentration of lactoferrin increases, the predicted likelihood to get a positive result for Delvotest SP-NT MCS is higher $(L=-9.1781+3.1907$ *[lactoferrin]). The logistic equation presented a good fit of the model $x^{2}=4.214$ and $p$-value= 0.127 .

Some authors (Carlsson and Björck, 1987; Carlsson et al., 1989; Pan et al., 2007) indicated the inhibitory effect of natural inhibitors like lactoferrin and lysozyme on microbial inhibitor tests (Geobacillus stearothermophilus var. calidolactis), moreover they also described that these inhibitory substances have a separate and a synergistic effect on the test response.

It is important to mention that the lactoferrin concentration in goat milk is related with the health status of the mammary gland, presenting higher levels of lactoferrin in mastitic milk than in normal milk (Chen et al., 2003). The lactoferrin concentrations are increased during intramammary infection possibly associated to the immune function of this protein (Auldist and Hubble, 1998). Moreover Hiss et al. (2008) studied lactoferrin concentrations in 
goat milk throughout lactation, and observed an increased concentration of lactoferrin during the colostrum phase and towards the end of the lactation.

\subsubsection{Profile of fatty acid, lipolysis and fat oxidation}

Table 5 shows the profile of fatty acids, lipolysis and fat oxidation of individual goat milk samples employed to study the interferences of milk quality characteristics on the test response. The major fatty acids (FAs) of goat milk are C10:0, C12:0, C14:0, C16:0, C18:0, and C18:1, which constitute $>75 \%$ of the FAs (Table 1). A direct comparison of the results with those from the literature is difficult because the FA content is often expressed in different units and the techniques of extraction are not the same. Moreover, the concentration of fatty acids in milk could vary by lactation period, the breed or type of diet (Carnicella et al., 2008; Sanz et al., 2007). However the most important FAs in this study are in line with the findings of other authors for goat milk (Kondyli and Katsiari, 2002; Žan et al., 2006; Park et al., 2007). It is important to remark that goat milk have more short and medium chain FAs (caproic, caprylic, capric, and lauric) than cow milk (Alonso et al., 1999) and similar than ewe milk, generally these FAs are related with the characteristic flavour of goat milk and goat milk cheeses.

The value for lipolysis indicated the good quality of milk, because the value is lower than $1.77 \mathrm{meq} / 100 \mathrm{~g}$ fat, the rate establishment in France for the payment of goat milk (Pirisi et al., 2007). Lipolysis is the most important consequence of prolonged refrigeration of milk (Vianna et al., 2012), since during cold storage natural lipases in milk or psychrotrophic microorganisms hydrolyze milk fat into small compounds (fatty acids) producing rancid and soapy flavours in dairy products. The peroxide value showed a low rate of fat oxidation (0.063 meq $\mathrm{O}^{2}-1$ fat), which are similar with the value obtained by Meshref and Rowaily (2008) and Yanhua et al. (2012) for raw cow milk (0.115 and 0.1 meq $\mathrm{O}^{2}-1$ fat, respectively).

The logistic regression analysis related with the effect of the profile of fatty acids on the test response showed that the predicted likelihood of positive outcomes for visual reading was associated with an increase of butyric acid and myristoleic acid concentration for Eclipse 100 and Delvotest SP-NT MCS, respectively (Table 6). The adjustment from the logistic equation on visual results in BRT MRL was not adequate $(p<0.05)$. 
Table 5. Profile of fatty acids, lipolysis and fat oxidation of individual goat milk samples $(\mathrm{n}=$ 110)

\begin{tabular}{|c|c|c|c|c|}
\hline Fatty acids profile $(\mathrm{g} / 100 \mathrm{ml})$ & Mean & $\mathrm{SD}^{1}$ & Minimum & Maximum \\
\hline C4:0 (butyric) & 0.089 & 0.018 & 0.058 & 0.134 \\
\hline C6:0 (caproic) & 0.072 & 0.015 & 0.045 & 0.112 \\
\hline C8:0 (caprylic) & 0.049 & 0.010 & 0.029 & 0.074 \\
\hline C10:0 (capric) & 0.128 & 0.027 & 0.075 & 0.195 \\
\hline C12:0 (lauric) & 0.177 & 0.035 & 0.112 & 0.261 \\
\hline C14:0 (myristic) & 0.534 & 0.106 & 0.354 & 0.839 \\
\hline C14:1 (myristoleic) & 0.057 & 0.009 & 0.039 & 0.078 \\
\hline C16:0 (palmitic) & 1.182 & 0.253 & 0.755 & 1.895 \\
\hline C16:1c (palmitoleic) & 0.071 & 0.013 & 0.039 & 0.107 \\
\hline C17:0 (heptadecanoic) & 0.027 & 0.005 & 0.016 & 0.042 \\
\hline C18:0 (stearic) & 0.228 & 0.084 & 0.028 & 0.451 \\
\hline C18:1 n-9 (oleic) & 0.623 & 0.134 & 0.206 & 0.991 \\
\hline C18: 2 n-6 (linoleic) & 0.058 & 0.011 & 0.036 & 0.097 \\
\hline C18:2 cis9, tras 11 (conjugated linoleic, CLA) & 0.017 & 0.004 & 0.006 & 0.031 \\
\hline C18:3 n-3 ( $\alpha$-linolenic) & 0.033 & 0.008 & 0.016 & 0.055 \\
\hline Total fatty acids & 1.554 & 2.627 & 0.000 & 13.180 \\
\hline Lipolysis (meq/100g fat) & 0.414 & 0.649 & 0.000 & 3.000 \\
\hline Fat oxidation (meq $\mathrm{O}^{2}-1$ fat) & 0.063 & 0.094 & 0.000 & 0.492 \\
\hline
\end{tabular}

${ }^{1}$ SD: Standard deviation

The instrumental test response of BRT MRL and Eclipse 100 were unaffected by fatty acids and fat characteristics present in goat milk. However, only the results of Delvotest SPNT MCS were modified by the increment of myristoleic acid $(L=-5.1376+135.5$ ${ }^{*}$ [myristoleic]) as it occurs in visual reading, sine the positive samples were the same in both readings. 
Table 6. Logistic model to predict non-compliant results for visual reading on microbial inhibitor tests related with the profile of fatty acids in goat milk

\begin{tabular}{cccc}
\hline & & \multicolumn{2}{c}{ Goodness-of-fit test } \\
\cline { 3 - 4 } Microbial Inhibitor Tests & $\mathrm{L}=$ Logit $[\mathrm{P}]=\boldsymbol{\beta}_{0}+\boldsymbol{\beta}_{1} \ldots \ldots$ & $\mathrm{X}^{2}$ & $\mathrm{p}$-value \\
\hline Eclipse 100 & $\mathrm{L}=-5.9366+46.9143^{*}$ butyric & 13.788 & 0.682 \\
Delvotest SP-NT MCS & $\mathrm{L}=-5.1376+135.5^{*}$ myristoleic & 19.857 & 0.348 \\
\hline
\end{tabular}

Information in respect to the effect of fatty acids on the inhibition of microbial inhibitor tests is limited. Only Mäyrä-Mäkinen (1990) and Carlsson and Björk (1992) suggested that a high concentration of fatty acids in cow milk could interfere on the test response. Also Barbosa (1997) indicated in a report about the occurrence of antibiotics in ewes' and goat milk that a high level of butyric and capric acid in goat milk was responsible for positive results when no antibiotic was present. This result cited by Barbosa (1997) is in line with our visual results for Eclipse 100, which showed the inhibitory effect of butyric acid on the response of microbial inhibitor tests. However, Altahus et al. (2003) did not observed any influence of the fatty acids in ewes' milk in the response of BRT and Delvotest.

Some fatty acids have an antibacterial activity, which is influenced by their structure and shape (Andrew et al., 2010), being more active against Gram-positive bacteria than against Gram-negatives (Galbraith et al., 1971). Kabara et al. (1972) studied the effect of fifteen fatty acids, including myristoleic acid, on nine Gram-positive microorganisms and on Candida. These authors observed that myristoleic acid had an inhibitory effect to all microorganisms employed, and also indicated that unsaturated fatty acids tend to have greater potency than saturated fatty acids with the same length of the carbon chain. Feldlaufer et al. (1993) also reported the antibacterial effect of myristoleic acid on Grampositive bacteria. Therefore, as Geobacillus stearothermophilus var. cadilodactis (the test microorganism mostly used in microbial inhibitor tests) is Gram-positive, its response could be affected by the presence of this fatty acid.

\subsection{Effect of milk pre-treatment on the test response}

All milk samples testing positive (instrumental reading) in the initial residue screening, were retested the next day without any treatment and after the application of three different milk pre-treatments (heat treatment, fat removal and fat removal followed by heat-treatment) 
to try to reduce the number of false positive results for goat milk, and these results are shown in Table 7.

Table 7. Results in different microbial inhibitor tests for positive goat milk samples before and after special sample treatment.

\section{Pre-Treatments}

\begin{tabular}{|c|c|c|c|c|c|c|c|c|c|}
\hline \multirow[t]{2}{*}{ Microbial Tests } & \multirow[t]{2}{*}{$\mathrm{n}^{1}$} & \multicolumn{2}{|c|}{ No treatment } & \multicolumn{2}{|c|}{ Heat treatment } & \multicolumn{2}{|c|}{ Fat removal } & \multicolumn{2}{|c|}{ Fat + Heat } \\
\hline & & $\mathrm{N}^{2}$ & $\mathrm{P}^{3}$ & $\mathrm{~N}^{2}$ & $\mathrm{P}^{3}$ & $\mathrm{~N}^{2}$ & $\mathrm{P}^{3}$ & $\mathrm{~N}^{2}$ & $\mathrm{P}^{3}$ \\
\hline BRT MRL & 5 & - & 5 & - & 5 & - & 5 & - & 5 \\
\hline Eclipse 100 & 2 & - & 2 & 2 & - & 1 & 1 & 2 & - \\
\hline Delvotest SP-NT MCS & 12 & 3 & 9 & 5 & 7 & 7 & 5 & 8 & 4 \\
\hline
\end{tabular}

${ }^{1} \mathrm{n}$ : positive samples on the initial residue screening

${ }^{2} \mathrm{~N}$ : Negative result

${ }^{3} \mathrm{P}$ : Positive result

The retesting of positive samples after one day without any milk pre-treatment did not modify the number of outcomes on microbial inhibitor tests, except in Delvotest SP-NT MCS, with a decrease from 12 to 9 .

The microbial inhibitor test which was not influenced by milk pre-treatment was the BRT MRL. However, in Eclipse 100 all milk pre-treatments reduced the number of false positive outcomes, although the number of samples is very small. For Delvotest SP-NT MCS the most effective procedure was fat removal followed by heat-treatment (decrease from 9 to 4), followed by fat removal which decreased significantly the positive results from 9 to 5 $(p=0.049)$.

The fact that for Delvotest SP-NT MCS the heat-treatment reduced slightly the number of false positive outcomes (decrease from 9 to 7) could be explained, because these positive results may be associated with the lactoferrin parameter. The entire activity of lactoferrin in milk is inactivated at $85^{\circ} \mathrm{C}$ for 30 min (El-Agamy, 2000). At the present study the heat treatment carried out was shorter and at a lower temperature, so that could explain the remaining number of false positive results. On the other hand, it seems logical that the fat removal was more effective because at the same time part of the inhibitory fatty acids are removed.

Some authors testing cow, ewe and goat milk have suggested the use of heat treatment to diminish the false positive results on microbial inhibitors tests, although they 
used different temperatures and times of heating (82 ${ }^{\circ} \mathrm{C}$ for 5 min (Oliver et al., 1984; Kang and Kondo, 2005) and $82 \stackrel{\circ}{\circ}$ for 10 min (Molina et al., 1999; Molina et al., 2003)).

From the results the most effective sample pre-treatment for microbial inhibitor analysis methods could be used in order to reduce the number of false positive results for goat milk. Besides, all quality milk laboratories generally have the equipment necessary to apply the procedure, which is simple, easy to be performed and inexpensive. With the implementation of such a sample pre-treatment the specificity for goat milk of all microbial inhibitor tests was > 95\% (BRT MRL: 95.5\%; Eclipse 100: 100\% and Delvotest SP-NT MCS $96.4 \%)$.

\section{Conclusions}

For all three microbial inhibitor tests (BRT MRL, Delvotest SP-NT MCS and Eclipse ) false positive results were obtained when testing raw goat milk. The specificity of the tests improved if appropriate equipment as instrumental readers were used for the interpretation of test results compared to the results obtained by visual reading. This is caused by the fact that for goat milk usually intermediate colors of the test agar at the end of the incubation are obtained. In this way the testing of residue-free goat milk samples could result in a penalty contributed to the milk producer.

The parameters associated with the predicted likelihood of false positive outcomes by instrumental and visual reading were different. The increment of false positive results for visual interpretation was associated for BRT MRL with an increased fat content, for Eclipse 100 with a high concentration of fat and butyric acid, and finally for the Delvotest SP-NT MCS the outcomes were related with elevated $\mathrm{pH}$ values, or high lactoferrin and myristoleic acid concentrations. However, for instrumental reading the logistic regression analysis showed that BRT MRL and Eclipse 100 were unaffected by the parameters studied. While in Delvotest SP-NT MCS the false outcomes were related with some milk properties as the $\mathrm{pH}$ values, lactoferrin and myristoleic acid, as well as the visual reading.

The most effective milk pre-treatment for microbial inhibitor tests to reduce the number of false positive results when testing goat milk was the fat removal followed by heattreatment. These pre-treatments can be included as a routine in the standard operating procedures of the monitoring laboratories in order to decrease the number of false positive results, and thus avoiding a problem for goat milk producers and dairy industries. 


\section{Acknowledgements}

This work has been realized through the grant EEBB-I-13-06255 financed by the Ministry of Science and Innovation (Madrid, Spain) allowing Tamara Romero perform a predoctoral stay at ILVO (Institute for Agricultural and Fisheries Research) in Belgium. The authors are grateful to the companies of screening tests for their technological support. Also, the authors thank MCC-Vlaanderen and Comité du Lait for the assistance with milk quality and composition analysis and appreciate the cooperation of the commercial dairy goats' farms.

\section{References}

Adetunji, V.O. 2011. Effects of processing on antibiotic residues (streptomycin, penicillin-G and tetraciclyne) in soft cheese and yoghurt processing lines. Pak. J. Nutr. 10: 792-795.

Alanis, A.J. 2005. Resistance to antibiotics: are we in the post-antibiotic era?. Arch. Med. Res. 36: 697-705.

Alonso, L., Fontecha, J., Lozada, L., Fraga, M.J., Juárez, M. 199. Fatty acid composition of caprine milk: major, branched chain and trans fatty acids. J. Dairy Sci. 82: 878-884.

Althaus, R.L., Torres, A., Torres, A., Peris, C., Beltrán, M.C., Fernández, N., Molina, M.P. 2003. Accuracy of BRT and Delvotest microbial inhibition tests as affected by composition of ewe's milk. J. Food Protect. 66: 473-478.

Andrew, S.M. 2000. Effect of fat and protein content of milk from individual cows on the specificity rates of antibiotic residue screening tests. J. Dairy. Sci. 83: 2992-997.

Andrew, S.M. 2001. Effect of composition of colostrum and transition milk from Holstein heifers on specificity rates of antibiotic residue tests. J. Dairy Sci. 84: 100-106.

Andrew, S.M., Frobish, R.A., Paape, M.J., Maturin, L.J. 1977. Evaluation of selected antibioticresidue screening tests for milk from individual cows and examination of factors the effect the probability of false-positive outcomes. J. Dairy Sci. 80: 3050-3057.

Andrew, P.D., Smith, V.J. 2010. Antibacterial free fatty acids: activities, mechanisms of action and biotechnological potencial. Appl. Microbiolo. Biotechnol. 85: 1629-1642.

AOAC, 1997. Peroxide values of oils and fats. AOAC Official method 965.93. Chapter 41, 9B.

Auldist, M.J., Hubble, I.B. 1998. Effects of mastitis on raw milk and dairy products. The Aust. J. Dairy Technol. 53: 28-36. 
Barbosa, M. 1997. Occurrence of antibiotics in ewe and goat milk. Application and suitability of various test kits. Anex IV. Report. Analytical Week. Lisboa, Portugal.

Beltrán, M.C., Berruga, M.I., Molina, A., Althaus, R.L., Molina M.P. 2015. Performance of the current microbial tests for screening antibiotic in sheep and goat milk. Int. Dairy J. 41: 1315.

Berruga, M.I., Beltrán, M.C., Novés, B., Molina, A., Molina, M.P. 2011. Effect of penicillins on the acidification of yogurt made from ewe's milk during the storage. pp. 145-149. A. Mendez-Vilas (Eds.), Science and Technology Against Microbial Pathogens. Research, Development and Evaluation, World Scientific Publishing. Hackensack, NJ.

Buswell, J.F., Knight, C.H., Barber, D.M.L. 1989. Antibiotic persistence and tolerance in the lactating goat following intramammary therapy. Vet. Rec. 125: 301-303.

Carcinella, D., Dario, M., Ayres, M.C.C., Laudadio, V., Dario, C. 2008. The effect of diet, parity, year and number of kids on milk yield and milk composition in Maltese goat. Small Rumin. Res. 77: 71-74.

Carlsson, Å., Björk, L. 1987. The effect of some indigenous antibacterial factors in milk on the growth of Bacillus stearothermophilus var. calidolactis. Milchwissenschaft. 42: 283285.

Carlsson, Å., Björk, L. 1992. Liquid chromatography verification of tetraciclyne residues in milk and infkuence of milk fat lipolysis on the detection of antibiotic residues by microbial assays and the Charm II test. J. Food. Prot. 55: 374-378.

Carlsson, Å., Björk, L., Persson, K. 1989. Lactoferrin and lysozyme in milk during acute mastitis and their inhibitory effect in Delvotest P. J. Dairy Sci. 72: 3166-3175.

Chandan, R.C., Parry, R.M., Shahani, K.M. 1968. Lysozyme, lipase, and ribonuclease in milk of various species. J. Dairy Sci.51: 606-607.

Chen, P.W., Chen, W. C., Mao, F.C. 2003. Increase of lactoferrin concentration in mastitic goat milk. J. Vet. Med. Sci. 66: 345-350.

Commission Decision 2002/657/EC of 12 August 2002 implementing Council Directive 96/23/EC concerning the performance of analytical methods and the interpretation of results. Off. J. Eur. Comm L221: 8-36.

Commission Regulation (EU) No 37/2010 of 22 Dicember 2010. On pharmacologically active substances and their classification regarding maximum residue limits in foodstuffs of animal origin. Off. J. Eur. Union L15: 1-72. 
Comunian, R., Paba, A., Dupre, I., Daga, E.S., Scintu, M.F. 2010. Evaluation of a microbiological indicator test for antibiotic detection in ewe and goat milk. J. Dairy Sci. 93: 5644-5650.

Coulon, J.B., Gasqui, P., Barnouin, J., Ollier, A., Pradel, P., Pomiès, D. 2002. Effect of mastitis and related-germ on milk yield and composition during naturally-occurring udder infections in dairy cows. Anim Res. 51: 383-393.

Council Directive 96/23/EC of 29 April 1996 on measures to monitor certain substances and residues thereof in live animals and animal products and repealing Directives 85/358/ECC and 86/469/ECC and Decisions 89/187/ECC and 91/664/ECC. Off. J. Eur. Union L125: 10-32.

Crosson, C., Thomeas, D., Rossi, C. 2010. Quantification of immunoglobulin G in bovine and caprine milk using a surface plasmon resonance-based immunosensor. J. Agr. Food Chem. 58: 3259-3264.

Daeseleire, E., De Ruyck, H., Van Renterghem, R. 2000. Confirmatory assay for the simultaneous detection of penicillins and cephalosporins in milk using liquid chromatography/tandem mass spectrometry. Rapid Commun. Mass Spectrom.14: 14041409.

Demoly, P., Romano, A. 2005. Update on beta-lactam allergy diagnosis. Curr. Allergy Asthm. R. 5: 9-14.

Dračková, M., Borkovcová, I., Janštová, B., Naiserová, M., Přidalová, H., Navrátilová, P., Vorlová, L. 2009. Determination of lactoferrin in goat milk by HPLC method. Czech J. Food Sci. 27: 102-104.

El-Agamy, E.I. 2000. Effect of heat treatment on camel milk proteins with respect to antimicrobial factors: a comparison with cows' and buffalo milk proteins. Food Chem. 68: 227-232.

Feldlaufer, M.F., Knox, D.A., Lusby, W.R., Shimanuki, H. 1993. Antimicrobial activity of fatty acids against Bacillus larvae, the causative agent of America foulbrood disease. Apidologie. 24: 95-99.

Ferrini, M.A., Trenta, S. Mannoni, S., Rosati, R., Coni, E. 2010. Depletion of long-acting ampicillin in goat milk following intramuscular administration. J. Agri. Food. Chem. 58: 12199-12203. 
Galbraith, H., Miller, T.B., Paton, A.M., Thompson, J.K. 1971. Antibacterail activity of long chain fatty acids and the reversal with calcium, magnesium, ergocalciferol and cholesterol. J. Appl. Bacteriol. 34: 803-813.

Halbert, R.W., Erskine, R.J., Bartlett, P.C., Johnson, G.L. 1996. Incidence of false-positive results for assays used to detect antibiotics in milk. J. Food Prot. 59: 886-888.

Harmon, R.J. 1994. Physiology of mastitis and factors affecting somatic cell counts. J. Dairy Sci. 77: 2103-2112.

Hassan, H.J. 2013. Variations in milk composition of some farm animals resulted by subclinical mastitis in Aldiwania province. Bas. J. Vet. Res. 12: 17-24.

Hiss, S., Meyer, T., Sauerwein, H. 2008. Lactoferrin concentrations in goat milk throughout lactation. Small Rumin. Res. 80: 87-90.

IDF. 2010. New applications of mid infra-red Spectrometry for the analysis of milk and milk products. Bulletin of the IDF No 447: 2010. International Dairy Federation, Brussels, Belgium.

IDF. 2011. Milk determination of the lactoperoxidase activity. Photometric method (Reference method). IDF/RM Standard 208: 2011. International Dairy Federation, Brussels, Belgium.

Kabara, J.J., Swieczkwoski, D.M., Conley, A.J., Truant, J.P. 1972. Fatty acids and derivatives as antimicrobial agents. Antimicrob. Agents Chemother. 2: 23-28.

Kang, J.H., Jin, J.H., Kondo, F. 2005. False-positive outcome and drug residue in milk samples over withdrawal times. J. Dairy Sci. 88: 908-913.

Karzis, J., Donkin, E.F., Petzer, I.M. 2007. Withdrawal periods and tissue tolerance after intramammary antibiotic treatment of dairy goats with clinical mastitis. Onderstepoort $\mathrm{J}$. Vet. Res. 74: 281-288.

Korhonen, H., Kaartinen, L. 1995. Changes in the composition of milk induced by mastitis. pp 76-82. In: The bovine udder and mastitis. Sandholm M., Honkanen-Buzalski T., Kaartinen L., Pyörälä S. University of Helsinki, Faculty of Veterinary Medicine, Helsinki, Finland.

Mäyrä-Mäkinen A. 1990. T-101 test for antibiotic residues in milk. Scand. Dairy Inf. 2: 38-39.

Meshref, A.A. 2008. Effect of heating treatments, processing methods and refrigerated storage of milk and some dairy products on lipids oxidation. Pak. J. Nutr. 7: 118-125. 
Molina, M.P., Segura, C., Luján, A., Althaus, R.L., Peris, C. 1999. Influencia del calentamiento y del tiempo de incubación sobre la respuesta del método BRT en la leche de cabra. Ile, Revista Mensual de las Industrias Lácteas Españolas. 241: 37-40.

Molina, M.P., Althaus, R.L., Balasch, S., Torres, A., Peris, C., Fernandez, N. 2003. Evaluation of screening test for detection of antimicrobial residues in ewe milk. J. Dairy Sci. 86: 1947-1952.

Oliver, S.P., Duby, R.T., Prange, R. W., Tritschler, J. P. 1984. Residues in colostrum following antibiotic dry cow therapy. J. Dairy Sci. 67: 3081-3084.

Paape, M.J., Wiggans, G.R., Bannerman, D.D., Thomas, D.L., Sanders, A.H., Contreras, A., Moroni, P., Miles, R.H. 2007. Monitoring goat and sheep milk somatic cell counts. Small Rumin. Res. 68: 114-125.

Packham, W., Broome, M.C., Limsowtin, G.K.Y., Roginski, H. 2001. Limitations of standard antibiotic screening assays when applied to milk for cheesemaking. Aust. J. Dairy Technol. 56: 15-18.

Pan, Y., Rowney, M., Guo, P., Hobman, P. 2007. Biological properties of lactoferrin: an overview. Aus. J. Dairy Assoc. 39: 97-101.

Park, Y.W., Juárez, M., Ramos, M., Haenlein, G.F.W. 2007. Physico-chemical characteristics of goat and sheep milk. Small Rumin. Res. 68: 88-113.

Pirisi, A., Lauret, A., Dubuef, J.P. 2007. Basic and incentive payments for goat and sheeo milk in relation to quality. Small Rumin. Res. 68: 167-178.

Regulation (EC) No 853/2004 of the European Parliament and of the Council of 29 April 2004 laying down specific hygiene rules for on the hygiene of foodstuffs. Off. J. Eur. Comm L139: 55-205.

Regulation (EC) No 470/2009 of the European Parliament and of the Council of 6 May 2009 laying down Community procedures for the establishment of residue limits of pharmacologically active substances in foodstuffs of animal origin, repealing Council Regulation (EEC) No 2337/90 and amending Directive 2001/82/EC of the European Parliament and of the Council and Regulation (EC) No 726/2004 of the Euripean Parliament and of the Council laying down a Community procedure for the establishment of maximum residue limits of veterinary medicinal products in foodstuffs of animal origin. Off. J. Eur. Comm L152: 11-22. 
Reybroeck, W. 2010. Screening for residues of antibiotics and chemotherapeutics in milk and honey. pp 295. Ph. D. Ghent University. Belgium.

Reybroeck, W., Ooghe, S. 2012. FASC acceptance criteria for microbiological inhibitor tests: fulliment by new tests. pp 197-201. In: Schilt R. Procedings of the EuroResidue VII conference on residues of veterinary drugs in food. Egmond aan Zee, the Netherlands.

Reybroeck, W., De Vleeschouwer, M., Marchand, S., Sinnaeve, D., Heylen, K., De Block, J., Madder, A., $\quad$ Martins, J., $\quad$ Heyndrickx, Marc. 2014. PLOS ONE. Cyclic lipodepsipeptides produced by Pseudomonas spp. naturally present in raw milk induce inhibitory effects on microbiological inhibitor assays for antibiotic residue screening. PLoS ONE 9(5): e98266. doi:10.1371/journal.pone.0098266.

Romnée, J.M., Raskin, P., Istasse, L., Laloux, J., Guyot, A. 1999. Incidence de facteurs alimentaires sur l"obtention de résultats faux positifs lors de la détection des antibiotiquesb dans le lait per la méthode Delvotest $\mathrm{SP}^{\circledR}$. Le Lait. 79: 341-346.

Sanders, P., Bousquet-Melou, A., Chauvin, C., Toutain, P.L. 2011. Utilisation des antibiotiques en élevage et enjeux de santé publique (Use of antibiotics in animal and public health issues). INRA Prod. Anim. 24: 199-204.

Sanz Pelayo, M.R., Chillard, Y., Schidely, P.H., Boza, J. 2007. Influence of type of diet on the fat constituyents of goat and sheep milk. Small Rumin. Res. 68: 42-63.

Silanikove, N., Leitner, G., Merin, U., Prosser, C.G. 2010. Recent advances in exploiting goat's milk: Quality, safety and production aspects. Small Rumin. Res. 89: 110-124.

Stead, S.L., Ashwin, H., Richmond, S.F., Sharman, M., Langeveld P.C., Barendse, J.P., Stark, J., Keely, B.J. 2008. Evaluation and validation according to international standards of the Delvotest SP-NT screening assay for antimicrobial drugs in milk. Int. Dairy J. 18: 311.

Strzałkowska, N., Jóźwik, A., Bagnicka, E., Krzyżewski, J., Horbańczuk, K., Pyzel, B., Horbańczuk, J.O. 2009. Chemical composition, physical traits and fatty acid profile of goat milk as related to the stage of lactation. Anim. Sci. Pap. Rep. 27: 311-320.

Sung, Y.Y., Wu, T.I., Wang, P.H. 1999. Evaluation of Milk quality of Alpine, Nubian, Saanen and Toggenburg breeds in Taiwan. Small Rumin. Res. 33: 17-23.

Vianna, P.C.B., Walter, E.H.M., Dias, M.E.F., Faria, J.A.F., Netto, F.M., Gigante, M.L. 2012. Effect of addition of $\mathrm{CO}_{2}$ to raw milk on quality of UHT-treatred milk. J. Dairy Sci. 95: 4256-4262 
Yanhua, L., Lanwei, Z., Weijun, W. 2012. Formation of aldehyde and ketone compounds during production and storage of milk powder. Molecules. 17: 9900-9911.

Žan, M., Stibil, J.V., Rogel, J. I. 2006. Milk fatty acid composition of goats grazing on alpine pasture. Small Rumin. Res. 64: 45-52.

Zapico, P., Gaya, P., Nunez, M., Medina, M., De-Paz, M. 1991. Influence of breed, animal and days of lactation on lactoperoxidase system components in goat milk. J. Dairy Sci. 74: 783-787. 



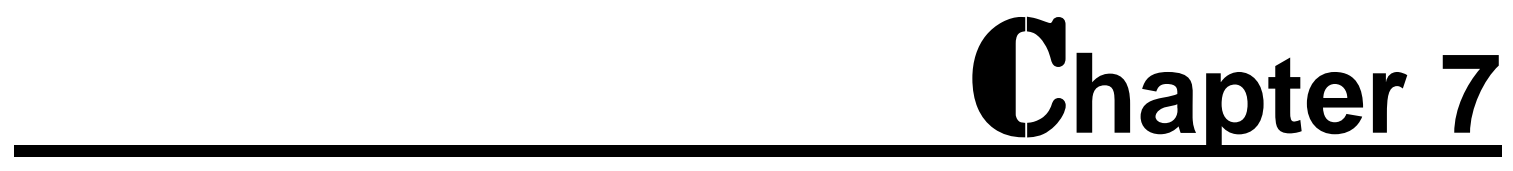

General discussion 



\section{General discussion}

The use of veterinary drugs, especially antibiotics, is a widespread practice in the treatment and prophylaxis of diseases in dairy livestock. The prudent use of medicinal products is necessary to ensure the food safety of dairy products and also to manage the potential risk of antimicrobial resistance in animals. An improper drug treatment in dairy animals can result in residues in milk above Maximum Residue Limit (MRL) fixed in Commission Regulation (EU) No 37/2010. Therefore, to avoid the presence of residues in milk the implementation of a good dairy farming practice is essential to ensure that the milk is produced by healthy animals respecting the animal welfare, social, economic, and environmental perspectives (FAO and IDF, 2011).

The presence of antibiotics in milk can cause serious public health problems such as allergies, digestive problems, antibiotic resistances or direct toxic effects, among others (Demoly and Romano, 2005; Trobos et al., 2009; Sanders et al., 2011). The presence of antimicrobials can also have negative repercussions on the technological properties of the milk as they can inhibit fermentation procedures required to make cheese or yoghurt (Packham et al., 2001). Goat milk is basically destined for the elaboration of fermented products, and antibiotics in milk can thus affect the production process and compromise the consumers' safety if still present in the final product (Oliver et al., 2011).

To protect consumers an integrated system for antibiotics control in milk with shared responsibilities for farmers, processors, and food inspection is employed. The control program is usually performed in two steps, a primary screening to detect the potential non-compliant samples and secondly a confirmatory analysis of the suspect samples to identify the molecule present in the sample and to quantitate the residue, if necessary (Commission Decision (EC) 657/2002). Non-compliant samples containing residues of allowed substances above the tolerated concentration (MRL) or containing residues of prohibited substances are taken out of the market.

Qualitative methods are used for screening to detect antibiotic residues in milk, being microbial inhibitor tests the most frequently used in control laboratories as they are relatively inexpensive, user-friendly and able to detect a great variety of substances with a high sample throughput. These tests are generally based on the inhibition of the growth of the microorganism Geobacillus stearothermophilus var. calidolactis. One of the main drawbacks of microbial screening tests is that they are non-specific for antimicrobials, and may be affected by any substance or compound capable to inhibit the growth of the test organism and hence causing false positive results. 
The legislation does not mention a maximum percentage of false positive results accepted for screening tests although only a small number is preferred by the users as the occurrence of positive outcomes in regulatory quality programs of milk can generate serious consequences as economic problems for farmers, because good milk could be discarded or extra costs could be involved for confirmatory tests.

Some studies have been carried out in cow and sheep milk to evaluate the effect of the milk composition and the presence of contaminants in milk on the occurrence of false positive results in microbial inhibitor tests. However, in goat milk, related studies are very limited.

The aim of this thesis was to study the presence of different contaminants in goat milk derived from farming practices, as well as the characteristics of the milk itself on the results of the BRT MRL, Delvotest SP-NT MCS, and Eclipse 100, all microbial inhibitor tests used in routine for screening for antibiotics.

First, the suitability of microbial inhibitor tests for screening antibiotic residues in goat colostrum was evaluated. Colostrum is considered a product of animal origin produced in a similar way as raw milk and therefore, it is subject to official hygiene requirements established by legislation, in which the monitoring for antibiotic residues is included (Regulation (EC) No 853/2004).

Antibiotics given intramammary in dry-off therapy to treat mastitis and reduce the number of new infections (Fox et al., 1992; Lohuis et al., 1995) are among the possible causes for the presence of antibiotics in colostrum and milk after partum.

The results presented in this thesis (Chapter 3 ) showed that none of the microbial inhibitor tests was suitable for the analysis of antibiotic residues in goat colostrum as they presented high rates of doubtful and positive results ranging 46.5 to $86 \%$ in the first 24 hours post-partum. Atypical colourations in these tests and hence doubtful results are often observed. Also a dull film on top of the microwells appears frequently, likely due to the high concentration of colostrum components, which may imply a poor diffusion of the samples in the agar and complicate a correct interpretation of the test results.

The occurrence of false positive results was mainly related to high protein content in colostrum samples and gradually decreases as days progressed. Goat colostrum is characterised by a protein content higher than milk (Argüello et al., 2006; Romero et al., 2013). Also, colostrum contains high concentrations of proteins such as immunoglobulins, lactoferrin, and lysozyme (Hiss et al., 2008) with a known inhibitory effect on the Geobacillus stearothermophilus var. calidolactis metabolism (Carlsson and Björck, 1987; Carlsson et al., 1989). 
Egan et al. (1984) analysed bovine colostrum of the first milking by disc assays based on the inhibition of Geobacillus stearothermophilus var. calidolactis, and they obtained a higher specificity $(76.3 \%)$ than the one calculated in this thesis for caprine colostrum. Also Andrew (2001), analysing bovine colostrum and transition milk samples by the Delvotest SP, found a greater specificity for colostrum (88\%). However, for transition milk samples, the specificity value was lower (92\%) than the one obtained herein. The results obtained in Chapter 3 indicated that only the Delvotest SP-NT MCS could be used for the analysis of transition milk from goats (secretions between 48-96 hours post-partum) presenting an elevated specificity (98-100\%).

In caprine livestock specialised in milk production, the artificial rearing of goat kids and milking goats immediately after partum is a common practice (Argüello et al., 2004). It is important to remark, that milk containing colostrum may occur more frequently if the reproduction management is performed in groups, since a large number of animals would be in the same stage of lactation. This habitual practice can cause the presence of colostrum in the milk supply if not properly performed.

The addition of colostrum obtained from different times post-partum to goat milk was also studied to calculate the inhibitory concentrations producing $5 \%$ of positive results in microbial inhibitor tests. The highest interference were obtained for the addition of colostrum from 12 to 24 hours post-partum and the inhibitory concentrations (5\% inhibition) were ranging from 5.2 to $34.2 \%$; being the $B R T M R L$ the most affected, even when colostrum from 48 hours post-partum is present in the milk.

Other farming practice that could cause the presence of residues in the milk is the cleaning and disinfecting of the milking equipment and milk storage tanks at farms. The hygienic production of milk implies the use of cleaning products to prevent the proliferation of microorganisms on surfaces that come into direct contact with milk (Pontefract, 1991). Following good cleaning practices, the residues of detergents in milk should be minimal $(<2$ $\mathrm{mg} / \mathrm{kg}$; Reybroeck, 1997), although owing to errors in the dosage and inadequate postrinsing, residues of these cleaning products could be present in higher concentrations, which may alter the organoleptic characteristics of the milk (Dunsmore et al., 1985; Merin et al., 1985 ) and interfere in the activity of starter cultures used by the dairy industry (Guirguis and Hickey, 1987; Petrova and Dimitrov, 1993).

In general alkaline (hydroxides and carbonates) and acid (nitric and phosphoric) detergents are usually employed in automated processes to clean milking equipment and milk storage tanks at farms. However, in small-sized farms and dairies, automated cleaning 
processes are hardly found (Reinemann et al., 2003) and many cleaning operations are carried out manually using often non-recommended products (i.e. detergents for home use).

The effect of cleaning products on the performance of microbial inhibitor tests has been studied by few authors in cow milk presenting controversial results. Žvirdauskiene and Salomskiene (2007) and Salomskiene et al. (2013) found false positive results at alkaline detergent concentrations equivalent to the dose recommended by the manufactures and above. Also, these authors did not find interferences due to the presence of acid detergents in milk. At lower alkaline detergent concentrations $(\leq 1,000 \mathrm{mg} / \mathrm{l})$, Merin et al. (1985) and Salomskiene et al. (2013) did not find any positive results for the Delvotest microbial test. However, Schiffmann et al. (1992) observed doubtful and positive results at very low concentrations $(0.01 \mathrm{mg} / \mathrm{ml})$ of acid and basic detergent in different versions of the BRT test.

With respect to disinfectants products, Merin et al. (1985) indicate positive results in the Delvotest using bovine milk spiked with sodium hypochlorite at a high concentration (25 $\mathrm{mg} / \mathrm{l})$. There is no information about the effect of detergents for home use on the responses of microbial inhibitor screening tests.

The results related with the effect of the presence of cleaning products in goat milk on the microbial inhibitor test response (Chapter 4) showed that the presence in goat milk of acid detergents and disinfectants based on sodium hypochlorite did not affect the response of BRT MRL, Delvotest SP-NT MCS, and Eclipse 100 tests (100\% negative results). However, alkaline detergents at concentrations $\geq 1 \mathrm{ml} / \mathrm{l}$ could lead to false positive results in microbial inhibitor tests, and from $4 \mathrm{ml} / \mathrm{l}$ on the results were $100 \%$ positive for most detergents studied. Regarding to the cleaning products for home use, the washing-up liquid containing sodium laureth sulphate and ethanol had a greater effect on the microbial inhibitor tests considered, even at a relatively low assay concentration $(1 \mathrm{ml} / \mathrm{l})$. The positive results obtained can be explained by the component ethanol, considered as an antimicrobial substance (Oh and Marshall, 1993). Any tested concentration of the disinfectant sodium hypochlorite in goat milk altered the inhibitor test response.

Another important aspect related to the presence of residues of cleaning products in milk is its possible effect on the detection capability of the microbial screening tests. The results herein showed that the presence in goat milk of alkaline, acid, and washing-up liquid detergents at concentration of $0.5 \mathrm{ml} / /$ slightly hampered the detection capability of the microbial inhibitor test for penicillins, however, the detection of these drugs at safe levels (MRLs) was not compromised (detection capability < MRLs). 
Residues of antiparasitic agents in goat milk from veterinary treatments in animals in lactation could also affect the response of microbial tests for screening for antibiotics. In fact, positive outcomes (1\%) in microbial inhibitor tests have been related by Fabre et al. (1995) to antiparasitic treatments in dairy cows.

The use of antiparasitic substances in the treatment and prevention of parasitic diseases in dairy goats is necessary to ensure the profitability of farms, since parasites usually cause negative effects in dairy livestock (Fthenakis et al., 2000; Walton and Currie, 2007). It should be noted that many antiparasitic drugs are not approved for use in goats (González-Canga et al., 2012). Moreover, there are only a limited number of antiparasitic products licensed to treat goats during the lactation period. Therefore, medicinal products available for major species like cows or sheeps are often employed in goats under cascade prescription.

In the European Union, Directives (EC) No 82/2011 and 28/2004, permit Member States, in exceptional circumstances, to allow the off-label use of veterinary products under cascade; the veterinarian being the responsible for the proper administration in order to ensure food safety. However, the off-label application of antiparasitic agents in lactating dairy goats could suppose a risk for the consumer's safety due to the possible presence of antiparasitic drug residues in the milk supply.

In Chapter 5 the effect of residues of antiparasitic agents in milk on the occurrence of false positive results in microbial screening tests was investigated. For this, an in vitro study to evaluate the effect of seven parasiticides commonly used in dairy goats, and two studies, in which albendazole and ivermectin were applied to two groups of dairy goats in lactation were carried out.

The in vitro presence of antiparasitic substances (albendazole, closantel, diclazuril, febendazole, levamisole, diazinon, and ivermectin) in goat milk, does not seem to be the cause of false positive results in microbial inhibitor tests, since the inhibitory concentrations calculated producing 5,10 and $50 \%$ of positive results were much higher than the residual amounts of parasiticides in milk, indicated by some authors after veterinary treatments (Waldhalm et al., 1989; Scott el al., 1990; Cinquina et al., 1997). Closantel was the only antiparasitic drug that could interfere with the response of the BRT MRL test, since the inhibitory concentration producing $5 \%$ of positive results $(1 \mu \mathrm{g} / \mathrm{ml})$ was close to the concentration estimated by Lezzi et al. (2014) in goat milk after drug administration ( $0.8 \pm 0.3$ $\mu \mathrm{g} / \mathrm{ml})$. 
The depletion of some antiparasitic substances in goat milk is unknown, especially when veterinary drugs are applied as off-label treatments which could result in higher excreted levels of these substances in goat milk. Another aspect that could also affect the performance of microbiological tests is the metabolism of these substances in the animal, producing different metabolites in goat milk that could present a greater ability to interfere with the growth of the test microorganism than the pattern drugs used in the in vitro study.

Actually, among the internal parasitic diseases more frequently found in lactating goats are the gastrointestinal nematodes. Albendazole is effective for the prevention and control of nematode infestations (Campbell, 1990). Moreover, it is readily absorbed by the gut, and following this absorption, albendazole is metabolised (Danaher et al., 2007) by rapid pass oxidation of its sulphide group to form albendazole sulphoxide (ABZSO), with further oxidation to form albendazole sulphone $\left(\mathrm{ABZSO}_{2}\right)$ and deacetylation of the carbamate group to form albendazole 2-aminosulphone $\left(\mathrm{NH}_{2}-\mathrm{ABZSO}_{2}\right)$. A Maximum Residue Limit (MRL) for the sum of albendazole and its metabolites has been fixed at $100 \mu \mathrm{g} / \mathrm{kg}$ in raw milk (Commission Regulation (EU) No 37/2010).

The effect of albendazole and its metabolites in goat milk on the response of microbial tests was assessed. Due to the limited number of available commercial antiparasitic agents for use in goats, the animals were treated with a commercial ovine formulation (Ovidax, $2.5 \%$ of albendazole). Albendazole and its metabolite residues in goat milk after under cascade treatment were not detected above MRL from the third day post-administration. However, a high percentage of positive results were obtained only for the BRT MRL test during the first six days after treatment, even when no longer albendazole metabolites were present.

For instance levamisole, a drug belonging to the benzimidazole (anthelmintics) family, being active against various parasites (cestodes, trematodes and nematodes), acts unspecific, restoring the cellular and humoral immune response in animals (Sajid et al., 2006). In bovine, levamisole stimulates the differentiation of $T$ lymphocytes and their response to antigens; it also increases the activity of macrophages and neutrophils (Tizard, 2009). In addition, interferences on the microbial inhibitor test response might also be related to the stress produced in goats by the treatment. In dairy livestock, stress has been associated to changes in some physiological and biochemical indicators in blood (Trevisi and Bertoni, 2009) that could be related to the presence of inhibitory substances in milk (Yagi et al., 2004) which are able to affect the performance of the microbial inhibitor tests.

Another important disease related to ectoparasites in caprine livestock is the sarcoptic mange, which often impose severe economic constraints. Among lactone macrolides, 
ivermectin is widely used in livestock to combat this disease because it displays a high efficacy against a wide spectrum of nematode species and many arthropod parasites (McKellar and Benchaoui, 1996). Ivermectin is mainly excreted in faeces, but due to its fat affinity it is also depleted through milk, presenting a very long elimination period in cattle (Alvinerie et al., 1997) and sheep (Cerkvenik et al., 2004; Fernanda et al., 2004). The Maximum Residue Limit (MRL) of ivermectin has been established in Europe (Commission Regulation (EU) No 37/2010) for all mammalian food producing species in fat, liver and kidney $(100,100$ and $30 \mu \mathrm{g} / \mathrm{kg}$, respectively). No MRL for raw milk has been indicated and in the legislation (Commission Regulation (EU) No 37/2010) for ivermectin as provision is specifically noted that it is not for use in animals producing milk for human consumption, so under cascade use in lactating animals is not authorised.

Despite some authors (Imperiale et al., 2004) suggest that in intensive production systems the use of ivermectin in dairy animals could be beneficial for controlling endo- and ectoparasites and should be considered, it would be necessary, however, to assess if the residual amounts of antiparasitic agents in milk pose a risk to the health of the consumers. The results obtained from the study on the illegal administration of ivermectin in lactating goats infested by sarcoptic mange (Chapter 5), showed that ivermectin residues were detected in milk during the fifteen days of the experiment at concentrations between 8.13 and $24.25 \mathrm{ng} / \mathrm{ml}$ reaching the maximum value on the second and third day after the first and second ivermectin administration, respectively. All the microbial inhibitor tests gave some positive results along the experimental period; the most positive results were obtained with the BRT MRL.

The positive results obtained in microbial inhibitor tests in the days after treatment cannot be associated to the ivermectin residues in goat milk as the concentrations in the milk were lower than the inhibitory concentrations reported in a previous in vitro study. Thus, the positive results could be related to other factors and substances due to the parasite infestations and/or by animal reactions on the antiparasitic treatment. Regarding to the alterations and modifications generated by sarcoptic mange in the animal organism, several studies have indicated that this parasitic disease, does not only present visible dermatological symptoms. Thus, it is also associated with physiological changes such as the increased pro-inflammatory cytokine levels in the blood from various skin cells (Arlian et al., 2003; Mullins et al., 2009), high total protein levels, y-globulin and IgG in the serum plasma of chamois (Lastras et al., 2000), and high levels of acute phase proteins (ceruloplasmin, a1acid glycoprotein, haptoglobin, and serum amyloid A) in the blood of mange-infested Alpine ibex (Rahman et al., 2010). 
On the other hand, some antiparasitic drugs, such as ivermectin, have been evaluated as immunomodulators (Stankiewwicz et al., 1995). The potential changes in the immunological system of the animals as a result of the antiparasitic drug activity or by the immune response of the animal to combat the parasitic disease, could result in the presence of inhibitory substances in milk capable of interfering with the test microorganism metabolism, resulting in positive results in microbial tests for screening for antibiotics.

Is important to remark the higher influence to different contaminants in the BRT MRL response compared to the other microbial inhibitor tests used (Chapter 3, 4 and 5). This fact could be associated with the different indicator systems used, BRT MRL employs black brilliant (redox indicator), while Delvotest SP-NT MCS and Eclipse 100 use bromocresol purple ( $\mathrm{pH}$ indicator). Also, there are differences in respect to the culture medium of the tests (BRT MRL uses Mueller Hinton while Delvotest SP-NT MCS and Eclipse 100 use PCA) and other test characteristics ( $\mathrm{pH}$, spores concentration, etc) that could be also related to the different detection capabilities observed by some authors (Sierra et al., 2009a,b; Beltrán et al., 2015) for the detection of antibiotics in goat milk.

In general, by applying codes of good practices in the milk production (FAO and IDF, 2011), the presence of substances potentially interfering (colostrum, detergents, antiparasitic agents, among others) in the microbial test response could be avoided. Thus, if the livestock management practices in regards to the identification of animals, the use of the cleaning products suitable for the milking equipment and refrigerated tanks, as well as the administration of drug treatments to ensure the animal health, are implemented by farmers and veterinarians, the risk of the presence of residues and contaminants in milk can be widely reduced.

On the other hand, the occurrence of false positive results in microbial inhibitor tests have related to some milk physico-chemical characteristics such as gross composition (Carlsson and Björk, 1992; Andrew, 2000; Reybroeck and Ooghe, 2012), natural inhibitors (Carlsson and Björck, 1987; Carlsson and Björck, 1989), fatty acids (Mäyrä-Mäkinen, 1990) or SCC (Cullor et al., 1992; Kang and Kondo, 2001), among others. Also for testing for antibiotics in sheep milk, the same parameters of interference have been published (Althaus et al., 2003; Molina et al., 2003). However, research publications about interferences when testing for antimicrobials in goat milk are hardly existing (Beltrán et al., 2015).

The percentage of false positive results in microbial tests for screening for antibiotics in goat milk (Chapter 6 ) was ranging from 4 to $10 \%$ when the interpretation of the test results was made visually. The occurrence of intermediate colourations in the test agar (green- 
yellow, yellow-blue) after the recommended incubation period, makes an objective classification of the test results more difficult.

The false positive outcomes were associated with elevated $\mathrm{pH}$ values in milk for Delvotest SP-NT MCS. The acid production is used as criterion for bacterial growth in most microbial tests for screening for antibiotics and, therefore, a high $\mathrm{pH}$ value in milk could delay the change in colour of the acid-base indicator affecting the microbial inhibitor test response (Reybroeck, 2010).

Another parameter related with the incidence of false positive outcomes for BRT MRL and Eclipse 100 tests was the high content of fat in the milk. These results are in agreement with Andrew (2000) and Reybroeck and Ooghe (2012), who observed a link between the false positive results in different microbial inhibitor tests for blank cow milk and the high fat content of the milk.

Also, some positive results in microbial inhibitor tests were associated with fatty acids in the milk. For Eclipse 100 butyric acid had a significant effect on the occurrence of positive outcomes. Barbosa (1997) indicated that high level of butyric and capric acid was responsible for positive results when any antibiotic was present in goat milk. In sheep milk, Althaus et al. (2003) did not observed any influence of fatty acids on the response of BRT and Delvotest, although the butyric acid content almost reached statistical significance $(p=$ $0.058)$ to affect the Delvotest result.

Results in this thesis indicate that the positive outcomes in Delvotest SP-NT MCS could be related to myristoleic acid concentration in milk. Kabara et al. (1972) observed that myristoleic acid had an inhibitory effect to Gram-positive microorganisms, and also indicated that unsaturated fatty acids tend to have greater inhibitory potency than saturated fatty acids with the same length of the carbon chain. Feldlaufer et al. (1993) also reported the antibacterial effect of myristoleic acid on Gram-positive bacteria. Geobacillus stearothermophilus var. cadilodactis, the microorganism most used in microbial tests, is Gram-positive, and hence its response could be affected by the presence of this fatty acid.

Regarding to natural inhibitors present in milk, the lactoferrin affected the response of Delvotest SP-NT MCS. Also, Carlsson and Björck (1987) and Carlsson et al. (1989) indicated that the correlation between the high concentrations of lactoferrin and lysozyme in the milk and the presence of false positive results on Delvotest assay. Moreover, Carlsson and Björck (1987) reported the synergistic effect of these natural inhibitors on the test response. 
The use of instrumental devices for the interpretation of the test results allows improving the specificity of microbial screening tests to values up to $99 \%$. Stead et al. (2008) observed in milk from cows that the visual and scanner reading for Delvotest SP-NT in ampoules and multi-plate format gave comparable results. These authors also indicated, that for visual reading clear yellow and purple colours are easy to determine, but the visual assessment of samples with intermediate colours or the presence of a cloud of purple in a yellow background of test medium is more difficult. Also, they suggested that the visual evaluation is subjective by nature, resulting in a slightly higher level of false positive results, which can be reduced by the scanner interpretation.

Another possibility to minimise the incidence of false positive outcomes is the realization of some sample pre-treatments. A significant reduction of positive outcomes in microbial tests was observed by carrying out a heat treatment and/or a fat removal followed by a heat treatment of milk samples. Therefore, these pre-treatments could be included as a routine in the standard operating procedures of the monitoring laboratories in order to decrease the number of false positive results, and thus avoiding problems for goat milk producers and dairy industries.

Some authors also suggested the use of a heat treatment to diminish the number of false positive results on microbial inhibitors tests in milk from different animal species. In cow milk the heat treatment of $82-85^{\circ} \mathrm{C}$ for 5 minutes reduced the positive results by $75 \%$ for Delvotest P (Oliver et al., 1984) and by $85.7 \%$ for Delvotest SP (Kang and Kondo, 2005). However, Molina et al. (1999) obtained a low reduction of doubtful (25\%) and positive (58\%) results for the BRT test by heating the goat milk samples for 10 minutes at $82{ }^{\circ} \mathrm{C}$. Additionally, with the same heat treatment carried out in goat milk samples, Molina et al. (2003) observed a reduction of $100 \%$ for the positive results for BRT and Delvotest in ovine milk, although the doubtful results were reduced by $50 \%$ for BRT and $16.7 \%$ for Delvotest.

Despite the beneficial effect of the heat treatment on the specificity of microbiological screening tests, one should take into account the possible degradation or antimicrobial activity losses of the antibiotic thermolabile substances eventually presents in milk due to the high temperature. In fact, Zorraquino et al. (2008) indicated antimicrobial activity losses in beta-lactam antibiotics ranging from 9 to $35 \%$ in milk samples treated at $83 \stackrel{\circ}{ } \mathrm{C}$ for 10 minutes. On the other hand, although related studies are non-existent, the effect of the milk fat removal on the detection of antibiotic substances with a lipophilic character should also be considered. 
The establishment of appropriate operational procedures in the control of the presence of antibiotics in raw goat milk is crucial to avoid the problems associated with the presence of false positive results, contributing to limit the losses due to discarded milk and dairy products or additional confirmatory analysis costs.

\section{References}

Airlan, L.G., Morgan, M.S., Neal, J.S. 2003. Modulation of cytokine expresión in human keratinocytes and fibroblasts by extracts of scabies mites. Am. J. Trop. Med. 69: 652656.

Althaus, R.L., Torres, A., Torres, A., Peris, C., Beltrán, M.C., Fernández, N., Molina, M.P. 2003. Accuracy of BRT and Delvotest microbial inhibition tests as affected by composition of ewe's milk. J. Food Protect. 66: 473-478.

Alvineire, M. 1997. Comparative pharmacokinetic properties of moxidectin and ivermectina in different animal species. J. Vet. Pharmacol. Ther. 20: 74.

Andrew, S. M. 2000. Effect of fat and protein content of milk from individual cows on the specificity rates of antibiotic residue screening tests. J. Dairy Sci. 83: 2992-2997.

Andrew, S.M. 2001. Effect of composition of colostrum and transition milk from Holstein heifers on specificity rates of antibiotic residue tests. J. Dairy Sci. 84: 100-106.

Argüello, A., Castro N., Capote J. 2004. Growth of milk replacer kids fed under three different managements. J. Appl. Anim. Res. 25: 37-40.

Argüello, A., Castro, N., Álvarez, S., Capote C. 2006. Effects of the number of lactations and litter size on chemical composition and physical characteristics of goat colostrum. Small Rumin. Res. 64: 53-59.

Barbosa, M. 1997. Occurrence of antibiotics in ewe and goat milk. Application and suitability of various test kits. Anex IV. Report. Analytical Week. Lisboa, Portugal.

Beltrán, M.C., Berruga, M.I., Molina, A., Althaus, R.L., Molina M.P. 2015. Performance of the current microbial tests for screening antibiotic in sheep and goat Milk. Int. Dairy J. 41: 1315.

Campbell, W. 1990. Benzimidazole: veterinary uses. Parasitol. Today. 6: 130-133.

Carlsson, Å., Björk, L. 1987. The effect of some indigenous antibacterial factors in milk on the growth of Bacillus stearothermophilus var. calidolactis. Milchwissenschaft 42: 283285. 
Carlsson, Å., Björk, L. 1992. Liquid chromatography verification of tetraciclyne residues in milk and infkuence of milk fat lipolysis on the detection of antibiotic residues by microbial assays and the Charm II test. J. Food. Prot. 55: 374-378.

Carlsson, Å., Björk, L., Persson, K. 1989. Lactoferrin and lysozyme in milk during acute mastitis and their inhibitory effect in Delvotest P. J. Dairy Sci. 72: 3166-3175.

Cerkvenik, V., Bogdan, B., Rogeli, I., Doganoc, D., Skubic, V., Beek, W. 2004. Fate of ivermectin residues in milk and derived products. J. Dairy Res. 71: 39-45.

Cinquina, A., Longo, F., Raponi, A., Bocsa, A., Cozani, R. 1997. Pharmacokinetic albendazole metabolites in goat milk and milk products. Ital. J. Food Sci. 9: 231-237.

Commission Decision 2002/657/EC of 12 August 2002 implementing Council Directive $96 / 23 / E C$ concerning the performance of analytical methods and the interpretation of results. Off. J. Eur. Comm. 2002 L221: 8-36.

Commission Regulation (EU) No 37/2010 of 22 December 2009 on pharmacologically active substances and their classification regarding maximum residue limits in foodstuffs of animal origin. Off. J. Eur. Union 2009 L15: 1-72.

Cullor, J. S. 1992. Test for identifying antibiotic residues in milk:how well do they work? Vet. Med. 87: 1235-1241.

Danaher, M., De Ruyck, H., Crooks, S.R.H., Dowling, G., O'Keeffe, M. 2007. Review of methodology for the determination of benzimidazole residues in biological matrices. $\mathrm{J}$. Chromatogr. B. 845: 1-37.

Directive 2001/82/EC of the European Parliament and of the council of 6 november 2001on the community code relating to veterinary medicinal products. Off. J. Eur. Comm 2001L311: 1-66.

Directive 2004/28/EC of the European Parliament and of the council of 31 march 2004 amending directive $2001 / 82 / E C$ on the community code relating to veterinary medicinal products, Off. J. Eur. Comm 2004 L136: 58-84.

Demoly, P., Romano, A. 2005. Update on beta-lactam allergy diagnosis. Curr. Allergy Asthm. R. 5: 9-14.

Dunsmore, D.G., Makin, D., Arkin R. 1985 Effect of residues of five disinfectants in milk on acid production by strains of lactic starters used for Cheddar cheese making and on organoleptic properties of the cheese. J. Dairy Res. 52: 287-297. 
Egan, J., Meaney, W.J. 1984. The inhibitory effect of mastitic milk and colostrums on test methods used for antibiotic detection. Ir. J. Food Sci. 8: 115-120.

Fabre, J.M., Moretain, J.P., Ascher, F., Brouillet, O., Berthelot, X. 1995. Main causes of inhibitors in milk. A survey in one thousand French dairy farms. In: Residues of Antimicrobial Drugs and other Inhibitors in Milk. IDF S.I. 9505: 27-31. International Dairy Federation, Brussels Belgium.

FAO and IDF. 2011. Guide to good dairy farming practice. Animal Production and Health Guidelines. No. 8. Rome, Italy.

Feldlaufer, M.F., Knox, D.A., Lusby, W.R., Shimanuki, H. 1993. Antimicrobial activity of fatty acids against Bacillus larvae, the causative agent of America foulbrood disease. Apidologie. 24: 95-99.

Fernanda, A., Imperiale, F., Margarita, R., Lanusse, E. 2004. Milk excretion of ivermectin and moxidectin in dairy sheep cheese elaboration. Food Chem. 52: 6205-6211.

Fthenakis, G. C., Papadopulos, E., Himonas, C., Leontide, L., Kritas, S., Papatsas, J. 2000. Efficacy of moxidectin against sarcoptic mange and effects on milk yield of ewes and growth of lambs. Vet. Parasitol. 87: 207-216.

Fox, L.K., Hancock, D.D., Horner, S.D. 1992. Selective intramamary antibiotic therapy during the nonlactating period in goats. Small Rumin. Res. 9: 313-318.

González-Canga, A., Belmar-Liberato, R., Escribano, M. 2012. Extra-label use of ivermectine in some minor ruminant species: pharmacokinetic aspects. Curr. Pharm. Biotechnol. 13: 924-935.

Guirguis, N., Hickey, M.W. 1987. Factors affecting the performance of thermophilic starters. I. Sensitivity to dairy sanitizers. II. Sensitivity to the lactoperoxidase system. Aust. J. Dairy Technol. 42:11-26.

Hiss, S., Meyer, T., Sauerwein, H. 2008. Lactoferrin concentrations in goat milk throughout lactation. Small Rumin. Res. 80: 87-90.

Imperiale, F., Lifschitz, A., Sallovitz, J., Virkel, G., Lanusse, C. 2004. Comparative depletion of ivermectina and moxidectin milk residues in dairy sheep after oral and subcutaneous administration. J. Dairy Res. 71: 427-433.

Kabara, J.J., Swieczkwoski, D.M., Conley, A.J., Truant, J.P. 1972. Fatty acids and derivatives as antimicrobial agents. Antimicrob. Agents Chemother. 2: 23-28. 
Kang, J.H., Kondo, F. 2001. Occurrence of false-positive results of inhibitor on milk samples using the Delvotest SP assay. J. Food Prot. 64: 1211-121Kemper N. 2008. Review: Veterinary antibiotics in the aquatic and terrestrial environment. Ecological indicators. 8: $1-13$.

Kang, J.H., Jin, J.H., Kondo, F. 2005. False-positive outcome and drug residue in milk samples over withdrawal times. J. Dairy Sci. 88: 908-913.

Lastras, M.E., Pastor, J., Marco, I., Ruiz, M., Viñas, L., Lavin, S. 2000. Effects of sarcoptic mange on serum proteins and immunoglobulin $G$ levels in chamois (Rupicabra pyrenaica) and Spanish ibex (Capra pyrenaica). Vet. Parasitol. 88:131-319.

Lezzi, S., Lifschitz, A., Sallovitz, J., Nejamkin, P., Lloberas, M., Manazza, J. 2014. Closantel plasma and milk disposition in dairy goats: assessment of drug residues in cheese and ricotta. J. Vet. $\quad$ Pharmacol. http://onlinelibrary.wiley.com/doi/10.1111/jvp.12135/pdf

Lohuis, J.A.C.M., Poutrel, B., de Cremoux, R., Parez, V., Aguer, D. 1995. Milk residues of penicillin, nafcillin and dihydrostreptomycin in dairy goats postpartum treated with nafpenzal N8[R] at drying-off. pp. 102-103. In: Session 5: treatment of mastitis, Proceedings of the 3rd International Mastitis Seminar, IDF, Ed. A. Saran and S. Soback, May 28 - June 1, Tel Aviv, Israel.

Mäyrä-Mäkinen, A. 1990. T-101 test for antibiotic residues in milk. Scand. Dairy Inf. 2: 38-39.

McKellar, Q.A., Benchaoui, H.A. 1996. Avermectins and milbemycins. J. Vet. Pharmacol. Ther. 19: 331-351.

Merin, U., Rosenthal, I., Bernstein, S., Popel, G. 1985. The effect of residues of detergents and detergents-sanitizers on the performance of antibiotic test and the organoleptic quality of milk. Le Lait. 65: 163-167.

Mullins, J.S., Arlian, L.G., Morgan M.S. 2009. Extracts of Sarcoptes scabiei De Geer down modulate secretion of IL-8 by skin keratinocytes and fibroblasts and of GM-CSF by fibroblasts in presence of proinflamatory cytokines. J. Med. Entomol. 46: 845-851.

Molina, M.P., Segura, C., Luján, A., Althaus, R.L., Peris, C. 1999. Influencia del calentamiento y del tiempo de incubación sobre la respuesta del método BRT en la leche de cabra. Ile, Revista Mensual de las Industrias Lácteas Españolas. 241: 37-40. 
Molina, M.P., Althaus, R.L., Balasch, S., Torres, A., Peris, C., Fernandez, N. 2003. Evaluation of screening test for detection of antimicrobial residues in ewe milk. J. Dairy Sci. 86: 1947-1952.

Oh, D.H., Marshall, D.L. 1993 Antimicrobial activity of ethanol, glycerol monolaurate of lactic acid against Listeria monocytogenes. Int. J. Food Microbiol. 20: 239-246.

Oliver, S.P., Duby, R.T., Prange, R. W., Tritschler, J. P. 1984. Residues in colostrum following antibiotic dry cow therapy. J. Dairy Sci. 67: 3081-3084.

Packham, W., Broome, M.C., Limsowtin, G.K.Y., Roginski, H. 2001. Limitations of standard antibiotic screening assays when applied to milk for cheesemaking. Aust. J. Dairy Technol. 56: 15-18.

Petrova, N., Dimitrov, N. 1993. Effect of alkaline combined agents on the activity of the bacteria starter (Lactococcus lactis and Lactobacillus casei L116-40) used for manufacturing white brined cheese from ewe's milk. Food Res. Int. 26: 327-332.

Pontefract, R.D. 1991. Bacterial adherence: its consequences in food processing. Can. I. Food Sci. Tech. J. 24: 113-117.

Rahman, M., Lecchi, C., Fraquelli, C., Sartorelli, P., Ceciliani, F. 2010. Acute phase protein response in Alpine ibex with sarcoptic mange. Vet. Parasitol. 168: 293-298.

Reinemann, D.J., Wolters, G.M.V.H., Billon, P., Lind, O., Rasmussen, M.D. 2003. Review of practices for cleaning and sanitation of milking machines. IDF Bull 381:32-50. International Dairy Federation, Brussels, Belgium.

Regulation (EC) No 853/2004 of the European Parliament and of the Council of 29 April 2004 laying down specific hygiene rules for on the hygiene of foodstuffs. Off. J. Eur. Union 2004 L139: 55-05.

Reybroeck, W. 1997. Detergents and disinfectants. In Residues and Contaminants in Milk and Milk Products, Vol. 9701, pp. 109-119. Brussels, Belgium: International Dairy Federation.

Reybroeck, W. 2010. Screening for residues of antibiotics and chemotherapeutics in milk and honey. Thesis submitted in fulfillment of the requirements for the degree of Doctor (Ph.D.) in Veterinary Sciences, Faculty of Veterinary Medicine, Ghent University: 1-295. ISBN 978-90-5864-244-8.

Reybroeck, W., Ooghe, S. 2012. FASFC acceptance criteria for microbiological inhibitor tests: fulfillment by new tests. pp 197-201. In: Schilt R, editor. Proceedings of the 
EuroResidue VII Conference on residues of veterinary drugs in food, Egmond aan Zee, The Netherlands, May 14-16.

Romero, T., Beltrán, M.C., Rodríguez, M., Martí De Olives, A., Molina, M.P. 2013. Short communication: Goat colostrum quality: Litter size and lactation number effects. J. Dairy Sci. 96: 7526-7531.

Sajid, M.S., Muhammad, G., Iqbal, M.U. 2006. Immunomodulatory effect of various antiparasitics: a review. Parasitology. 132: 301-313.

Salomskiene, J., Macioniene, I., Zvirdauskiene, R., Jonkuviene, D. 2013. Impact of the residues of detergents and disinfectants used in dairy farms on the results of inhibitor tests for raw mik. Adv. Biosci. Biotechnol. 4: 266-277.

Sanders, P., Bousquet-Melou, A., Chauvin, C., Toutain, P.L. 2011. Utilisation des antibiotiques en élevage et enjeux de santé publique (Use of antibiotics in animal and public health issues). INRA Prod. Anim. 24: 199-204.

Scott, E.W., Kinabo, L.D., McKellar, Q.A. 1990. Pharmacokinetics of ivermectina after oral or percutaneous administration to adult milking goats. J. Vet. Pharmacol. Ther.13: 432-435.

Schiffmann, A.P., Schütz, M., Wiesner, H. 1992. False negative and positive results in testing for inhibitory substances in milk. Factors influencing the brilliant black reduction test (BRT). Milchwissenschaft. 47: 770-772.

Sierra, D., Sánchez, A., Contreras, A., Luengo, C., Corrales, J.C., de la Fe, C., Guirao, I., Morales, C.T., Gonzalo, C. 2009a. Detection limits of four antimicrobial residue screening test for $\beta$-lactams in goat's milk. J. Dairy Sci. 92: 3585-3591.

Sierra, D., Contreras, A., Sánchez, A., Luengo, C., Corrales, J.C., Morales, C.T., De la Fe, C., Guirao, I., Gonzalo, C. 2009b. Short communication: Detection limits of non- $\beta$-lactam antibiotics in goat's milk by microbiological residues screening tests. J. Dairy Sci. 92: 4200-4206.

Stankiewicz, M., Cabaj, W., Jonas, W.E., Moore, L.G., Millar, K., Chie, W. 1995. Influence of ivermectina on cellular and humoral immune responses of lambs. Vet. Immunol. Immunopathol. 44: 347-358.

Stead, S.L., Ashwin, H., Richmond, S.F., Sharman, M., Langeveld P.C., Barendse, J.P., Stark, J., Keely, B.J. 2008. Evaluation and validation according to international standards of the Delvotest SP-NT screening assay for antimicrobial drugs in milk. Int. Dairy J. 18: 311. 
Tizard, I.R. 2009. Drugs and other agents that affect the immune system. pp. 487-488. In: Veterinary immunology: an introduction. 8th Ed. St Louis, Mo. Saunders Elsevier.

Trevisi, E., Bertoni, G. 2009. Some physiological and biochemical methods for acute and chronic stress evaluation in dairy cows. Ital. J. Anim. Sci. 8: 265-286.

Trobos, M., Lester, C.H., Olsen, J.E., Frimodt-Moller, N., Hammerum, A.M. 2009. Natural transfer of sulphonamide and ampicillin resistance between Escherichia coli residing in the human intestine. J. Antimicrob. Chemother. 63: 80-86.

Waldhalm, S.J., Criss, E.A., Neff-Davis, C.A., Huber, W.G. 1989. Febendazole clearance from goat milk. Small Rumin. Res. 2: 79-84.

Walton, S.F., Currie, B.J. 2007. Problems in diagnosing scabies, a global disease in human and animal population. Clin. Microbiol. Rev. 20: 268-279.

Yagi, Y., Shiono, H., Chikayama, Y., Ohnuma, A., Nakamura, I., Yayou, K.I. 2004. Transport stress increase somatic cell in milk, and enhances the migration capacity of peripheral blood neutrophils of dairy cows. J. Vet. Med. Sci. 66: 381-387.

Zorraquino, M.A., Roca, M., Fernández, N., Molina, M.P., Althaus, R.L. 2008. Heat inactivation of $\beta$-lactam antibiotic in milk. J. Food Prot. 71: 1193-1198.

Zvirdauskiene, R., Salomskiene, J. 2007. An evaluation of different microbial and rapid test for determining inhibitors in milk. Food Control. 18: 541-547. 



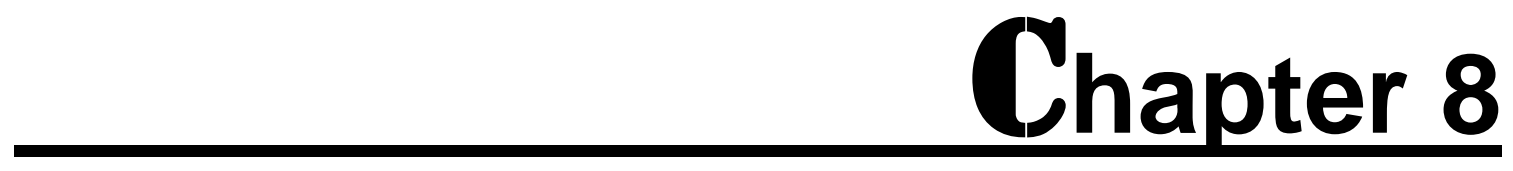

General conclusions 



\section{General Conclusions}

This thesis is focused on the study of the effect of different residues and/or contaminants in goat milk derived from farming practices, as well as the characteristics of the goat milk itself, on the results of the microbial tests for screening antibiotics BRT MRL, Delvotest SPNT MCS and Eclipse 100. The conclusions drawn from this research are then exposed:

- Microbial tests to detect inhibitors in milk are not suitable for monitoring the presence of antibiotic residues in goat colostrum, since a high percentage of false positive results in secretions until 48 hours post-partum was obtained mainly related to the high protein content. In addition, the presence of colostrum from 12-24 hours post-partum in goat milk may cause false positive results in microbial tests being the BRT MRL response the most affected.

- The presence of acid detergents or disinfectants based on sodium hypochlorite in goat milk did not affect the microbial test response. However, alkaline detergents and domestic washing-up liquids containing sodium laureth sulphate and ethanol reaching concentrations $\geq 1 \mathrm{ml} / /$ could lead to false positive results. Moreover, the microbial test detection capability for amoxicillin, ampicillin, benzylpenicillin and cloxacillin was slightly modified by the presence of detergents in goat milk at low concentration $(0.5 \mathrm{ml} / \mathrm{l})$, however, the detection of these drugs at safe level (MRL) was not compromised.

- In general, the "in vitro" addition of the antiparasitic agents to goat milk causes the occurrence of positive results in microbial tests when very high concentrations are present. The BRT MRL was the most sensitive to these substances showing the lower inhibitory concentration responsible for producing 5,10 and $50 \%$ of false positive results respect to other tests.

- After oral administration of albendazol in dairy goats, drug residues were not detected in goat milk from the third day after treatment. However, unlike the other two tests, the BRT MRL showed positive outcomes along the six days after drug administration, suggesting that these interferences could be associated with factors related to the veterinary treatment rather than to the presence of albendazol metabolites in goat milk.

- The subcutaneous unauthorised treatment of ivermectin in lactating goats infested with Sarcoptes scabiei, results in drug residues in milk at least for fifteen days post-treatment. All microbial inhibitor tests presented positive results for some days, the longest period 
for the BRT MRL but the positive results cannot be related to the ivermectin residues in milk which were lower than the inhibitory concentrations calculated in the in vitro study. A possible explanation for these interferences might be changes caused by the application of parasiticide agents or by the parasitic disease itself on the immune response of goats.

- The specificity of microbial inhibitor tests in raw goat milk free of antimicrobials was higher when the classification of the test results was carried out instrumentally than visually. The false positive outcomes obtained in each microbial test were associated with some goat milk characteristics. BRT MRL and Eclipse 100 responses were affected by a high fat content. Butyric acid was also related to positive results in Eclipse100. For Delvotest SP-NT MCS the positive outcomes were correlated to high $\mathrm{pH}$ values and elevated myristoleic acid and lactoferrin contents. False positive results could be reduced by making some sample treatments such as fat removal and/or heat treatment prior to the analysis by microbial tests.

The conclusions of this thesis involve increase the knowledge on the causes of positive results in microbial screening tests that cause serious problems for farmers and dairy industries, as well as milk control laboratories. The rejection of good quality milk due to false positive results in microbial inhibitor test should be avoided as much as possible. Therefore, the application of good farming practices in dairy goat livestock is essential to limit the presence of residues and contaminants in milk and to preserve the animals' health. Monitoring the presence of antibiotic residues in milk is a crucial aspect to guarantee the safety of dairy products. 
List of Publications 



\section{List of publications derived from this thesis}

\section{- Preer-reviewed scientific papers}

Romero, T., Beltrán, M.C., Pérez-Baena, I., Rodríguez, M., Molina, M.P. 2014. Effect of the presence of colostrum on microbial screening methods for antibiotic detection in goats' milk. Small Rumin. Res. 121: 376-381.

Romero, T., Beltrán, M.C., Althaus, R.L., Molina, M.P. 2014. Detection of antibiotics in goat's milk: effect of detergents on the response of microbial inhibitor tests. J. Dairy Res. 81: 372-377.

Romero, T., Beltrán, M.C., Molina, M.P. 2014. Interference of cleaning products for home use in goat milk on microbial inhibitor tests for screening for antibiotics. Submitted to J. Appl. Anim. Res.

Romero, T., Beltrán, M.C., Reybroeck, W., Molina, M.P. 2014. Antiparasitic drugs in goat milk: in vitro effect on the response of microbial tests for screening antibiotic residues. Submitted to J. Food Prot.

Romero, T., Althaus, R.L., Moya, V.J., Beltrán, M.C., Reybroeck, W., Molina, M.P. 2014. Albendazole residues in goat milk. Interferences on microbial inhibitor tests. Submitted to Czech J. Food Sci.

Romero, T., Moya, V.J., Fernández, N., Althaus, R.L., Reybroeck, W., Molina, M.P. 2014. Interferences on microbial inhibitor tests related to ivermectin treatment in dairy goats. Submitted to J. Dairy Res.

\section{- $\quad$ International and National Congress}

Romero, T., Van Weyenberg, S., Molina, M.P., Reybroeck, W. 2014. Impact of the composition and quality of goats' milk on the response of commercial inhibitor tests. 7 th International Symposium on Hormone and Veterinary Drug Residue Analysis. June 2-5, Ghent, Belgium.

Romero, T.; Reybroeck, W. 2014. Effect of fatty acids in goats' milk on the response of microbial inhibitor tests. 7 th International Symposium on Hormone and Veterinary Drug Residue Analysis. June 2-5, Ghent, Belgium.

Romero T., Beltrán, M.C., Althaus, R.L., Molina, M.P. 2012. Efecto de sustancias antiparasitarias en leche de cabra sobre los metodos microbiológicos de detección de 
inhibidores. XXXVII Congreso Nacional y XII Internacional Sociedad de la Española de Ovinotecnia y Caprinotecnia (SEOC). September 19-21, Ciudad Real, Sapin.

Beltrán, M.C., Romero, T., Nagel, O.G., Althaus, R.L., Molina, M.P. 2012. Effect of detergent residues in goat's milk on the response of screening methods for antibiotic detection. IDF International Symposium on Sheep, Goat and Other Non-cow Milk. May 16-18, Athenes, Greece.

\section{List of publications related with this thesis}

- $\quad$ Preer-reviewed scientific papers

Romero, T., Beltrán, M.C., Marti-De Olives, A., Rodríguez, M., Molina, M.P. 2013. Goat colostrum quality. litter size and lactation number effects. J. Dairy Sci. 96: 7526-7531.

Pérez-Baena, I., Blasco, E., Sánchez-Quinche, A., Romero, T., Mazón, J., Peris, C. 2012. Efecto de la sarna sobre la producción y la composición de la leche de cabras. Albéitar. 158: 10-11.

- International and National Congress

Romero, T., Pérez-Baena, I., Beltrán, M.C., Molina, M.P. 2014. Efecto del antiparasitario diazinón sobre la presencia de inhibidores en leche de cabra. XXXIX Congreso Nacional y XV Internacional de la Sociedad Española de Ovinotecnia y Caprinotecnia (SEOC). September 17-19, Ourense, Spain.

Romero, T., Beltrán, M.C., Balado, M., J.; Althaus, R.L., Molina, M.P. 2013. Effect of prophylactic use of antibiotics in intravaginal sponges on the response of inhibitor screening tests in goats milk. Joint ADSA-ASAS Annual Meeting. July 8-12, Indianapolis, Indiana.

Romero, T., Beltrán, M.C., Rodríguez, M., Martí-De Olives, A., Molina, M.P. 2012. Physical characteristics and chemical composition of murciano-granadina goat's colostrum. XI international conference on goat (IGA). September 24-27, Las Palmas de Gran Canaria, Spain.

Romero, T.; Beltrán, M.C.; Mata, L.; Molina, M.P. 2011. Determinación del contenido en inmunoglobulinas $\mathrm{G}$ del calostro y la leche de cabras murciano-granadinas. XXXVI Congreso Nacional de la Sociedad Española de Ovinotecnia y Caprinotecnia (SEOC). October 6-7, Donostia-San Sebastián, Spain. 

